Issued by Sandia National Laboratories, operated for the United States Department of Energy by Sandia Corporation.

NOTICE: This report was prepared as an account of work sponsored by an agency of the United States Government. Neither the United States Government, nor any agency thereof, nor any of their employees, nor any of their contractors, subcontractors, or their employees, make any warranty, express or implied, or assume any legal liability or responsibility for the accuracy, completeness, or usefulness of any information, apparatus, product, or process disclosed, or represent that its use would not infringe privately owned rights. Reference herein to any specific commercial product, process, or service by trade name, trademark, manufacturer, or otherwise, does not necessarily constitute or imply its endorsement, recommendation, or favoring by the United States Government, any agency thereof, or any of their contractors or subcontractors. The views and opinions expressed herein do not necessarily state or reflect those of the United States Government, any agency thereof, or any of their contractors.

Printed in the United States of America. This report has been reproduced directly from the best available copy.

Available to DOE and DOE contractors from Office of Scientific and Technical Information P.O. Box 62

Oak Ridge, TN 37831

Prices available from (703) 605-6000

Web site: http://www.ntis.gov/ordering.htm

Available to the public from National Technical Information Service U.S. Department of Commerce 5285 Port Royal Rd

Springfield, VA 22161

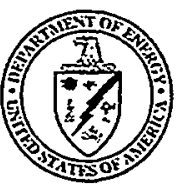




\section{DISCLAIMER}

Portions of this document may be illegible in electronic image products. Images are produced from the best available original document. 
SAND99-3005

Unlimited Release

Printed December 1999

\title{
Preliminary Safety Analysis Report for the Auxiliary Hot Cell Facility, Sandia National Laboratories, Albuquerque, New Mexico
}

\author{
Debby S. Oscar, Sharon A. Walker \\ Nuclear Facility Support Department \\ Regina L. Hunter \\ Environmental Systems Department \\ John Garcia \\ Reactor Safety Experiments Department \\ Sandia National Laboratories \\ P.O. Box 5800 \\ Albuquerque, NM 87185-0716 \\ Cheryl A. Walker \\ TechEdits, Albuquerque, NM
}

\begin{abstract}
The Auxiliary Hot Cell Facility (AHCF) at Sandia National Laboratories, New Mexico (SNL/NM) will be a Hazard Category 3 nuclear facility used to characterize, treat, and repackage radioactive and mixed material and waste for reuse, recycling, or ultimate disposal. A significant upgrade to a previous facility, the Temporary Hot Cell, will be implemented to perform this mission. The following major features will be added: a permanent shield wall; eight floor silos; new roof portals in the hot-cell roof; an upgraded ventilation system; an upgraded hot-cell jib crane; and video cameras to record operations and facilitate remote-handled operations. No safety-class systems, structures, and components will be present in the AHCF. There will be five safety-significant SSCs: hot cell structure, permanent shield wall, shield plugs, ventilation system, and HEPA filters. The type and quantity of radionuclides that could be located in the AHCF are defined primarily by SNL/NM's legacy materials, which include radioactive, transuranic, and mixed waste.

The risk to the public or the environment presented by the AHCF is minor due to the inventory limitations of the Hazard Category 3 classification. Potential doses at the exclusion boundary are well below the evaluation guidelines of $25 \mathrm{rem}$. Potential for worker exposure is limited by the passive design features incorporated in the AHCF and by SNL's radiation protection program. There is no potential for exposure of the public to chemical hazards above the Emergency Response Protection Guidelines Level 2.
\end{abstract}




\section{ACKNOWLEDGMENTS}

Dennis A. Nelson, Jr., contributed to the development of Chapter 4. Ron Lipinski, Henry Duong, and Wu-Ching Cheng contributed to the sections on waste characterization. A facility engineering team led by Paul Schlavin led the design effort and provided design information for Chapter 2. The members of the Radiological and Criticality Safety Committee (RCSC), Nuclear Facility Safety Committee (NFSC), and the review committee led by Liz Roybal for the Department of Energy Albuquerque Operations Office made numerous helpful technical and editorial comments. Ken Reil, Norm Schwers, and Jeff Mahn, provided detailed review on several versions of the manuscript. Figure 2-7 was provided by Merrick Engineers \& Architects, who was the contractor developing the design from SNL design requirements. Nancy Nalda of Technadyne Engineering Consultants and Caroline Souza, SNL, assisted in preparing the manuscript.

Work on the PSAR was sponsored by the Radioactive Waste/Nuclear Materials Disposition Department, under the leadership of Earl Conway. 


\section{CONTENTS}

PAGE

1 SITE CHARACTERISTICS ....................................................................... 1-1

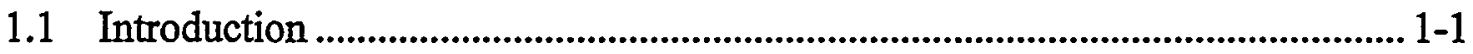

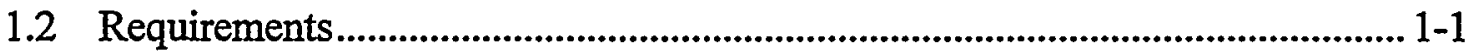

1.3. Site Description .................................................................................................... 1-1

1.3.1 Geography............................................................................................. 1-2

1.3.1.1 SNL/NM Site Description.......................................................... 1-2

1.3.1.2 TA-V Site Description ............................................................... 1-2

1.3.1.3 AHCF Site Description............................................................. 1-6

1.3.1.4 Public Exclusion Areas ........................................................ 1-6

1.3.1.5 Access Control ...................................................................... 1-6

1.3.1.6 Point Where Evaluation Guidelines Are Applied...................... 1-7

1.3.2 Demography ................................................................................ 1-7

1.3.2.1 Albuquerque and Surrounding Area Demography .................... 1-7

1.3.2.2 Demography for KAFB and TAs Surrounding TA-V .............. 1-9

1.3.2.3 TA-V Demography ........................................................ 1-10

1.4 Environmental Description........................................................................... 1-10

1.4.1 Meteorology ............................................................................................. 1-10

1.4.1.1 General Regional Climatology and Local Meteorology .......... 1-10

1.4.1.2 Temperature, Humidity, and Precipitation................................ 1-11

1.4.1.3 Meteorological Measurement and Monitoring Program.......... 1-12

1.4.1.4 Local Transport and Dispersion................................................ 1-15

1.4.1.5 Meteorological Data for Accident Release ............................. 1-17

1.4.2 Hydrology ....................................................................................... 1-17

1.4.2.1 Surface Drainage........................................................................ 1-17

1.4.2.2 Soil Characteristics .................................................................... 1-18

1.4.2.3 Subsurface Characteristics....................................................... 1-19

1.4.2.4 TA-V Water Supply ............................................................. 1-21

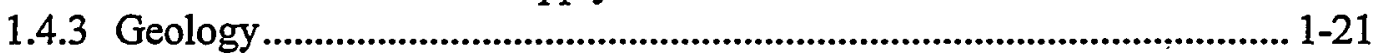

1.4.3.1 General Data ..................................................................... 1-21

1.4.3.2 Basin and Range Structures .................................................... 1-23

1.4.3.3 Site Geology........................................................................... 1-23

1.5 Natural Hazards .................................................................................... 1-24

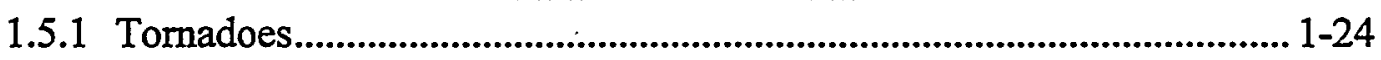

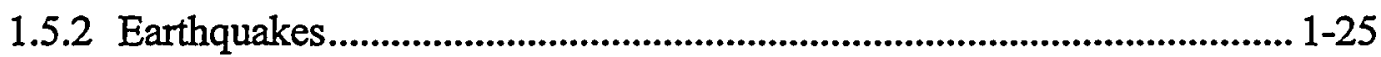

1.5.2.1 Seismic History ............................................................. 1-25

1.5.2.2 Albuquerque Fault Zones.................................................... 1-27

1.5.2.3 Fault Zones in the Vicinity of TA-V.................................... 1-27

1.5.3 Flooding .................................................................................... 1-30

1.6 External Manmade Threats ........................................................................ 1-30

1.7 Nearby Facilities................................................................................ 1-30

1.8 Validity Of Existing Environmental Analyses.................................................. 1-31

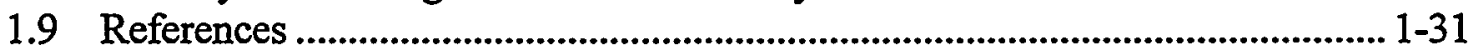


2 FACILITIES DESCRIPTION ............................................................................. 2-1

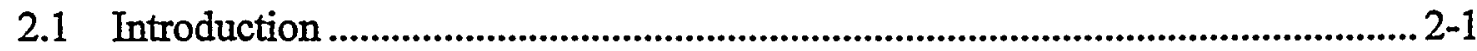

2.2 Requirements............................................................................................... 2-1

2.2.1 DOE Orders and Standards, Laws, and Regulations .................................. 2-1

2.2.2 Industry Codes and Standards............................................................. 2-2

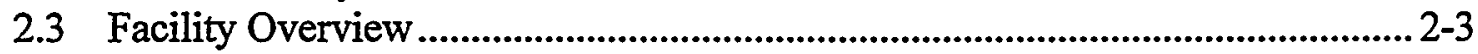

2.3.1 Historical and Current Use of Building 6597 High Bay .......................... 2-3

2.3.2 Projected Use of Facility ............................................................................. 2-3

2.3.3 Basic Configuration of Building 6597 ......................................................2-4

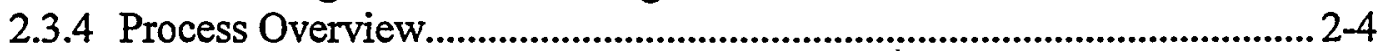

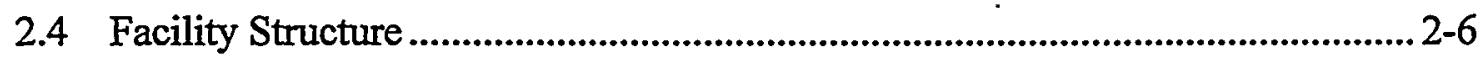

2.4.1 Auxiliary Hot Cell Facility .................................................................... 2-6

2.4.1.1 Basic Floor Plan and Layout of Equipment and Structures...... 2-7

2.4.1.2 Building 6597 Structural and Mechanical Components ............ 2-9

2.4.2 AHCF Structural and Mechanical Components .................................... 2-10

2.4.2.1 Hot Cell ................................................................................. 2-11

2.4.2.2 Fume Hood........................................................................ 2-15

2.4.2.3 Shield Walls........................................................................2-16

2.4.2.4 Temporary Room ........................................................... 2-16

2.4.2.5 Shield Plugs ...................................................................... 2-16

2.5 Process Description .................................................................................. 2-17

2.5.1 Types and Quantities of Materials and Radioactive and

Mixed Waste .................................................................................... 2-17

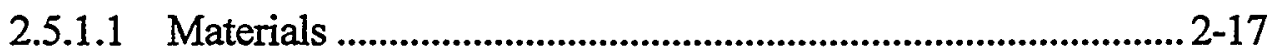

2.5.1.2 Radioactive and Mixed Waste ................................................ 2-17

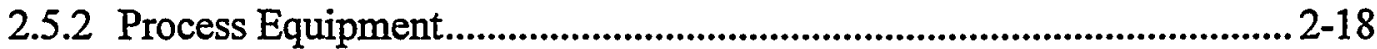

2.5.2.1 Trucks and Forklifts........................................................2-18

2.5.2.2 Building 6597 Bridge Cranes..............................................2-18

2.5.2.3 Hot Cell Jib Crane............................................................ 2-19

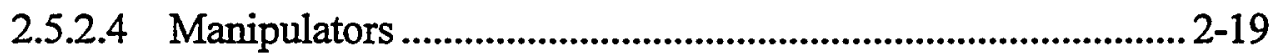

2.5.2.5 Building and AHCF Cameras .............................................. 2-19

2.5.2.6 Gamma Scanner............................................................ 2-21

2.5.3 Instrumentation and Control Systems and Equipment............................2-21

2.5.4 Basic Process and Flow Diagram ........................................................... 2-21

2.5.4.1 Materials and Radioactive and Mixed-Waste Processing at the Fume Hood ................................................. 2-24

2.5.4.2 Materials and Radioactive and Mixed-Waste Processing in the Hot Cell.......................................................2-24

2.5.4.3 Materials and Radioactive and Mixed-Waste Processing behind the Permanent Shield Wall and in the Temporary Room .....................................................2-25

2.5.4.4 Post-Characterization Process..............................................2-2-26

2.5.5 Operational Considerations............................................................ 2-26

2.5.6 Process/Design Safety Features ........................................................ 2-27

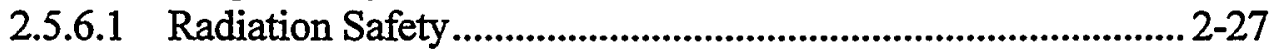

2.5.6.2 Criticality Safety ................................................................. 2-28 


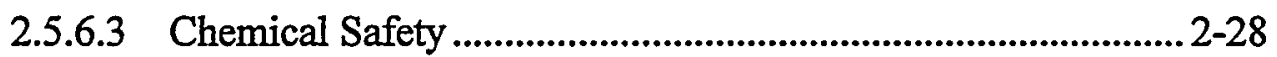

2.5.6.4 Process Equipment Safety.................................................2-28

2.6 Confinement Systems....................................................................................... 2-29

2.6.1 Hot Cell Confinement ...................................................................2-29

2.6.2 Materials/Waste Container Confinement.............................................. 2-29

2.6.3 Fume Hood Confinement................................................................. 2-30

2.6.4 Ventilation/Filtration System Confinement.......................................... 2-30

2.7 Safety Support Systems................................................................................... 2-32

2.7.1 Fire Protection................................................................................... 2-33

2.7.1.1 Building Fire Protection........................................................... 2-33

2.7.1.2 Hot Cell Fire Protection........................................................... 2-33

2.7.2 Criticality Monitoring ........................................................................... 2-35

2.7.3 Radiological Monitoring ................................................................2-35

2.7.3.1 Contamination Prevention ..................................................2-36

2.7.3.2 Air Monitoring ..................................................................... 2-36

2.7.4 Chemical Monitoring ............................................................................. 2-36

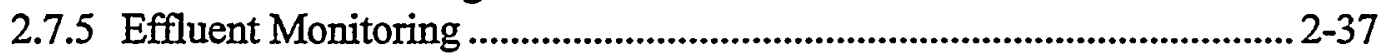

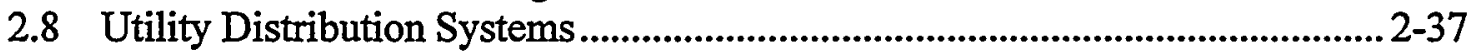

2.8.1 Power and Light.................................................................................... 2-37

2.8.1.1 Building 6597 Power and Light.............................................2-37

2.8.1.2 Auxiliary Hot Cell Facility Power and Light.......................... 2-38

2.8.2 Domestic and Process Water ............................................................. 2-39

2.9 Auxiliary Systems and Support Facilities ......................................................... 2-39

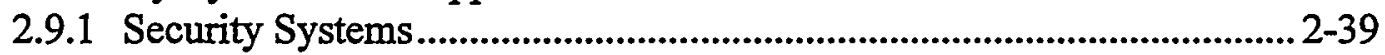

2.9.2 Communication Systems ...................................................................... 2-40

2.9.3 Medical Support........................................................................................ 2-40

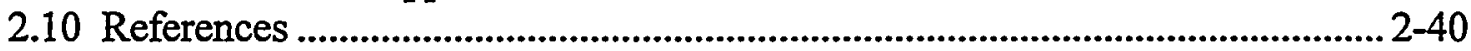

3 HAZARD AND ACCIDENT ANALYSIS.............................................................. 3-1

3.1 Introduction .................................................................................................. 3-1

3.2 Requirements ........................................................................................ 3-2

3.3 Hazard Analysis ..................................................................................... 3-2

3.3.1 Methods................................................................................................... 3-3

3.3.1.1 Hazard Identification ................................................................. 3-3

3.3.1.2 Hazard Evaluation ................................................................. 3-6

3.3.2 Hazard Analysis Results .................................................................... 3-10

3.3.2.1 Hazard Identification ........................................................ 3-10

3.3.2.2 Hazard Classification ................................................................. 3-12

3.3.2.3 Hazard Evaluation .............................................................. 3-13

3.3.2.3.1 Planned Design and Operational Safety

Improvements ............................................................ 3-14

3.3.2.3.2 Defense in Depth ..................................................... 3-21

3.3.2.3.3 Worker Safety .......................................................... 3-23

3.3.2.3.4 Environmental Protection .................................... 3-24

3.3.2.3.5 Accident Selection ................................................ 3-24 


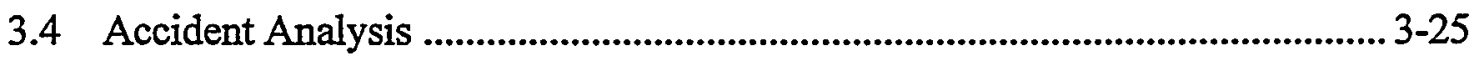

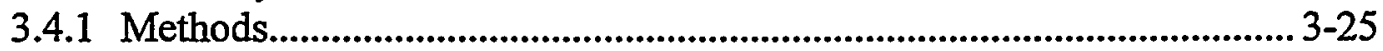

3.4.1.1 Source Term Estimation ......................................................3-25

3.4.1.1.1 Radioactive Source Term Estimation .................... 3-25

3.4.1.1.2 Chemical Source Term Estimation .........................3-27

3.4.1.2 Dose Consequence Evaluation.................................................. 3-27

3.4.1.2.1 Radioactive Dose Consequence Evaluation........... 3-28

3.4.1.2.2 Chemical Dose Consequence Evaluation ............. 3-29

3.4.1.3 Evaluation Guidelines............................................................ 3-30

3.4.1.3.1 Radioactive Source Evaluation Guidelines............ 3-30

3.4.1.3.2 Chemical Source Evaluation Guidelines ............... 3-30

3.4.2 Design Basis Accidents ...................................................................... 3-31

3.4.2.1 Fire Inside Hot Cell-Ignition of Flammable Materials......... 3-31

3.4.2.1.1 Scenario Development .......................................... 3-31

3.4.2.1.2 Source Term Analysis ............................................. 3-32

3.4.2.1.3 Consequence Analysis ........................................... 3-32

3.4.2.1.4 Comparison to Guidelines ..................................... 3-33

3.4.2.1.5 Summary of Safety-Class SSCs and TSR

Controls ...................................................................3-33

3.4.2.2 Fire Inside Hot Cell - Autoignition of Reactive Metals ......... 3-33

3.4.2.2.1 Scenario Development ..........................................3-33

3.4.2.2.2 Source Term Analysis ............................................. 3-34

3.4.2.2.3 Consequence Analysis ......................................... 3-34

3.4.2.2.4 Comparison to Guidelines ...................................... 3-34

3.4.2.2.5 Summary of Safety-Class SSCs and TSR

Controls ...............................................................3-34

3.4.2.3 Fire Outside Hot Cell-Vehicular Equipment Malfunction .. 3-34

3.4.2.3.1 Scenario Development .........................................3-35

3.4.2.3.2 Source Term Analysis .............................................. 3-35

3.4.2.3.3 Consequence Analysis .......................................... 3-35

3.4.2.3.4 Comparison to Guidelines ................................... 3-35

3.4.2.3.5 Summary of Safety-Class SSCs and TSR Controls .................................................................3-35

3.4.2.4 Earthquake Initiates Fire Outside Hot Cell .............................3-36

3.4.2.4.1 Scenario Development ............................................3-36

3.4.2.4.2 Source Term Analysis ..........................................3-36

3.4.2.4.3 Consequence Analysis ........................................3-36

3.4.2.4.4 Comparison to Guidelines ................................... 3-37

3.4.2.4.5 Summary of Safety-Class SSCs and TSR Controls ................................................................3-37

3.4.2.5 Deflagration Inside Hot Cell-Ignition of Flammable Gas.... 3-37

3.4.2.5.1 Scenario Development ........................................3-37

3.4.2.5.2 Source Term Analysis ............................................. 3-37

3.4.2.5.3 Consequence Analysis .......................................3-38

3.4.2.5.4 Comparison to Guidelines ........................................ 3-38 
3.4.2.5.5 Summary of Safety-Class SSCs and TSR

Controls .................................................................. 3-38

3.4.2.6 External Exposure to Worker-Failure of Passive Radiation Shielding.

3.4.2.6.1 Scenario Development 3-38

3.4.2.6.2 Source Term Analysis 3-38

3.4.2.6.3 Consequence Analysis 3-39

3.42 .6 .4

3.4.2.6.5 Summary of Safety-Class SSCs and TSR Controls

3.4.2.7 External Exposure to worker-Exposed Source Above Permanent Shield Wall 3-39

Scenario Development

Development ….......

3.4.2.7.2 Source Term Analysis ......................................... 3-40

3.4.2.7.3 Consequence Analysis ........................................... 3-40

3.4.2.7.4 Comparison to Guidelines ..................................... 3-40

3.4.2.7.5 Summary of Safety-Class SSCs and

TSR Controls ...........................................................3-40

3.4.2.8 Chemical Release from the AHCF ........................................ 3-40

3.4.3 Beyond Design Basis Accidents ............................................................ 3-40

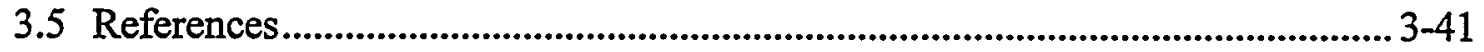

4 SAFETY STRUCTURES, SYSTEMS, AND COMPONENTS................................. 4-1

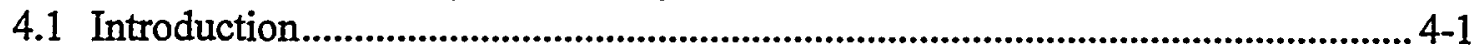

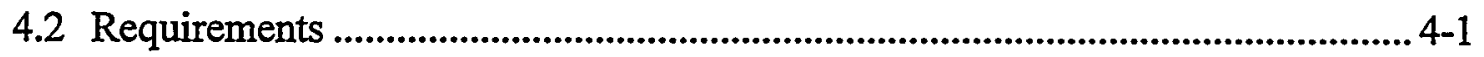

4.3 Safety Class Systems, Structures, and Components ........................................... 4-2

4.4 Safety-Significant Structures, Systems, and Components ..................................... 4-2

4.4.1 Hot Cell Structure ............................................................................. 4-3

4.4.1.1 Safety Function ..................................................................... 4-3

4.4.1.2 System Description .................................................................. 4-3

4.4.1.3 Functional Requirements ......................................................... 4-5

4.4.1.4 System Evaluation .............................................................. 4-5

4.4.1.5 Controls (TSRs) ................................................................... 4-5

4.4.2 Permanent Shield Wall ............................................................................ 4-6

4.4.2.1 Safety Function ....................................................................... 4-6

4.4.2.2 System Description ............................................................. 4-6

4.4.2.3 Functional Requirements ..................................................... 4-6

4.4.2.4 System Evaluation .............................................................. 4-6

4.4.2.5 Controls (TSRs) .................................................................. 4-7

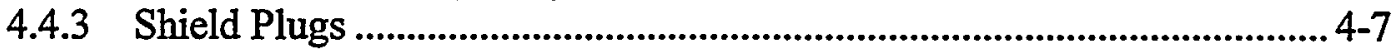

4.4.3.1 Safety Function ...................................................................... 4-7

4.4.3.2 System Description .................................................................. 4-7

4.4.3.3 Functional Requirements ......................................................... 4-7

4.4.3.4 System Evaluation ............................................................ 4-8

4.4.3.5 Controls (TSRs) ......................................................................... 4-8

4.4.4 Ventilation System............................................................................................. 4-8 
4.4.4.1 Safety Function ......................................................................... 4-8

4.4.4.2 System Description .................................................................... 4-8

4.4.4.3 Functional Requirements .......................................................... 4-9

4.4.4.4 System Evaluation ....................................................................... 4-9

4.4.4.5 Controls (TSRs) ......................................................................... 4-9

4.4.5 HEPA Filters....................................................................................... 4-10

4.4.5.1 Safety Function .................................................................... 4-10

4.4.5.2 System Description .................................................................. 4-10

4.4.5.3 Functional Requirements .......................................................... 4-10

4.4.5.4 System Evaluation ................................................................... 4-10

4.4.5.5 Controls (TSRs) ....................................................................... 4-10

4.5 References............................................................................................. 4-10

5 DERIVATION OF TECHNICAL SAFETY REQUIREMENTS............................... 5-1

5.1 Introduction........................................................................................................ 5-1

5.2 Requirements ....................................................................................................... 5-1

5.3 TSR Coverage ............................................................................................ 5-2

5.4 Derivation of Facility Modes .................................................................................. 5-4

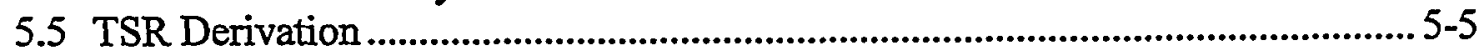

5.5.1 Ventilation System ................................................................................ 5-5

5.5.1.1 Safety Limits, Limiting Control Settings, and

Limiting Conditions for Operation .............................................. 5-7

5.5.1.2 Surveillance Requirements ......................................................5-7

5.5.1.3 Administrative Controls ........................................................... 5-7

5.5.2 HEPA Filtration System .......................................................................... 5-7

5.5.2.1 Safety Limits, Limiting Control Settings, and

Limiting Conditions for Operation ............................................. 5-8

5.5.2.2 Surveillance Requirements ...................................................... 5-8

5.5.2.3 Administrative Controls .........................................................5-8

5.5.3 Radioactive Material Limits ................................................................... 5-8

5.5.3.1 Safety Limits, Limiting Control Settings, and

Limiting Conditions for Operation ............................................ 5-8

5.5.3.2 Surveillance Requirements ...................................................... 5-8

5.5.3.3 Administrative Controls ........................................................... 5-8

5.5.4 Flammable Material Limits........................................................................ 5-9

5.5.4.1 Safety Limits, Limiting Control Settings, and

Limiting Conditions for Operation ............................................ 5-9

5.5.4.2 Surveillance Requirements ..................................................... 5-9

5.5.4.3 Administrative Controls ......................................................... 5-9

5.5.5 Worker Access Controls ............................................................................ 5-9

5.5.5.1 Safety Limits, Limiting Control Settings, and
Limiting Conditions for Operation ........................................... 5-9

5.5.5.2 Surveillance Requirements ..................................................... 5-9

5.5.5.3 Administrative Controls ......................................................... 5-10

5.5.6 Other Administrative Controls.................................................................. 5-10 


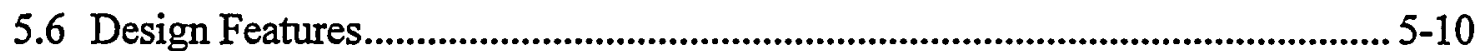

5.6.1 Fire Prevention and Mitigation Features............................................. 5-10

5.6.2 Radiation Shielding Features .......................................................... 5-10

5.7 Interface with TSRs from Other Facilities.................................................... 5-12

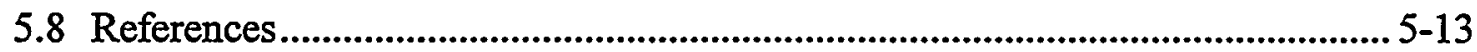

Appendix 3-A: Preliminary Hazard Assessment .......................................................3-A-1

Appendix 3-B: Probability Table for Hazard Evaluation .............................................. 3-B-1

Appendix 3-C: DBA Event Tree Analyses........................................................ 3-C-1

Appendix 3-D: External Events Screening Assessment ............................................... 3-D-1 


\section{TABLES}

11. Assigned Occupancy, Page

1-1. Assigned Occupancy, TA-V and Vicinity, January 1999................................... 1-11

1-2. Three-Year Climatological Data for the A36 Tower ............................................ 1-14

1-3. Average Wind Speeds (WS) for Each Stability Class and Frequencies of Stabilities for TA-V.....................................................................................1-15

1-4. Major Soil Classifications for TA-V and Arroyo del Coyote Drainage Area..................................................................................1-19

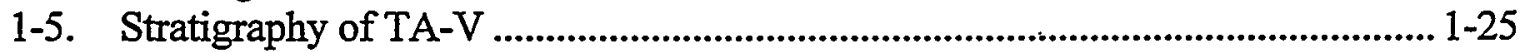

3-1. Hazard Identification ..................................................................................... 3-4

3-2. Consequence Severity Categories .................................................................. 3-8

3-3. Frequency Categories ........................................................................................... 3-9

3-4. Risk Ranking Matrix ................................................................................. 3-9

3-5a. Impact on Public and Environment - Fire in Hot Cell...................................... 3-14

3-5b. Impact on Public and Environment - Fire Outside Hot Cell ............................. 3-15

3-5c. Impact on Public and Environment - Deflagration Inside Hot Cell ................... 3-15

3-5d. Impact on Public and Environment - Deflagration Outside Hot Cell................. 3-16

3-5e. Impact on Public and Environment Radioactive Contamination Outside Hot Cell .....................................................3-16

3-6a. Impact on Colocated Worker or Facility - Fire in Hot Cell................................ 3-17

3-6b. Impact on Colocated Worker or Facility - Fire Outside Hot Cell ...................... 3-17

3-6c. Impact on Colocated Worker or Facility Deflagration Inside Hot Cell ................................................................................ 3-18

3-6d. Impact on Colocated Worker or Facility Deflagration Outside Hot Cell ............................................................................ 3-18

3-6e. Impact on Worker, Colocated Worker or Facility Radioactive Contamination Outside Hot Cell ..................................................... 3-19

3-6f. Impact on Worker, Colocated Worker or Facility Worker Exposure.

3-7. Dose Estimates for Release of Pu-239 from AHCF ........................................... 3-27

4-1. AHCF Safety-Significant SSCs ................................................................ 4-4

5-1. TSR Coverage Summary …........................................................................ 5-4

5-2. AHCF Mode Definitions ......................................................................... 5-6

5-3. AHCF Administrative Control Summary ........................................................ 5-11 


\section{FIGURES}

1-1. Albuquerque/KAFB

1-2. Sandia Technical Areas and Coyote Canyon Test Field ....................................... 1-4

1-3. Technical Area V and Vicinity, Showing the Location of the AHCF

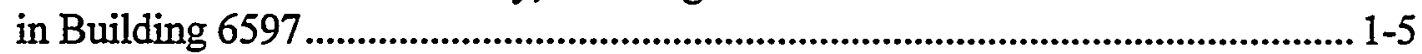

1-4. Point Where Evaluation Guidelines Are Applied .............................................. 1-8

1-5. Meteorological Monitoring Stations ............................................................1-13

1-6. Day and Nighttime Wind Roses for the A36 Tower (1997) .............................. 1-16

1-7. Potentiometric Surface and Groundwater Flow Directions for the Regional Groundwater System................................................................... 1-20

1-8. Monitor Well Locations in the Vicinity of TA-V .......................................... 1-22

1-9. Seismic Risk Map of the United States and Puerto Rico .................................... 1-26

1-10. Map of Central Rio Grande Region of New Mexico Showing Locations of Magnitude $\geq 3.0$ Earthquakes Detected by NM Institute of Mining and Technology Seismographs for the Period 1986 - 1994 .................... 1-28

1-11. Fault Zones Near TA-V.......................................................................... 1-29

2-1. Basic Configuration of Building 6597 ................................................................. 2-5

2-2. Auxiliary Hot Cell Facility................................................................................ 2-8

2-3. Hot Cell Structural and Mechanical Components............................................. 2-12

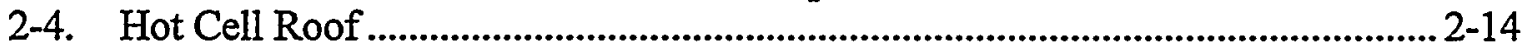

2-5. Hot Cell Process Equipment....................................................................... 2-20

2-6. Flow Chart Showing Typical AHCF Process....................................................2-23

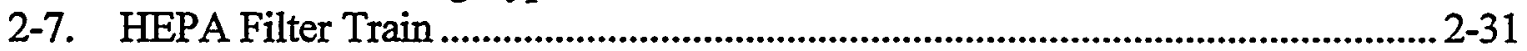

2-8. Building Trenches .................................................................................... 2-34

3-1. Hazard Evaluation Process: Identification of Safety Functions and Safety-Related SSCs....................................................................................... 3-22 


\section{ACRONYMS AND ABBREVIATIONS}

ACGIH

ACRR

AHCF

ALARA

ALOHA

ANS

ANSI

ARAC

CAM

CAMEO

CAN

CEDE

CFR

CMU

CRL

CSA

DBA

DOC

DOD

DOE

DOE STD

DOT

EDE

$\mathrm{EF}$

EPA

ERPG-2

ES\&H

ET

FMEF

FR

GIF

$\mathrm{HCF}$

HEPA

HP

HVAC

HWMF

ICBO

ID

ISMS

ISS

KAFB

KUMSC

LANMAS
American Conference of Governmental Industrial Hygienists

Annular Core Research Reactor

Auxiliary Hot Cell Facility

As low as reasonably achievable

Areal Locations of Hazardous Atmospheres

American Nuclear Society

American National Standards Institute

Atmospheric Release Advisory Code

Continuous air monitor

Computer Aided Management of Emergency Operations

Clean Air Network

Committed effective dose equivalent

Code of Federal Regulations

Concrete masonry unit

Central Research Laboratory

Criticality safety assessment

Design basis accident

U.S. Department of Commerce

U.S. Department of Defense

U.S. Department of Energy

U.S. Department of Energy Standard

U.S. Department of Transportation

Effective dose equivalent

Exhaust fan

U.S. Environmental Protection Agency

Emergency Response Planning Guidelines Level 2

Environmental safety and health

Event tree

Fuel and Materials Examination Facility

Federal Register

Gamma Irradiation Facility

Hot Cell Facility

High efficiency particulate air

Health physics

Heating, ventilation, and air conditioning

Hazardous Waste Management Facility

International Conference of Building Officials

Inside diameter

Integrated Safety Management System

Interim Storage Site

Kirtland Air Force Base

KAFB Underground Munitions Storage Center

Local Area Network Materials Accountability System 


$\begin{array}{ll}\text { LCO } & \text { Limiting condition for operation } \\ \text { LCS } & \text { Limiting control setting } \\ \text { LEL } & \text { Lower explosion limit } \\ \text { MACCS2 } & \text { MELCOR Accident Consequence Code System Version 2 } \\ \text { MSL } & \text { Melting and Solidification Laboratory } \\ \text { MUA } & \text { Makeup air } \\ \text { NESHAP } & \text { National Emission Standards for Hazardous Air Pollutants } \\ \text { NFPA } & \text { National Fire Protection Agency } \\ \text { NNSI } & \text { Nonproliferation and National Security Institute } \\ \text { NPR } & \text { New Production Reactor } \\ \text { NRC } & \text { Nuclear Regulatory Commission } \\ \text { NWS } & \text { National Weather Service } \\ \text { OP } & \text { Operating procedure } \\ \text { OSHA } & \text { Occupational Safety and Health Administration } \\ \text { PA } & \text { Public address } \\ \text { PAB } & \text { Perimeter Access Building } \\ \text { PEL } & \text { Permissible exposure limit } \\ \text { PHA } & \text { Preliminary hazard assessment } \\ \text { PNL } & \text { Pacific Northwest Laboratory } \\ \text { PPE } & \text { Personnel protective equipment } \\ \text { PSAR } & \text { Preliminary Safety Analysis Report } \\ \text { PSM } & \text { Process safety management } \\ \text { RAM } & \text { Remote area monitor } \\ \text { RCSC } & \text { Radiological and Criticality Safety Committee } \\ \text { RCRA } & \text { Resource Conservation and Recovery Act } \\ \text { RML } & \text { Radiation Metrology Laboratory } \\ \text { RMWMF } & \text { Radioactive and Mixed Waste Management Facility } \\ \text { RPPM } & \text { Radiological Protection Procedures Manual } \\ \text { SAR } & \text { Safety Analysis Report } \\ \text { SCSSC } & \text { Safety class SSC } \\ \text { SIH } & \text { Standard industrial hazard } \\ \text { SL } & \text { Safety limit } \\ \text { SNL/NM } & \text { Sandia National Laboratories/New Mexico } \\ \text { SNM } & \text { Special nuclear material } \\ \text { SPO } & \text { Security police officer } \\ \text { SPR } & \text { Sandia Pulse Reactor } \\ \text { SR } & \text { Surveillance requirement } \\ \text { SRS } & \text { Savannah River Site } \\ \text { SSCs } & \text { Structures, systems, or components } \\ \text { SSSSC } & \text { Safety significant SSC } \\ \text { STD } & \text { Standard } \\ \text { TA } & \text { Technical Area } \\ \text { TA-V } & \text { Technical Area V } \\ \text { TEDE } & \text { Total effective dose equivalent } \\ \text { TEDS } & \text { Training \& Employee Development System } \\ \text { TRU } & \text { Transuranic } \\ & \\ \text { SRU } & \end{array}$


TSD

TSR

UBC

UL

UPS

USAF

USDA

USQ

VFD

VIV

VOC

WAC

WS
Treatment, storage, or disposal

Technical safety requirements

Uniform Building Code

Underwriters Laboratory

Uninterrupted power source

U.S. Air Force

U.S. Department of Agriculture

Unreviewed safety question

Variable frequency drive

Variable inlet vane

Volatile organic compound

Waste acceptance criteria

Wind speed 


\section{UNIT LIST}

$\begin{array}{ll}\mathrm{acfm} & \text { actual cubic feet per minute } \\ \mathrm{cm} & \text { centimeter } \\ \mathrm{cfm} & \text { cubic feet per minute } \\ \mathrm{cm}^{2} & \text { square centimeter } \\ \mathrm{d} & \text { day } \\ \mathrm{dpm} & \text { disintegrations per minute } \\ \mathrm{fc} & \text { foot candle } \\ \mathrm{ft} & \text { foot } \\ \mathrm{ft}^{2} & \text { square feet } \\ \mathrm{ft}^{3} & \text { cubic feet } \\ \mathrm{g} & \text { gram } \\ \mathrm{gal} & \text { gallon } \\ \mathrm{hp} & \text { horsepower } \\ \mathrm{hr} & \text { hour } \\ \mathrm{in} . & \text { inch } \\ \mathrm{kCi} & \text { kilocurie } \\ \mathrm{kg} & \text { kilogram } \\ \mathrm{kV} & \text { kilovolt } \\ \mathrm{lb} & \text { pound } \\ \mathrm{m} & \text { meter } \\ \mathrm{m}^{2} & \text { square meter } \\ \mathrm{m} & \text { cubic meter } \\ \mathrm{MeV} & \text { million electron volts } \\ \mathrm{mrem} & \text { millirem } \\ \mathrm{psi} & \text { pounds per square inch } \\ \mathrm{V} & \text { volt } \\ \mathrm{w.c.} & \text { water column } \\ \Delta \mathrm{P} & \text { pressure difference } \\ & \\ \end{array}$




\section{EXECUTIVE SUMMARY}

\section{E.1 BACKGROUND AND MISSION}

The mission of the Auxiliary Hot Cell Facility (AHCF) at Sandia National Laboratories, New Mexico (SNL/NM) will be to safely characterize, treat (if required), and repackage radioactive and mixed material and waste for reuse, recycling, or ultimate disposal. A significant upgrade to the previous facility, the Temporary Hot Cell, will be implemented to support this mission. The following major features will be added:

- A permanent shield wall will extend northward from the west wall of the hot cell.

- Eight floor silos will be constructed-two inside the hot cell, and six behind the permanent shield wall. These silos will facilitate package handling and will be used for shielding during operations and for storage. Each one of the six silos behind the permanent shield wall will be an independent Category 3 nuclear facility.

- The hot cell roof will be replaced to allow the placement of two roof portals over the two silos in the hot cell.

- A ventilation system will be upgraded to a two-stage high efficiency particulate air (HEPA) filter serving a fume hood and temporary room as well as the hot cell.

- The existing hot-cell jib crane will be upgraded.

- Video cameras will record operations and facilitate remote-handled operations.

These features will enhance SNL/NM's ability to safely characterize, handle, treat, and package its radioactive legacy inventory.

The type and quantity of radionuclides that could be located in the AHCF are defined primarily by SNL/NM's legacy materials, which include radioactive, transuranic (TRU), and mixed waste that are inappropriate for processing at SNL's Radioactive and Mixed Waste Management Facility (RMWMF), due either to their form or quantity. Most of this waste and other legacy materials exceed Category 3 thresholds for radioactive material or present a handling hazard from ionizing radiation.

\section{E.2 FACILITY OVERVIEW}

The AHCF will be operated by SNL/NM on Kirtland Air Force Base (KAFB) in Albuquerque. It is located in the High Bay of Building 6597 of Technical Area V (TA-V). The AHCF will include (1) a hot cell; (2) a permanent shield wall extending from the hot cell; (3) a field-fabricated temporary room, to be assembled behind the permanent shield wall for contamination control as necessary; (4) a walk-in fume hood; and (5) associated work areas within the High Bay of Building 6597. Eight storage silos 
will be constructed. Six storage silos (four 25.4- $\mathrm{cm}$ [10-in.] inside diameter [ID], 4.6-m [15-ft]-deep silos and two 76.2-cm [30-in.] ID, 4.6-m [15-ft]-deep silos) will be located in the floor east of the permanent shield wall and north of the hot cell. Two storage silos, each $25.4 \mathrm{~cm}(10 \mathrm{in}$.) ID and $4.6 \mathrm{~m}(15 \mathrm{ft})$ deep, will be located in the floor of the hot cell.

Other nuclear facilities within TA-V include the Sandia Pulse Reactor (SPR), the Annular Core Research Reactor (ACRR), the Gamma Irradiation Facility (GIF), and the Hot Cell Facility (HCF). TA-V is located at the northeast corner of a larger SNL/NM testing site, TA-3, which contains numerous non-nuclear test facilities and is five miles south of the main SNL/NM site. The maximally exposed off-site individual is located approximately 3000 meters from the facility, which corresponds to the nearest boundary of KAFB.

\section{E.3 FACILITY HAZARD CLASSIFICATION}

The AHCF has been classified as a Hazard Category 3 nuclear facility based on the planned radioactive material inventory compared to Hazard Category 2 threshold levels. The AHCF has been divided into seven segments for final hazard categorization. The Building 6597 High Bay and hot cell form one segment, and each of the six individual storage silos behind the permanent shield wall forms a separate segment. The storage silos may be segmented from the main facility and from each other because the physical construction of the silos isolates them from involvement in accidents in the main facility. Each of the seven segments will comprise a separate Hazard Category 3 nuclear facility, and the radioactive inventory of each segment will be maintained below Category 2 thresholds. Administrative controls that regulate inventory will be used to ensure that the inventory in the High Bay and hot cell never exceeds the Category 2 threshold, even during the movement of packages in and out of the silos behind the permanent shield wall.

\section{E.4 SAFETY ANALYSIS OVERVIEW}

The most severe hazard to AHCF personnel is the potential for direct radiation exposure during processing of highly radioactive materials and waste. The design of hot cell, permanent shield wall, and shield plugs meets all worker safety requirements, assuming the bounding limit of a $6.0 \mathrm{kCi}$ source of mixed fission products, 120 days postirradiation, placed in the most optimal position for worker exposure. This source represents the highest dose to personnel from gamma radiation. Extensive radiation shielding has been incorporated into the design of these elements of the AHCF to control the direct radiation dose for operations within the hot cell and behind the permanent shield wall. Colocated workers are subject to the greatest potential hazard when exposed sources are lifted above the permanent shield wall for insertion into the hot cell.

The most severe hazard for members of the public is the potential inhalation of radioactive material released as a result of an accident in the AHCF. Pu-239 at the Category 2 threshold level was used to estimate the consequence of accidental release of radioactive material. (The "Category 2 threshold level" is the minimum inventory that would cause a facility to be a Category 2 nuclear facility. The inventory of a Category 3 nuclear facility 
is always less than this Category 2 threshold level.) $\mathrm{Pu}-239$ represents a bounding case for release of nonvolatile materials present at the facility at the Category 2 threshold quantity. Minimal quantities of volatiles are expected at the AHCF. The release of a given amount of respirable $\mathrm{Pu}-239$ (an alpha emitter) results in a greater effective dose equivalent (EDE) at the exclusion-area boundary than release of the same amount of any of the nonvolatile isotopes of interest, except americium-241. However, unlike Am-241, $\mathrm{Pu}-239$ is pyrophoric. Therefore, a fire that reaches the ignition temperature of plutonium will release a greater fraction of the metal than would be released in a fire involving a nonpyrophoric material. Furthermore, Pu-239 exhibits a very steep doseresponse curve. Because of its high EDE, pyrophoric nature, and steep dose response, the use of $\mathrm{Pu}-239$ results in a conservative, but not unrealistic, estimate. Although less than $1 \%$ of the existing waste packages approach Category 2 threshold quantities, packages containing Pu-239 at near-Category-2-threshold levels do exist in the current inventory.

Several representative accidents are identified as design basis accidents (DBAs) for more detailed qualitative evaluation. These include three release scenarios within the hot cell, two release scenarios within the High Bay, a release due to an earthquake, and several scenarios with the potential consequence of worker exposure to ionizing radiation. These accidents are as follows:

- Fire inside hot cell-ignition of flammable materials (representative),

- Fire inside hot cell-autoignition of reactive metals (representative),

- Fire outside hot cell-vehicular equipment malfunction (representative),

- Fire outside hot cell; external event-earthquake (bounding),

- Deflagration inside hot cell-ignition of flammable gas (bounding),

- External exposure to worker-failure of passive radiation shielding (bounding),

- External exposure to worker-exposed source above the permanent shield wall (representative), and

- Chemical release from the AHCF (bounding).

Potential impacts to the public from these accidents are bounded by assuming the total inventory consists of Category 2 threshold quantities of $\mathrm{Pu}-239$. Impacts to workers and colocated workers are bounded by assuming a radiation source of $6 \mathrm{kCi}$ mixed fission products, 120 days post-irradiation. Evaluation of potential chemical exposure is bounded by hydrogen fluoride gas at appropriate Process Safety Management (PSM) threshold quantities.

\section{E.5 SAFETY ANALYSIS CONCLUSIONS}

The accident analysis has been conducted in such a way that the results are extremely conservative. Bounding quantities of radionuclides have been used to calculate doses to the public and doses to workers. Event probabilities have been determined from the literature, set conservatively high, or both. No credit has been taken for such mitigating 
factors as the presence of HEPA filters or package inventories that are in general much smaller than the Category 2 threshold quantities used in the analysis.

In spite of the conservatism of the accident analysis, the results confirm that risk to the public or the environment is minor due to the inventory limitations of the Hazard Category 3 classification. Potential doses at the exclusion boundary are well below the evaluation guidelines of $25 \mathrm{rem}$. Potential for worker exposure is limited by the passive design features incorporated in the AHCF and by SNL's radiation protection program, as documented in the Radiation Protection Procedures Manual (RPPM). There is no potential for exposure of the public to chemical hazards above the Emergency Response Protection Guidelines Level 2 (ERPG-2).

Because there is no potential to exceed the evaluation guidelines at the exclusion boundary, no safety-class systems, structures, and components (SSCs) are found in the AHCF. There are five safety-significant SSCs:

- Hot cell structure,

- Permanent shield wall,

- Shield plugs,

- Ventilation system, and

- HEPA filters.

The hot cell structure, permanent shield wall, and shield plugs are design features providing worker safety. They will not require Technical Safety Requirements (TSRs). The ventilation system serves the hot cell, temporary room, and fume hood and provides confinement preventing the uncontrolled release of radioactive material. TSRs, including Limiting Conditions for Operations (LCOs) and Surveillance Requirements (SRs), will govern the ventilation system. The HEPA filters are part of the ventilation system and will require individual TSRs including LCOs and SRs.

The safe operation of the AHCF will also be ensured by administrative controls, including inventory restrictions on radioactive and hazardous materials, radiation monitoring, radiation area access controls, criticality controls, and other elements of existing SNL safety programs.

\section{E.6 PSAR ORGANIZATION}

This safety analysis has been prepared in accordance with the guidelines of DOE-STD3009-94 and is presented in the format described in that standard. 


\section{CHAPTER 1}

\section{SITE CHARACTERISTICS}

\section{$1.1 \quad$ INTRODUCTION}

Chapter 1 provides information that will satisfy the requirements of U.S. Department of Energy (DOE) Order 5480.23, paragraph 8.b.(3)(c). ${ }^{1}$ It also includes applicable information that will partialiy satisfy the requirements of DOE Order 5480.23, paragraphs 8.b.(3)(b), (f), and (u). ${ }^{2}$ This chapter describes site characteristics that affect the safety basis of the facility. More specifically, information provided in Chapter 1 supports assumptions used in the hazard and accident analyses that consider potential accident initiators and accident consequences external to the facility under study, the Auxiliary Hot Cell Facility (AHCF).

\subsection{REQUIREMENTS}

Several DOE orders establish the safety basis for the AHCF. The following list describes and summarizes the major orders and standards pertinent to Chapter 1:

- DOE Standard 3009-94, "Preparation Guide for U.S. Department of Energy Nonreactor Nuclear Facility Safety Analysis Reports" - This standard describes a preparation method for Safety Analysis Reports (SARs) that satisfies the requirements of DOE Order 5480.23 and is acceptable to the DOE (DOE 1994b).

- DOE Order 5480.23, Chg. 1, "Nuclear Safety Analysis Reports" - This order requires the documentation of site characteristics that may affect the safety basis for the facility (DOE 1994a).

- DOE Order 420.1, Chg. 2, "Facility Safety"-This order requires the assessment of natural hazards for the facility (DOE 1996).

\subsection{SITE DESCRIPTION}

Sandia National Laboratories is a multiprogram laboratory operated by Sandia Corporation, a Lockheed Martin Company, for the DOE under contract DE-AC04-94AL85000. Sandia National Laboratories/New Mexico (SNL/NM) is located on Kirtland Air Force Base (KAFB). Other installations located on KAFB include the DOE Albuquerque Operations Office, the Defense Threat Reduction Agency, the U.S. Air Force Operational Test and Evaluation Center, the KAFB Underground Munitions Storage Center (KUMSC), the KAFB administrative offices, and several smaller agencies.

\footnotetext{
${ }^{1}$ As amplified in Attachment 1, paragraph 4.f.(3)(d)3, of the Order (Topic 3).

2 As discussed in the Introduction to DOE-STD-3009-94 (DOE 1994b).
} 


\subsubsection{Geography}

Section 1.3.1 presents basic geographic information about SNL/NM and Technical Area V (TA-V), the area where the AHCF will be located.

\subsubsection{SNL/NM Site Description}

SNL NM is situated south of Albuquerque, New Mexico, within the boundaries of KAFB, a U.S. Air Force (USAF) military reservation (Figure 1-1). SNL/NM facilities are located on DOE-leased land allocated within KAFB. KAFB covers approximately 52,000 acres.

Land use in the vicinity of SNL/NM and KAFB is urban to the northwest, north, and northeast. Isleta Pueblo lands, which are typically used for grazing, border the southern portion of KAFB. State-owned grazing land lies west and southwest of KAFB. The urbanized areas immediately northeast, north, and northwest of SNL/NM are predominantly residential, with commercial development along more heavily traveled streets. National Forest and rural residential areas are to the east. Military housing is located adjacent to the northern edge of SNL/NM TA-I. Albuquerque International Airport abuts $\mathrm{KAFB}$ on the west and shares runways and other flight facilities with it.

The general SNL/NM site consists of Coyote Canyon Test Field and five technical areas (TAs) (Figure 1-2). TA-I operations are dedicated primarily to research, development, and design of weapons systems; limited production of weapon system components; and energy programs. TA-II is a small area previously used for testing explosives. TA-IV contains several inertial-confinement-fusion and pulsed-power research facilities that house large accelerators. Various test activities take place on parcels of land scattered throughout Coyote Test Field.

The closest technical area to TA-V and the AHCF is TA-III. TA-III facilities embrace extensive test facilities (sled tracks, centrifuges, and a radiant heat facility). TA-III also encompasses the inactive chemical, mixed, and low-level waste landfills, ${ }^{3}$ the Melting and Solidification Laboratory (MSL), and the Radioactive and Mixed Waste Management Facility (RMWMF).

\subsubsection{2 - TA-V Site Description}

TA-V is located $5.4 \mathrm{~km}$ (3.4 mi) south of TA-I, which is the major SNL/NM installation. SNL/NM TA-III borders TA-V on the west and south (Figure 1-2).

The Hot Cell Facility (HCF, Building 6580), Gamma Irradiation Facility (GIF, Building 6588), Annular Core Research Reactor (ACRR, Building 6588), and the Sandia Pulse Reactor (SPR, Buildings 6591, 6592, and 6593) are other major facilities in TA-V. Building 6597, the location of the AHCF, sits in the southeastern quadrant of TA-V (Figure 1-3).

\footnotetext{
${ }^{3}$ The chemical landfall is currently being remediated.
} 


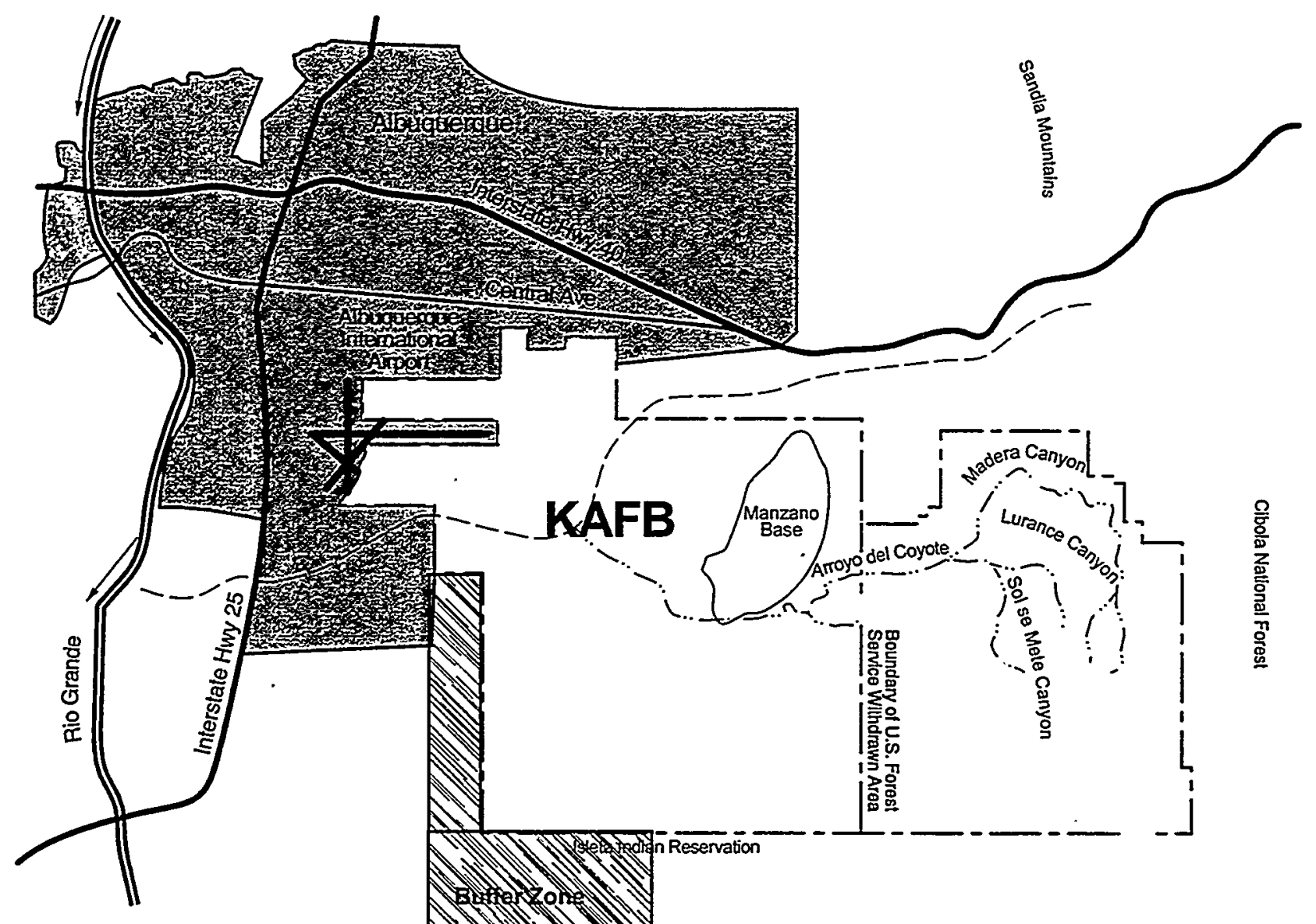

I.1.
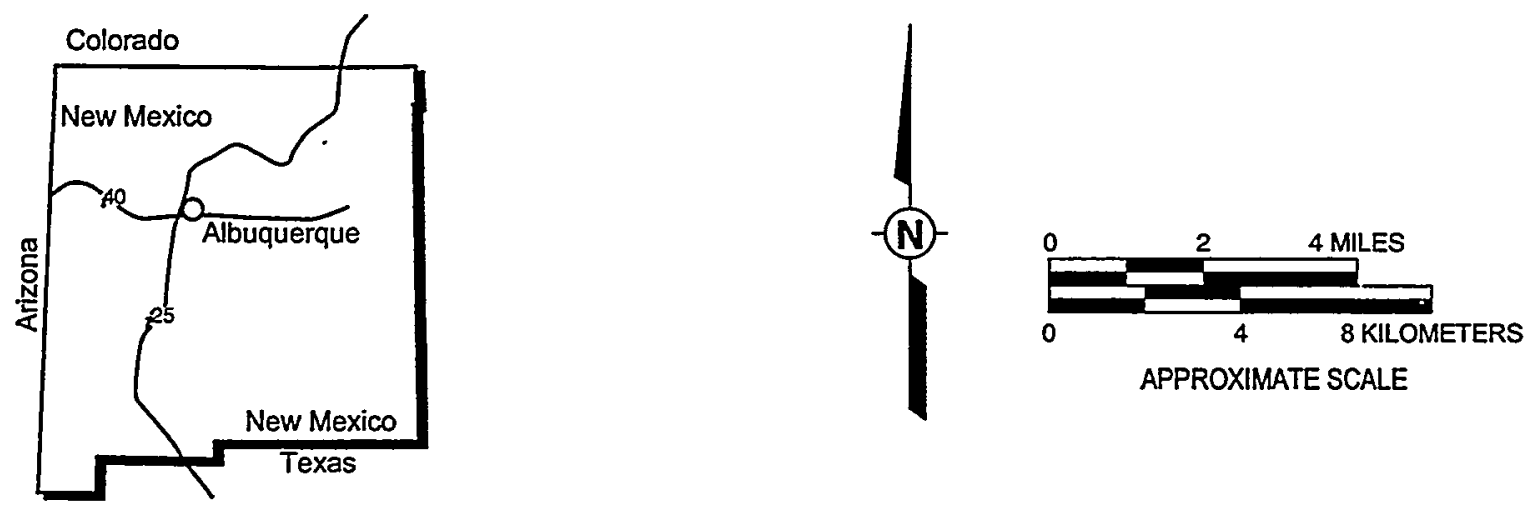

Figure 1-1. Albuquerque/KAFB. 


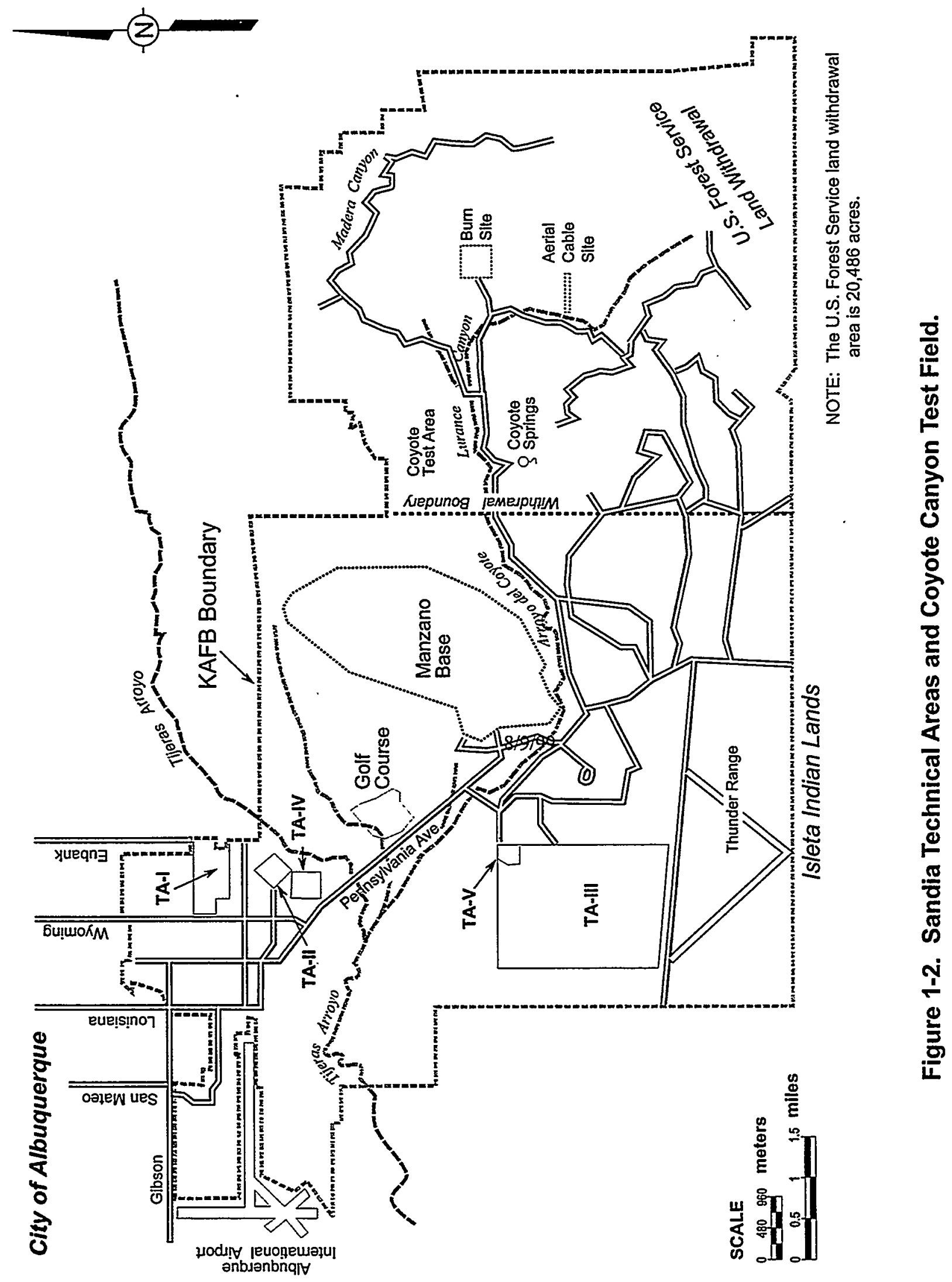




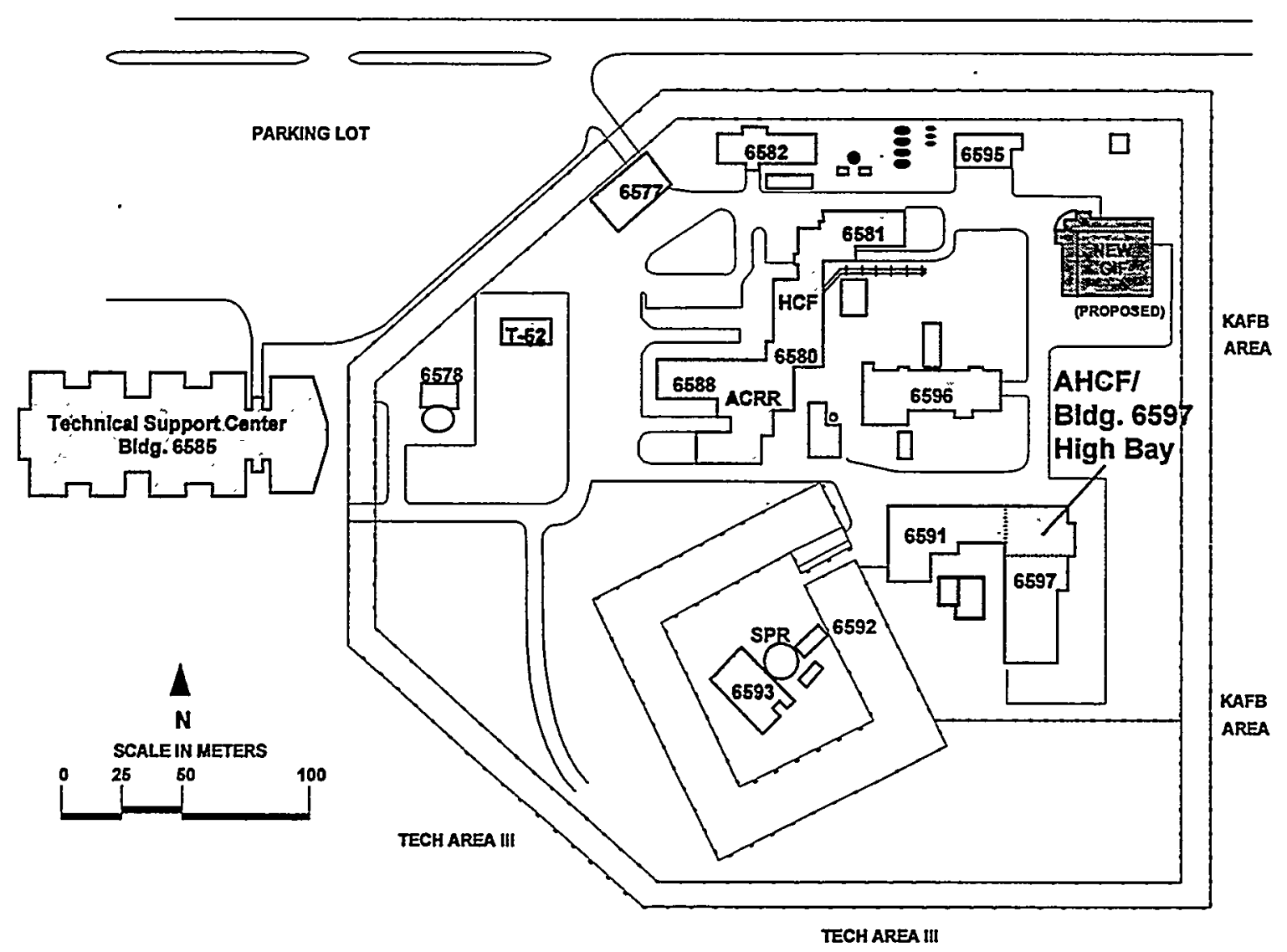

Figure 1-3. Technical Area V and Vicinity, Showing the Location of the AHCF in Building 6597 


\subsubsection{AHCF Site Description}

The AHCF and supporting equipment and structures such as the hot cell, fume hood, air filters, and cranes reside at the northern end of Building 6597 in a portion of the building called the High Bay. The AHCF and its systems are described in detail in Chapter 2.

The Nuclear Facility Support Department has direct operational and safety responsibility for the AHCF.

\subsubsection{Public Exclusion Areas}

The boundary of KAFB defines the extent of the area under KAFB/SNL jurisdiction. In addition, the DOE leases two parcels of land abutting the southwest corner of KAFB as a buffer zone for the SNL/NM sled track operations (SNL 1999b). Outside the KAFB and buffer zone boundaries, control is exercised by the City of Albuquerque, Bernalillo County, Isleta Pueblo, the State of New Mexico, or the U.S. Forest Service, depending on the jurisdiction.

Routine access to TA-V is over a paved access road connecting TA-V to the main paved road, Pennsylvania Avenue (Figure 1-2). This access road crosses one small arroyo, Arroyo del Coyote. The arroyo is normally dry, although during the rainy season the water may run deep enough to affect traffic briefly.

\subsubsection{Access Control}

Access to TA-V is controlled first at the main street entrances to KAFB (the Eubank, Wyoming, Gibson, Carlisle, Truman, and South Valley "gates"). No other vehicle or pedestrian entrances are authorized for public entry onto the Base. USAF personnel control access to KAFB at the main entrances and randomly patrol the perimeter elsewhere.

In addition to the main gate access controls, TA-V has an additional set of access controls. TA-V is completely enclosed by two standard security chain-link fences. All regular entries into and exits from TA-V are through Building 6577, the Perimeter Access Building (PAB), or through the adjoining vehicle gate (Figure 1-3).

Sandia's security police officers (SPOs) operate the PAB during business hours. The number of personnel on site is monitored by a computer-based personnel accounting system. This system provides the SPOs with an accurate count of the total number of persons within $T A-V$ at any given time. Ingress into and egress from $T A-V$ are normally through the PAB. There is, however, a second vehicle gate in the west fence and a personnel gate in the north fence; both are normally locked but may be opened if the PAB is unusable or inaccessible. Use of these alternative gates must be coordinated with the on-site SPOs and health physics personnel.

During an emergency, physical access to the site by emergency vehicles, such as fire trucks and ambulances, is coordinated through the Incident Commander or Emergency 
Supervisor. Organizations that are authorized to enter TA-V in case of emergencies are the SNL/NM Environmental and Emergency Management Department Incident Commanders, SNL/NM Medical Department and its contractor Albuquerque Ambulance, KAFB Fire Department, and USAF Security Police.

The SPOs provide emergency-response vehicles unimpeded access to the facility through the TA-V gate. In addition, the protective force provides emergency assistance as required by the SNL/NM Incident Commanders.

\subsubsection{Point Where Evaluation Guidelines Are Applied}

The AHCF is located approximately $3150 \mathrm{~m}$, conservatively rounded to $3000 \mathrm{~m}$ (1.9 mi) for this study, from the western boundary of KAFB. The evaluation guidelines are applied at the closest point along the western boundary of KAFB to the AHCF. All personnel and vehicular access into the area delineated by a $3000 \mathrm{~m}$ radius centered on $\mathrm{TA}-\mathrm{V}$ is controlled by the normal KAFB control points (i.e., KAFB vehicle/pedestrian entrance gates). In the event of an emergency, SNL/NM security forces, in conjunction with the KAFB security forces, have the authority to control access on all other roads within KAFB. There are no permanent residences inside this area; however, other SNL/NM and KAFB organizations conduct business within this area. Procedures for evacuating or sheltering personnel from these organizations are discussed in the TA-V Emergency Plan.

The location of the maximally exposed off-site individual, which is the point along the boundary where evaluation guidelines are applied, is taken to be at a distance of not less than $3000 \mathrm{~m}$ (1.9 mi) (Figure 1-4). This point lies on the boundary between KAFB and the DOE buffer zone. The buffer zone is not routinely inhabited; however, casual access to the buffer zone is controlled only during tests at the SNL/NM sled track (SNL 1999b).

\subsubsection{Demography}

Population and demographic information based on 1990 census data are included in this section to show the population distribution as a function of distance and direction from the AHCF.

\subsubsection{Albuquerque and Surrounding Area Demography}

Albuquerque is the largest population center in Bernalillo County and the state and the closest population center to KAFB. Within the general area, the population centers of major concern are metropolitan Albuquerque and Santa Fe. Albuquerque is adjacent to $\mathrm{KAFB}$, occupying all land from the southwest quadrant clockwise through the northeast quadrant (Figure 1-1). The metropolitan area (excluding the suburban communities) extends out to a maximum radius of about $21 \mathrm{~km}(13 \mathrm{mi})$ from TA-V. The 1990 census showed 384,736 people living within the city limits and more than 480,577 in Bernalillo County. An estimated total population of 572,000 people lives within an $80-\mathrm{km}(50-\mathrm{mi})$ radius of TA-V (DOC 1990). This population includes permanent residents of KAFB living in the KAFB housing areas. 


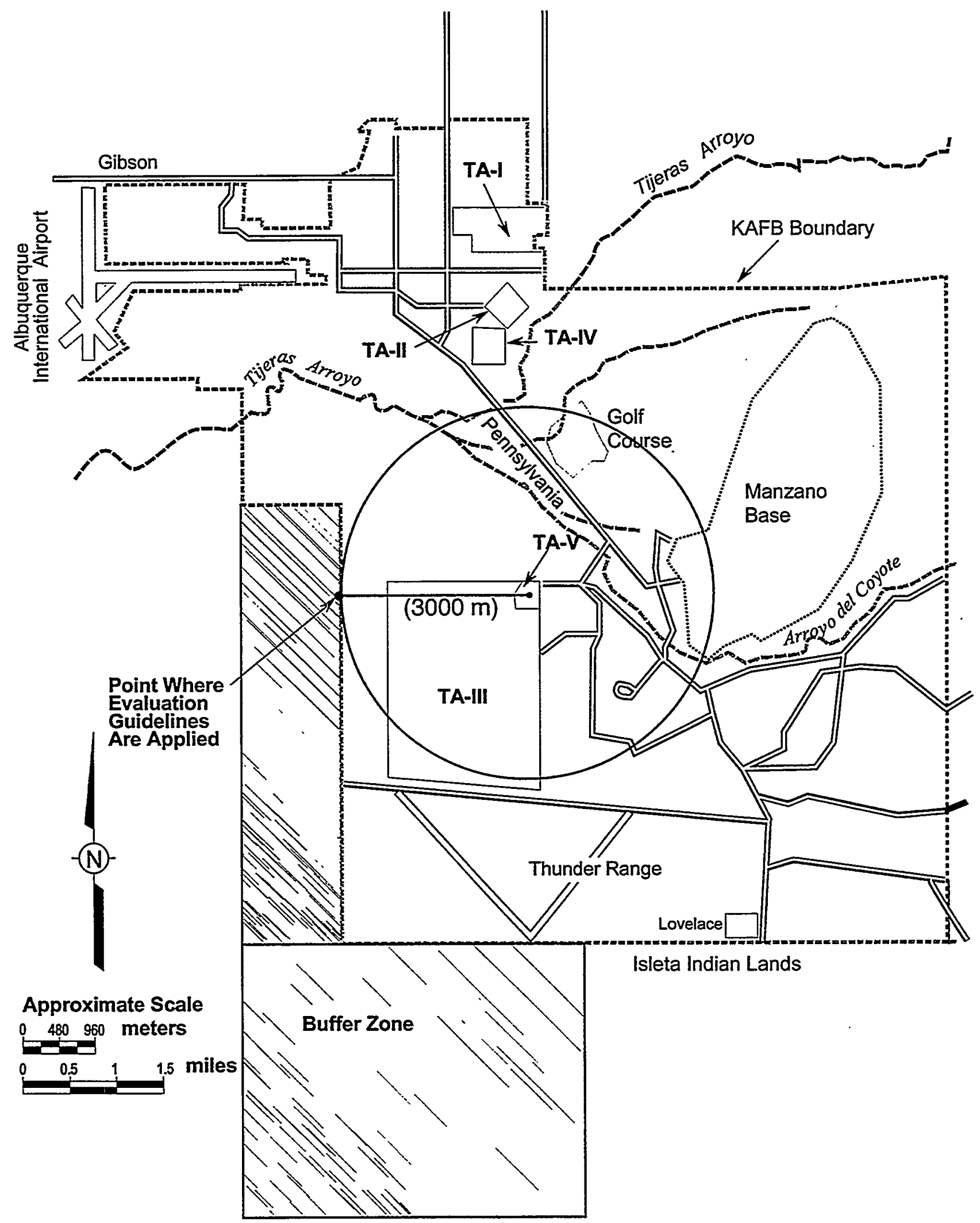

Figure 1-4. Point Where Evaluation Guidelines Are Applied. 
Rio Rancho, located $19 \mathrm{~km}$ (12 mi) northwest of KAFB, had a population of 32,505 in 1990. Santa Fe, located $90 \mathrm{~km}(56 \mathrm{mi})$ northeast, had a population of 56,557 at that time. Other population concentrations of concern are the Los Alamos area, $100 \mathrm{~km}(62 \mathrm{mi})$ north with a 1990 population of 18,115; and the Los Lunas-Belen-Socorro areas, 30 to $110 \mathrm{~km}$ (19 to $68 \mathrm{mi}$ ) south of Albuquerque on Interstate 25. In 1990, Los Lunas had a population of 6,013; Belen, 6,547; and Socorro, 8,159 (DOC 1990).

The KAFB/Isleta Indian land-grant boundary is $6.1 \mathrm{~km}(3.8 \mathrm{mi})$ south of TA-V; there are no permanent residences along the boundary. A private cattle company occupies two tracts of approximately 20 acres each within the buffer zone bordering the western boundary of KAFB, $3000 \mathrm{~m}$ (1.9 mi) from TA-V. In addition, Isleta Pueblo grazes cattle on the buffer zone that the pueblo has leased to the DOE. All areas within a radius of $3000 \mathrm{~m}(1.9 \mathrm{mi})$ of a point centered on TA-V, however, are under the control of SNL/NM or KAFB.

The Albuquerque International Airport terminal and maintenance facilities are located $9.3 \mathrm{~km}(5.8 \mathrm{mi})$ northwest of TA-V. The airport shares runways and other flight facilities with $\mathrm{KAFB}$, forming an integral unit. All the private and commercial facilities are located at the westernmost part of the airfield. The number of persons in the terminal and surrounding facilities varies, but peak occupancy may be several thousand people.

\subsubsection{Demography for KAFB and TAs Surrounding TA-V}

The four major locations whose populations would be of immediate interest are the SNL/NM TAs I, III, and IV and the KAFB Headquarters. The TA-I/KAFB Headquarters complex is located about $5.4 \mathrm{~km}(3.4 \mathrm{mi})$ north of the AHCF in TA-V. This complex has a total population of about 12,000 persons during normal business hours, which is the largest population group in the SNL/NM/USAF complex on KAFB. Of this number, about 8000 are SNL/NM employees and contractors. The remainder are associated with or attached to various military and civilian government organizations.

TA-IV is located $4.0 \mathrm{~km}(2.5 \mathrm{mi})$ north of TA-V and had an assigned occupancy in January 1999 of 722 persons, most of whom are SNL/NM employees. TA-III, adjacent to TA-V on the west and south sides, had an assigned occupancy of 278 persons. The number of persons on site may vary because of the transient nature of the diverse testing operations that occur in this area (SNL 1995c).

Several organizations have installations in and near the Manzano Administrative Area, located about $2.7 \mathrm{~km}(1.7 \mathrm{mi})$ northeast of TA-V. Few or no Sandians are normally present at the Manzano Waste Storage Facilities. The Nonproliferation and National Security Institute (NNSI; formerly the DOE Central Training Academy) has a population of about 150 staff, with an additional 150 students during spring, summer, and fall. ${ }^{4} \mathrm{~A}$ few times a year, the population rises above 300 for a few days at a time. There is no regular after-hours staff. A fire station, USAF dog kennels, and a branch office of the Air Force Research Laboratory (formerly Phillips Laboratory) have a combined population of

${ }^{4}$ Information provided by John Starr, Facility Manager, NNSI, 845-5170, ext. 420. 
about 50 persons. In addition, the Air Force Research Laboratory stations about 50 persons inside the Manzano area, 120 persons at the Phillips Optical Range, 30 persons at the High Energy Research Test Facility, and 30 persons in the USAF 5000 area. $^{5}$ The Lovelace Respiratory Research Institute (formerly Inhalation Toxicology Research Institute) lies to the southeast, with a population of about 250 .

The nearest USAF facility with a significant population is KUMSC, which is situated $1.7 \mathrm{~km}(1.1 \mathrm{mi})$ northwest of TA-V. The KUMSC has a population during normal business hours of about 150 persons and is equipped with its own environmental control system. Operations at this installation have no impact on TA-V (SNL 1995c). All other special areas or zones within KAFB (including military facilities) either have small populations or are located in a low meteorological probability zone (that is, a zone in which winds from $\mathrm{TA}-\mathrm{V}$ have a very low frequency of occurrence).

\subsubsection{TA-V Demography}

The population in and immediately adjacent to TA-V is somewhat fluid over time, rises during construction or other short-term projects, and changes dramatically between business and non-business hours. In January 1999, 204 occupants were assigned to the buildings in and near TA-V (Table 1-1). The temporary work force rarely exceeds 40 persons. All personnel are required to receive a briefing on emergency procedures before being allowed unescorted access into TA-V.

\section{$1.4 \quad$ ENVIRONMENTAL DESCRIPTION}

This section describes meteorological, hydrologic, and geologic characteristics of the site.

\subsubsection{Meteorology}

DOE (1996) requires that at least one year of valid meteorological data be used to estimate joint frequency distributions of wind speed and stability conditions. These data will be used to establish the bases for the dispersion calculations conducted to support accident analysis.

\subsubsection{General Regional Climatology and Local Meteorology}

The general weather patterns for Albuquerque and its vicinity are characteristic of highaltitude, dry continental climates, with maximum monthly rainfall occurring during the summer months. The presence of the Sandia and Manzano Mountains has a significant influence on the climate, producing inversion conditions and localized perturbations in wind patterns. Normally, sunshine is recorded for $75 \%$ or more of the daylight hours for the entire year. In other words, adverse weather conditions in this area are atypical and can be forecast with a reasonable degree of confidence.

\footnotetext{
${ }^{5}$ Information provided by Nicholas Pchelkin, Air Force Research Laboratory, 853-3677.
} 
Table 1-1. Assigned Occupancy, TA-V and Vicinity, January 1999

\begin{tabular}{|c|c|c|}
\hline $\begin{array}{l}\text { Bưildiñg } \\
\text { Number }\end{array}$ & Búfilding Description & $\begin{array}{l}\text { Number of } \\
\text { Assigned } \\
\text { Occúpants }\end{array}$ \\
\hline 6577 & Perimeter Control & 1 \\
\hline 6578 & Communications \& Defense & 1 \\
\hline 6580 & Hot Cell Facility & 15 \\
\hline 6581 & Security Services & 1 \\
\hline 6585 & Technology Support Center & 163 \\
\hline 6588 & ACRR and Gamma Irradiation & 15 \\
\hline 6591 & Reactor Control & 5 \\
\hline 6594 & Low level Counting Lab & 1 \\
\hline 6597 & Radiation Simulation & 1 \\
\hline$T 52$ & Transportable Building & 1 \\
\hline
\end{tabular}

* These numbers do not include the security force. Buildings not enumerated had no assigned occupants in January 1999.

\subsubsection{Temperature, Humidity, and Precipitation}

Normal daily minimum temperatures for winter months are about $-5^{\circ} \mathrm{C}$ to $-3^{\circ} \mathrm{C}\left(23^{\circ} \mathrm{F}\right.$ to $\left.27^{\circ} \mathrm{F}\right)$ and for the summer months, $14^{\circ} \mathrm{C}$ to $19^{\circ} \mathrm{C}\left(57^{\circ} \mathrm{F}\right.$ to $\left.66^{\circ} \mathrm{F}\right)$. Normal daily maximum temperatures are $8^{\circ} \mathrm{C}$ to $11^{\circ} \mathrm{C}\left(46^{\circ} \mathrm{F}\right.$ to $\left.52^{\circ} \mathrm{F}\right)$ in winter and $28^{\circ} \mathrm{C}$ to $33^{\circ} \mathrm{C}\left(82^{\circ} \mathrm{F}\right.$ to $\left.91^{\circ} \mathrm{F}\right)$ in summer. Thus, the approximate diurnal temperature range for both winter and summer is $14 \mathrm{C}^{\circ}$ to $16 \mathrm{C}^{\circ}\left(25 \mathrm{~F}^{\circ}\right.$ to $\left.29 \mathrm{~F}^{\circ}\right)$. Temperatures above $38^{\circ} \mathrm{C}\left(100^{\circ} \mathrm{F}\right)$ and below $-18^{\circ} \mathrm{C}$ $\left(0^{\circ} \mathrm{F}\right)$ are rare. Average values for relative humidity vary from lows of $10 \%$ to $20 \%$ to highs of $60 \%$ to $70 \%$, and these ranges can occur during any day of the year.

For the long-term record, the National Weather Service (NWS) data taken at the Albuquerque International Airport are used to determine temperature and relative humidity. The average annual rainfall for the Albuquerque area is $21.4 \mathrm{~cm}(8.4 \mathrm{in}$.$) . The lowest$ monthly precipitation typically occurs in the winter, with less than $1.3 \mathrm{~cm}(0.5 \mathrm{in}$.). The highest average monthly precipitation occurs from July to September and accounts for about half of the annual amount. Summer precipitation is usually the result of highly localized, heavy thundershowers that typically last an hour or less at any given location. The maximum precipitation recorded within a 24-hour period occurred on September 28, 1893 , when $5.74 \mathrm{~cm}\left(2.26 \mathrm{in}\right.$.) was recorded. ${ }^{6}$ Thundershower activity can result in considerable precipitation. Localized flooding may result from this concentrated activity, and water may run high in arroyos in the area.

SNL/NM precipitation and wind information varies from NWS data. Topographic features such as mountains, canyons, and arroyos influence local wind patterns across

\footnotetext{
${ }^{6}$ According to the National Weather Service, Albuquerque.
} 
SNL/NM. Canyons and arroyos tend to channel or funnel wind, whereas mountains create upslope-downslope diurnal wind flows. A more detailed climatic description for the TA-V site is given in the following section.

\subsubsection{Meteorological Measurement and Monitoring Program}

To postulate the dispersion of contaminants from accidental releases, climatic conditions throughout the SNL/NM area must be taken into consideration. The current eight-tower meteorological monitoring network at SNL/NM consists of six 10-meter towers, one 60-meter tower, and one 50-meter tower (SNL 1998). Four of the towers are within $3000 \mathrm{~m}$ of TA-V (Figure 1-5). The closest tower to TA-V (A36) is located in TA-III, just outside the southwest corner of TA-V (SNL 1998). This network has been in operation since 1994. The meteorological variables measured at A36 include wind speed and direction, temperature, relative humidity, precipitation, and barometric pressure. The standard deviation of the horizontal wind direction (sigma theta) is calculated from the one-second variations of wind direction for use in Pasquill-Gifford atmospheric stability calculations. Meteorological parameters are measured once per second, averaged, and stored as 15-minute averages. The data are continuously downloaded to a central facility computer that controls data retrieval, validation, and management. The real-time data are available in the SNL/NM Emergency Operations Center. ${ }^{7}$

Meteorological information from a rooftop monitor on Building 6577 is also available in the TA-V Emergency Operations Room. If a release were to occur, information from this monitor could be used initially to determine dispersion patterns. ${ }^{8}$ Chapter 15 of the SAR will describe the emergency preparedness program and plans.

Table 1-2 presents three-year climatic data from the A36 meteorological tower. The data

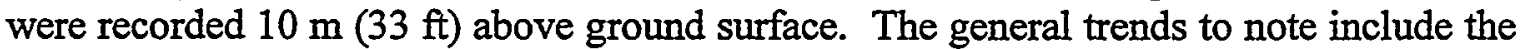
large average daily temperature range as shown by the daily maximum and minimum temperatures, the windy season that produces low relative humidities between April and June, and the warm-season precipitation pattern.

The most important implication of meteorological variation across SNL/NM is that wind variability may affect the transport and dispersion of pollutants.

Pasquill-Gifford atmospheric stability classes are calculated using the standard deviations of the horizontal wind direction. The stability stratification for the TA-V tower is given using the three-year database. Table 1-3 presents the frequency of stability and wind speed conditions that could be expected in general at TA-V.

\footnotetext{
${ }^{7}$ Maintained by Organization 7575, Environmental \& Emergency Management. Information obtained from R. Deola, Org. 7575.

${ }^{8}$ Information obtained from R. Deola, Org. 7575.
} 


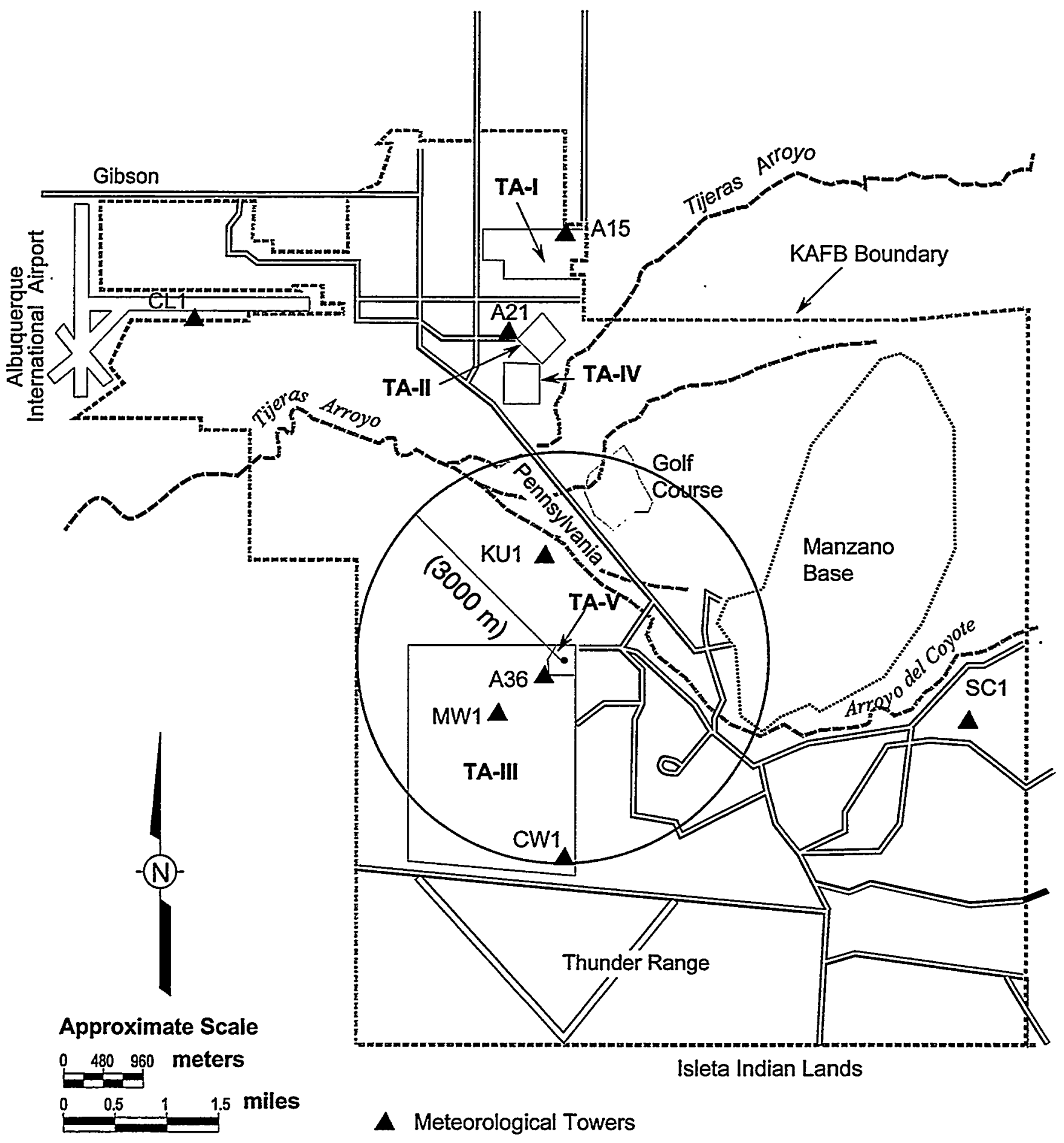

Figure 1-5. Meteorological Monitoring Stations. 
Table 1-2. Three-Year Climatological Data for the A36 Tower

\begin{tabular}{|c|c|c|c|c|c|c|c|c|c|c|c|c|}
\hline \multirow[t]{2}{*}{$\begin{array}{l}\text { Para- } \\
\text { meter: }\end{array}$} & \multicolumn{12}{|c|}{$\therefore$ Month } \\
\hline & Jan & Feb & Mar & Apr & May & Jun & Jul & Aug & Sep & Oct & Nov & Dec \\
\hline \multicolumn{13}{|c|}{ Temperature $\left({ }^{\circ} \mathrm{C}\right)$} \\
\hline $\begin{array}{l}\text { Daily } \\
\text { Maximum }\end{array}$ & 9.5 & 13.5 & 16.1 & 20.0 & 27.8 & 31.6 & 32.9 & 31.5 & 26.2 & 20.6 & 14.3 & 10.3 \\
\hline $\begin{array}{l}\text { Daily } \\
\text { Minimum } \\
\end{array}$ & -2.4 & 0.5 & 2.2 & 5.5 & 11.3 & 16.7 & 18.5 & 18.2 & 13.1 & 6.8 & 1.1 & -1.3 \\
\hline Average & 3.7 & 7.2 & 9.3 & 13.0 & 19.6 & 24.3 & 25.5 & 24.4 & 19.8 & 14.7 & 8.6 & 4.8 \\
\hline \multicolumn{13}{|c|}{ Extremes $\left({ }^{\circ} \mathrm{C}\right)$} \\
\hline $\begin{array}{l}\text { Record } \\
\text { High }\end{array}$ & 19.8 & 20.8 & 25.0 & 29.8 & 34.4 & 39.3 & 38.4 & 36.0 & 34.1 & 28.3 & 22.5 & 19.5 \\
\hline Record Low & -10.1 & -11.2 & -6.1 & -2.6 & 3.1 & 7.8 & 11.5 & 14.8 & 3.5 & -4.5 & -7.6 & -13.6 \\
\hline \multicolumn{13}{|c|}{ Relative humidity (\%) } \\
\hline & 46.1 & 43.4 & 39.6 & 30.1 & 27.9 & 28.7 & 35.8 & 47.6 & 48.4 & 42.2 & 48.9 & 50.6 \\
\hline \multicolumn{13}{|c|}{ Precipitation (Centimeters) } \\
\hline Average & 0.7 & 0.9 & 0.7 & 0.4 & 2.5 & 1.6 & 2.1 & 7.3 & 3.3 & 4.0 & 1.9 & 0.8 \\
\hline Maximum & 1.3 & 1.5 & 1.5 & 1.2 & 7.2 & 3.7 & 2.5 & 11.6 & 4.4 & 7.6 & 3.8 & 2.1 \\
\hline Minimum & 0.00 & 0.5 & 0.1 & 0.00 & 0.00 & 0.1 & 1.5 & 3.0 & 2.0 & 0.00 & 0.2 & 0.00 \\
\hline $\begin{array}{l}\text { 24-hour } \\
\text { Maximum }\end{array}$ & 1.0 & 1.1 & 0.4 & 0.6 & 1.7 & 1.6 & 2.4 & 3.5 & 1.7 & 2.8 & 1.9 & 1.1 \\
\hline \multicolumn{13}{|c|}{ Wind (Meters per Second) } \\
\hline $\begin{array}{l}\text { Monthly } \\
\text { Average }\end{array}$ & 3.3 & 3.6 & 4.1 & 4.4 & 4.5 & 4.1 & 3.9 & 3.5 & 3.3 & 3.6 & 3.3 & 2.9 \\
\hline $\begin{array}{l}\text { 24-hour } \\
\text { Maximum }\end{array}$ & 8.5 & 8.1 & 11.2 & 9.7 & 10.6 & 9.1 & 6.6 & 6.4 & 9.1 & 11.6 & 7.5 & 7.1 \\
\hline $\begin{array}{l}\text { Maximum } \\
\text { Gust }\end{array}$ & 25.3 & 22.1 & 25.3 & 23.7 & 25.3 & 26.9 & 26.9 & 27.7 & 19.7 & 25.3 & 23.7 & 26.9 \\
\hline \multicolumn{13}{|c|}{ Barometric Pressure (Millibars) } \\
\hline & 838.2 & 836.9 & 834.8 & 832.4 & 830.7 & 832.2 & 833.7 & 834.5 & 835.4 & 835.2 & 837.0 & 837.6 \\
\hline
\end{tabular}


Table 1-3. Average Wind Speeds (WS) for Each Stability Class and Frequencies of Stabilities for TA-V

\begin{tabular}{|c|c|c|c|c|c|c|c|c|c|}
\hline $\begin{array}{l}\text { Stability } \\
\text { Clas8 }\end{array}$ & Ave Ws & $w s<1$ & WS.1.2 & Ws 2-3 & Ws 34 & Ws 4.5 & Wis 5-6 & ws $>6$ & Total \% \\
\hline $\begin{array}{l}\text { A (1) } \\
\text { Extremely } \\
\text { Unstable }\end{array}$ & $2.11 \mathrm{~m} / \mathrm{s}$ & $0.43 \%$ & $4.02 \%$ & $7.05 \%$ & 0 & 0 & 0 & 0 & 11.5 \\
\hline $\begin{array}{l}\text { B (2) } \\
\text { Moderately } \\
\text { Unstable }\end{array}$ & $2.00 \mathrm{~m} / \mathrm{s}$ & $0.09 \%$ & $0.92 \%$ & $1.72 \%$ & $5.40 \%$ & 0 & 0 & 0 & 8.13 \\
\hline $\begin{array}{l}C(3) \\
\text { Slightly } \\
\text { Unstable }\end{array}$ & $3.83 \mathrm{~m} / \mathrm{s}$ & $0.07 \%$ & $0.84 \%$ & $1.52 \%$ & $1.89 \%$ & $3.29 \%$ & $1.68 \%$ & 0 & 9.28 \\
\hline $\begin{array}{l}D(4) \\
\text { Neutral }\end{array}$ & $5.10 \mathrm{~m} / \mathrm{s}$ & $0.25 \%$ & $4.09 \%$ & $7.30 \%$ & $6.28 \%$ & $3.84 \%$ & $4.59 \%$ & $14.25 \%$ & 40.59 \\
\hline $\begin{array}{l}\text { E (5) } \\
\text { Slightly } \\
\text { Stable }\end{array}$ & $3.01 \mathrm{~m} / \mathrm{s}$ & $0.45 \%$ & $4.24 \%$ & $5.76 \%$ & $6.88 \%$ & $4.85 \%$ & 0 & 0 & 22.18 \\
\hline $\begin{array}{l}F(6) \\
\text { Moderately } \\
\text { Stable }\end{array}$ & $1.59 \mathrm{~m} / \mathrm{s}$ & $1.22 \%$ & $4.97 \%$ & $2.13 \%$ & 0 & 0 & 0 & 0 & 8.32 \\
\hline
\end{tabular}

\subsubsection{Local Transport and Dispersion}

Wind patterns differ noticeably across the SNL site, depending on the strength and location of synoptic systems and the specific location's proximity to the mountains and foothills. The Manzano Mountains and Tijeras Arroyo are two topographic features that influence transport and dispersion at SNL/NM. Tijeras Canyon acts as a funnel for east winds, while the mountains create upslope-downslope diurnal wind patterns. Daytime winds blow from the valley upslope to the mountains, and winds at night blow downslope from the mountains toward the valley. Day and night windroses for 1997 are shown in Figure 1-6.

Current and historical meteorological monitoring-network data confirm that under nighttime conditions, cold air from the mountains typically flows downward into the canyons and arroyos and fans onto the flat terrain. These cold-air-drainage winds can be very shallow, with depths occasionally less than 50 or $100 \mathrm{~m}$ (164 to $328 \mathrm{ft}$ ). In addition, nocturnal cooling complicates the area's temperature-inversion profile.

The result is that pollutants are trapped below the inversion and transported generally toward Tijeras Arroyo, which acts as a confluence zone for air on each side of the arroyo. Results from two smoke tests conducted in March 1957 also confirm that transport winds from TA-V will generally blow toward, but not across, Tijeras Arroyo prior to temperature-inversion breakup (Olson et al. 1979). Under average conditions at night, when general worst-case dispersion exists, Tijeras Arroyo acts as a confluence zone 


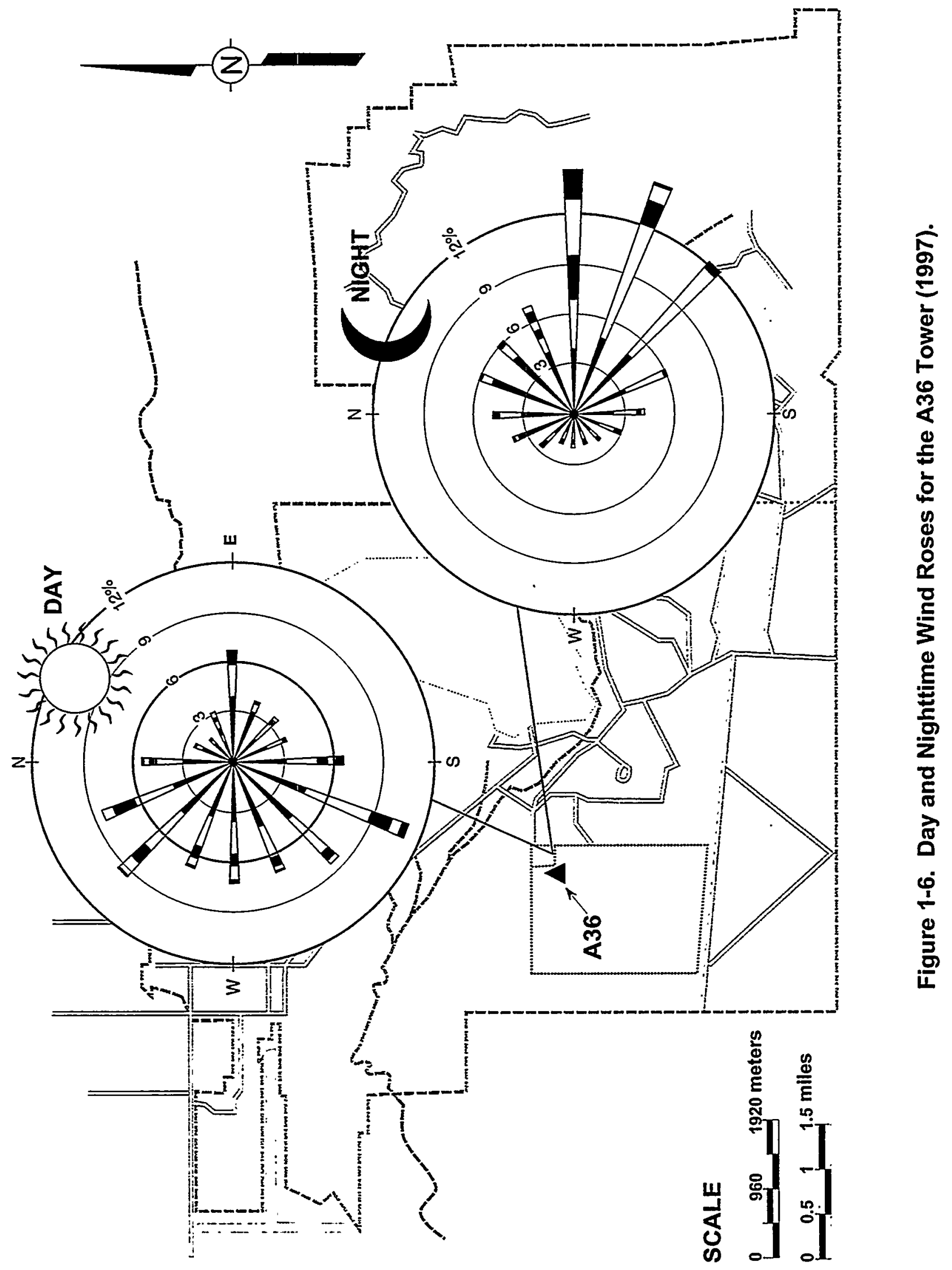


where transported material would flow toward and then be trapped in down-canyon transport, away from populated areas. Tijeras Arroyo acts as an effective barrier at night to limit northward or southward transport across the arroyo.

\subsubsection{Meteorological Data for Accident Release}

For routine air emissions releases, the CAP88-PC computer code (EPA 1995) is used to evaluate dose to the public in accordance with 40 CFR Part 61 . Wind information from the existing meteorological monitoring network is compiled and tabulated as STARDECKS (Doty et al. 1976) for direct input into CAP88-PC. Average temperature and precipitation for the evaluated year are also taken from the network.

For accidental releases, real-time meteorology would be used to calculate transport and dispersion. The HOTSPOT Health Physics code (Homann 1994) is used in the SNL/NM Emergency Operations Center. The Atmospheric Release Advisory Code (ARAC; Sullivan 1993) may be consulted for larger source-term releases. In addition, hand calculation of dispersion factors can also be performed using the Workbook of Atmospheric Dispersion Estimates (Turner 1969).

For postulated accident releases, the MELCOR Accident Consequence Code System Version 2 (MACCS2; Chanin and Young 1997) computer code is used. MACCS2 incorporates site-specific meteorological data that have been compiled and extracted from the meteorological data recorded by the Clean Air Network (CAN) system (SNL 1998). MACCS2 has been used to calculate dispersion patterns for this Preliminary Safety Analysis Report (PSAR). The MACCS2 radiological consequence modeling results are presented in Chapter 3.

\subsubsection{Hydrology}

Since KAFB has been in operation, surface water in the KAFB region has generally flowed southwest, through several major and many small unnamed arroyos, to the Rio Grande. However, groundwater flow directions have recently changed considerably from the southwesterly flow direction reported for KAFB by Bjorklund and Maxwell (1961). This change in flow direction to the north and northwest is believed to be the result of groundwater pumping in excess of recharge by KAFB and by nearby city of Albuquerque supply wells. Pumping from these well fields has created a groundwater depression along the western and northern boundaries of KAFB. This depression, extending as far south as Isleta Pueblo, is probably a result of preferential flow through highly conductive ancestral Rio Grande deposits that are the primary aquifer material in this area (SNL 1998).

\subsubsection{Surface Drainage}

On the western side of the Rio Grande, the ground surface slopes generally to the southeast and toward the river at about 9.4 to $19 \mathrm{~m} / \mathrm{km}$ (50 to $100 \mathrm{ft} / \mathrm{mi})$. The west drainage area is described by a zone extending westward from the river about $4.8 \mathrm{~km}(3 \mathrm{mi})$ and confined by a north-south trending terrace that rises about $180 \mathrm{~m} \mathrm{(600} \mathrm{ft).} \mathrm{Beyond} \mathrm{this}$ 
zone, drainage essentially follows cut terraces that parallel the river. The eastern side of the river, referred to as the East Mesa, where SNL/KAFB is located, has a generally westerly-southwesterly ground-surface slope ranging from about $47 \mathrm{~m} / \mathrm{km}(250 \mathrm{ft} / \mathrm{mi})$ near the mountains to $3.8 \mathrm{~m} / \mathrm{km}(20 \mathrm{ft} / \mathrm{mi})$ near the river. The distance between the base of the mountains and the river varies, but is roughly $17 \mathrm{~km}(11 \mathrm{mi})$.

TA-V sits on a mesa bounded on the east by the Manzano Mountains, on the west by the Rio Grande, on the north by Tijeras Arroyo, and on the south by Hell's Canyon Wash. The slope of the mesa declines gradually toward the Rio Grande. The terrain is characterized by numerous small canyons that have been cut through the mesa by drainage from the mountains. Topography near TA-V is dominated by Tijeras Canyon, about $3 \mathrm{~km}$ (2 mi) to the north.

Arroyo del Coyote, an arroyo in Tijeras Canyon of particular importance to TA-V during precipitation events, is about $0.8 \mathrm{~km}(0.5 \mathrm{mi})$ east of the complex, running southeast to northwest and emptying into Tijeras Canyon (Figure 1-2). During heavy precipitation events east of TA-V, Arroyo del Coyote effectively collects runoff from the mountains and diverts surface flow away from TA-V. Therefore, surface flows that could affect TA-V are limited to the amount of runoff that collects between TA-V and the arroyo. The heaviest precipitation to date in this area has not produced flooding in TA-V. Flooding is discussed in greater detail in Section 1.5.3. All precipitation occurring in areas to the north, south, and west of $\mathrm{TA}-\mathrm{V}$ is drained away from the complex by the natural surface slope and, therefore, does not constitute a threat. General flooding of the site is extremely unlikely, and, on the basis of historical evidence, is not apt to result from natural phenomena.

Most runoff from TA-V flows west onto TA-III as overland flow and in natural and manmade surface drainage features. The remainder flows into two storm sewers in the northern portion of TA-V. Both storm sewers discharge to open channels within, and just north of, TA-III. Drainage from TA-III is to the west onto undeveloped portions of $\mathrm{KAFB}$ and then into playas on undeveloped state land. At present there is no requirement for monitoring runoff from TA-V because the runoff flowing from that area is not discharged to "waters of the United States" (SNL 1999b).

\subsubsection{Soil Characteristics}

TA-V falls within the Upper Llano de Manzano geomorphic subprovince, and Arroyo del Coyote, at least the part that drains TA-V, falls within the Tijeras Arroyo geomorphic subprovince. Soils associated with the Arroyo del Coyote valley floor and embankments and the northeast section of TA-V are of the Embudo and Tijeras Series. These soils are generally well drained, have moderate permeability, and have high potential for surface erosion. Water percolates rapidly through the fine sandy loam associated with the Arroyo del Coyote valley floor (DOE 1999). In addition to the Embudo and Tijeras Series, TA-V has soils of the Madurez Series (SNL 1999c). Water percolates very rapidly through Madurez loamy fine sand and Madurez Wink association soils. The moderate to rapid percolation in these soils reduces excess runoff that creates flooding. Major soil classifications for TA-V are described in Table 1-4. 
Table 1-4. Major Soil Classifications for TA-V and Arroyo del Coyote Drainage Area (USDA 1977)

\begin{tabular}{|c|c|c|c|c|c|}
\hline Series & Type & Subphovince & $\begin{array}{l}\text { Percent } \\
\text { Slope }\end{array}$ & Runoff & $\begin{array}{l}\text { Sóil and Water } \\
\text { Erósion Hazard }\end{array}$ \\
\hline \multirow[t]{2}{*}{ Embudo } & $\begin{array}{l}\text { Embudo gravely } \\
\text { fine sandy loam }\end{array}$ & 1,3 & 0 to 5 & Medium & $\begin{array}{l}\text { Water erosion- } \\
\text { moderate }\end{array}$ \\
\hline & $\begin{array}{l}\text { Embudo Tijeras } \\
\text { Complex }\end{array}$ & 1 & 0 to 9 & Medium & $\begin{array}{l}\text { Water erosion- } \\
\text { moderate }\end{array}$ \\
\hline Tijeras & $\begin{array}{l}\text { Tijeras gravely fine } \\
\text { sandy loam }\end{array}$ & 1,3 & 1 to 5 & Moderate & $\begin{array}{l}\text { Water erosion- } \\
\text { moderate }\end{array}$ \\
\hline \multirow[t]{2}{*}{ Madurez } & $\begin{array}{l}\text { Madurez loamy } \\
\text { fine sand }\end{array}$ & 1,3 & 1 to 5 & Slow & $\begin{array}{l}\text { Soil blowing- } \\
\text { severe }\end{array}$ \\
\hline & $\begin{array}{l}\text { Madurez-Wink } \\
\text { association }\end{array}$ & 1,3 & 1 to 5 & Slow & $\begin{array}{l}\text { Soil blowing- } \\
\text { moderate to } \\
\text { severe }\end{array}$ \\
\hline
\end{tabular}

* Subprovinces: 1-Tijeras Arroyo; 3-Upper Llano de Manzano.

\subsubsection{Subsurface Characteristics}

Groundwater in the KAFB area occurs within saturated, unconsolidated geologic material and fractured and porous bedrock. The groundwater beneath KAFB is part of an interconnected series of water-bearing geologic units within the Albuquerque Basin that form the Albuquerque-Belen Basin aquifer. The principal sedimentary fill of the AlbuquerqueBelen Basin is the Santa Fe Group, consisting of gravel, sand, silt, and clay (Thorne et al. 1993). The potentiometric surface and direction of groundwater flow for the regional groundwater system is shown in Figure 1-7 (SNL 1998).

The local (SNL/NM) groundwater system has three hydrogeologic regions, whose locations are roughly delineated by the geologic fault system that bisects KAFB. (This fault system is discussed in detail in Section 1.5.2.3).

The first hydrogeologic area underlies all the SNL/NM TAs and lies generally west of the fault system. Groundwater flow is generally north to northwest. Groundwater levels have been declining at rates of 6 to $91 \mathrm{~cm}(0.2$ to $3.0 \mathrm{ft})$ per year in this area. Hydraulic conductivities range from less than $0.03 \mathrm{~m} / \mathrm{d}(0.1 \mathrm{ft} / \mathrm{d})$ to more than $30.5 \mathrm{~m} / \mathrm{d}(100 \mathrm{ft} / \mathrm{d})$. The depth of the unsaturated zone ranges between $149 \mathrm{~m}(488 \mathrm{ft})$ and $162 \mathrm{~m}(530 \mathrm{ft})$ in $\mathrm{TA}-\mathrm{V}$, depending on the location of the well measured.

Hydraulic conductivities are highly variable in the area of the fault system, the hydrogeologic region just east of TA-III and TA-V. These conductivities range from $0.0009 \mathrm{~m} / \mathrm{d}$ $(0.003 \mathrm{ft} / \mathrm{d})$ in the bedrock to nearly $46 \mathrm{~m} / \mathrm{d}(150 \mathrm{ft} / \mathrm{d})$ in the alluvial material. Depth to groundwater also varies greatly, from zero feet along the Arroyo del Coyote south of Manzano Base, to $152 \mathrm{~m}$ (500 ft) near the southeast corner of TA-III (DOE 1999). 


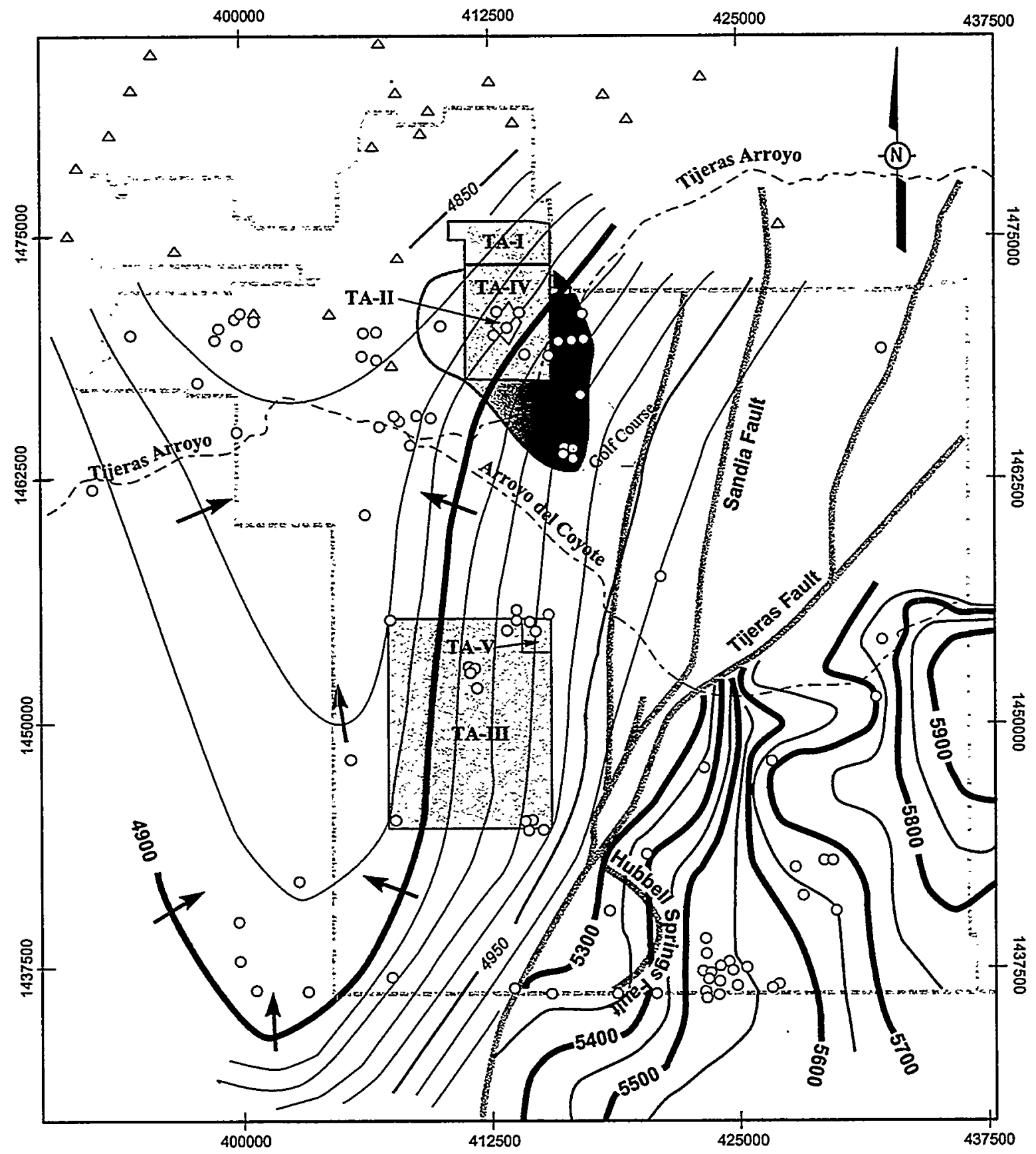

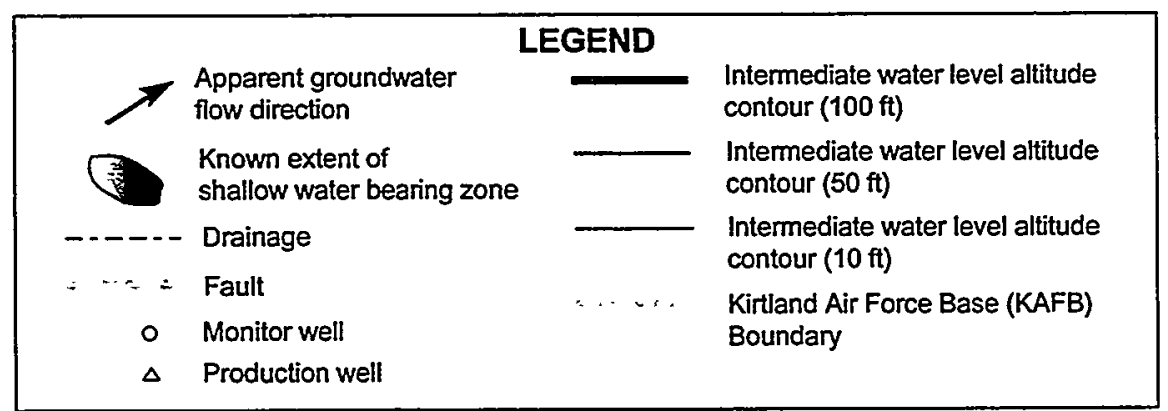

SCALE

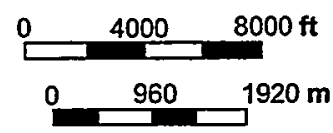

Figure 1-7. Potentiometric Surface and Groundwater Flow Directions for the Regional Groundwater System. 
The third hydrogeologic area is characterized by bedrock aquifers east of the faulted zone, although in some places a thin layer of groundwater-containing alluvial material overlies the bedrock. Depth to groundwater varies $46 \mathrm{~m} / \mathrm{d}(150 \mathrm{ft} / \mathrm{d})$ near the Hubbell Springs Fault to near zero feet along portions of Arroyo del Coyote.

Monitor wells located in TA-V and in the area defined by the $3000-\mathrm{m}$ radius centered on $\mathrm{TA}-\mathrm{V}$ are shown in Figure 1-8. Water levels are measured monthly, and water quality is measured quarterly for volatile organic compounds (VOCs) and nitrate plus nitrite. In addition, samples taken during some quarters are analyzed for the full suite of analytes, including VOCs, nitrate plus nitrite, semivolatile organic compounds, Resource Conservation and Recovery Act (RCRA) metals plus beryllium, major anions and cations, tritium, gross alpha and beta, and gamma spectroscopy (SNL 1997a).

\subsubsection{TA-V Water Supply}

The groundwater beneath SNL/NM and adjacent areas is the source of drinking water for SNL/NM, KAFB, and portions of the city of Albuquerque. Several water-supply wells for the city of Albuquerque and KAFB are near the northern boundary of KAFB.

Water from the main KAFB water system supplies the TA-III/TA-V water distribution system. The primary water sources are a 1-million-gal storage tank and a 3.5-million-gal storage tank located approximately $5.6 \mathrm{~km}(3.5 \mathrm{mi})$ north of TA-III/TA-V. Water is conveyed from these tanks to TA-III/TA-V through $25.4-\mathrm{cm}$ (10-in.) and 35.6-cm (14-in.) water lines that are cross-connected within these two TAs. In addition, a 700,000-gal storage tank located east of TA-III provides temporary backup to the TA-III/TA-V water distribution systems in the event that the supply from the primary water sources is disrupted.

\subsubsection{Geology}

This section provides general geologic information concerning the site.

\subsubsection{General Data}

SNL/NM is situated in the eastern portion of the Albuquerque-Belen Basin. This basin, one of the largest in a series of basins that trend to the north in the Rio Grande trough, is about $145 \mathrm{~km}(90 \mathrm{mi})$ long and $48 \mathrm{~km}(30 \mathrm{mi})$ wide. The basin is bounded by the SandiaManzanita-Manzano Mountains on the east, the Lucero uplift and Puerco plateau on the west, and the Nacimiento uplift on the north. The southern boundary is defined by the Socorro channel. The basin is widest in the Albuquerque area and constricted to the south by the San Acacia channel and to the north by the Cerrillos trend.

Large-scale faulting, deepening of the basin, and tilting of the mountain zones occurred in late Miocene time. Since then, basin deposits have been laid down in a sequence of complex layers (SNL 1995c). 


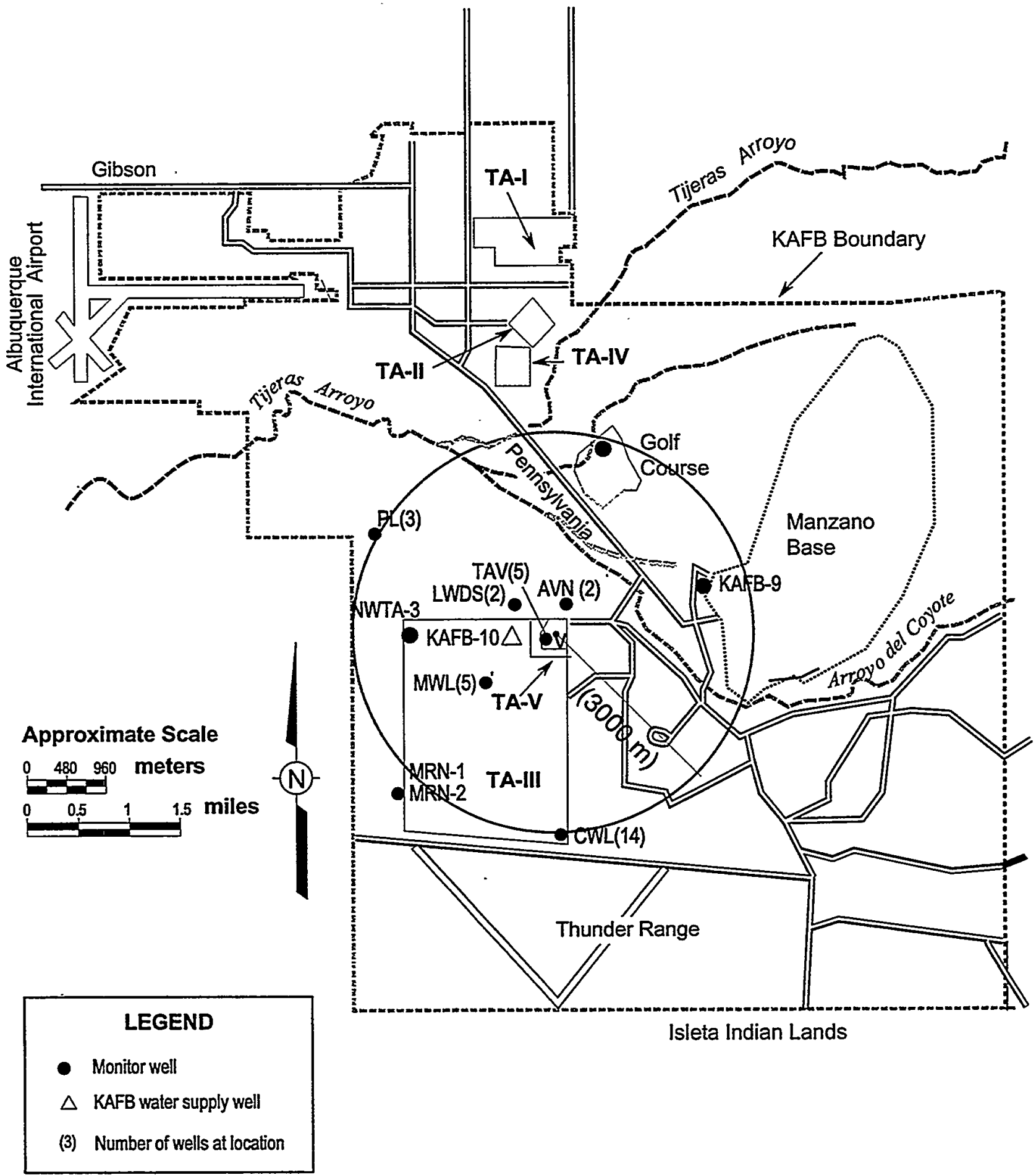

Figure 1-8. Monitor Well Locations in the Vicinity of TA-V. 


\subsubsection{Basin and Range Structures}

The majority of the basin is composed of poorly consolidated sediments eroded from the surrounding mountain areas following the faulting and structural changes that occurred in late Miocene time. The upper part of the basin is a complex sequence of gravel, sand, silt, clay, and caliche deposits known as the Santa Fe Group. Underlying these deposits are sedimentary rocks indicated by gravity and aeromagnetic mapping to extend down to about $3000 \mathrm{~m}(10,000 \mathrm{ft})$ below sea level, or about $4600 \mathrm{~m}(15,000 \mathrm{ft})$ below ground level. These sedimentary rocks rest on a bed of Precambrian rocks that underlie the entire basin and then lift up to form the western plateaus and eastern mountains.

The Sandia Mountains rise about $1500 \mathrm{~m}(5000 \mathrm{ft})$ above the land surface of the basin, giving a total difference of elevation between the Precambrian rocks in the basin and mountains of roughly $6100 \mathrm{~m}(20,000 \mathrm{ft})$. On the west side, Precambrian rocks lie at about sea level, with sedimentary rock overlying them to a depth of about $1500 \mathrm{~m}$ (5000 ft) above sea level (SNL 1995b).

\subsubsection{Site Geology}

TA-V is underlain by formations of the Santa Fe Group of Quaternary and Tertiary age. The Santa Fe Group is in turn underlain by formations of Permian, Pennsylvanian, and Precambrian age. These older rocks crop out in the horst about $800 \mathrm{~m}$ ( $0.5 \mathrm{mi})$ east of the site and also in the mountains farther east. Thin deposits of recent alluvium occur in the arroyos in the area.

The alluvium consists of unconsolidated sand, gravel, and silt with a maximum thickness of 5 to $6 \mathrm{~m} \mathrm{(15}$ to $20 \mathrm{ft}$ ). This material is largely derived from the granite and metamorphosed rocks of Precambrian age that are exposed to the east. Generally, the porosity and permeability of this alluvial material are high, allowing relatively free movement of water. The Santa Fe Group comprises material similar to the alluvium, but much of the material has come into the area from the north, and there is a slightly greater degree of consolidation of some beds.

The Santa Fe Group was deposited by streams and, consequently, there are rapid lateral and vertical changes in the character of the sediments. Individual beds are generally lenticular, but some extend for considerable distances as channel deposits. These long, narrow channel deposits are generally oriented in a northeast-southwest direction. The thickness of the Santa Fe Group beneath the site is not known, but is probably more than $150 \mathrm{~m}(500 \mathrm{ft})$. The porosity and permeability of the Santa $\mathrm{Fe}$ Group as a unit in this area are generally high; however, the permeability of individual beds or lenses of silt or clay is quite low.

The pre-Tertiary rocks that underlie the Santa Fe Group consist of sandstones, siltstones, limestones, and metamorphosed sediments lying on top of granite. These rocks are well consolidated and less porous and permeable than the rocks of the Santa Fe Group. The thickness of these rocks appears to be at least $6700 \mathrm{~m}(22,000 \mathrm{ft})$. 
Rocks of Precambrian age are exposed about $800 \mathrm{~m}(0.5 \mathrm{mi})$ east of the site in a northeast-southwest upfaulted block or horst about $300 \mathrm{~m}(980 \mathrm{ft})$ wide. The fault bordering the west side of the horst has a displacement of at least $180 \mathrm{~m}(590 \mathrm{ft})$ and probably much more, as indicated by the $200 \mathrm{~m}$ (650 ft) of clay, sand, and gravel penetrated by the Sandia well in the northwest quadrant of the southwest quarter of Section 15, Township 9 North, Range 4 East, about $3 \mathrm{~km} \mathrm{(2} \mathrm{mi)} \mathrm{northeast} \mathrm{of} \mathrm{TA-V.}$

The small hills east of the horst are deformed beds of the Santa Fe Group along the west side of a downfaulted block, or graben. Any faults that may be present at TA-V are masked by an alluvial fan.

Table 1-5 summarizes the stratigraphy of TA-V.

\subsection{NATURAL HazARDS}

This section identifies natural phenomena events and the likelihood that they will affect operations at TA-V.

\subsubsection{Tornadoes}

The mean annual frequency of tornado occurrences in New Mexico ranged from a minimum of 0.2 to a maximum of 1.1 between 1953 and 1962, depending on location (Thom 1963). Statistically, the highest frequency has been observed in the eastern half of the state. For the western half of the state, generally demarcated by the Rio Grande and the mountain ranges that parallel it on the east side, tornado frequencies are 0.3 or less.

In the Albuquerque area, which lies west of the Sandia and Manzano Mountains, only one tornado has occurred, in $1985 .^{9}$ Damage was very light and no official wind readings were made.

In addition, one funnel cloud has been observed. This cloud was reported in the Four Hills area of Albuquerque about $6 \mathrm{~km}(3.7 \mathrm{mi})$ to the north of the TA-V site on KAFB. Based on the climatological records available, Albuquerque can be classified as a region of low tornado occurrence with an annual frequency of 0.1 or less. Tornado severity within the Albuquerque area would be expected to be significantly less than that in the Midwest because the meteorological conditions required to produce a severe tornado rarely occur.

${ }^{9}$ According to the National Weather Service, Albuquerque. 
Table 1-5. Stratigraphy of TA-V

\begin{tabular}{|c|c|c|c|c|}
\hline Age & Fómation or Group & $\begin{array}{l}\text { Thickness } \\
(m)\end{array}$ & $\therefore$ Character & $\begin{array}{l}\text { Water-Bearing. } \\
\text { Characteristics }\end{array}$ \\
\hline Recent & Alluvium & 4 to 6 & Sand and gravel & $\begin{array}{l}\text { Unsaturated, but generally } \\
\text { highly porous and permeable }\end{array}$ \\
\hline $\begin{array}{l}\text { Quaternary } \\
\text { and Tertiary }\end{array}$ & Santa Fe Group & 0 to 3000 & $\begin{array}{l}\text { Sand, gravel, and } \\
\text { silt; generally } \\
\text { unconsolidated }\end{array}$ & $\begin{array}{l}\text { Permeable and porous; the } \\
\text { only important aquifer in the } \\
\text { area }\end{array}$ \\
\hline Permian & $\begin{array}{l}\text { San Andres Formation, } \\
\text { Glorieta Sandstone, } \\
\text { Yeso Formation, Abo } \\
\text { Formation }\end{array}$ & 850 & $\begin{array}{l}\text { Sandstone, } \\
\text { siltstone, and } \\
\text { limestone }\end{array}$ & $\begin{array}{l}\text { Low permeability and porosity, } \\
\text { but some water occurs in } \\
\text { Glorieta sandstone; most } \\
\text { water in these formations } \\
\text { occurs in cracks and joints }\end{array}$ \\
\hline Pennsylvanian & Magdalena Group & 240 to 270 & $\begin{array}{l}\text { Siltstone, limestone, } \\
\text { and sandstone }\end{array}$ & $\begin{array}{l}\text { Low permeability and porosity; } \\
\text { most, if not all, water occurs in } \\
\text { cracks and joints }\end{array}$ \\
\hline Precambrian & $\begin{array}{l}\text { Seviletta Formation, } \\
\text { Upper Metaclastic } \\
\text { Series, Lower } \\
\text { Metaclastic Series, } \\
\text { Greenstone complex } \\
\text { intrusives }\end{array}$ & $5500+$ & $\begin{array}{l}\text { Metamorphosed } \\
\text { sedimentary and } \\
\text { pyroclastic rock and } \\
\text { intrusives, and } \\
\text { granites and } \\
\text { pegmatites }\end{array}$ & $\begin{array}{l}\text { Low permeability, very low } \\
\text { porosity; all water in these } \\
\text { formations occurs in cracks } \\
\text { and joints }\end{array}$ \\
\hline
\end{tabular}

\subsubsection{Earthquakes}

This section covers seismicity in the vicinity of Albuquerque.

\subsubsection{Seismic History}

Ten absolute-gravity stations in the vicinity of SNL/KAFB are maintained by the National Geodetic Survey and the Defense Mapping Agency. The Albuquerque area is located in Seismic Zone 2B (Figure 1-9), which is defined as a region that can be expected to receive moderate damage from earthquakes. Seismically, the Albuquerque area is characterized as a region of high activity but relatively low magnitude and intensity.

Based on available information, most earthquakes recorded in New Mexico have occurred along the Rio Grande trough, with the region between Albuquerque and Socorro (100 km [62 mi] apart) exhibiting the highest concentration, accounting for about $90 \%$ of the recorded earthquakes between 1890 and 1960. Instrumented seismic records for New Mexico beginning in 1960 indicate that the pattern of seismic activity for earthquakes of Richter magnitude 2.7 or greater has shifted, such that the center of activity is in the northeast quadrant of the state. As far as can be determined from geologic data, there have been no intensive earthquakes in the Albuquerque area within recent geologic history. However, several earthquakes centered near Albuquerque during the past 20 


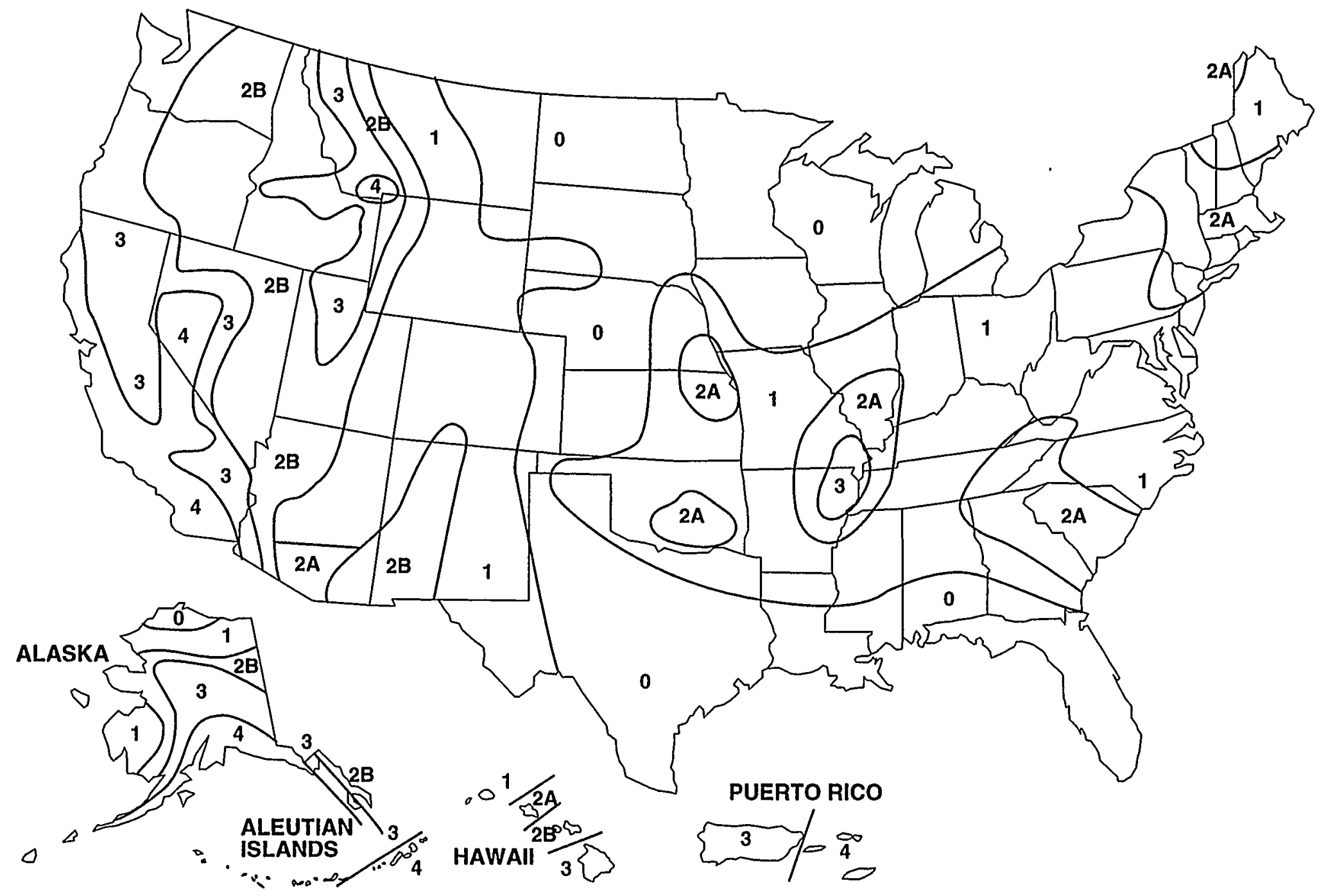

Figure 1-9. Seismic Risk Map of the United States and Puerto Rico (ICBO 1994). 
years have recorded Richter magnitudes of 2.7 or greater (Sanford et al. 1972). Earthquakes with magnitudes of 3.0 or greater for the period 1986 through 1994 are shown in Figure 1-10.

Perhaps the strongest shock of the century in the Albuquerque area was that of January 4, 1971, which registered a magnitude 4.7 on the Richter scale. The largest shock predicted in New Mexico in a 100-year time period is of magnitude 6.0 on the Richter scale (SNL 1995a). Merrick (1998) analyzed seismic loading of the jib crane and hot cell.

\subsubsection{Albuquerque Fault Zones}

The entire length of the Rio Grande trough is characterized by complex fault zones along the trough boundaries. The faults are generally characterized by major lines of discontinuity that define large blocks of substructure that have shifted with respect to each other, primarily vertically. Most of the faults lie along the base of the mountains on each side of the trough.

In general, the characteristics of the trough within the Albuquerque-Belen Basin are essentially the same as for the Rio Grande trough. The basin is bounded on both sides by a complex fault structure characterized by large vertical displacements between adjacent blocks; in some areas, evidence can be found indicating horizontal displacement. Faulting has been determined to exist at subsurface levels, and on the east side at least four zones of subsurface faults have been identified.

\subsubsection{Fault Zones in the Vicinity of TA-V}

Three zones of faulting on the west slope of the Sandia and Manzano Mountains have been identified in the vicinity of Manzano Base and the SNL. TAs: the Tijeras Fault, the Sandia Fault, and the Hubbell Springs Fault. The Tijeras and Sandia Faults converge near the south end of TA-III into the Hubbell Springs Fault (Figure 1-11).

The Tijeras Fault is a strike-slip fault of Paleozoic age expressed by southwesterly movement of the northern block (left lateral). The fault has been traced as far north as Madrid, New Mexico, and trends southwesterly through Tijeras Canyon and along Four Hills just north of KAFB. The two other faults on KAFB are the Tertiary age Hubbell Springs and Sandia Faults. These faults are north-south trending, down-to-the-west, en echelon normal faults (Lozinsky and Teford 1991).

The Sandia Fault is thought to be the primary boundary between the Sandia Mountains and the Albuquerque Basin. The Hubbell Springs Fault extends northward from Socorro County, New Mexico, into the southern portion of KAFB. The Hubbell Springs Fault is particularly important to the AHCF and other facilities in TA-V/TA-III because it has been active as recently as 1931-35, when earth movement along the fault shut off the water flow from nearby springs. An analysis of this potential hazard is presented in Chapter 3. 


\begin{tabular}{|c|c|c|c|c|c|c|c|c|c|c|}
\hline $\begin{array}{l}\text { LAT/ } \\
\text { LONG }\end{array}$ & $107^{\circ} 20^{\prime}$ & $107^{\circ} 10^{\prime}$ & 10700' & $\begin{array}{c}106^{\circ} 50^{\circ} \\
\end{array}$ & $106^{\circ} 40^{\prime}$ & $106^{\circ} 30^{\prime}$ & $\begin{array}{c}106^{\circ} 20^{\prime} \\
\vdots\end{array}$ & $106^{\circ} 10^{\prime}$ & $106^{\circ} 00^{\prime \prime}$ & $\begin{array}{l}\text { LATI } \\
\text { LONG }\end{array}$ \\
\hline $35^{\circ} 40^{\circ}$ & & & & & & & & $\begin{array}{l}\square \\
\text { SFE }\end{array}$ & & $35^{\circ} 40^{\prime}$ \\
\hline $35^{\circ} 30^{\prime}$ & & & & & & & & & & $35^{\circ} 30^{\prime}$ \\
\hline $35^{\circ} 20^{\circ}$ & & & & & & & & & & $35^{\circ} 20^{\prime \prime}$ \\
\hline $\begin{array}{c}35^{\circ} 10^{\circ} \\
\because \\
\vdots\end{array}$ & & & & & & & & & & $\begin{array}{c}35^{\circ} 10^{\circ} \\
\vdots\end{array}$ \\
\hline $\begin{array}{c}35^{\circ} 00^{2} \\
\end{array}$ & $\begin{array}{l}\square^{\circ} \\
\text { LAG }\end{array}$ & & & & $\begin{array}{l}\square \\
A B Q\end{array}$ & & & & - & $35^{\circ} 00^{\prime}$ \\
\hline $34^{\circ} 50^{\prime} \ldots$ & & & & & & & & & $\begin{array}{l}\square \\
\text { EST }\end{array}$ & $\begin{array}{c}34^{\circ} 50^{\prime} \\
\ddots \\
\ddots\end{array}$ \\
\hline 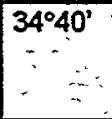 & & & & $\begin{array}{c}\square \\
\text { BER }\end{array}$ & & & & & & $34^{\circ} 40^{\prime}$ \\
\hline $\begin{array}{c}34^{\circ} 30^{\prime} \\
0\end{array}$ & & & & $\begin{array}{l}\Phi \Phi \\
\oplus \oplus\end{array}$ & $\begin{array}{l}.00 \\
. .00\end{array}$ & & & & & $34^{\circ} 30^{\prime}$ \\
\hline $\begin{array}{c}34^{\circ} 20^{\prime} \\
\therefore\end{array}$ & & & & & & & & & & $34^{\circ} 20^{\prime}$ \\
\hline $34^{\circ} 10^{\prime}$ & & & & & & & & & & $34^{\circ} 10^{\prime}$ \\
\hline $34^{\circ} 00^{\prime}$ & & & & Soc & & & & & & $\begin{array}{c}34^{\circ} 00^{\prime} \\
\vdots \ldots\end{array}$ \\
\hline $\begin{array}{l}\text { LATI } \\
\text { LONG }\end{array}$ & \begin{tabular}{c}
$107^{\circ} 20^{\circ}$ \\
$\cdots$ \\
\hdashline
\end{tabular} & $107^{\circ} 10^{\prime}$ & $107^{\circ} 00^{\prime}$ & $106^{\circ} 50^{\circ}$ & $106^{\circ} 40^{\circ}$ & $106^{\circ} 30^{\prime}$ & $106^{\circ} 20^{\prime}$ & $106^{\circ} 10^{\prime \prime}$ & $106^{\circ} 00^{\prime}$ & \begin{tabular}{|l} 
LATI \\
LONG
\end{tabular} \\
\hline 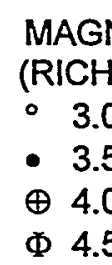 & $\begin{array}{l}\text { ITUDE } \\
\text { TER) } \\
-3.4 \\
-3.9 \\
-4.4 \\
-4.9\end{array}$ & & & & $\begin{array}{l}\text { CITY/TC } \\
\text { ABQ All } \\
\text { BER Be } \\
\text { EST Es } \\
\text { LAG La }\end{array}$ & $\begin{array}{l}\text { WN } \\
\text { uquerq } \\
\text { nardo } \\
\text { ancia } \\
\text { juna (P }\end{array}$ & $\begin{array}{l}\text { SOC So } \\
\text { SOblo) }\end{array}$ & $\begin{array}{l}\text { Santa F } \\
\text { corro }\end{array}$ & & \\
\hline
\end{tabular}

Figure 1-10. Map of Central Rio Grande Region of New Mexico, Showing Locations of Magnitude $\geq 3.0$ Earthquakes Detected by NM Institute of Mining and Technology Seismographs for the Period 1986 - 1994 (SNL 1995c). 


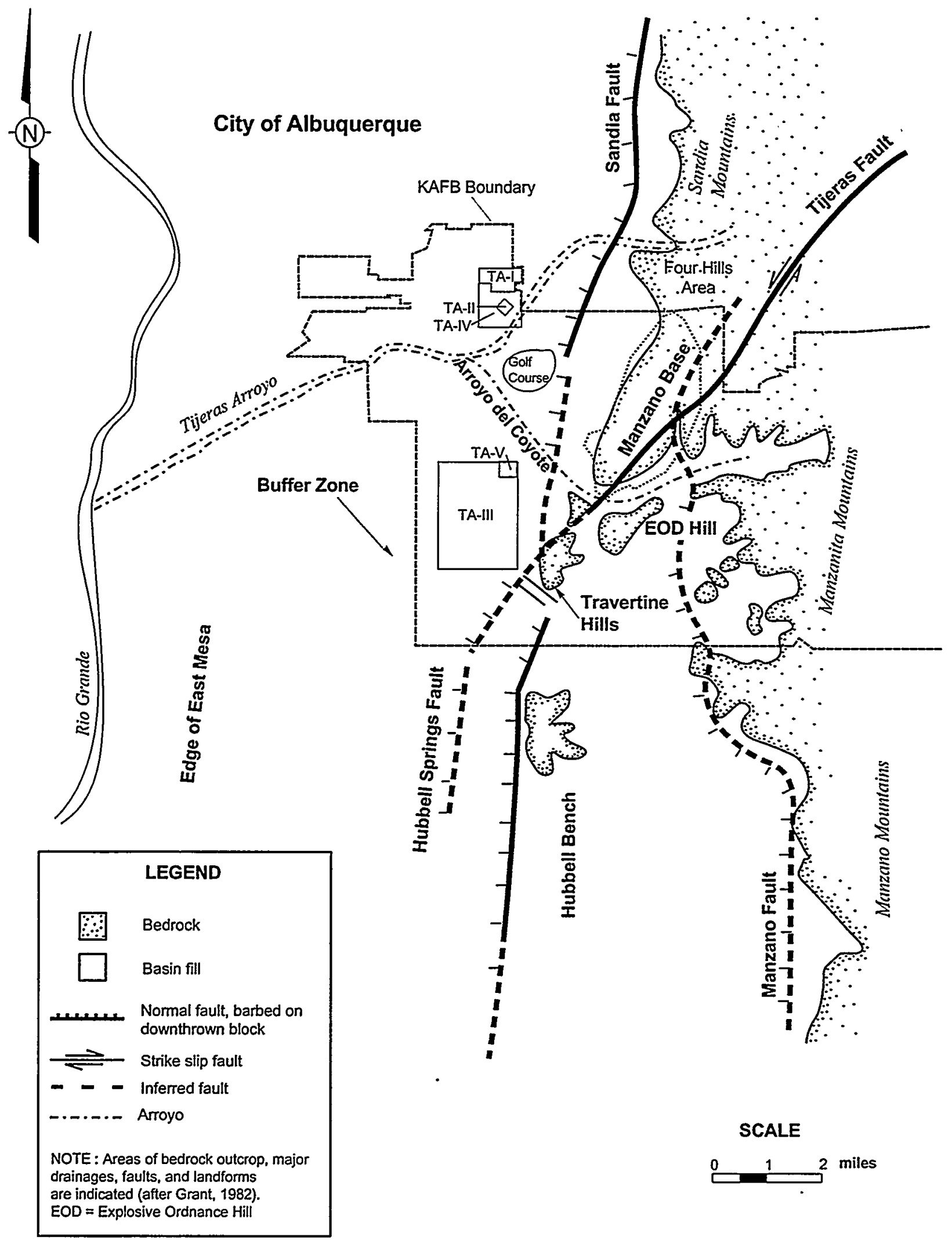

Figure 1-11. Fault Zones Near TA-V. 


\subsubsection{Flooding}

A thorough review of the existing literature (Pickard 1999, App. E) concluded that flooding at the site is extremely unlikely and, on the basis of historical evidence, is not apt to result from natural phenomena. TA-V is located on a mesa that slopes gently from the mountains westward to the river valley. The altitude of the site is $1657 \mathrm{~m}(5436 \mathrm{ft})$. The river valley is about $14 \mathrm{~km}(8.7 \mathrm{mi})$ west of the site at an altitude of $1500 \mathrm{~m}$ $(4920 \mathrm{ft})$. Because of the difference in elevation of $157 \mathrm{~m}(515 \mathrm{ft})$ and the distance from the river, flooding from the river does not present a threat to the AHCF.

As discussed in Section 1.4.2.1, precipitation that falls to the east and north of TA-V is carried by natural and artificial flow paths into two primary surface channels: the Tijeras Arroyo and the smaller Arroyo del Coyote. Floods in these arroyos are characterized by high peak flows, small volumes, and short durations. Because TA-V facilities are higher than these surface channels, and because they have been built outside the 500-year and 100 -year floodplains of the arroyos, the facilities are not threatened by flooding from these sources (SNL 1993).

No manmade structures in TA-V/TA-III store sufficient quantities of water to flood the site and cause structural failure.

\subsection{External Manmade Threats}

Potential manmade threats include aircraft crashes, chemical/toxic gas releases, fires, industrial or military facility accidents, loss of electrical power, soil erosion, criticality events, explosions, missiles, structural interactions, and transportation accidents. The potential effects of these and other external events on the AHCF are discussed in Appendix 3-D.

\section{$1.7 \quad$ NEARBY FACILITIES}

This section identifies both nearby facilities that could be affected by accidents within TA-V and hazardous operations or facilities on site or off site that could adversely affect operations at the AHCF.

TA-V installations that could affect or be affected by the AHCF include the ACRR, GIF, $\mathrm{HCF}$, Radiation Metrology Laboratory (RML), and the Sandia Pulse Reactor III (SPR III). The ACRR is designed to serve as the production facility for the domestic source of the medical isotope molybdenum-99. When operable, the GIF (currently under construction) is planned to provide three cobalt cells for total dose irradiation environments. SPR III provides intense neutron bursts for effects testing of materials and electronics. The RML provides radiation measurement services to Sandia's reactors, isotopic sources, and accelerator facilities. The HCF provides full capability to handle and analyze radioactive material. 
KAFB includes all of the SNL TAs, USAF and other military installations, and several civilian organizations (see also Section 1.3.2.2). Adjacent to and physically combined with the USAF installations is the Albuquerque International Airport, a large joint military/commercial transportation complex. No other commercial, industrial, or transportation facilities are within $6 \mathrm{~km}(4 \mathrm{mi})$ of the AHCF. Landing and takeoff patterns for the various runways at the airport facilities do not affect operations. The runway of most concern relative to operations is the east-west runway. Aircraft using the east end of this runway for landing or take off could possibly fly over the AHCF if approaching or leaving the airport in a southeasterly direction; however, any aircraft that fly over the area during takeoff are already fully airborne.

Military and SNL test ranges are all $1 \mathrm{~km}(0.63 \mathrm{mi})$ or more from TA-V; any accidents at these sites would not directly affect AHCF operations.

Several KAFB recreational facilities, for example, a golf course and stables, are located within $3000 \mathrm{~m}$ of the AHCF. Road access to these facilities is controlled in the event of an accident.

Accidents involving the transport of hazardous materials on routes near TA-V would not affect access to TA-V, since the area surrounding TA-V is crossed by numerous improved dirt roads. If an accident were to occur on the main route, emergency vehicles could still gain access to the area using one of the improved dirt roads.

A comprehensive group of probable accident types has been reviewed, and appropriate procedures have been incorporated into the SNL/NM Emergency Plan (SNL 1999a).

\subsection{VALIDITY OF EXISTING ENVIRONMENTAL ANALYSES}

No significant discrepancies exist between the effects of site characteristics identified in this study and those identified in recent studies of the site.

The hydrology of the site has changed significantly from the conditions reported in earlier environmental reports for this area (Bjorklund and Maxwell 1961). Changes in groundwater flow direction, depth to groundwater, and so forth are related to the increased withdrawal of groundwater from pumping wells in the Albuquerque and KAFB areas; however, they will not affect the design basis or modifications of the AHCF.

\subsection{REFERENCES}

(Borklund and Maxwell 1961) Borklund, L. J., and B. W. Maxwell, Availability of Groundwater in the Albuquerque Area, Bernalillo and Sandoval Counties, New Mexico, New Mexico State Engineer Technical Report 21, Santa Fe, NM, 1961.

(Chanin and Young 1997) Chanin, D. I., and M. L. Young, Code Manual for MACCS2: Volume 1, User's Guide, SAND97-0594 v. 1, 
-Sandia National Laboratories, Albuquerque, NM, March 1997.

(DOC 1990)

U.S. Department of Commerce, Bureau of the Census, 1990 Census of Population: General Population Characteristics, New Mexico, 1990 CP-1-33, Washington, DC, 1990.

(DOE 1999)

U.S. Department of Energy, Draft Site-Wide Enviranmental Impact Statement for Sandia National Laboratories/New Mexico, DOE/EIS-0281, U.S. Department of Energy, Albuquerque, NM, April 1999.

(DOE 1996)

U.S. Department of Energy, DOE Order 420.1, Chg. 2, "Facility Safety," U.S. Department of Energy, Washington, DC, October 24, 1996.

(DOE 1994a)

U.S. Department of Energy, DOE Order 5480.23, Chg. 1, "Nuclear Safety Analysis Reports," U.S. Department of Energy, Washington, DC, March 10, 1994.

(DOE 1994b)

(Doty et al. 1976)

U.S. Department of Energy, DOE Standard 3009-94, "Preparation Guide for U.S. Department of Energy Nonreactor Nuclear Facility Safety Analysis Reports," U.S. Department of Energy, Washington, DC, July 1994.

Doty, S. R., et al., "A Climatological Analysis of Pasquill Stability Categories Based on STAR Summaries," National Climatic Center, Asheville, NC, 1976.

(EPA 1995)

U.S. Environmental Protection Agency, CAP88, Clean Air Act Assessment Package, Radiation Shielding Center, CCC-542, U.S. Environmental Protection Agency, Oak Ridge, TN.

(Grant 1982)

(Homann 1994)

(ICBO 1994)

Grant, P.R., Jr., "Geothermal in the Albuquerque Area, New Mexico," in Guidebook New Mexico Geological Society, Volume 83, pp. 325-331, New Mexico Geological Society, 1982.

Homann, S.G., HOTSPOT Health Physics Codes for the $P C$, Lawrence Livermore National Laboratory, University of California, Livermore, CA, 1994.

International Conference of Building Officials, Uniform Building Code, Volume 2, Structural Engineering Design Provisions, Whittier, CA, May 1, 1994. 
(Lozinsky and Teford 1991)

(Merrick 1998)

(Olson et al. 1979)

(Pickard 1999)

(Sanford et al. 1972)

(SNL 1999a)

(SNL 1999b)

(SNL 1998)

(SNL 1997a)

(SNL 1999c)
Lozinsky, R. P., and L. Teford, Geology and Paleontology of the Santa Fe Group, Southwest Albuquerque Basin, Valencia County, New Mexico, New Mexico Bureau of Mines and Mineral Resources, Institute of Mining and Technology, Socorro, NM, 1991.

Merrick \& Company, Advanced Structural Investigation for the Auxiliary Hot Cell Facility Modifications at Sandia National Laboratory Building 6597, Merrick \& Company, Albuquerque, NM, 1998.

Olson, C. A., M. H. Hall, and H. J. Plagge, "Wind Data for the Albuquerque Area," SC-M-70-144, Sandia National Laboratories, Albuquerque, NM, May 1979.

Pickard, P. S., "Analysis of Criticality Probability for the SPR in Its Storage Pit," Proposed change to SPR Technical Specifications, transmitted to DOE Kirtland Area Office April 30, 1999, Sandia National Laboratories, Albuquerque, NM, 3/99.

Sanford, A. R., et al., Seismicity of the Rio Grande Rift in New Mexico, Circular 120, New Mexico State Bureau of Mines and Mineral Resources, Socorro, NM, 1972.

Sandia National Laboratories, "SNL/NM Emergency Plan," PN471011, Sandia National Laboratories, Albuquerque, NM, March 1999.

Sandia National Laboratories, Sandia National Laboratories/New Mexico Environmental Information Document, SAND99-2022/1 and /2, Sandia National Laboratories, Albuquerque, NM, 1999.

Sandia National Laboratories, 1997 Annual Site Environmental Report,.SAND98-1833, Sandia National Laboratories, Albuquerque, NM, August 1998.

Sandia National Laboratories, "Groundwater Monitoring Report." Sandia National Laboratories, Albuquerque, NM, March 1997.

Sandia National Laboratories, Sandia National Laboratories/New Mexico Geographic Data Atlas, SAND99-1775, Sandia National Laboratories, Albuquerque, NM, 1999. 
(SNL 1995a)

(SNL 1995b)

(SNL 1995c)

(SNL 1993)

(Sullivan 1993)

(Thom 1963)

(Turner 1969)

(Thorne et al. 1993)

(USDA 1977)
Sandia National Laboratories, "Resource Conservation and Recovery Act, Hazardous Waste Part B Permit Application, Mixed Waste Management Facilities," Sandia National Laboratories, Albuquerque, NM, January 1995.

Sandia National Laboratories, "Sandia National Laboratories, New Mexico Environmental Baseline Update-Revision 1.0," Sandia National Laboratories, Albuquerque, NM, March 1995.

Sandia National Laboratories, "Environmental Monitoring Plan," PLA 95-37, Air Quality Department, Sandia National Laboratories, Albuquerque, NM, July 31, 1995.

Sandia National Laboratories, Sandia National Laboratories Site-Wide Hydrogeologic Characterization Project Calendar Year 1992 Annual Report, SAND930681, Sandia National Laboratories, Albuquerque, NM, October 1993.

Sullivan, T. J., et al., "Atmospheric Release Advisory Capability: Real-time Modeling of Airborne Hazardous Materials," Bulletin of the American Meterorological Society, Volume 74, PG Stability Classes, 1993.

Thom, H. C. S., "Tornado Probabilities," Monthly Weather Review, October-December 1963.

Turner, D. B., Workbook of Atmospheric Dispersion Estimates, U.S. Department of Health, Education and Welfare, National Pollution Control Administration, Cincinnati, OH, 1969.

Thorne, C. R., P. McAda, and J. M. Kernodle, Geohydrologic Framework: Hydrologic Conditions in the Albuquerque Basin, Central New Mexico, Water Resources Investigation Report 93-4149, U.S. Geological Survey, Albuquerque, NM, 1993.

U.S. Department of Agriculture, Soil Survey of Bernalillo County and Parts of Sandoval and Valencia Counties, New Mexico, Soil Conservation Service, U.S. Department of the Interior, Bureau of Indian Affairs and Bureau of Land Management, 1977. 


\section{ChAPTER 2}

\section{FACILITIES DESCRIPTION}

\section{$2.1 \quad$ INTRODUCTION}

Chapter 2 provides information that will satisfy the requirements of DOE 5480.23 , paragraph(s) 8.b.(3)(d). ${ }^{1}$ (Topic 4, parts $\underline{b}$ and $\underline{\mathrm{c}}$ of the attachment to the order, are covered in Chapter 4.) This chapter also includes information that will partially satisfy the requirements of DOE 5480.23, paragraph(s) 8.b.(3)(b), (f), and (u). ${ }^{2}$

The chapter describes the AHCF structure and design basis, processes, confinement systems, safety support systems, and auxiliary systems. Administrative controls that support and enhance safe operations will be discussed in detail in the SAR.

\subsection{REQUIREMENTS}

This section identifies the design codes, standards, regulations, and DOE orders that establish the safety basis for the facility.

\subsubsection{DOE Orders and Standards, Laws, and Regulations}

The DOE orders and standards that establish the safety basis of the AHCF and the sections of the Code of Federal Regulations (CFR) that these orders are based on are presented below:

- 10 CFR 835, "Occupational Radiation Protection" - This code establishes radiation standards, limits, and program requirements for protecting occupationally exposed individuals from ionizing radiation resulting from the conduct of DOE activities (CFR 1998a).

- 29 CFR 1910, "Occupational Safety and Health Standards" - This code establishes standards for means of egress, hazardous materials, general environmental control, fire protection, occupational and environmental control, materials handling and storage, design safety, electrical systems, and the like (CFR 1998b).

- 29 CFR 1960, "Basic Program Elements for Federal Employee Occupational Safety and Health Programs and Related Matters" - This code specifies procedures for the evaluation of occupational safety and health programs, ensures compliance with Occupational Safety and Health Administration (OSHA)

' As amplified in Attachment 1, paragraph(s) 4.f.(3)(d)4a, of the Order (Topic 4).

${ }^{2}$ As discussed in the introduction to DOE-Standard (STD)-3009-94 (DOE 1994a). 
standards, and establishes mechanisms for inspection and abatement of unsafe conditions (CFR 1998c).

- DOE Order 420.1, Chg. 2, "Facility Safety" - This order establishes requirements for facility safety, including fire protection, nuclear criticality safety, and natural phenomena hazards mitigation (DOE 1996b).

- DOE Order 440.1A, "Worker Protection Management for DOE Federal and Contractor Employees" - This order ensures that worker protection policies and requirements are effectively implemented (DOE 1998).

- DOE Order 5480.23, Chg. 1, "Nuclear Safety Analysis Reports" - This order specifies that the facility and the principal equipment and processes must be described and evaluated (DOE 1994b).

- DOE Standard-1020-94, "Natural Phenomena Hazards Design and Evaluation Criteria, Chg. 1" - This standard governs seismic design (DOE 1996a).

- Executive Order 12196, "Occupational Safety and Health Programs for Federal Employees" - This executive order mandates that heads of agencies and the Secretary of Labor assure prompt abatement of unsafe or unhealthy working conditions by assuring, among other provisions, that periodic unannounced inspections are performed and that workers receive safety and health training (FR 1980).

- DOE Standard 3009-94, "Preparation Guide for U.S. Department of Energy Nonreactor Nuclear Facility Safety Analysis Reports" - This standard describes a preparation method for Safety Analysis Reports (SARs) that satisfies the requirements of DOE Order 5480.23 and is acceptable to the DOE (DOE 1994c).

\subsubsection{Industry Codes and Standards}

The AHCF will also meet all applicable requirements of industry codes and standards listed in DOE Orders 420.1, Chg. 2, and 440.1A, which include, but are not limited to, those listed below:

- “1997 Uniform Building Code” (ICBO 1997);

- "Life Safety 101," Industrial Special Use Occupancy (NFPA 1997);

- 'Nuclear Criticality Safety in Operations with Fissionable Materials Outside Reactors," ANS-8.1.R1988 (ANSI/ANS 1988); 
- “National Electrical Code," NFPA 70 (NFPA 1999);

- “National Electrical Safety Code," ANSI C2-1997 (ANSI 1997); and

- "Threshold Limit Values for Chemical Substances and Physical Agents and Biological Exposure Indices" (ACGIH 1998).

Applicable codes and standards not mentioned above will be cited throughout the PSAR.

\subsection{FACILITY OVERVIEW}

This section gives a brief overview of the current and historical uses of Building 6597 High Bay and the projected uses, configuration, and basic processes that will be performed in the AHCF. When completed, the AHCF will encompass the entire High Bay.

\subsubsection{Historical and Current Use of Building 6597 High Bay}

For more than a decade the Building 6597 High Bay has been the experimental assembly area for nuclear materials destined for TA-V nuclear reactors. In 1996 the Temporary Hot Cell was constructed in the High Bay to repackage fuel elements used in the New Production Reactor (NPR) Transient Fuel Testing Program (DOE 1995). These fuel elements were shipped back to the Savannah River Site (SRS).

Now that the fuel elements have been returned to SRS, the Temporary Hot Cell is being modified to become the AHCF. The AHCF will perform some of the functions lost when the primary hot cell in TA-V was turned over to the molydbenum-99 production program. Because of the possibility of cross-contamination, radioactive materials and mixed wastes will not be characterized and sorted in the same hot cell that is used for the production of medical isotopes.

\subsubsection{Projected Use of Facility}

The AHCF will be used primarily to characterize and repackage legacy materials that have been accumulating at SNL/NM for the past thirty years from DOE defense programs and from U.S. Department of Defense (DOD), U.S. Nuclear Regulatory Commission (NRC), and other related activities. In addition, the AHCF may be used for radioactive and mixed waste whose characteristics make that waste unsuitable for sorting at the RMWMF. During characterization, the AHCF will also provide any necessary short-term storage for materials and wastes.

The AHCF and the RMWMF together will provide the necessary capability to handle known legacy waste and material in the current inventory at SNL/NM. The RMWMF is not a Hazard Category 3 facility, and it cannot at this time handle special nuclear material (SNM). The RMWMF has both size and weight limitations and cannot at this time accept 
remote-handled packages. The AHCF is being constructed to fill the need at SNL/NM for a Category 3 nuclear facility. The AHCF will be able to accept and handle a wider range of weights, sizes, and radioactive inventories and dose levels than the RMWMF.

\subsubsection{Basic Configuration of Building 6597}

Building 6597 is divided into three sections: the High Bay, built in 1970; the Mid Bay; and the Low Bay (Figure 2-1). The High Bay is $30.5 \mathrm{~m} \mathrm{(100} \mathrm{ft)} \mathrm{north} \mathrm{to} \mathrm{south,} 23.8 \mathrm{~m}$

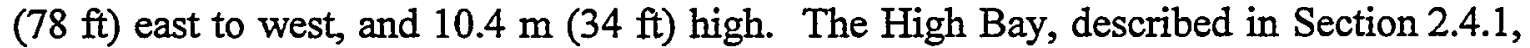
shares a common wall (south wall) with the Mid Bay. The Mid Bay, built in 1974, is approximately $18 \mathrm{~m}(60 \mathrm{ft}$ ) long (from north to south) and $16.5 \mathrm{~m}$ (54 ft) wide (from east to west). At present the Mid Bay is used for storage. The Mid Bay, in turn, shares a common wall with the Low Bay, which houses an instrument repair and calibration laboratory. The Low Bay is approximately $9 \mathrm{~m}(30 \mathrm{ft})$ long, $16.5 \mathrm{~m}(54 \mathrm{ft})$ wide, and 5.5 $\mathrm{m}(18 \mathrm{ft})$ high. It was built in 1978. In terms of square feet of usable space, the area of the High Bay is $725 \mathrm{~m}^{2}\left(7800 \mathrm{ft}^{2}\right)$, which includes the mezzanine area; the Mid Bay, 301 $\mathrm{m}^{2}\left(3240 \mathrm{ft}^{2}\right)$; and the Low Bay, $151 \mathrm{~m}^{2}\left(1620 \mathrm{ft}^{2}\right)$. Thus, the building has a total area of $1176 \mathrm{~m}^{2}\left(12,660 \mathrm{ft}^{2}\right)$. Occupancy for the High Bay is rated at H-7. The Mid Bay is rated S-2 (storage) and the Low Bay is rated B (general office/lab).

\subsubsection{Process Overview}

In the strict sense of the word, no routine process (production or experimental) activities will be conducted at the AHCF. Instead, each package will be characterized and handled using techniques that are determined to be individually appropriate. Therefore, the term process will be used throughout this PSAR in a more general sense - to mean a series of steps or procedures. The processes that will occur at the AHCF are the characterization, and in some cases sorting, of materials and wastes and the repackaging of these materials and wastes based on similarity and compatibility.

Characterization will determine which materials are suitable for reapplication to DOE and other federal agencies, and which materials, if any, have no economic value and may be disposed of as waste at DOE-designated facilities. Characterization may include some or all of the following activities.

Drums or packages containing radioactive materials initially may be $\mathrm{x}$-radiographed in Building 6635 in TA-III to determine the approximate position and type of contents. Additionally, the contents may be gamma scanned to identify the radioactive isotopes present. The storage containers may then be unpacked, either behind the shield wall, in the fume hood, or in the hot cell, depending on the nature of the contents. The unpacked contents will be inspected, videotaped, and finally repackaged and resealed in containers, as required.

The process for radioactive and mixed waste will be similar, except that once unpacked, transuranic (TRU) and low-level waste, where possible, will be separated from hazardous 


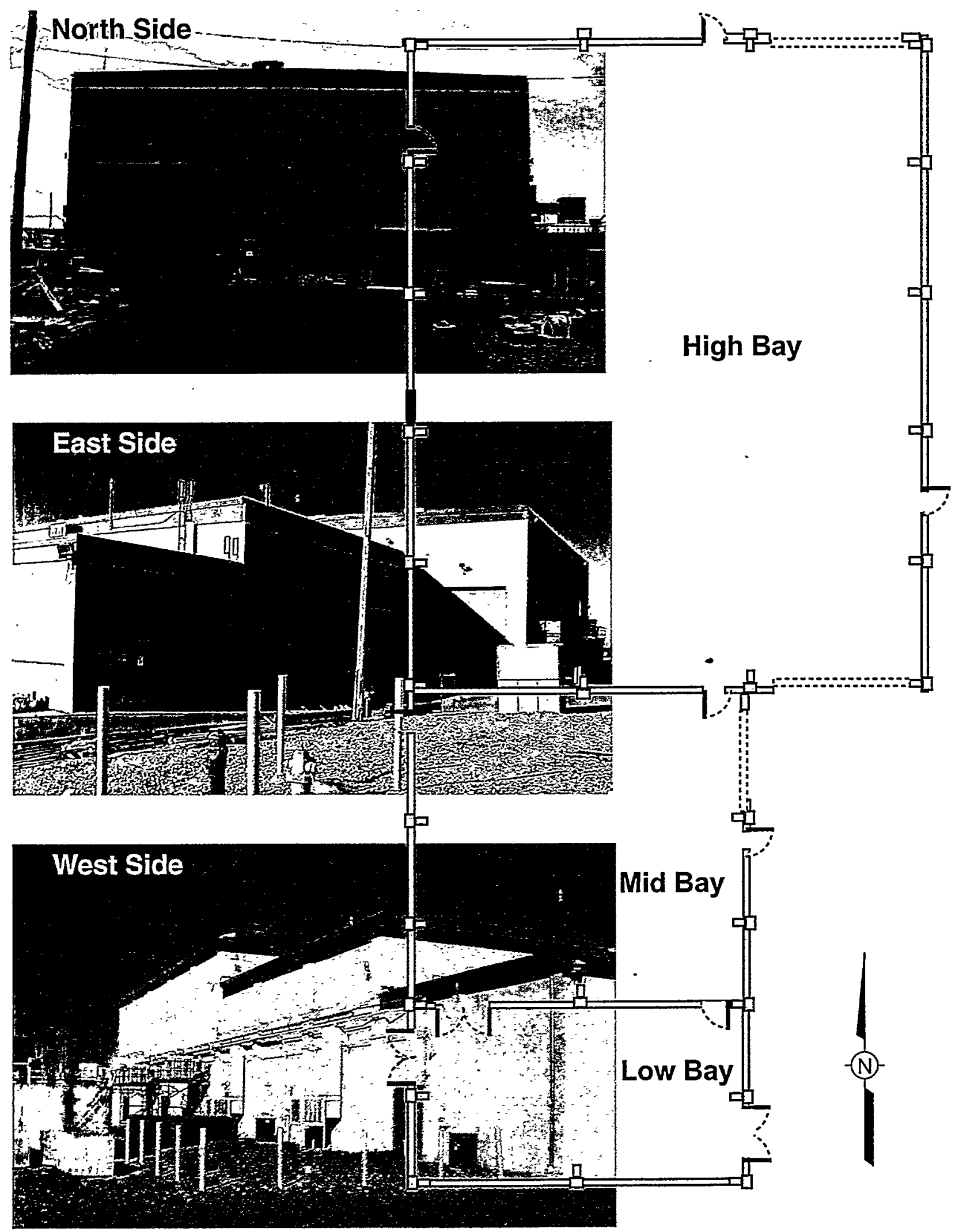

Figure 2-1. Basic Configuration of Building 6597 . 
waste and each will be repackaged in separate containers. According to type, these wastes would be sent to an appropriate treatment, storage, or disposal (TSD) facility.

\subsection{FACILITY STRUCTURE}

This section provides an overview of the AHCF and the structures and equipment within the building related to characterization, sorting, and repackaging of materials and wastes. The basic floor plan, equipment layout, construction materials, and dimensions are presented below.

A number of important modifications will be made to the existing Temporary Hot Cell to create the AHCF. The following major features will be added:

- A permanent shield wall will extend northward from the west wall of the hot cell.

- Eight floor silos will be constructed-two inside the hot cell, and six behind the permanent shield wall. These silos will facilitate package handling and will be used for shielding during operations and for storage. Each one of the six silos behind the permanent shield wall will be an independent Category 3 nuclear facility.

- The hot cell roof will be replaced to allow the placement of two roof portals over the two silos in the hot cell.

- A ventilation system will be upgraded to a two-stage high efficiency particulate air (HEPA) filter serving a fume hood and temporary room as well as the hot cell.

- The existing hot-cell jib crane will be upgraded.

- Video cameras will record operations and facilitate remote-handled operations.

These features enhance SNL/NM's ability to safely characterize, handle, treat, and package its radioactive legacy inventory.

\subsubsection{Auxiliary Hot Cell Facility}

The AHCF consists of the High Bay and includes the hot cell, fume hood, shield walls, temporary room, support systems and equipment, and storage areas. The south portion of the High Bay is currently used for shared storage with other SNL programs. There are no safety-class structures, systems, or components (SSCs) associated with Building 6597 or the AHCF. The five safety-significant components of the AHCF are the hot cell walls and roof; the permanent shield wall; the shield plugs for silos behind the permanent shield wall; the AHCF ventilation system (Zone 1); and the HEPA filters. The overall Building 6597 ventilation system (Zone 2) has no safety-significant components. (Ventilation zones are discussed in detail in Section 2.6.4.) 


\subsubsection{Basic Floor Plan and Layout of Equipment and Structures}

The basic floor plan and layout of equipment and structures within the AHCF are shown in Figure 2-2. Additional information is provided below.

- Hot Cell: The 5.1-m (16-ft 8 in.)-square hot cell is located $2.7 \mathrm{~m}(9 \mathrm{ft})$ from the east wall of the High Bay and $9.1 \mathrm{~m}(30 \mathrm{ft})$ from the north rollup door. The hot cell is described in detail in Section 2.4.2.1.

- Cranes: Two double-girder bridge cranes, each with a capacity of $5440 \mathrm{~kg}$ (6 tons), span the 24-m (78-ft) width of the High Bay. A chain hoist and jib crane will also be used at the AHCF. Additional information about the cranes is provided in Section 2.5.2.

- Cameras: Two remote-monitored cameras and two motion detectors will be installed outside to monitor the exterior of the building during periods when high dose rates are expected outside. Three cameras will be mounted inside the building in the processing area outside the hot cell, and three cameras will be mounted inside the hot cell. For more information on these cameras, see Section 2.5.2.5.

- Silos: Four 25.4-cm (10-in.)-inside diameter (ID), 4.6-m (15-ft)-deep floor silos and two 76.2-cm (30-in.)-ID, 4.6-m (15-ft)-deep floor silos will be located north of the hot cell behind the permanent shield wall (see Figure 2-2). One 76.2-cm $(30-i n$.) silo and one $25.4-\mathrm{cm}$ (10-in.) silo will be aligned on center with the viewing window in the permanent shield wall. These outside silos will have removable locking-type shield plugs. A prototypical design for the shield plugs is briefly described in Section 2.4.2.5. The tops of the outside silos will be raised slightly above the general floor level to reduce the possibility for the entry of water into the silo. A 38-cm (15-in.)-thick pad of $4.7 \mathrm{~g} / \mathrm{cm}^{2}$ concrete will be incorporated into the floor in the area of the silos behind the permanent shield wall. This pad will provide additional shielding of radiation sources in the silos in order to reduce doses to levels that are as low as reasonably achievable (ALARA).

Two silos, each $25.4 \mathrm{~cm}$ (10 in.) ID and $4.6 \mathrm{~m}$ (15 ft) deep, will also be placed in the hot cell. Inside silos will have covers that are flush with the floor. All silos will have watertight, removable, stainless steel liners, and additional stationary steel enclosures.

- Fume Hood: The fume hood will be located north and east of the hot cell. It is a walk-in fume hood that will accommodate two 208-liter (55-gal) drums placed side by side. Additional details about the proposed construction and components of the fume hood are presented in Section 2.4.2.2. 


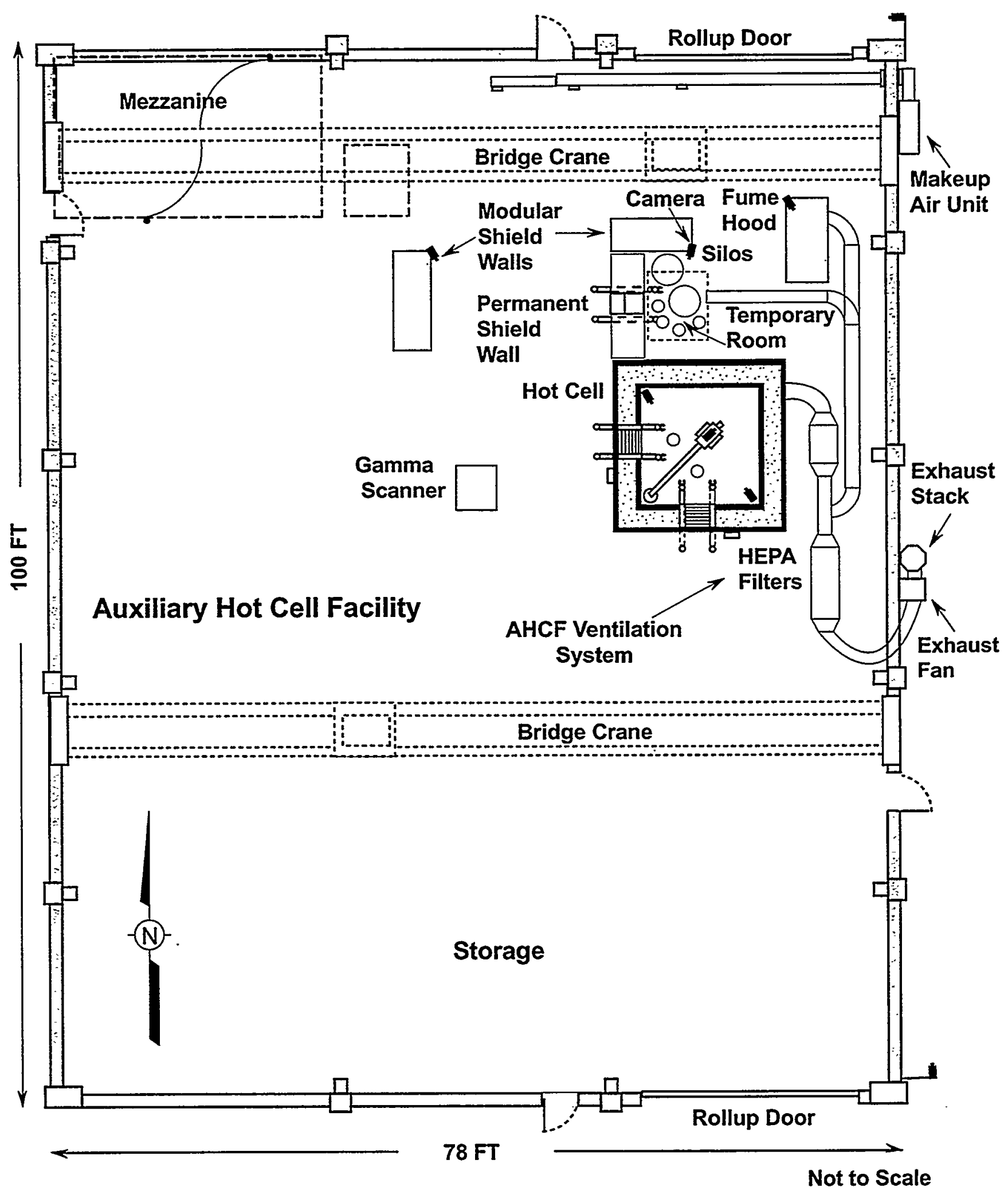

Figure 2-2. Auxiliary Hot Cell Facility. Locations of cameras and modular shield walls are illustrative and may change on a package-by-package basis. 
- Shield Walls: One permanent shield wall is planned for the AHCF. Modular shield walls and other shielding will be erected as needed to comply with SNL's RPPM (SNL 1999a) and ALARA principles. The permanent shield wall will be an extension of the west wall of the hot cell. Additional information about the shield walls is presented in Section 2.4.2.3.

- Ventilation Systems: The ventilation system for the fume hood, temporary room, and hot cell, described in Section 2.6.4, is a stand-alone system to be located east of the hot cell.

The Building 6597 ventilation system consists of side-wall mounted evaporativecooling units and manually operated roof-relief vents. This system may be modified if further analysis determines that the units fail to meet H-7 Uniform Building Code (UBC) facility requirements.

- Storage: The south side of the building is currently being used for temporary storage.

- Gamma Scanner: The gamma scanner will be located west of the hot cell, as shown in Figure 2-2.

\subsubsection{Building 6597 Structural and Mechanical Components}

The construction materials and controlling dimensions of Building 6597's structural and mechanical components are described in detail in the design criteria (SNL 1998b) and summarized as follows:

- Floor: The floor is a 20-cm (8-in.)-thick concrete (3000 psi) slab reinforced with \#4 reinforcing bars spaced every $30 \mathrm{~cm}$ (12 in.) on center in each direction. Steel grating or concrete covers cap the floor trenches that run throughout the building.

- Walls: Concrete masonry unit (CMU) walls are set between cast-in-place concrete columns. The columns, set every $6.1 \mathrm{~m}(20 \mathrm{ft})$ on center along the east and west walls, support the runways for the overhead bridge cranes. On the north and south sides, the concrete columns are $7.9 \mathrm{~m}(26 \mathrm{ft})$ on center. The north and south wall columns frame into intermediate- and roof-level beams. The $30-\mathrm{cm}$ (12-in.)-thick building walls are reinforced with \#6 rebar spaced every $1.8 \mathrm{~m}(6 \mathrm{ft})$ on center in each direction.

- Roof: The roof is constructed of a series of 46-cm (18-in.)-wide, 22-gauge metal roof decking panels supported by open-web steel joists placed $1.2 \mathrm{~m}(4 \mathrm{ft})$ on center. These joists span the $24-\mathrm{m}$ (78-ft) width of the building. Rigid insulation that is 5-cm (2-in.) thick sits on top of the metal deck. The exterior finish consists of a 4-ply built-up roofing system covered with gravel. The roof slopes $2-\mathrm{cm} / \mathrm{m}$ 
( $1 / 4 \mathrm{in} / \mathrm{ft}$ ) to the east and west from the center ridge. Metal scuppers and downspouts on the exterior of the building catch roof runoff. Splash blocks direct runoff from the downspouts away from the building. Lightning protection is currently in place on the roof of Building 6597; when the exhaust stack is extended, it will be the highest point on the building and will be equipped with a lightning rod.

- Doors: Two metal overhead coiling (rollup) doors, one each at the south and

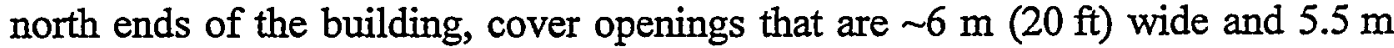
$(18 \mathrm{ft})$ high. The building's four 90-cm (36-in.) exit doors are constructed of hollow metal. These doors are set into the CMU walls in hollow metal frames. The doors will be equipped with closers and panic hardware. Where required, exit doors will have illuminated exit signs.

- Windows and Frames: The High Bay of Building 6597 has no windows or window frames.

Building 6597 is not seismically ratable and cannot be guaranteed to remain intact if subjected to a design-basis earthquake. Building 6597 structurally supports the bridge crane; administrative controls will prohibit parking the crane above the hot cell.

\subsubsection{AHCF Structural and Mechanical Components}

This section presents the AHCF components, construction materials, controlling dimensions, and dimensions significant to the hazard and accident analysis.

The hot-cell walls, permanent shield wall, and shield plugs are all designed to meet a criterion of $2.5 \mathrm{mrem} / \mathrm{hr}$ at the cold surface when a $6 \mathrm{kCi}$ source of mixed fission products, more than 120 days post-irradiation, is placed immediately adjacent to the hot surface. This dose rate at the cold surface would result in an annual dose of $5 \mathrm{rem}$ to a worker standing against the wall for 40 hours/week, 50 weeks/year. In fact, no AHCF worker will receive a 5 rem annual dose, for four reasons:

- Neither worker nor source is immediately adjacent to the wall more than

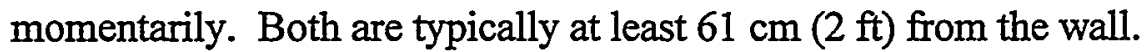

- Processing time for any given source is expected to be no more than a few days.

- The largest source in the current Sandia legacy inventory scheduled for handling in the AHCF is $500 \mathrm{Ci}$, one-twelfth of the design source, and very few of the packages in inventory contain sources as large as $500 \mathrm{Ci}$. 
- Strict administrative controls as prescribed by Sandia's implementation of 10 CFR 835 (CFR 1998a) in the Radiological Protection Procedures Manual (RPPM; Sandia 1999a) are in place.

\subsubsection{Hot Cell}

The existing hot cell was built in late 1996 to design criteria that included Seismic Zone 2b Performance Category 2 requirements and 94 UBC standards (SNL 1998a). The upgrades to the AHCF will allow the hot cell to meet $97 \mathrm{UBC}$, a code upgrade that influences the earthquake-design provisions and load factors discussed in Chapter 3. The design of hot cell mechanical and structural components meets all worker safety requirements, assuming the bounding limit of a $6.0 \mathrm{kCi}$ source of mixed fission products placed adjacent to the interior wall of the hot cell and a worker standing along the exterior wall. The radiation dose rate through the walls is designed to satisfy ALARA design goals stated in the Sandia RPPM (SNL 1999a), that is, to maintain exposure levels below an average of $0.5 \mathrm{mrem}$ per hour in areas of continuous occupational occupancy (i.e., radiation workers) and as far below this average as is reasonably achievable. Where occupancy differs from the above (i.e, non-radiation workers), exposure will be ALARA and will not exceed $20 \%$ of the applicable standards in the RPPM, Radiological Worker Requirements, Attachment 5-1.

Outside overall dimensions of the hot cell are $5.1 \mathrm{~m}$ (16 ft 8 in.) square and $4.9 \mathrm{~m} \mathrm{(16 \textrm {ft }}$ $2 \mathrm{in}$.) high (Figure 2-3). Inside working space dimensions are $3 \mathrm{~m}$ (10 ft) square with a clear inside height of $4.2 \mathrm{~m}$ (13 ft $10 \mathrm{in}$.). The height dimension includes a deduction for the raised concrete floor mat constructed in 1996. The hot cell interior space is functionally laid out into the receiving area, the area bounded by the reach of the manipulator arms, and the area bounded by the swing (arc) of the jib crane boom. Hot cell equipment is described in Section 2.5.2. Structural and mechanical components of the hot cell are described below.

- Foundation/Floor: A 46-cm (18-in.)-thick concrete foundation mat supports the hot cell. The floor inside the hot cell is raised $10 \mathrm{~cm}$ (4 in.) above the floor level of Building 6597 to prevent shine under the walls. In 1996, this foundation was locally thickened by an additional $30 \mathrm{~cm}(12 \mathrm{in}$.) at the foot of the interior jib crane located in the southwest corner of the hot cell.

- Wall Panels: The hot cell walls are constructed of inner and outer, precast, 20$\mathrm{cm}$ (8-in.) reinforced concrete panels. The inner and outer wall panels are separated by a $61-\mathrm{cm}$ (24-in.) space filled with common construction-grade sand. The panels have been welded together at embedded connection angles precast into the panels. Threaded rods maintain a given separation between inner and outer hot-cell walls. All wall seams are offset to prevent direct shine. 


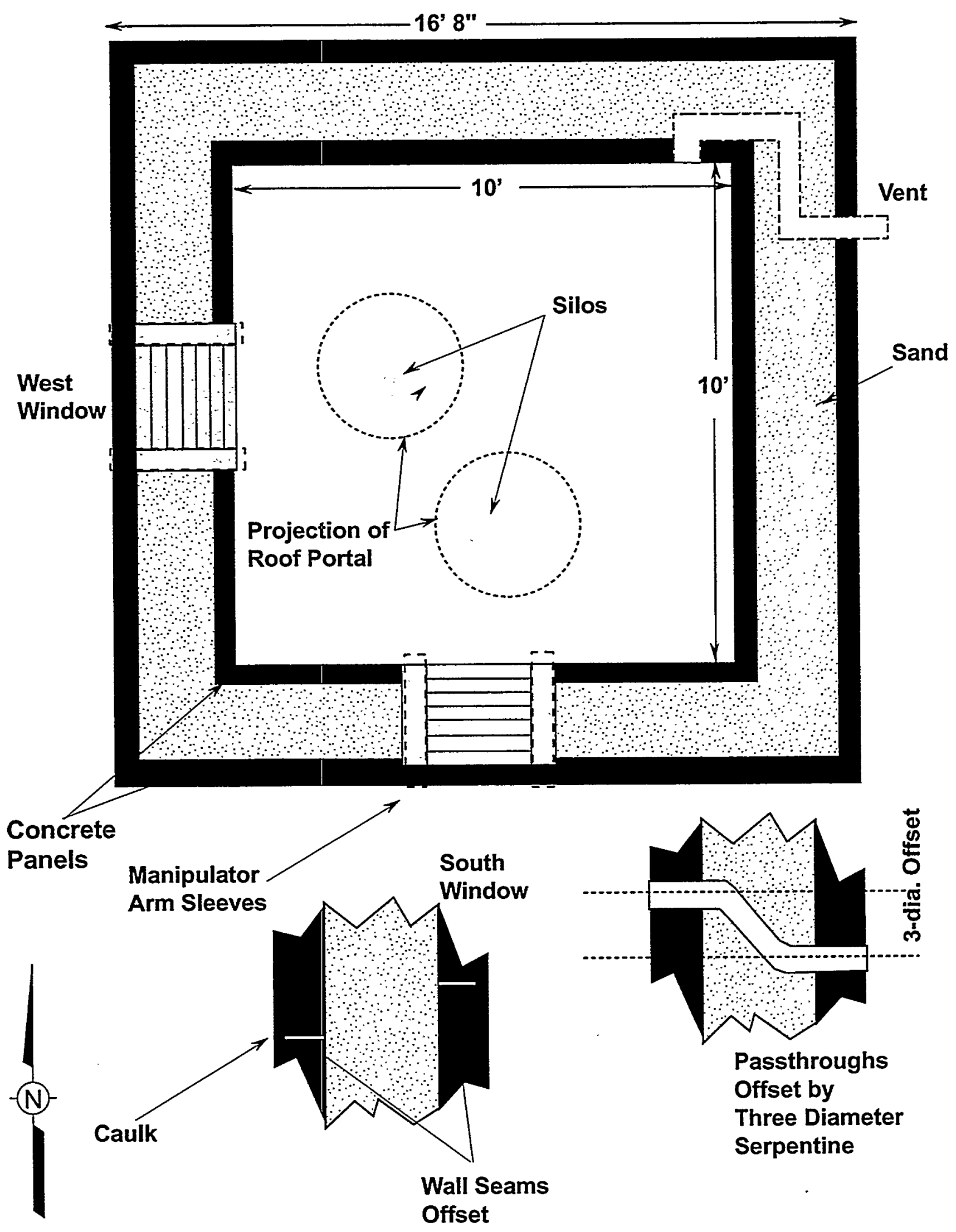

Figure 2-3. Hot Cell Structural and Mechanical Components (SNL 1996, 1997). 
- Windows: The windows are the Hanford Fuel and Materials Examination Facility (FMEF) Type "C" windows. The windows have a total attenuation of 259 density-cm (102 density-in.), dominated by two 18-cm (7-in.)-thick panes of $6.2 \mathrm{~g} / \mathrm{cc}$ leaded glass. By comparison, the wall attenuation is 216 density-cm ( 85 density-in.). As a result, the windows provide better shielding than the walls, which is confirmed by the dose rate calculation showing the window surface dose rate to be $0.13 \mathrm{mrem} / \mathrm{hr}$ when a full $6.0 \mathrm{kCi}$ source of mixed fission products is in the hot cell. Even if the oil were to leak from the windows, the attenuation would still be 236 density-cm ( 93 density-in.), which is greater than that of the walls.

- Manipulator Arm Sleeves: Manipulators will be used to handle packages inside the hot cell. The through-wall manipulator sleeves are constructed of $25-\mathrm{cm}(10-$ in.)-ID pipe $100 \mathrm{~cm}$ ( $40 \mathrm{in}$.) long. These sleeves have been installed $3 \mathrm{~m}(10 \mathrm{ft})$ above and horizontal to the floor. The manipulators contain internal shielding to minimize streaming; however, localized dose rates in the vicinity of the manipulator passthroughs are expected to be higher than those for the adjacent walls. The portion of the wall is approximately $3 \mathrm{~m}(10 \mathrm{ft})$ above floor level and thus is not normally occupied.

- Window Frames: The cold-wall side of the window frame has two 6.4-cm (2.5in.)-thick steel collars to prevent shine in the gaps between the window frame and concrete walls. The hot-wall side of the window frame has a $3.43-\mathrm{cm}(1.35-\mathrm{in}$.) step to accommodate the $3.18-\mathrm{cm}(1.25-\mathrm{in}$.) step in the frame.

- Passthroughs: All wall passthroughs, other than manipulator arms and windows, have at least a three-diameter serpentine offset to eliminate direct shine. The following is a list of passthroughs:

- 2.54-cm (1-in.)-diameter type $316 \mathrm{SS}$ for gas line penetration,

- Port for jib crane power,

- Port for jib crane controls,

- Port for power to lights,

- Ports for fire suppressant, and

- Port for vent duct.

- Roof: Because the area above the hot cell is not inhabited, the dose rate criterion for the roof is less stringent than that for the walls $(100 \mathrm{mrem} / \mathrm{hr}$ as compared to $2.5 \mathrm{mrem} / \mathrm{hr}$ ). In cross section, the current roof is constructed of two $20-\mathrm{cm}$ (8in.)-thick reinforced concrete panels with $30 \mathrm{~cm}$ (12 in.) of sand between them. Because two 90-cm (36-in.)-diameter roof openings will be required, the current roof will be replaced by two new sections, each consisting of two precast concrete roof panels (Figure 2-4). Each individual roof panel is designed to structurally support one 2300-kg (5000-lb)-point load. Although the roof is a composite structure comprising two concrete panels with a layer of sand between them, it has 


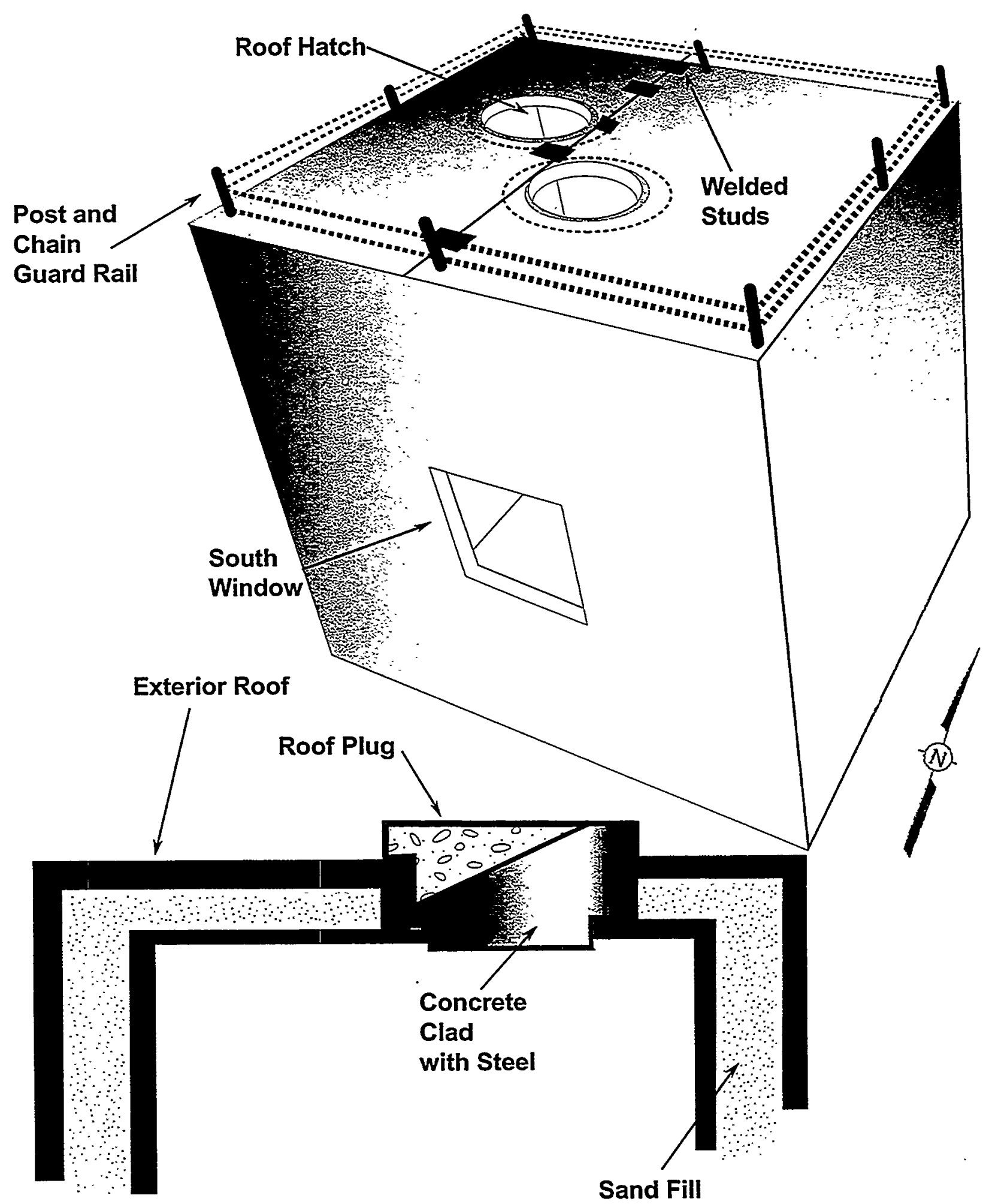

Figure 2-4. Hot Cell Roof. 
not been determined that the hot-cell roof will support two $2300-\mathrm{kg}$ (5000-1b) point loads simultaneously. The roof will be constructed in two sections, each supporting a roof port and roof plug. Therefore, an administrative control will ensure that when the roof plugs are removed, only one plug is placed on a given roof section at a time.

Calculated doses on the outside surface of the hot-cell roof depend on the height of the source above the floor. For a $6 \mathrm{kCi}$ source of mixed fission products, more than 120 days post-irradiation, located $3 \mathrm{ft}$ above the hot-cell floor, the dose on the outside surface of the roof is calculated to be $10 \mathrm{mrem} / \mathrm{hr}$; for a source $7 \mathrm{ft}$ above the floor, the dose is $20 \mathrm{mrem} / \mathrm{hr}$; and for a source 11 feet above the floor, the dose is $66 \mathrm{mrem} / \mathrm{hr}$ (Duong 1999).

- Roof Openings and Plugs: The two 91-cm (36- in.)-diameter roof openings will be positioned as close to the centerline of the windows as possible (Figure 2-4). The roof plugs and roof penetrations will be clad with steel to minimize damage during handling. Because roof access is controlled, design-criteria doses for the roof are $100 \mathrm{mrem} / \mathrm{hr}$ (SNL 1999a).

- Silos: Two storage silos ( $25.4 \mathrm{~cm}$ ID by $4.6 \mathrm{~m}$ deep [10 in. ID by $15 \mathrm{ft}$ deep]) will be centered on the hot-cell windows and located below the roof portals. Items lowered through the roof portals can be inserted into these silos. The silos will have a removable cover flush with the existing finished floor elevation. The silos will allow easier and safer staging and access to the top of tall packages. Sources located in the silos inside the hot cell are shielded by the soil surrounding them as well as by the hot-cell walls. No chord through the soil is shorter than the distance through the hot cell, and the attenuation of soil and concrete are similar. Therefore, sources located in the hot-cell silos will be shielded more than sources located in the hot cell itself.

\subsubsection{Fume Hood}

The fume hood will be used to characterize contact-handled wastes or materials that may produce hazardous fumes or to handle wastes or materials that have very small amounts of spreadable particulates. The expected exposure of personnel to radioactivity will not exceed RPPM guidelines.

The fume hood is a Kewaunee Hoodaire II \#SH-3446-S, 1.8-m (6-ft.)-wide, double-sash fume hood. The exhaust system, described in Section 2.6.4, will operate as needed for both the fume hood and the temporary room (described in Section 2.4.2.4). The fumehood exhaust system will operate at a rate between 1740 and 3360 actual cubic feet per minute (acfm) based on the following:

- Walk-in fume hood with one sash open: $1740 \mathrm{acfm}$; and 
- Walk-in fume hood with two sashes open: $3360 \mathrm{acfm}$.

The discharge ductwork of the existing building evaporative-cooling unit located adjacent to the fume hood will be modified to minimize unwanted air currents in the vicinity of the fume hood.

\subsubsection{Shield Walls}

The permanent shield wall, adjacent to the hot cell, is constructed of normal-density (144 $\left.\mathrm{lb} / \mathrm{ft}^{3}\right)$ concrete. This wall will be $0.9 \mathrm{~m}(3 \mathrm{ft})$ thick, $3.7 \mathrm{~m}(12 \mathrm{ft})$ high, and $3 \mathrm{~m}(10 \mathrm{ft})$ wide. It will have a shielded viewing window that is $76 \mathrm{~cm}(30 \mathrm{in}$.) wide and $61 \mathrm{~cm}(24$ in.) tall. Central Research Laboratory (CRL) Model F master-slave manipulators will be positioned above and on each side of the shielded viewing window to open containers.

Modular shield walls will be constructed of concrete modules, typically $61 \mathrm{~cm}(24 \mathrm{in}$.) thick by $90 \mathrm{~cm}$ ( $36 \mathrm{in}$.) tall by $1.8 \mathrm{~m}(6 \mathrm{ft})$ long, stacked to an appropriate height. Modular shield walls will serve as a shield for workers when packages are being lifted above the hot cell roof and into the hot cell.

Other temporary shielding, for instance, an awning above the permanent shield wall, will be erected and dismantled as consistent with the RPPM (SNL 1999a) and ALARA principles.

\subsubsection{Temporary Room}

From time to time, a temporary tent-like room will be field erected east of the permanent shield wall to accommodate large packages that present the possibility of spreadable contamination. If the package must be remotely handled, the temporary room will be built directly against the permanent shield wall to allow the use of the manipulators. Each time the temporary room is erected, package-specific considerations will determine details of the design; however, basic construction will likely consist of metal framing, clear or translucent plastic roof and walls, and plastic zippered doors. The temporary room will operate at a slight negative pressure. A flexible exhaust duct will connect the room to the AHCF Zone 1 ventilation system. A motorized control damper will isolate this exhaust stream from the other exhaust streams being serviced.

\subsubsection{Shield Plugs}

In the past, Sandia has fabricated shielded lids for storage holes (dense pack, monorail storage holes, ACRR floor holes) with steel shells filled with poured lead. The shield plugs are stepped to be larger in diameter than the storage holes by at least $10 \mathrm{~cm}$ ( 4 in.) on the diameter. The plugs attenuate the collimated radiation from a source located down the hole. Because the density and, hence, attenuation of the soil or concrete surrounding the top of the hole is much less than the lead, the source strength and location of sources in storage (distance from the top of the hole) must be administratively controlled so that 
the shortest chord through the soil adjacent to the shield plug is long enough to provide adequate attenuation. The depth of the storage silos will accommodate the shield plugs to leave the necessary free height for packages.

\subsection{PROCESS DESCRIPTION}

This section describes the individual processes within the AHCF. It discusses the types of hazardous material and wastes to be handled and describes process equipment and instrumentation and control systems. It also includes a basic process flow diagram.

\subsubsection{Types and Quantities of Materials and Radioactive and Mixed Waste}

Materials and wastes described in this section represent current inventories and may not necessarily be fully representative of quantities and types of future wastes and materials processed at the AHCF. However, all present and future waste inventories processed at the AHCF will be bounded by Category 2 thresholds in each segment described in Chapter 3.

\subsubsection{Materials}

Materials currently waiting to be characterized typically include the following:

- Hardware from reactor experiments;

- Unirradiated and irradiated fissile material in the form of pellets, foils, and intact fuel rods or fuel pins;

- Uranium and plutonium fines from reactor failure experiments;

- Irradiated TRU waste; and

- Neutron sources.

Most packages contain items with irradiated U-235 or Pu-239. Packages stored in the SPR Dense Pack, a storage yard of silos outside the SPR, contain decayed fission products from irradiated fuels in either open-pellet or granular form. The dominant radioisotopes remaining are Sr-90 and Cs-137 (which emit primarily beta and gamma rays). There are also actinides in some of the packages in the current SNL inventory (e.g., Pu-238, Pu-239, Pu-240, Pu-241, Pu-242, and Am-241 [Lipinski et al. 1999])

\subsubsection{Radioactive and Mixed Waste}

The radioactive components in SNL/NM's current radioactive and mixed-waste inventory are primarily isotopes of cesium, strontium, plutonium, americium, and uranium. (In addition to the actinides mentioned above, isotopes in the current inventory include, for example, Cs-134, Cs-137, Sr-90, Am-242m, Am-243, Cm-242, Cm-245, Np-237, Np-238, U-233, U-234, U-235, U-236, and U-238 [Lipinski et al. 1999]. Estimated 
quantities of isotopes of interest will be given in Chapter 7 of the SAR.) Proposed treatments for present and future inventories that come to the AHCF include neutralization, encapsulation, and stabilization. The present inventory of such items includes

- Experimental hardware, including metals regulated under the Resource Conservation and Recovery Act (RCRA);

- Miscellaneous material used in extraction experiments;

- Radioactive waste regulated by RCRA because of characteristics such as corrosivity or reactivity, e.g., sodium; and

- Radioactive waste contaminated with trace solvents.

\subsubsection{Process Equipment}

Equipment that will be used in the moving, unpacking, lifting, characterization, sorting, recording, and repackaging activities is described below. Safety of process equipment will be described in Section 2.5.6.4.

\subsubsection{Trucks and Forklifts}

The same trucks used to transport wastes and materials from generator storage locations throughout SNL/NM would be used to transport wastes or materials from storage locations to Building 6597. Forklifts may be used to move the waste inside the building or between nearby TA-V buildings and Building 6597.

\subsubsection{Building 6597 Bridge Cranes}

The bridge cranes will be used to lift items from the truck or forklift to the area behind the permanent shield wall, and, when appropriate, to and from the roof of the hot cell. Crane bridges travel north and south, and trolleys travel east and west. Each crane has a $5440-\mathrm{kg}$ (6-ton) capacity and a hook height of $8.2 \mathrm{~m}$ ( $26 \mathrm{ft} 8 \mathrm{in}$.). The hook height leaves enough space between the roof of the hot cell and the hook to accommodate most packages described above in Section 2.5.1. A chain hoist attached to the bridge crane will be used to lower packages into the hot cell. The use of the chain hoist reduces the potential for contamination of the bridge crane and makes it possible to provide a costeffective backup power supply.

Packages that exceed the weight limitations of the chain hoist or that are longer than about $2.4 \mathrm{~m}(8 \mathrm{ft})$ cannot be inserted directly into the hot cell using the chain hoist. The long packages cannot be lifted high enough to clear the roof using both the bridge crane and chain hoist. A package-specific plan will be developed for packages too long or too heavy to go into the hot cell with the normal bridge-crane and chain-hoist configuration (see Section 2.5.4). Some of the options include the following:

- Temporarily remove the chain hoist and use only the bridge crane; 
- Place the package in a silo behind the permanent shield wall for partial disassembly and subsequent placement in the hot cell; or

- Handle the package behind the permanent shield wall.

The chain hoist will be supported by a redundant power supply from standby generators. No redundant power supply is necessary for the bridge crane. In the event of a power outage, the bridge crane is inoperable and locks in place. If a power outage occurs while an exposed radiation source that presents an unacceptable hazard as defined by the RPPM is suspended from the bridge crane and chain hoist, the chain hoist, in combination with tethers if necessary, will be used to lower the package to a safe configuration until power returns.

\subsubsection{Hot Cell Jib Crane}

The hot cell jib crane will be used to move packages placed inside the hot cell. The jib crane is mounted to the floor of the structure (Figure 2-5). Controls for the jib crane are outside the hot cell at each of the two windows. All functions (raise/lower, trolley, and swing) are available at each control box. The jib crane has the following specifications:

- Jib crane capacity is presently $453.5 \mathrm{~kg}(1000 \mathrm{lb})$. This capacity will be increased to $907 \mathrm{~kg}(2000 \mathrm{lb})$.

- The maximum jib crane hook height is $2.9 \mathrm{~m}(9.7 \mathrm{ft})$.

- Jib crane boom length is the maximum length allowed by hot cell dimensions.

\subsubsection{Manipulators}

CRL Model F manipulators will be used to open packages, sort items, and repack packages. The through-wall manipulator sleeves are constructed of 25.4-cm (10-in.)-ID pipe $100 \mathrm{~cm}$ (40 in.) long, installed $3 \mathrm{~m}(10 \mathrm{ft})$ above and horizontal to the floor.

\subsubsection{Building and AHCF Cameras}

The cameras used for building and hot-cell monitoring are model CC4700-2 Pelco video cameras. Cameras used in the hot cell will be shielded to the extent possible. Three cameras are planned for the work area outside the hot cell. One will be mounted on the shield wall and a second at the fume hood. A final camera will be mounted on existing scaffolding attached to the mezzanine; this camera will view the ports on the roof of the hot cell during introduction and removal of items into the hot cell. Three cameras are planned for the interior of the hot cell: a jib crane camera and two wall-mounted 


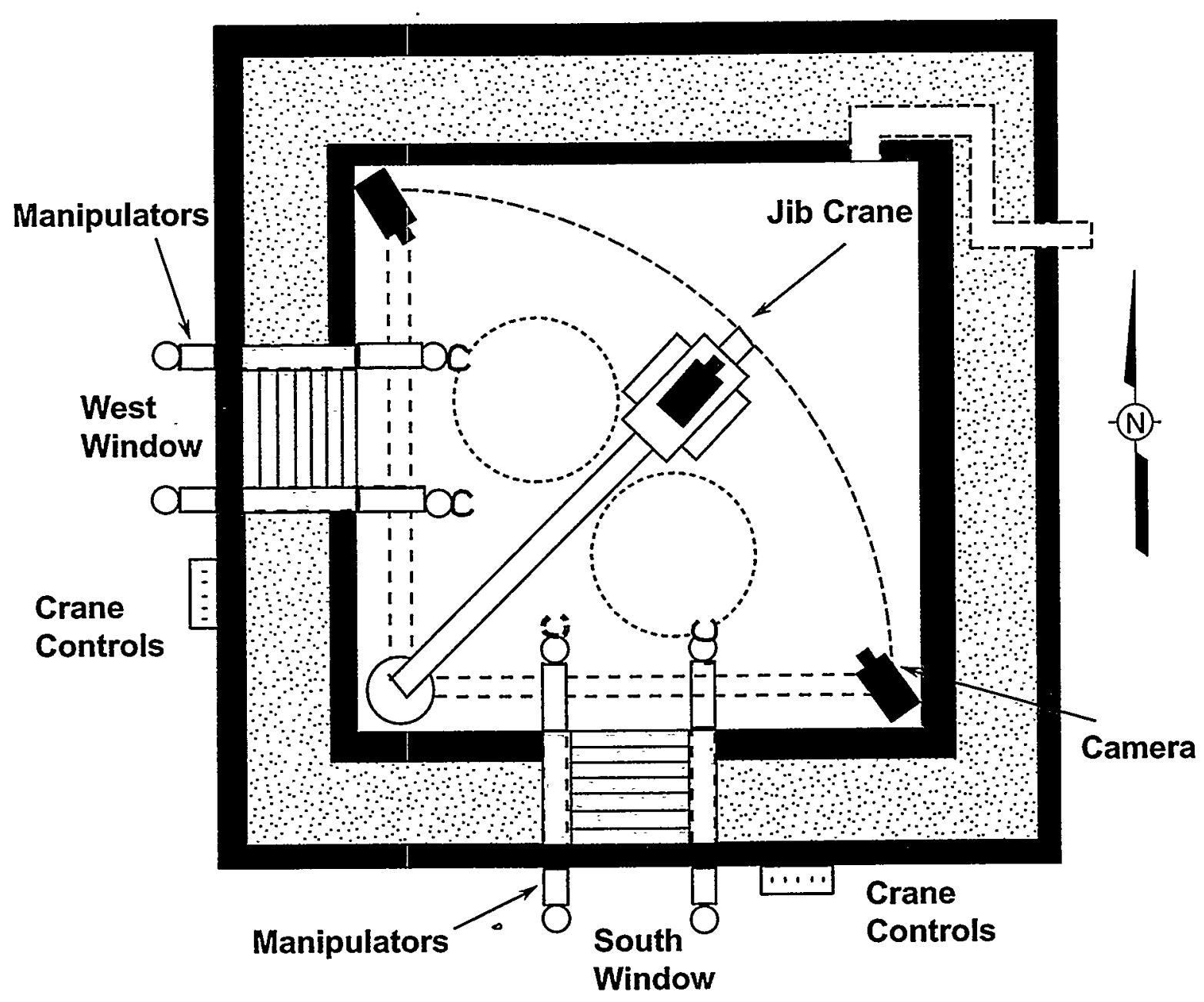

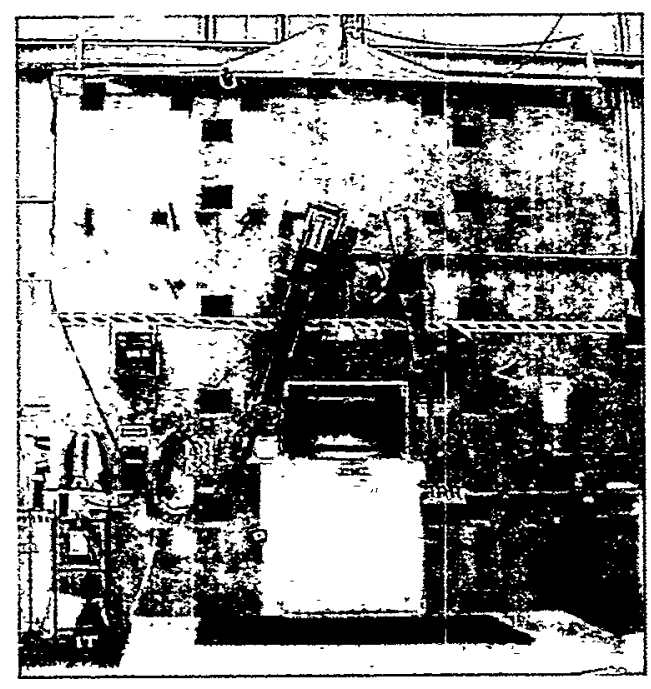

West Elevation

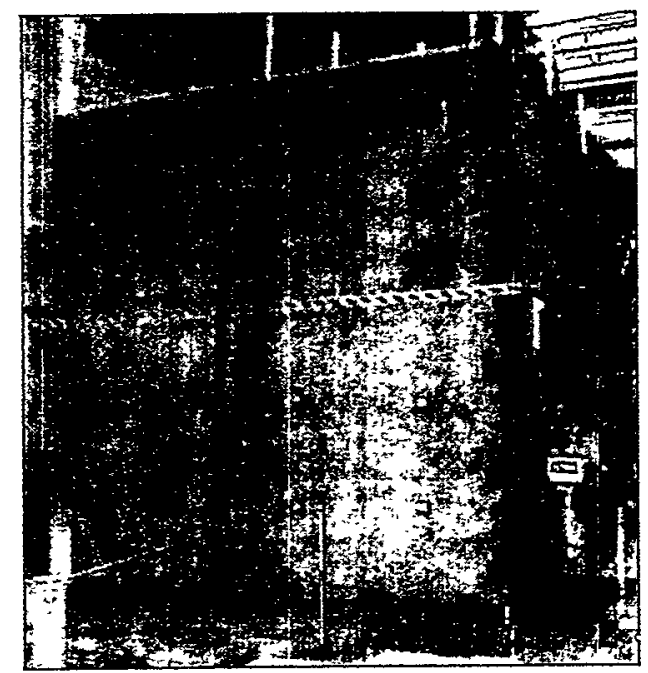

North Elevation

Figure 2-5. Hot Cell Process Equipment (SNL 1997). Camera locations are illustrative. 
cameras. All three cameras will be used to view and photograph package contents. Additional cameras may be used as needed.

The exterior cameras will be used to monitor the outside of the building on the east and north sides. All cameras except the camera mounted on the mezzanine scaffolding will be controlled at a console that sits on a platform by the hot cell. The monitor for the mezzanine camera will be behind the modular shield wall.

\subsubsection{Gamma Scanner}

A gamma scanner will be used to obtain a gamma profile of package contents. This nondestructive scanning technique provides a preliminary characterization of package contents. Two scanners will be available, a fixed dedicated system and a portable scanner.

\subsubsection{Instrumentation and Control Systems and Equipment}

As discussed in Sections 2.3.4 and 2.5.4, operations at the AHCF will be planned to accommodate individual packages on a case-by-case basis. No routine package-handling operations or processes are planned for the AHCF. Therefore, neither the fume hood nor the hot cell will have monitoring instruments or control systems that are geared toward routine processes.

There will, however, be recorders and intrusion monitors installed at the camera console mentioned in Section 2.5.2.5. This console will be equipped with intrusion monitors, motion detectors with audio and visual alarms, five recorders for the cameras in the High Bay and hot cell, quad and image splitters, a coax controller for the pan/tilt/zoom cameras, a time/date generator, and a microphone with line amplifier for recording the information gathered.

\subsubsection{Basic Process and Flow Diagram}

Figure 2-6 illustrates the basic process for handling materials or waste at the AHCF. Depending on what is already known about their contents, it may not be appropriate to treat every package identically; some packages may not need $\mathrm{x}$-radiography, for example. A preliminary assessment of each package will be made to determine a safe and appropriate handling plan.

An initial assessment of package contents will be made using process knowledge. Packages with contents falling below the Hazard Category 2 thresholds will be handled at the AHCF. After an assessment of the package's surface-dose rate, a plan for its safe handling and any expected short-term storage at the AHCF will be developed. This plan will be reviewed at several points in the process as characterization reveals more information about the packages, although for clarity the review steps are not shown in Figure 2-6. Most packages will have undergone a CSA at their previous location, and criticality potential during transport and short-term storage of the package will also be reviewed. 
After these preliminary assessments, packages could be moved directly from their initial storage location to Building 6597 for gamma spectroscopy, or they could be taken first to Building 6635 for $\mathrm{x}$-radiography and then to Building 6597 for characterization. In Building 6635 the $10-\mathrm{MeV}$ linear-accelerator $\mathrm{x}$-ray machine may be used to radiograph packages to determine the location and stacking order of their contents. This procedure would make it possible to plan how best to handle the contents of each package so as to minimize worker exposure in a manner consistent with ALARA principles. Packages that are in 208-liter (55-gal) drums or in smaller containers will probably be transported by truck from their present location to Building 6635 in TA-III. All SNL facilities, including Building 6635 and the linear-accelerator x-ray machine, maintain safety documentation as required by SNL's Integrated Safety Management Program, as implemented through Chapter 13 of SNL's Environmental Safety And Health (ES\&H) manual (SNL 1999b) and the RPPM (SNL 1999a), as appropriate.

Some processes may take more than one working day, in which case the package may have to be placed in short-term storage in an SNL Radioactive Material Area at the AHCF. Short-term storage is shown only once in Figure 2-6, although it could be necessary at more than one point in the process.

After radiography has been completed, the package will be transported to Building 6597 . At Building 6597 a one-dimensional, vertical gamma-ray scan will be made of each package. By analyzing the peaks in the energy spectrum and the intensity of the gamma rays, workers will be able to verify the types and locations of isotopes within each package. This process will again alert workers to unexpected contents or unexpected levels of activity.

Where a package is handled will be determined by assessing the package from process knowledge, radiography, and gamma scanning. Following the gamma scan, the container will be moved behind the shield wall adjacent to the hot cell. At this point there are several options. If the contact dose rate is less than RPPM limits and the package contains neither spreadable contamination nor reactive materials in excess of administrative controls, containers will be moved to the walk-in fume hood adjacent to the hot cell. Containers not suitable for handling in the fume hood will be moved into the hot cell itself if they will fit through the roof openings. Packages whose contact dose rates exceed the RPPM limits and that are too large for the hot cell will be handled remotely behind the shield wall. If necessary, a temporary room will be erected for contamination control.

Criticality potential must be reviewed again before re-sorting or repackaging to ensure that no critical assemblages are created during handling. Materials will be characterized, separated, sorted, and repackaged. Finally, materials that can be reused or recycled will be separated for shipment to reuse or recycling sites. If no reuse or recycling is possible, materials that meet the waste acceptance criteria (WAC) for an off-site disposal facility will be disposed of. In rare cases, materials may not be suitable for reuse, recycling, or disposal at this time. In these cases, materials will be repackaged and returned to storage. 


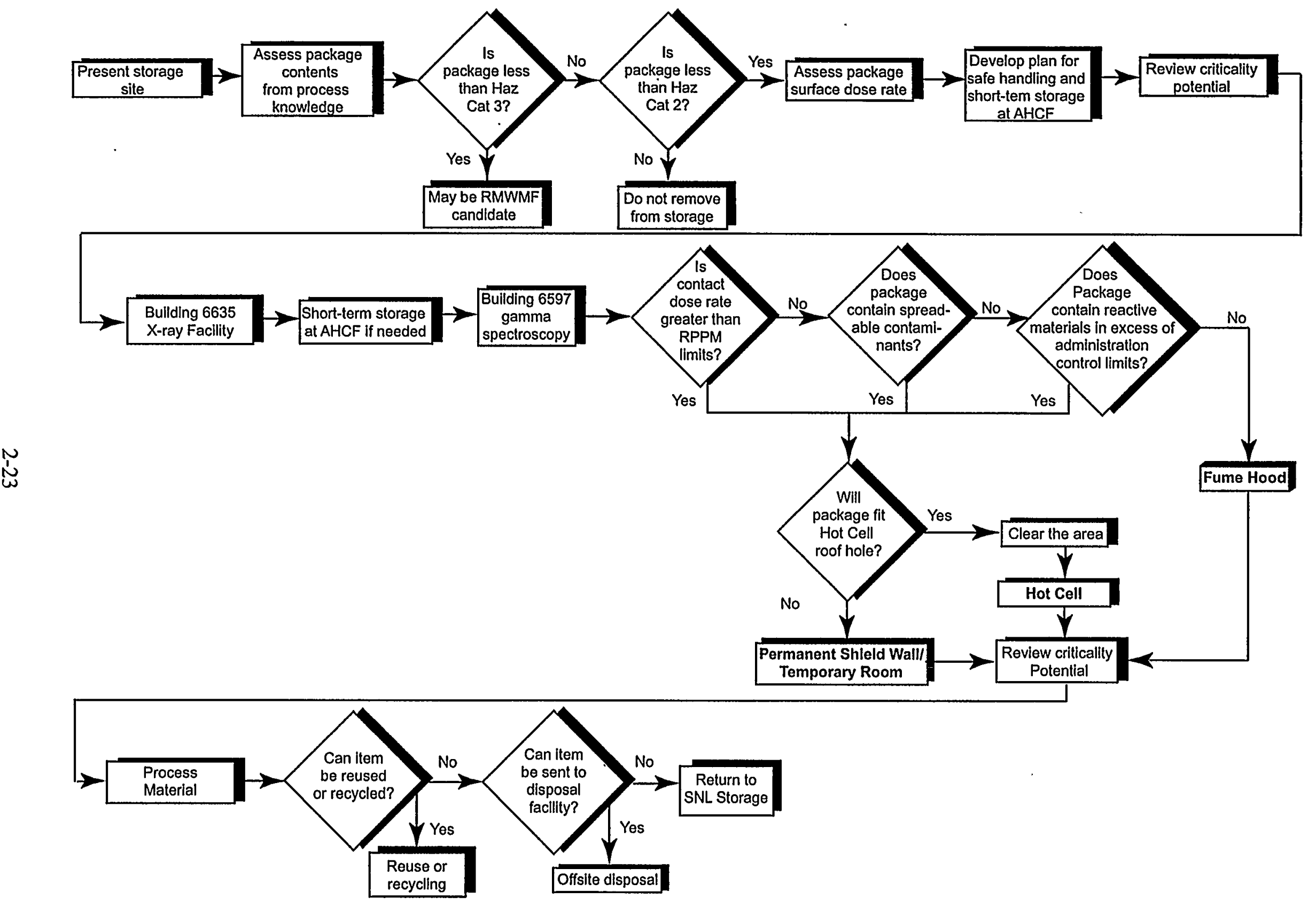

Figure 2-6. Flow Chart Showing Typical AHCF Process. 


\subsubsection{Materials and Radioactive and Mixed-Waste Processing at the Fume Hood}

The area north of the hot cell and east of the permanent shield wall houses the fume hood, which will be used for repackaging and characterizing waste in 55-gallon or smaller drums. If the package has a contact dose rate that can be managed on a package-specific basis in accordance with the RPPM limits (Sandia 1999a), is thought from process knowledge not to contain fine particulates, and does not contain reactive materials in excess of administrative control limits, the package will be introduced into the fume

hood. After a package has been characterized and repackaged, it will be moved out using the drum cart and set aside for disposition.

At the fume hood, containers will be opened and the contents removed one at a time. Each item will be photographed (with an electronic video camera) and inspected for integrity. When all of the contents have been removed and inspected, they will be either repackaged in the same container or sorted and placed in other containers, as appropriate. A detailed packing list (or log) will be made of the contents and locations of the materials in the containers. The containers will be resealed and labeled with documentation traceable to the packing list and photographs. Administrative controls will limit quantities of reactive chemicals (e.g., sodium) handled in the fume hood.

\subsubsection{Materials and Radioactive and Mixed-Waste Processing in the Hot Cell}

Before a container destined for the hot cell is moved from behind the shield wall, the overhead 5442-kg (6-ton) bridge crane will remove one of the plugs in the roof of the hot cell. Administrative controls will ensure that when roof plugs are removed from the roof ports, only one plug is placed on a given roof section at a time. After a roof plug is removed, the bridge crane will lift the container to the roof of the hot cell, and the chain hoist will lower it through the opening in the hot cell roof. Finally, the opening in the roof will be closed with the roof plug. During this process, the hot-cell exhaust system will continuously draw air from the hot cell into the HEPA filter exhaust train.

Once the hot cell is resealed and the exhaust system has reestablished the desired negative pressure ( 0.1 in. w.c.), any of the following activities could occur in the hot cell:

- Packages may be opened, using the manipulators and the jib crane, and visually inspected to verify contents and results of previous characterizations.

- Packages may be depressurized to satisfy U.S. Department of Transportation (DOT) requirements or the WAC of the final disposal site.

- Packages containing liquids may receive in-situ stabilization to satisfy WAC requirements at the final disposal site. 
- Package contents could be sorted and treated according to the following categories:

- TRU waste,

- Low-level waste,

- RCRA hazardous waste, and

- Reusable materials.

- All inventory will be photographed and logged.

After the packages have been resealed, the crane will remove the roof plug, pull the package out of the hot cell, and reseat the roof plug.

\subsubsection{Materials and Radioactive and Mixed-Waste Processing behind the Permanent Shield Wall and in the Temporary Room}

The area north of the hot cell and east of the permanent shield wall will be used for two distinct purposes. First, the area will be used as a staging area for radioactive packages arriving and leaving Building 6597 by truck or forklift. Packages may be introduced into the hot cell, fume hood, or temporary room from here. If the package has a contact dose rate greater than RPPM limits (Sandia 1999a), contains fine particulates, or contains reactive materials in excess of administrative control limits, it will be introduced into the hot cell, providing it fits through the roof opening and is within the weight limit of the hoist.

Second, if a package is unsuitable for the fume hood and does not fit through the roof opening of the hot cell, it will be handled remotely behind the permanent shield wall using manipulators. Packages arriving or leaving in shielded casks will be handled in this area using a forklift and 6-ton bridge crane. Such packages will be worked on remotely and stored in silos that are located in the floor. This area will also be used for the loading of packages into shielded shipping casks.

A temporary room will be set up behind the permanent shield wall for hands-on or remote handling of contaminated packages. The temporary room will be created as necessary to handle packages too large to fit through the opening at the top of the hot cell. Storage casks for intact fuel pins (such as Debris Bed Cask 1, Debris Bed Cask 2, and Gatling Gun) and wooden crates that contain experimental hardware are examples of packages that fall into this category. Any items that cannot be inspected from behind the shield wall without an additional layer of confinement will be inspected inside the temporary room. The temporary room will be vented through the AHCF HEPA filters. The characterization steps would be similar to those described for the hot cell and fume hood. 


\subsubsection{Post-Characterization Process}

After a package has been removed from either the fume hood, temporary room, or hot cell, it may again be placed behind the shield wall. Material declared to be waste will be prepared for final disposal according to DOT regulations and the WAC of the disposal facility.

If a package is suitable for shipping without further modification, it may be placed immediately into an appropriate shipping container, for example, a DOT Type A or Type B container.

Packages not suitable for immediate disposal will require some additional handling to bring them into compliance with DOT or waste-acceptance criteria. Some packages that belong in this category are as follows:

- Packages containing radionuclides, which may in some cases be slightly pressurized, must have enclosed volumes vented. Packages may be vented through the hot cell filter system before the packages can be placed in appropriate shipping containers. In some cases, closed-off vent tubes extend into the inner volumes, and filters will be attached to these tubes and the valves opened. In other cases, container walls may need to be drilled through and a vent tube attached. Following these operations, the items will be packed into suitable containers and then stacked into shipping casks.

- Any packages from the SPR Dense Pack that contain water will require treatment. After preparation, the packages could be inserted directly into shipping containers in Building 6597 or returned to temporary storage.

After characterization, packages will be sent to an appropriate TSD facility.

\subsubsection{Operational Considerations}

There are no special temperature requirements for the AHCF. There are no processing time requirements for the facility as a whole, although such requirements may be established for individual packages. Airflow from Zone 2 to Zone 1 or air-pressure differentials across the HEPA filter system, as appropriate, will be maintained to control contamination during operations in the hot cell, fume hood, or temporary room. The HEPA filter comes equipped with a standard device for measuring the pressure differential across the filter. A readout will be available to the operator. In addition, three meters to measure air flow will be installed: one will serve the temporary room and fume hood; one, the hot cell; and one, the ventilation stack. With this design, the airflow through the ventilation system can be determined with the combined information provided by these three airflow meters. A Technical Safety Requirements (TSR) will require tests to measure the pressure differential across the HEPA filter and filter efficiency. 


\subsubsection{Process/Design Safety Features}

Because safety is such an important consideration, process and design features that contribute to worker safety and environmental integrity are described in this section. In addition, radiation, criticality, and chemical safety are discussed in Section 2.7.

\subsubsection{Radiation Safety}

The Radiological Protection Program is administered in accordance with 10 CFR 835 (CFR 1998a), DOE orders, and ALARA principles. The SNL Radiological Protection Program is currently described in the ES\&H Manual (SNL 1999b) supplement, "Radiological Protection Procedures Manual" (SNL 1999a). The RPPM identifies engineering and administrative controls, including ALARA principles, for conducting radiological work in a safe manner.

Engineering controls have been included in the design and construction of the AHCF. The hot cell has been designed to shield operators from direct radiation and to minimize the spread of contamination. Engineering controls include wall construction, the ventilation system, and structural design.

All walls have been constructed to minimize radiation transmittance. All joints between interlocking pieces, wall-ceiling surface interfaces, and wall-foundation interfaces have been sealed and configured to prevent streaming through the full thickness of the shield wall. The maximum wall transmittance is $2.5 \mathrm{mrad} / \mathrm{hr}$ and the maximum ceiling transmittance is $100 \mathrm{mrad} / \mathrm{hr}$, given a $6.0 \mathrm{kCi}$ source of mixed fission products, 120 days postirradiation. The hot-cell floor is raised to prevent streaming under the wall panels. The window frames contain $6.4-\mathrm{cm}(2.5-\mathrm{in}$.)-thick steel plates to prevent streaming around the edges. The hot cell opens from the top; no access openings are present in the walls. This adds a second margin of protection for workers in the building.

Dose to workers on the cold side of the permanent shield wall will result from radiation shine reflecting from the ceiling, walls, and air in the AHCF as well as from transmittance through the wall. Bounding calculations show that the dose from shine can in some cases exceed $2.5 \mathrm{mrem} / \mathrm{hr}$; however, dose to workers will be managed on a packagespecific basis in accordance with the RPPM (Sandia 1999a).

The ventilation system will maintain a negative $\Delta^{P}$. Therefore, all air leakage is inward to prevent the spread of contamination. Air pressure differentials across the HEPA filter will be maintained during characterization and sorting activities in the hot cell, fume hood, and temporary room to prevent the release of contaminants.

The hot cell, permanent shield wall, and bracing of the ventilation system will meet Seismic Performance Category 2 requirements (DOE 1996a) and 1997 UBC requirements (ICBO 1997). Building 6597 is not seismically rated. 
Administrative controls will provide the second line of defense. Access to Building 6597 will be controlled when materials or waste are handled. Possible areas of exposure in the building and outside will be posted and labeled and will be monitored during material handling. Additional "good-practice" procedures based on ALARA principles have been developed to ensure worker safety.

Additional administrative controls include personnel dosimetry, control of radioactive material, use of personal protective equipment (PPE), and source control. The total inventory of materials and wastes being characterized in the AHCF at any one time will be below Hazard Category 2 threshold quantities. Inventories of mixed fission products are limited to $6.0 \mathrm{kCi}$ in the $\mathrm{AHCF}$ at any time.

\subsubsection{Criticality Safety}

Both an approved criticality safety procedure and an approved criticality safety assessment (CSA), each written in accordance with the guidance provided in SNL's Criticality Safety Supplement to the ES\&H Manual (Philbin 1998), will govern operations at the AHCF whenever fissile inventory exceeds the fissile inventory threshold amounts described in the Supplement. The threshold amounts that require formal procedures and a CSA are as follows:

- $700 \mathrm{~g} / 350 \mathrm{~g}$ for solid/aqueous forms of U-235,

- $520 \mathrm{~g} / 260 \mathrm{~g}$ for solid/aqueous forms of U-233, and

- $450 \mathrm{~g} / 225 \mathrm{~g}$ for solid/aqueous forms of Pu-239 and/or Pu-241, or

- $450 \mathrm{~g} / 225 \mathrm{~g}$ for solid/aqueous forms of any combination of the fissile species (U-235, U-233, Pu-239, and Pu-241), as discussed in the Supplement.

\subsubsection{Chemical Safety}

The amount of hazardous chemicals at the AHCF is expected to be minimal, occurring primarily as minor constituents of the waste. These constituents may include trace solvents, toxic metal components, small amounts of uranyl nitrate, and uranium hexafluoride. There could also be some industrial-type chemicals (solvents and the like) and acids or bases used for neutralization. Workers will wear appropriate PPE at the fume hood when characterizing waste or materials containing hazardous chemical components in accordance with SNL's ES\&H manual (SNL 1999b, Chapter 6).

\subsubsection{Process Equipment Safety}

Cranes will be operated in accordance with SNL's ES\&H manual (SNL 1999b, Chapter 4, Section 4J). Truck transportation of wastes and materials to and from the building will comply with the ES\&H manual (SNL 1999b, Chapter 12). Fork lift operators transporting wastes and materials between TA-V storage sites and Building 6597 or between areas in Building 6597 will comply with ES\&H manual (SNL 1999b, Chapter 4, Section 4I). 


\subsection{CONFINEMENT SYSTEMS}

This section describes the structures, systems, and components that perform confinement functions, such as the facility walls, containers, and the ventilation system.

Building 6597 provides protection from the elements (rain, wind, and the like), as does any DOE-owned industrial structure. It does not serve either as a containment boundary or as a confinement barrier to the release of radioactive contamination. The walls and roof of the building do not serve as radiation shields and their attenuation effects are not considered in the analysis of radiation doses.

\subsubsection{Hot Cell Confinement}

The hot cell is one of the primary confinement systems. The design of and the construction materials used in the hot cell, which have been discussed in detail in Sections 2.4.2 and 2.5.6, meet or exceed those needed for the dose rates that will be encountered in characterizing and sorting the proposed inventories.

\subsubsection{Materials/Waste Container Confinement}

Legacy materials and wastes are most often stored in strong, tight containers, such as those listed below:

- Steel drums,

- Steel boxes,

- Wooden crates,

- Plastic containers,

- Casks, and

- Cylinders.

Although packages containing new materials may vary from those listed below, packages currently containing legacy materials can be grouped into the following categories:

- Unirradiated items contained in 7.6-liter (2-gal) to 208-liter (55-gal) packages;

- Low-contact-dose items ( $<40 \mathrm{mrem} / \mathrm{hr}$ ) in 7.6-liter (2-gal) to 265-liter (70-gal) drums, some contained in tall, small-diameter cylinders;

- High-contact-dose items ( $>100 \mathrm{mrem} / \mathrm{hr}$ ), mostly in 208-liter (55-gal) drums, but some contained in tall cylinders; and

- Tall, small-diameter experiments having a high contact dose $(>100 \mathrm{mrem} / \mathrm{hr})$. 
Some containers may contain secondary containers. In addition, some containers may contain shielding materials to reduce the surface radiation levels below cutoff limits. For contact-handled containers to be shipped off site, acceptable limits are less than 200 $\mathrm{mrem} / \mathrm{hr}$ at the package surface. (The WAC of some disposal sites [e.g., Waste Isolation Pilot Plant WAC] prohibit the use of shielding to meet surface radiation requirements. Containers destined for such sites must meet the $200 \mathrm{mrem} / \mathrm{hr}$ limit without shielding; shielding may be added to meet ALARA guidelines.)

\subsubsection{Fume Hood Confinement}

The types of hazardous and radioactive materials examined at the fume hood will vary with the contents of the packages being characterized. Material types are listed in Sections 2.5.1.1 and 2.5.1.2. Hazardous materials present in mixed waste may be caustic, toxic, or reactive.

The exhaust system provides primary confinement at the fume hood. An administrative control will ensure that the temporary room and walk-in fume hood will not operate simultaneously.

\subsubsection{Ventilation/Filtration System Confinement}

The exhaust system for Building 6597 (Zone 2) is separate from that of the hot cell, fume hood, and temporary room (Zone 1). The Zone 1 AHCF ventilation system, which provides confinement typical of that for gloveboxes, is a stand-alone system. It does not tie into Building 6597 mechanical systems. The ventilation system and HEPA filters are two of the five safety-significant components of the AHCF.

One exhaust system, shown in Figure 2-7, will serve the Zone 1 components (SNL 1998b). The exhaust system will exhaust at a variable rate of 1740 to 3360 acfm for the fume hood, $700 \mathrm{acfm}$ for the hot cell, and $600 \mathrm{acfm}$ for the temporary room through a two-stage HEPA filter train (Figure 2-7). An additional HEPA pre-filter will treat exhaust from the hot cell before it enters the main HEPA filter train. The system will use a 10-hp exhaust fan maintained at an 20-cm (8-in.) external static pressure by a variable frequency drive (VFD) or a variable inlet vane (VIV). The exhaust system will be capable of maintaining airflow from Zone 2 to Zone 1 in the fume hood and temporary room.

A control system will be incorporated into the exhaust system design to allow selection of each of the three exhaust streams. The only three possible exhaust streams are the hot cell alone; the hot cell plus walk-in fume hood; or the hot cell plus temporary room. No exhaust stream from the fume hood and temporary room simultaneously is possible, because a switch controlling the damper system prevents the two from being operated at the same time. Only one airflow-measuring device is needed for the fume hood and temporary room. Administrative controls will ensure that the fume hood and temporary 


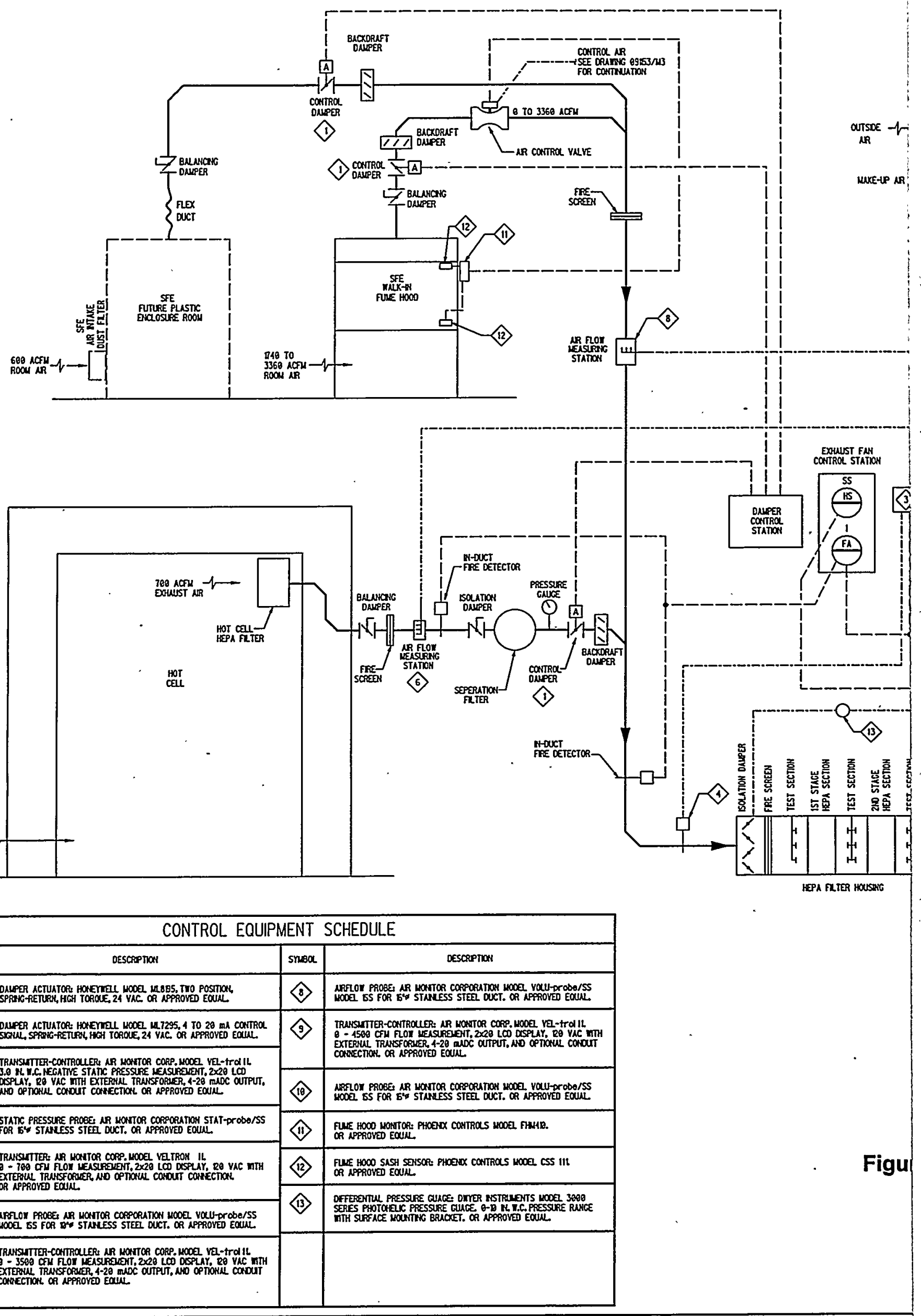




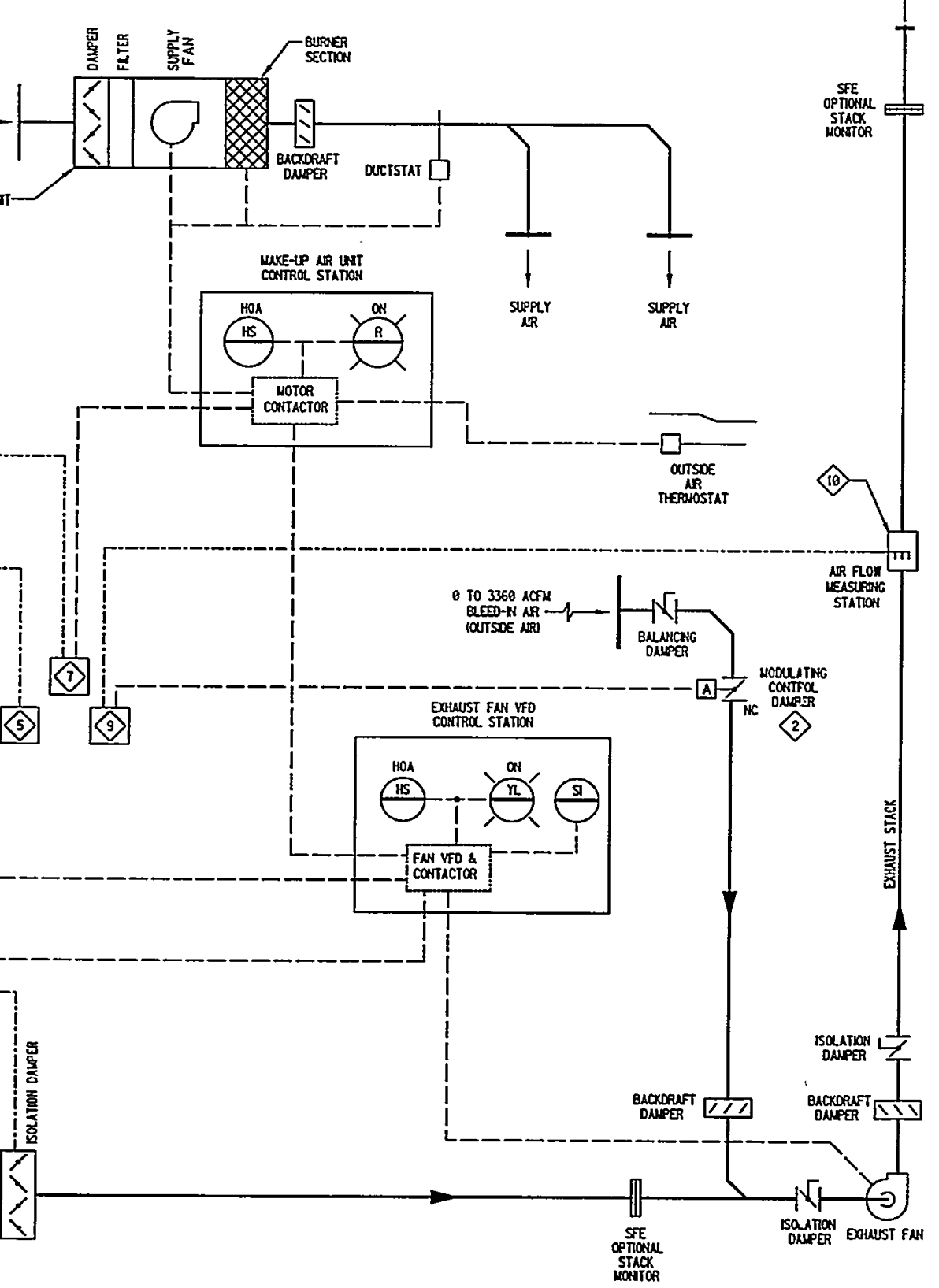

2-7. HEPA Filter Train.
SEQUENCE OF OPERATION

\section{TELPCRAYY PLASTICS ROOLE}

AFFLOI FROU TFE ROOU IIL BE CONTROLDO BY A CUT-OFF DUPER WMCH TLL BS

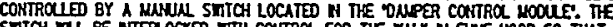

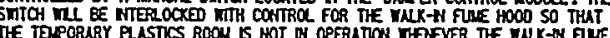
HOOO IS $\mathrm{W}$ OPERATOH

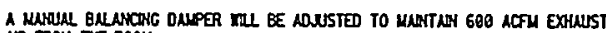
ATR FROU TIE ROOU

WWK-H Fure HOOO:

THE SMTCH TLL QE MTERLOCEED ITTH COHTRO FOR TTE TEMPORLAY PLASTICS

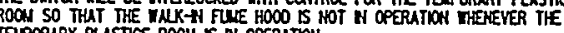

VEOATY SENSORS (ORE $N$ ERCH SASH AREN WE TUE HOOO FACE ML

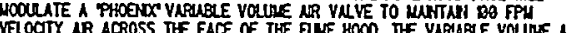

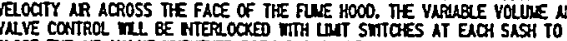
COOSE THE AR VLVE WEEVE BOTH SASHS ARE COOSED.

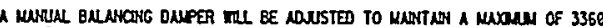
ACFU EXUUST UR FROH TRE HOOOD.

HOT Cals:

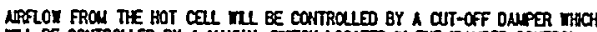
ROCWE.

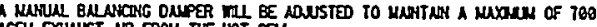
ACFU EXUUST AR FROM THE HOT CEL

HEPA SYSTEX EXHAUST FNL:

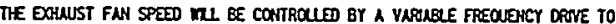
FRTER PLGiul

STRCK DXHuUST:

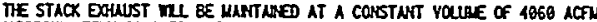

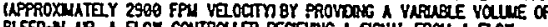
BLEED-N AR. A FLON CONTROLGR FECEREG A SGHL ERON A FLO

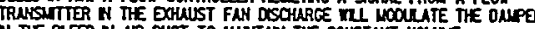

MNKE-QP NR UNIF

TIE WAKE-LP AR WNT ITL OPERATE UDER THE FOLOWNG COHOMONS: I THE OUTSOE AR TEYPCRATUFE IS LESS THWN 65\%. AH OUTSDE AR TRASUTTER THROSGH A TERPERTURE HOCATHE CONTROUER ML PROVDE THS NTERLOCK.

2. THE EXUUST FAN IS OFERTIOWLL.

3. AR FLOU FRON TE WLXXN

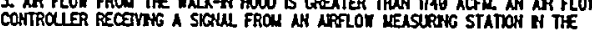
EXHUUST DUCT FRON TIE HOOO WIL PROVDE THS WTTELOC.

4. THE UAKE-LP NR UNT FAN WU BE OPERATED OH LON SPEDD ULESS TE Whe $1 T$ TCH SPEB

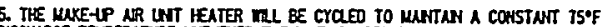
OTSCHARGE TEMPERATURE WEEEYER THE WNT IS OPERATORLL.

\section{LEGEND}

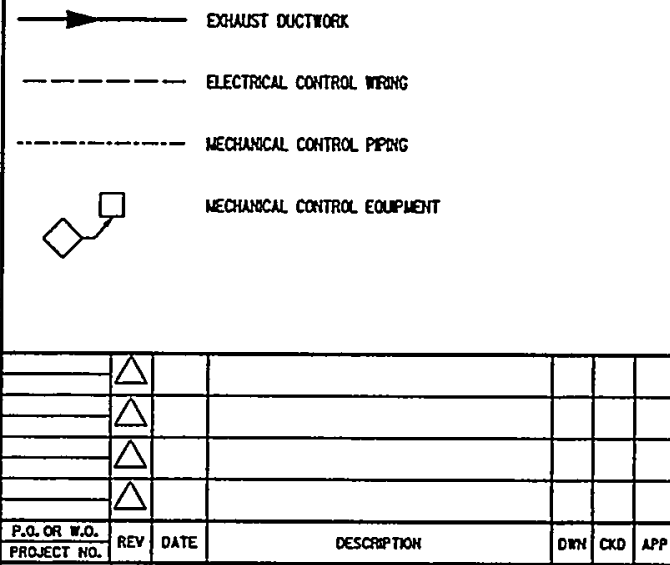
U.S. DEPARTMENT OF ENERGY

KRTUNO ABEA OFFCE SANDIA NATIONAL LABORATORIPS

in
AHCF AI FLOW CONTROL DIACRAM

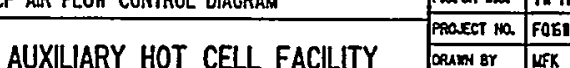
MODIFICATIONS

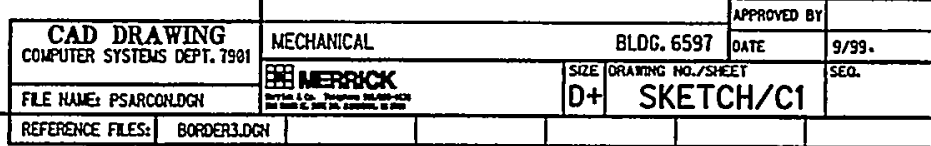




\subsubsection{Fire Protection}

The High Bay of Building 6597 will be protected by wet-pipe sprinkler and fire-detection systems installed in accordance with applicable codes and standards. Each of these separate detection and suppression systems will report to the building alarm system, which interfaces with the TA-V evacuation system and SNL/NM's fire alarm systems. The Kirtland Air Force Base Fire Department is the primary response unit.

\subsubsection{Building 6597 Fire Protection}

Wet-pipe sprinkler and fire-detection systems will be installed. Water from sprinkler flow and firefighting operations will be collected in the building trench system, which was originally constructed to capture oil (Figure 2-8). Overflow from the trenches will be collected in an outside spill tank. The collection capacity of High Bay trenches is 160,000 liters (42,000 gal); Mid Bay trenches, 110,000 liters (30,000 gal); and outside spill tank, 64,000 liters $(17,000 \mathrm{gal})$. The entire containment system has an approximate capacity of 340,000 liters $(89,000 \mathrm{gal})$. The AHCF sprinkler system is capable of producing a flow of 750 gallons/minute. The trench system is adequate to contain all fire protection water generated by 118 minutes of flow. Water collected in the trenches and spill tank will be sampled and disposed of properly.

The fire alarm system is a zoned system with manual pull stations, fire detectors, water flow switches, alarm strobes, and bells. Manual pull stations are located at the exit doors. Fire detectors, located throughout the High Bay, provide redundant fire protection. Alarm notification appliances are installed throughout Zone 2 to provide early warning to building and site occupants. The sprinkler system and fire detector are supervised by the fire alarm system.

The fume hood (Zone 1) will obstruct the spray pattern of the overhead sprinklers. Therefore, an additional sprinkler will be installed under the fume hood to provide sprinkler protection for this area. The temporary room that will occasionally be erected in Zone 1 when work needs to be performed on large packages also obstructs the spray patterns of overhead sprinklers. A branch line that drops down from the main building sprinkler system will be used when the temporary room is present. The exhaust ducts and HEPA filter trains from Zone 1 will not be equipped for fire suppression.

\subsubsection{Hot Cell Fire Protection}

A fire in the hot cell is extremely unlikely. Identified combustibles are plastic bags, herculite cloth, rad wipes, wire insulation, and paints or epoxies used on surfaces. None of these if burned is of sufficient quantity to affect the majority of hot-cell contents. For this reason and other factors addressed in Chapter 3, both the probability of a fire occurrence and the potential thermal energy available to release radioactive material are significantly diminished. 

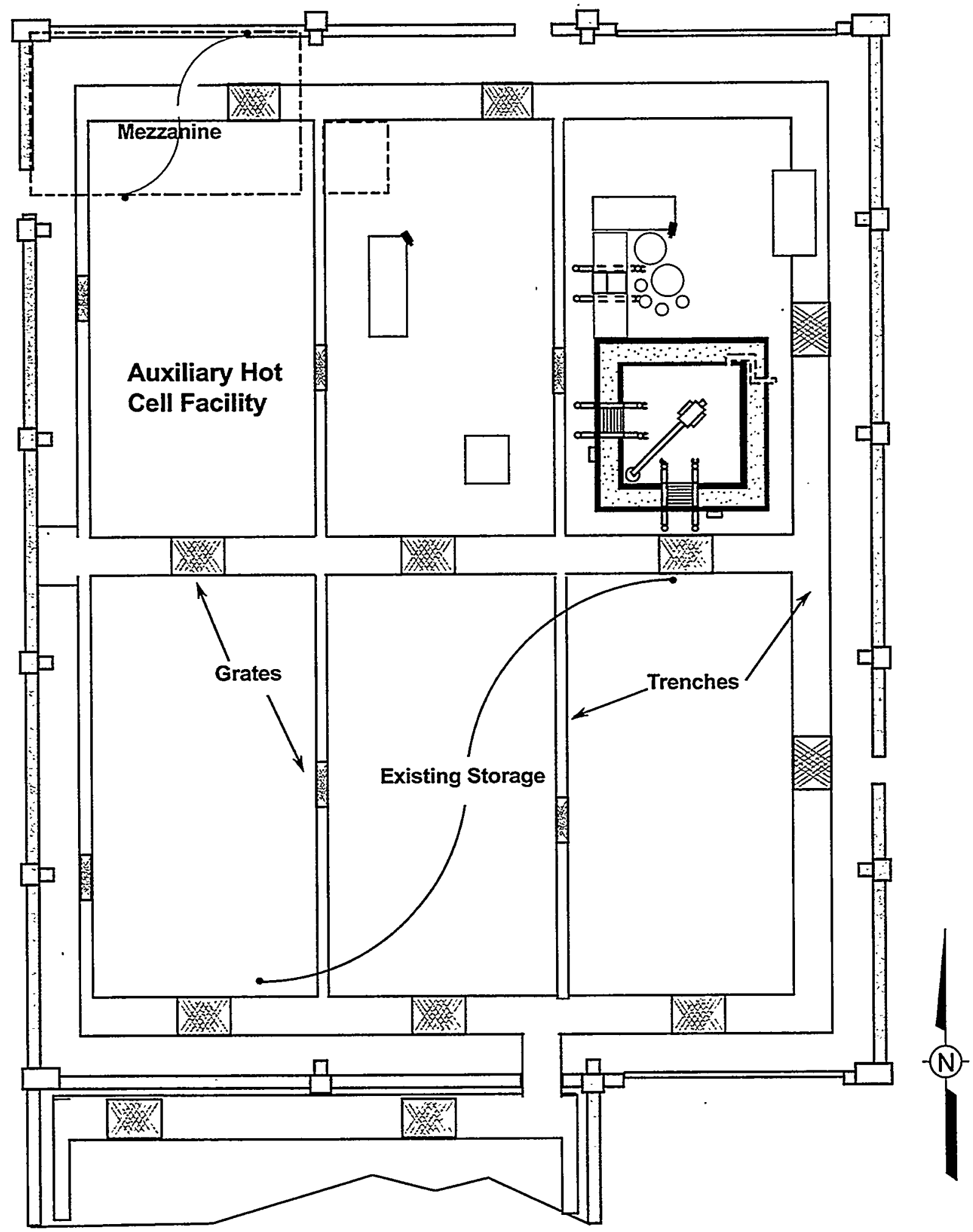

Figure 2-8. Building Trenches. Locations of cameras and modular shield walls are illustrative and may be changed on a package-by-package basis. 
The hot cell will be protected by a combination of detection and manual suppression systems. The Zone 1 exhaust duct will have a duct fire detector. The duct fire detector will report to the building fire alarm system and to the KAFB fire-response team.

A manual extinguishing system will be available to combat fires in their incipient stages. A wand inside the hot cell, consisting of a metal, braided hose, will be connected to a port outside the hot cell. Should there be a fire, a clean-agent (nonaqueous) fire extinguisher will be connected through a "quick connect" to the port. The hot-cell operator, holding the wand with the manipulator arms, will direct the agent at the base of the fire. The extinguishing system is a local application system and can be used only on small fires. The hot cell exhaust system will remain "on" during an internal fire and during discharge of the suppression agent. The clean agent, a halon replacement, leaves no residue and provides good visibility during discharge. The ventilation system will remain on to prevent the potential pressurization of the hot cell and possible contamination of the High Bay by the escape of the products of combustion through ports and other openings in the hot-cell walls. Furthermore, this arrangement will protect the operator from exposure to airborne contaminants while trying to put out the fire. It will be possible to turn the ventilation system off manually if the operator or fire-fighting personnel determines that such a course is appropriate. Written procedures will detail this sequence of activities and how to carry them out.

In the event that manual fire suppression by the operator is unsuccessful, the KAFB Fire Department will put out the fire. Piping will be constructed in the high sidewall to provide an avenue for the introduction of water into the hot cell if necessary to put out the fire.

Metal-X, a powdered extinguishing agent for smothering pyrophoric-metal fires, will be placed within reach of the manipulators inside the hot cell when pyrophoric metals will be present.

\subsubsection{Criticality Monitoring}

Criticality issues will be managed by administrative procedures, which must be reviewed by the TA-V Radiological and Criticality Safety Committee (RCSC). Monitoring will be performed by a portable criticality monitor as required by the Criticality Safety Assessment.

\subsubsection{Radiological Monitoring}

A radiation monitoring system for the AHCF has been designed to detect the presence of ionizing radiation and to alert personnel within the building. The system consists of Remote Area Monitors (RAMs), Continuous Air Monitors (CAMs), and personal dosimeters. Both the RAMS and the CAMs will set off alarms if gamma dose rates or airborne contamination rates exceed set points. 


\subsubsection{Contamination Prevention}

Accidental or abnormal exposures to both direct radiation and contamination are mitigated by the AHCF design features. Several hot cell design and operational provisions help prevent and mitigate the spread of contamination:

- The hot cell is opened from the top; therefore, contaminants should settle inside the hot cell.

- The ventilation system maintains a negative ${ }_{\Delta} P$. Therefore, all leakage is inward and contamination spread is prevented.

- Equipment located in the hot cell is limited to that which is necessary for repackaging and monitoring.

The design and operation provisions of the hot cell also make decontamination procedures easier. In particular, the old hot-cell liner will be removed, and a new liner with the following characteristics will be emplaced:

- The inner walls, floor and ceiling are covered by a removable membrane liner that has been made continuous.

- The surface of the membrane allows for easy wiping and removal of contamination.

- The membrane consists of $1.2-\mathrm{m}$ by $2.4-\mathrm{m}$ ( $4-\mathrm{ft}$ by $8-\mathrm{ft}$ ) sheets of galvanized-steel sheets glued to the inner concrete panels. These sheets can be collapsed and disposed of.

All other equipment used inside the hot cell is either disposable or covered with herculite cloth.

\subsubsection{Air Monitoring}

Particulates that might be present in the material or waste characterized at the AHCF will be entrained in the HEPA filter system. The CAM will monitor air in the High Bay as appropriate.

\subsubsection{Chemical Monitoring}

The operations planned for the AHCF will not be chemically intensive. There is limited potential for airborne chemical exposures to workers to exceed OSHA limits, as described in 29 CFR 1910.1000. Therefore, workplace monitoring for chemicals will be done as required by the work plan. 


\subsubsection{Effluent Monitoring}

Characterization and sorting of materials and wastes at the AHCF will not generate liquid effluents. There are no sanitary sewage systems in the AHCF. Restrooms are located in the building adjoining Building 6597. Therefore, effluent monitoring is not required.

If a fire were to occur in Building 6597, water from the building sprinkler system would be collected in the building trench system. Water collected in this system would be characterized before being collected in barrels or discharged.

\section{$2.8 \quad$ UTILITY DISTRIBUTION SYSTEMS}

This section provides a schematic outline of the basic utility distribution systems, including a description of the off-site power supplies and on-site components of the system.

\subsubsection{Power and Light}

The primary source of electrical power for TA-V is the Public Service Company of New Mexico transmission and distribution system, which supplies power at primary voltages of $345 \mathrm{kV}, 115 \mathrm{kV}$, and $46 \mathrm{kV}$. This power is supplied to SNL/NM facilities through one substation, the Sandia Switching Station.

\section{-2.8.1.1 Building 6597 Power and Light}

Preferred power for TA-V is normally transported over one $46 \mathrm{kV}$ transmission line that originates directly from the secondary side of the Sandia Switching Station. A second transmission line of equal capacity parallels the preferred line. A similar transmission scheme of parallel lines transports power to the Substation 17 in TA-V, from which voltage is stepped down to $4160 \mathrm{~V}$ for distribution to all other TA-V unit substations. Each TA-V unit substation is made up of a $5 \mathrm{kV}$ switch (or switches) and a transformer that steps the power down further. Transformer 6591-1 serves the panels in Buildings 6591 and 6597 . The power is first sent to a 277/480 V panel in Building 6597. There the power is transported to various smaller transformers and panels (120/208 V) throughout the two buildings.

Current lighting in the High Bay is supplied by $2.4-\mathrm{m}$ (8-ft) long fluorescent lamps. Interior lighting is controlled by switches at the entrances to each space. Exterior lighting, provided for security, is supplied by sodium lamps. The building perimeter is illuminated to a minimum of $0.2 \mathrm{fc}$.

Lamps on the south side of the High Bay and to the west of the hot cell will illuminate these areas at a level of $30 \mathrm{fc}$. Spot lighting for the fume hood/silo area will be provided at $100 \mathrm{fc}$. 
General emergency lighting with a minimum of 90 minutes backup capability will be provided at $0.1 \mathrm{fc}$ along the paths of egress. Night lighting at approximately $0.1 \mathrm{fc}$ will be provided throughout the work area. New emergency battery pack exit signs will be installed at each exit door.

Backup power to the chain hoist will be required only during the short periods that the bridge crane is being used for an in-air transfer of an exposed radiation source that presents an unacceptable hazard as defined by the RPPM. The bridge crane locks in place and is inoperable during a power outage. Portable generators will provide backup power to the chain hoist whenever the bridge crane is in use; the chain hoist and, if necessary, tethers will be used to lower any suspended packages to a safe configuration until power returns. Administrative controls will ensure that backup power for the chain hoist is available during in-air transfers. No other AHCF systems require redundant power supplies.

\subsubsection{Auxiliary Hot Cell Facility Power and Light}

The electrical power design uses components approved by Underwriters Laboratory (UL) to provide a reliable system to reduce the potential for outage during the operation of the $\mathrm{AHCF}$. The AHCF power requirements are satisfied by and are an extension of the existing 208/120-V power panel located on the east wall of Building 6597. No additional circuit breakers are necessary at this time. Additional conduit will be put in place as necessary to accommodate all power needs. Some of the major AHCF power requirements are listed below.

- Hot Cell and Fume Hood Power: Power is required for the lighting, jib crane, manipulators, cameras, and power tools, which have the following load estimates:

- Lighting: 19.6 amps at $120 \mathrm{~V}$;

- Jib crane: 10.6 amps at $208 \mathrm{~V}$ 3-phase (estimated) for power and 3 amps at $120 \mathrm{~V}$ for controls;

- Manipulators: $120 \mathrm{~V}$;

- Cameras: $120 \mathrm{~V}$; and

- Power tool receptacles: $120 \mathrm{~V}$.

- Hot Cell Lighting: The hot cell lighting is as follows:

- The lighting requires four 250-watt lights to provide $200 \mathrm{fc}$ on the horizontal plane at $7.6 \mathrm{~cm}(3 \mathrm{in}$.) above the floor. 
- The system uses five 250-watt metal halide fixtures located inside the hot cell on the ceiling.

- The design takes into account the effects of radiation within the hot cell.

- For redundancy, the system is capable of providing up to 2.5 times the light levels required for operations.

- Ventilation System: Control equipment for the ventilation system is shown in Figure 2-7. The ventilation system has the following major power requirements:

- The 10-hp motor for the ventilation system exhaust fan will require $480 \mathrm{~V}, 3-$ phase power and control wiring; and

- Balancing and backdraft dampers: $120 \mathrm{~V}$;

- Bridge Crane: The Building 6597 6-ton bridge crane: $440 \mathrm{~V}$ (taken off the $480 \mathrm{~V}$ line), 3-phase power and control wiring; and

- MUA Unit: The 3-hp motor for the MUA unit will require $480 \mathrm{~V}$, 3-phase power and control wiring.

\subsubsection{Domestic and Process Water}

The existing potable water service to Building 6597 will be used. Additional potable water service is not required. No additional water demands are generated by this project.

\subsection{AUXILIARY SYSTEMS AND SUPPORT FACILITIES}

This section provides general information on the other systems or support facilities that pertain to the hazard and accident analyses.

\subsubsection{Security Systems}

In addition to the main gate access controls, TA-V has an additional set of access controls. These access controls, which have been described in detail in Chapter 1, include security chain-link fences and gates manned by the SNL/NM Security Force (SNL 1995) (see Figure 1-3). In addition, Building 6597 has locked and alarmed doors. Even if nonauthorized personnel somehow gained access to the building, the 5000-pound roof plugs prevent entry to the hot cell, because the bridge cranes will be locked out. 


\subsubsection{Communication Systems}

Building 6597 has a telephone and an emergency public address (PA) system. Because no one will be routinely working inside the hot cell, no communications system is required for that structure. Voice communication, both direct and by radio, will be adequate for activities in Building 6597.

\subsubsection{Medical Support}

Medical support is available 24 hours a day through the 911 system. The SNL/NM Benefits and Medical Services Center operates a clinic in TA-I. The staff maintains appropriate licenses and the facility is periodically audited. Injured or contaminated personnel may be transported to this clinic by ambulance or to any one of the four major hospitals in the Albuquerque area.

\subsection{REFERENCES}

(ACGIH 1998) American Conference of Governmental Industrial Hygienists, "Threshold Limit Values for Chemical Substances and Physical Agents and Biological Exposure Indices," ACGIH, Cincinnati, OH, 1998.

(ANSI 1997)

(ANSI/ANS 1988)

(CFR 1998a)

(CFR 1998b)

(CFR 1998c)
American National Standards Institute, "National Electrical Safety Code," ANSI C2-1997, American National Standards Institute, New York, NY, 1997.

American National Standards Institute/American Nuclear Society, "Nuclear Criticality Safety in Operations with Fissionable Materials Outside Reactors," ANS-8.1-R1988, American National Standards Institute, New York, NY, 1988.

Code of Federal Regulations, "Occupational Radiation Exposure," Title 10, Part 835, Office of the Federal Register, National Archives and Records Administration, Washington, DC, January 1, 1998.

Code of Federal Regulations, "Occupational Safety and Health Standards," Title 29, Part 1910, Office of the Federal Register, National Archives and Records Administration, Washington, DC, July 1, 1998.

Code of Federal Regulations, "Basic Program Elements for Federal Employee Occupational Safety and Health Pro- 
(DOE 1998)

(DOE 1996a)

(DOE 1996b)

(DOE 1995)

(DOE 1994a)

(DOE 1994b)

(DOE 1994c)

(Duong 1999)

(FR 1980) grams and Related Matters, Title 29, Part 1960, Office of the Federal Register, National Archives and Records Administration, Washington, DC, July 1, 1998.

U.S. Department of Energy, DOE Order 440.1A "Worker Protection Management for DOE Federal and Contractor Employees," U.S. Department of Energy, Washington, DC, March 27, 1998.

U.S. Department of Energy; DOE Standard-1020-94, "Natural Phenomena Hazards Design and Evaluation Criteria," Chg. 1, U.S. Department of Energy, Washington, DC, January 1996.

U.S. Department of Energy, DOE Order 420.1, Chg. 2, "Facility Safety," U.S. Department of Energy, Washington, DC, October 24, 1996.

U.S. Department of Energy, "Environmental Checklist/ Action Description Memorandum," U.S. Department of Energy Albuquerque Field Office, Albuquerque, NM, February 1995.

U.S. Department of Energy, DOE Standard 3009-94, "Preparation Guide for U.S. Department of Energy Nonreactor Nuclear Facility Safety Analysis Reports," U.S. Department of Energy, Washington, DC, July 1994.

U.S. Department of Energy, DOE Order 5480.23, Chg. 1, "Nuclear Safety Analysis Reports," U.S. Department of Energy, Washington, DC, March 10, 1994.

U.S. Department of Energy, DOE Standard 3009-94, "Preparation Guide for U.S. Department of Energy Nonreactor Nuclear Facility Safety Analysis Reports," U.S. Department of Energy, Washington, DC, July 1994.

Duong, H., "Shielding of Hot Cell Ceiling," Memorandum to Debby Oscar, Sandia National Laboratories, Albuquerque, NM, July 26, 1999.

Federal Register, Executive Order 12196, "Occupational Safety and Health Programs for Federal Employees," 45 FR 12769, Office of the Federal Register, National Archives 
and Records Administration, Washington, DC, February 26, 1980 .

(ICBO 1997)

(Lipinski et al. 1999)

(NFPA 1999)

(NFPA 1997)

(Philbin, 1998)

(SNL 1999a)

(SNL 1999b)

(SNL 1998a)

(SNL 1998b)

(SNL 1997)
International Conference of Building Officials, 1997 Uniform Building Code, International Conference of Building Officials, Whittier, CA, April 1997.

Lipinski, R. J., R. X. Lenard, and G. A. Harms, Preliminary Characterization of Materials in Manzano Storage Bunker 37055, SAND99-0182, Sandia National Laboratories, Albuquerque, NM 87185, 1999.

National Fire Protection Association, "National Electrical Code," NFPA 70-1999, National Fire Protection Association, Quincy, MA, 1999.

National Fire Protection Agency, Life Safety 101, "Industrial Special Use Occupancy," National Fire Protection Agency, Quincy, MA, 1997.

Philbin, J. S., "Nuclear Criticality Safety," GN470072, Issue C, Sandia National Laboratories, Albuquerque, NM, January 28, 1998.

Sandia National Laboratories, "Radiological Protection Procedures Manual," CPR400.1.1.32, Sandia National Laboratories, Albuquerque, NM, January 21, 1999.

Sandia National Laboratories, "Environmental Safety and Health Manual," MN471001, Issue CE, Sandia National Laboratories, Albuquerque, NM, March 1, 1999.

Sandia National Laboratories, "Temporary Hot Cell Modifications for the Remediation Of Legacy WasteBuilding 6597," Sandia National Laboratories, Albuquerque, NM, April 22, 1998.

Sandia National Laboratories, "Advanced Design Criteria for the Auxiliary Hot Cell Facility Modifications Building 6597," Sandia National Laboratories, Albuquerque, NM, December 21, 1998.

Sandia National Laboratories, "Unreviewed Safety Question Determination for Operation of Temporary Hot 
Cell," Sandia National Laboratories, Albuquerque, NM, January 22, 1997.

(SNL 1996)

Sandia National Laboratories, "Performance Criteria for the Design and Construction of a Temporary Hot Cell Facility," Sandia National Laboratories, Albuquerque, NM, June 11, 1996.

(SNL 1995)

Sandia National Laboratories, Hot Cell Facility-Safety Analysis Report, SAND94-2650, Sandia National Laboratories, Albuquerque, NM, December 1995. 


\section{ChAPTER 3}

\section{HAZARD AND ACCIDENT ANALYSIS}

\section{$3.1 \quad$ INTRODUCTION}

The purpose of this chapter is to provide a comprehensive evaluation of the hazards potentially affecting the AHCF in characterizing, treating, and repackaging radioactive waste and materials for reuse, recycling, or transport to off-site facilities for final disposal. This information is intended to satisfy the requirements of DOE Order 5480.23, paragraph(s) 8.b.(3)(e) and 8.b.(3)(k). ${ }^{1}$ This chapter also includes information that will partially satisfy the requirements of DOE Order 5480.23, paragraph(s) 8.b.(3)(b), (f), and (u). ${ }^{2}$ The scope and format of this chapter is consistent with DOE-STD-3009-94.

The hazard analysis considers a complete spectrum of accidents that may occur during operations at the AHCF. It evaluates potential accident consequences to the public, workers, and the environment and estimates the likelihood of accident occurrence. It identifies and assesses associated preventive and mitigative features and identifies bounding accident scenarios. Further qualitative accident analysis examines the representative and bounding accident scenarios for comparison with evaluation guidelines (Section 3.4.1.3).

The hazards associated with the Auxiliary Hot Cell Facility are analyzed qualitatively. A qualitative analysis is consistent with the simplicity and low hazard potential of the facility and with DOE guidance (DOE 1997a) for Category 3 nuclear facilities. The primary emphasis has been on the hazard screening analysis of all potential accidents. Table 3-1 (p. 3-4) presents the results of the hazard identification. Tables 3-5 and 3-6 (p. 3-14 ff.) qualitatively evaluate the potential for and consequences of the occurrence of the non-industrial hazards identified in Table 3-1. All potential operations and associated accidents of the AHCF are considered.

A more detailed assessment augments and reinforces the consequence estimates of both "representative" and "bounding" accident scenarios. Representative scenarios were selected from those scenarios in Tables 3-5 and 3-6 that have risk rankings of 3 and 4; in general, the most likely scenarios were chosen for analysis. Bounding scenarios have a risk ranking of 2; all bounding scenarios have been analyzed. Scenarios selected for analysis, referred to as the Design Basis Accidents (DBAs), are analyzed in Section 3.4.2.

\footnotetext{
${ }^{1}$ As amplified in Attachment 1, paragraph(s) 4.f.(3)(d)5 and 4.f.(3)(d)11, of the Order (Topics 5 and 11).

${ }^{2}$ As discussed in DOE-STD-3009-94 (DOE 1994a).
} 


\subsection{REQUIREMENTS}

This section identifies the DOE orders and standards that are required to establish the hazard and accident analysis-related safety basis of the AHCF. Each major order, notice, and standard is listed below, and their safety basis requirements are summarized.

- DOE Order 5480.23, Chg. l, "Nuclear Safety Analysis Reports" - Paragraphs 8.b.(3)(e) and 8.b.(3)(k), as amplified in Attachment 1 to the order, paragraphs 4.f.(3)(d)5 and 4.f.(3)(d)11 (Topics 5 and 11), require the analysis of both hazards and the facility classification, along with the assessment of operations, natural phenomena, and external events postulated to occur at the facility (DOE 1994b).

- DOE Order 420.1, "Facility Safety" - Paragraph 4.1.1.1 requires safety analyses to identify the functions of safety class and safety-significant SSCs (DOE 1996b). Analysis is also used to establish the significance of safety functions performed by those SSCs. The safety analyses must consider facility hazards, natural phenomena hazards, and external man-induced hazards. Paragraph 4.4.1 requires safety analyses for hazardous facilities to include the ability of SSCs and personnel to perform their intended safety functions under the effects of natural phenomena.

- DOE-STD-1027-92, Change Notice 1, "Hazard Categorization and Accident Analysis Techniques for Compliance with DOE Order 5480.23, Nuclear Safety Analysis Reports" - This standard provides guidance for determining hazard categorization and performing accident analysis for SARs (DOE 1997a).

- DOE-STD-3009-94, "Preparation Guide for U.S. Department of Energy Nonreactor Nuclear Facility Safety Analysis Reports" - This standard describes an SAR preparation method that is acceptable to the DOE. Chapter 3 of the Standard presents the format and content required for SAR hazard and accident analysis (DOE 1994a).

\subsection{HAZARD ANALYSIS}

This section describes the hazard identification (Section 3.3.1.1) and the Preliminary Hazard Assessment and hazard evaluation (Section 3.3.1.2, Appendix 3-A) performed for the AHCF. It evaluates potential process-related, natural phenomena, and external hazards that could possibly affect the public, workers, colocated workers, and the environment due to single or multiple failures or incidents.

Hazard analysis results are summarized and displayed in Tables 3-5 and 3-6. The final hazard classification for the AHCF is consistent with DOE guidance (DOE 1997a). Issues pertaining to planned design, operational safety, defense in depth, worker safety, and environmental protection are discussed. Finally, representative and bounding hazards are identified for further development in Section 3.4, "Accident Analysis." 


\subsubsection{Methods}

A largely qualitative screening approach consistent with current DOE hazard analysis practices (DOE 1997a; DOE 1994b) and leading industrial hazard evaluation procedures (AIChE 1985) was used to identify and characterize hazards and to perform a systematic evaluation of basic accidents.

The hazard analysis (1) identifies and evaluates potential accidents, (2) identifies representative and bounding accident scenarios that require further development, and (3) verifies the initial hazard classification assigned to the AHCF.

\subsubsection{Hazard Identification}

This section describes the methods used to identify and characterize hazardous materials and energy sources associated with the facilities, operations, and inventory. Source term characteristics are extrapolated primarily from SNL's Local Area Network Materials Accountability System (LANMAS) database, which contains information on current inventories of special nuclear material with no defined use, that is, material potentially available for reuse, recycling, or treatment and disposal as waste. The hazard assessment also considers materials and waste not currently known to exist at SNL, but which can be reasonably expected over the lifetime of the AHCF. The assessment also considers simple treatment, such as acid-base neutralization, sodium treatment, or solidification, possibly required to meet disposal-site waste acceptance criteria.

Hazards associated with each of five work locations are identified (Table 3-1). The five locations considered are the High Bay, the area behind the permanent shield wall (including the temporary room), silos east of the permanent shield wall, the hot cell, and the fume hood.

A preliminary hazard assessment (PHA) is used to initially characterize hazards. PHAs determine mechanisms by which hazardous material can be released and impose harm. PHAs also broadly define prevention and mitigation requirements. They identify hazards and potential accident initiators and document energy sources. The PHA is provided in Appendix 3-A.

An external-event screening assessment is also used to identify hazards to the AHCF. This approach is consistent with the methods recommended by the NRC to screen all conceivable natural and manmade external initiating events. Only those external events that present a plausible threat to the $\mathrm{AHCF}$ are considered further in the hazard evaluation as accident initiators. Appendix 3-D contains a thorough discussion of the method for screening external events and the categorization of each event, including those events dropped from further consideration.

Standard industrial hazards (e.g., handling accidents) are developed in the PHA only to the extent that they initiate or contribute to accidents that could lead to the release of hazardous or radioactive material or to exposure to external ionizing radiation. 
Table 3-1. Hazard Identification

\begin{tabular}{|c|c|c|}
\hline Location & Hazard & Type, Form, Quantity \\
\hline \multirow[t]{6}{*}{ High bay } & Vehicle movement & Forklift, truck. \\
\hline & Kinetic energy & Heavy objects are moved by forklift, truck, or crane. \\
\hline & Electrical hazards & $\begin{array}{l}\text { - All circuits are internal to walls. } \\
\text { - Controls and switches may generate sparks. }\end{array}$ \\
\hline & Thermal source & $\begin{array}{l}\text { - Motors may overheat, or heat may be generated } \\
\text { by vehicular malfunction. } \\
\text { - Exothermic chemical reactions are possible. }\end{array}$ \\
\hline & Chemicals & $\begin{array}{l}\text { - Limited quantities of chemicals exist in the waste } \\
\text { inventory, mostly trace solvents or heavy metal } \\
\text { components; small amounts of uranyl nitrate and } \\
\text { uranium hexafluoride in known wastes. } \\
\text { - No gases in known wastes. } \\
\text { - Quantities of flammable and combustible materials } \\
\text { will be limited. } \\
\text { - Reactive metals are present in some packages. } \\
\text { - Laboratory quantities of standard industrial } \\
\text { chemicals will be used for equipment } \\
\text { maintenance, etc. }\end{array}$ \\
\hline & Radioactive material & $\begin{array}{l}\text { - Highly radioactive material may be present. } \\
\text { - Fissile material will be managed for criticality } \\
\text { through SNL's Criticality Safety Program (Philbin } \\
\text { 1998). }\end{array}$ \\
\hline \multirow[t]{4}{*}{ Fume hood } & Electrical hazards & - Small automated tools and light sources. \\
\hline & Thermal sources & $\begin{array}{l}\text { - Small, heat-generating tools or laboratory } \\
\text { apparatus. }\end{array}$ \\
\hline & Chemicals & $\begin{array}{l}\text { - Limited quantities of chemicals exist in the waste } \\
\text { inventory, mostly trace solvents or heavy metal } \\
\text { components; small amounts of uranyl nitrate and } \\
\text { uranium hexafluoride in known wastes. } \\
\text { - No gases in known wastes. } \\
\text { - Quantities of flammable and combustible materials } \\
\text { will be limited. } \\
\text { - Reactive metals are present in some packages. } \\
\text { - Laboratory quantities of standard industrial } \\
\text { chemicals will be used for equipment } \\
\text { maintenance, etc. }\end{array}$ \\
\hline & Radioactive material & $\begin{array}{l}\text { - Highly radioactive material may be present. } \\
\text { - Most radioactive material in solid form. Some } \\
\text { packages may contain radioactivity in friable } \\
\text { forms. } \\
\text { - Fissile material will be managed for criticality } \\
\text { through SNL's Criticality Safety Program (Philbin } \\
\text { 1998). }\end{array}$ \\
\hline
\end{tabular}


Table 3-1. Hazard Identification (continued)

\begin{tabular}{|c|c|c|}
\hline \multirow{5}{*}{$\begin{array}{l}\text { Area behind the } \\
\text { permanent shield } \\
\text { wall (including the } \\
\text { temporary room) }\end{array}$} & Electrical hazards & Power tools, cutting devices, welding operations. \\
\hline & Thermal sources & Welding and cutting operations. \\
\hline & Chemicals & $\begin{array}{l}\text { - Limited quantities of chemicals exist in the waste } \\
\text { inventory, mostly trace solvents or heavy metal } \\
\text { components; small amounts of uranyl nitrate and } \\
\text { uranium hexafluoride in known wastes. } \\
\text { - Quantities of flammable and combustible materials } \\
\text { will be limited. } \\
\text { - Reactive metals are present in some packages. } \\
\text { - Small, laboratory quantities of chemicals may be } \\
\text { used in waste treatment. }\end{array}$ \\
\hline & Radioactive material & $\begin{array}{l}\text { - Highly radioactive material may be present. } \\
\text { - Some packages may contain radioactivity in } \\
\text { friable forms. } \\
\text { Occasionally, a source will be manipulated behind } \\
\text { the permanent shield wall, with potential for } \\
\text { exposure for personnel intruding outside the } \\
\text { building opposite the wall. } \\
\text { - Fissile material will be managed for criticality } \\
\text { through SNL's Criticality Safety Program (Philbin } \\
\text { 1998). }\end{array}$ \\
\hline & Kinetic energy & Hoist and cranes used to move very heavy objects. \\
\hline \multirow[t]{3}{*}{$\begin{array}{l}\text { Silos east of the } \\
\text { permanent shield } \\
\text { wall }\end{array}$} & Chemicals & $\begin{array}{l}\text { Limited quantities exist in the waste inventory, } \\
\text { mostly trace solvents or heavy metal components; } \\
\text { small amounts of uranyl nitrate and uranium } \\
\text { hexafluoride in known wastes. } \\
\text { Quantities of flammable and combustible materials } \\
\text { will be limited. } \\
\text { Reactive metals are present in some packages. }\end{array}$ \\
\hline & Radioactive material & $\begin{array}{l}\text { - Highly radioactive material may be present. } \\
\text { - Some packages may contain radioactivity in } \\
\text { friable forms. } \\
\text { - Fissile material will be managed for criticality } \\
\text { through SNL's Criticality Safety Program (Philbin } \\
\text { 1998). }\end{array}$ \\
\hline & Kinetic energy & Hoist and cranes used to move very heavy objects. \\
\hline Hot cell & Chemicals & $\begin{array}{l}\text { - Limited quantities of chemicals exist in the waste } \\
\text { inventory, mostly trace solvents or heavy metal } \\
\text { components; small amounts of uranyl nitrate and } \\
\text { uranium hexafluoride in known wastes. } \\
\text { - Quantities of flammable and combustible materials } \\
\text { will be limited. } \\
\text { - Reactive metals are present in some packages. } \\
\text { - Small, laboratory quantities of chemicals may be } \\
\text { used in waste treatment. } \\
\text { - Shield windows contain oil. }\end{array}$ \\
\hline
\end{tabular}


Table 3-1. Hazard Identification (concluded)

\begin{tabular}{|l|l|l|}
\hline & Kinetic Energy & Hoist and cranes used to move very heavy objects. \\
\cline { 2 - 4 } & Thermal source & $\begin{array}{l}\text { - Motors may overheat. } \\
\text { - Exothermic chemical reactions are possible. }\end{array}$ \\
\cline { 2 - 4 } & Electrical hazards & $\begin{array}{l}\text { - All circuits internal to walls. } \\
\text { - Controls and switches may generate sparks. }\end{array}$ \\
\cline { 2 - 4 } & Radioactive material & $\begin{array}{l}\text { Highly radioactive material may be present. } \\
\text { - Some packages may contain radioactivity in } \\
\text { friable forms. }\end{array}$ \\
& $\begin{array}{l}\text { Fissile material will be managed for criticality } \\
\text { through SNL's Criticality Safety Program (Philbin } \\
\text { 1998). }\end{array}$ \\
\hline
\end{tabular}

Hazardous chemicals are expected to be minimal at the AHCF, occurring primarily as minor constituents of the waste. Inventories of hazardous chemicals are controlled by SNL's Integrated Safety Management System (ISMS) process at levels below $25 \%$ of the Process Safety Management (PSM) thresholds specified in 29 CFR 1910.119. These quantities represent the maximum credible amounts that would present themselves at this facility; much lower quantities are actually expected at the AHCF. For the purposes of this analysis, chemicals are evaluated only for the potential impact to the public at $25 \%$ of PSM levels. This is consistent with DOE guidance requiring imposition of 29 CFR 1910.119 requirements when analyses show potential for significant off-site consequences, independent of the type or quantity of chemical involved (DOE 1997a).

Several activities are not addressed in this PSAR:

- Transportation of materials within the boundaries of KAFB,

- Handling of radioactive material above the Hazard Category 2 threshold, and

- Commercial shipment of waste to external disposal facilities.

\subsubsection{Hazard Evaluation}

Hazards are evaluated using the PHA, an accident-scenario-based form of analysis. Hazardous situations (e.g., fire, deflagration) are postulated, and a structured investigation of how such a situation could occur-including other system/facility response issues-follows. The PHA for the AHCF documents potential accident-initiating events, preventive and mitigative features, expected consequences, and safety enhancements (e.g., engineered systems, procedures) required to adequately compensate for the existing hazard.

Hazards are ranked by qualitatively assigning frequency and consequence estimates to each hazard or accident scenario developed in the PHA. Appendix 3-B provides a more 
detailed explanation of how the probabilities were estimated. The results of the PHA serve as the basis for hazard ranking so that representative and bounding accident scenarios can be selected for further development.

Tables 3-2 and 3-3 present the criteria used to rank the hazards by consequence and frequency, respectively. A consequence and frequency is determined for each accident scenario. The combination of consequence and frequency results in a ranking of risk (Table 3-4). All consequence and frequency estimates were based primarily on the consensus engineering judgment of the hazard analysts conducting the PHA. In addition, lessons learned within the DOE Complex (DOE 1996a) and within similar industries (Mahn et al. 1995) were used as input into probability estimates where pertinent (see Appendix 3-B). Consequence estimates were made assuming the failure of all mitigating systems and actions.

$\mathrm{Pu}-239$ at the Category 2 threshold level was used in estimating the consequence of release of radioactive material. (The "Category 2 threshold level" is the minimum inventory that would cause a facility to be a Category 2 nuclear facility. The inventory of a Category 3 nuclear facility is always less than this Category 2 threshold level.) $\mathrm{Pu}-239$ was selected for this analysis as representing a bounding case for release of nonvolatile materials present at the facility at the Category 2 threshold quantity. Minimal quantities of volatiles are expected at the AHCF. The release of a given amount of respirable $\mathrm{Pu}-$ 239 (an alpha emitter) results in a greater effective dose equivalent (EDE) at the exclusion-area boundary than release of the same amount of any of the nonvolatile isotopes of interest (DOE 1997a), except americium-241. However, unlike Am-241, Pu239 is pyrophoric. Therefore, a fire that reaches the ignition temperature of plutonium will release a greater fraction of the metal than will be released in a fire involving a nonpyrophoric material. Furthermore, $\mathrm{Pu}-239$ exhibits a very steep dose-response curve. Because of its high EDE, pyrophoric nature, and steep dose response, the use of Pu-239 results in a conservative, but not unrealistic, estimate. Although less than $0.1 \%$ of the existing waste packages approach Category 2 threshold quantities, packages containing $\mathrm{Pu}-239$ at near-Category-2 threshold levels do exist in the current inventory.

The source term used to estimate risk from external exposures to workers differs from the source term used to estimate risk from airborne radioactive material. For determining the consequences of external radiation exposures to workers, dose estimates assume a $6 \mathrm{kCi}$ source of mixed fission products, more than 120 days post-irradiation. This gammaemitting source would produce a more hazardous external dose to workers than would the $\mathrm{Pu}$ source assumed for the estimates of consequences from an airborne release.

To estimate the potential impact of a toxic chemical release on the public, hydrogen fluoride gas was selected as the test material because of its high toxicity and dispersibility and because HF gas could credibly be handled in the AHCF. The most probable source for HF gas in this facility is uranium hexafluoride, which reacts with water vapor to form uranyl fluoride and hydrogen fluoride gas. Maximum quantities of HF gas allowed in the AHCF would be 60 pounds (25\% of PSM thresholds). The role of chemicals as accident 
Table 3-2. Consequence Severity Categories

\begin{tabular}{|c|c|c|c|c|}
\hline $\begin{array}{c}0 \\
\vdots\end{array}$ & (n) & Affected Pop & ationilEntity & $a^{4}$ \\
\hline Category & Public & Environment & $\begin{array}{l}\text { Colocated } \\
\text { Wórker }\end{array}$ & Worker \\
\hline$A$ & $\begin{array}{l}\text { Immediate } \\
\text { health effects }\end{array}$ & $\begin{array}{l}\text { Significant off-site } \\
\text { contamination } \\
\text { requiring cleanup }\end{array}$ & $\begin{array}{l}\text { Immediate } \\
\text { health effects }\end{array}$ & - Loss of life \\
\hline$B$ & $\begin{array}{l}\text { - Latent health } \\
\text { effects }\end{array}$ & $\begin{array}{l}\text { - Moderate to } \\
\text { significant on-site } \\
\text { contamination } \\
\text { - Moderate off-site } \\
\text { contamination }\end{array}$ & $\begin{array}{l}\text { - Latent health } \\
\text { effects }\end{array}$ & $\begin{array}{l}\text { - Severe injury or } \\
\text { disability }\end{array}$ \\
\hline C & $\begin{array}{l}\text { Irritation or } \\
\text { discomfort but } \\
\text { no permanent } \\
\text { health effects }\end{array}$ & $\begin{array}{l}\text { - Moderate } \\
\text { contamination of } \\
\text { originating facility } \\
\text { - Minor on-site } \\
\text { contamination } \\
\text { - Minor off-site } \\
\text { contamination }\end{array}$ & $\begin{array}{l}\text { Irritation or } \\
\text { discomfort but } \\
\text { no permanent } \\
\text { health effects }\end{array}$ & $\begin{array}{l}\text { - Lost-time injury } \\
\text { but no disability }\end{array}$ \\
\hline$D$ & $\begin{array}{l}\text { - No significant } \\
\text { off-site impacts }\end{array}$ & $\begin{array}{l}\text { - Minor contamina- } \\
\text { tion of originating } \\
\text { facility } \\
\text { - Negligible on-site } \\
\text { contamination } \\
\text { - Negligible off-site } \\
\text { contamination }\end{array}$ & $\begin{array}{l}\text { - No significant } \\
\text { impacts }\end{array}$ & $\begin{array}{l}\text { - Minor or no } \\
\text { impact or } \\
\text { disability }\end{array}$ \\
\hline
\end{tabular}


Table 3-3. Frequency Categories

\begin{tabular}{|c|l|l|l|}
\hline Category & \multicolumn{1}{|c|}{$\begin{array}{c}\text { Characteristic } \\
\text { Word }\end{array}$} & \multicolumn{1}{|c|}{$\begin{array}{c}\text { Frequency } \\
\text { (F) Per Year }\end{array}$} & \multicolumn{1}{|c|}{ Description } \\
\hline I & Normal Operations & $\mathrm{F} \geq 1$ & Normal operations. \\
\hline II & Likely or Anticipated & $1>\mathrm{F} \geq 10^{-2}$ & $\begin{array}{l}\text { Incidents that may occur several times } \\
\text { during the lifetime of the facility, that is, } \\
\text { incidents that commonly occur. }\end{array}$ \\
\hline III & Unlikely & $10^{-2}>\mathrm{F} \geq 10^{-4}$ & $\begin{array}{l}\text { Accidents that are not expected to occur } \\
\text { during the lifetime of the facility. Natural } \\
\text { phenomena of this frequency category } \\
\text { include Uniform Building Code-level } \\
\text { earthquake, 100-year flood, maximum wind } \\
\text { gust, etc. }\end{array}$ \\
\hline V & Very Unlikely & $10^{-4}>\mathrm{F} \geq 10^{-6}$ & $\begin{array}{l}\text { Accidents that will probably not occur during } \\
\text { the life cycle of the facility. This category } \\
\text { includes the design basis accidents. }\end{array}$ \\
\hline & Extremely Unlikely & $10^{-6}>\mathrm{F}$ & $\begin{array}{l}\text { All other accidents. Accidents too unlikely to } \\
\text { be considered in the design basis. Some } \\
\text { accidents in this frequency category may be } \\
\text { evaluated as beyond-design-basis } \\
\text { accidents. }\end{array}$ \\
\hline
\end{tabular}

Table 3-4. Risk Ranking Matrix

\begin{tabular}{|c|c|c|c|c|c|}
\hline $\begin{array}{c}\text { Consequence } \\
\text { Category }\end{array}$ & \multicolumn{5}{|c|}{ Frequency Category } \\
\cline { 2 - 6 } & I & II & III & IV & V \\
\hline A & 1 & 1 & 2 & 2 & 3 \\
\hline B & 1 & 1 & 2 & 3 & 4 \\
\hline C & 2 & 2 & 3 & 3 & 4 \\
\hline D & 3 & 3 & 4 & 4 & 4 \\
\hline
\end{tabular}

Risk Ranking 1: Hazard or accident scenario poses a high risk to the public, colocated workers, workers, or the environment.

Risk Ranking 2: Hazard or accident scenario poses a moderate risk to the public, colocated workers, workers, or the environment.

Risk Ranking 3: Hazard or accident scenario poses a minor risk to the public, colocated workers, workers, or the environment.

Risk Ranking 4: Hazard or accident scenario poses a very minor risk to the public, colocated workers, workers, or the environment. 
initiators has been specifically addressed in Appendixes 3-A and 3-B for flammable and reactive materials.

A risk ranking matrix is used to compare all hazards and accident scenarios identified in the PHA (Table 3-4). The results of the risk ranking serve as the basis for determining whether a more detailed analysis of specified hazards or accident scenarios is required. The definitions and implications of the risk rankings follow:

- Risk Ranking 1: The hazard or accident scenario poses a high risk to the public, colocated workers, workers, or the environment. Immediate actions should be taken by the facility manager to reduce the potential consequences or likelihood of these events. Risk Ranking 1 events are not expected in a Category 3 facility.

- Risk Ranking 2: The hazard or accident scenario poses a moderate risk to the public, colocated workers, workers, or the environment. Near- to moderate-term actions should be taken by the facility manager to reduce the potential consequences or likelihood of these events. All events with a risk ranking of 2 are assessed further in the accident analysis.

- Risk Ranking 3: The hazard or accident scenario poses a minor risk to the public, colocated workers, workers, or the environment. Moderate- to long-term actions should be taken by the facility manager to reduce the potential consequences or likelihood of these events. Selected events with a risk ranking of 3 are discussed in the accident analysis.

- Risk Ranking 4: The hazard or accident scenario poses a very minor risk to the public, colocated workers, workers, or the environment. Long-term actions should be considered by the facility manager to reduce the potential consequences or likelihood of these events. No further analysis is required for Risk Ranking 4 events, although a few such events have been included here.

\subsubsection{Hazard Analysis Results}

The following sections present the results of the hazard analysis. All major hazards are identified and evaluated using qualitative risk criteria; and the final hazard classification for the facility (per DOE 1997a) is presented. Planned design features and operational safety are discussed in light of the hazard analysis. Facility design and administrative features contributing to defense in depth, worker safety, and environmental protection are also discussed.

\subsubsection{Hazard Identification}

Table 3-1 identifies all process-related hazards by hazard type and by types of material at risk. These hazards are the bases of the scenarios presented in the PHA (Appendix 3-A). The external events screening assessment (Appendix 3-D) identifies and categorizes 
external threats to the facility. No identified external events pose a unique hazard, separate from the hazards internal to the AHCF.

The principal hazards associated with the AHCF result from the presence of radioactive materials and wastes, including those with potentially hazardous chemical contaminants. The type and quantity of radionuclides that could be located in the AHCF are defined primarily by radioactive, TRU, and mixed waste that is inappropriate for processing at SNL's Radioactive and Mixed Waste Management Facility, due either to its form or quantity. This material and waste either exceeds Category 3 thresholds for radioactive material or presents a handling hazard from ionizing radiation. The AHCF is designed to characterize, treat (if required), and repackage this material and waste safely for reuse, recycling, or ultimate disposal.

SNL/NM has an existing RCRA Permit for the storage of hazardous waste. SNL/NM has also submitted a Permit Application to the New Mexico Environment Department (NMED) for the storage and treatment of mixed waste. The AHCF will be added to the existing Permit Application for mixed waste, which includes container storage and waste treatment, and the AHCF will also be included in any future permit applications. Storage and treatment at the AHCF is necessary to provide the capability to manage certain types of existing waste; this capability does not currently exist elsewhere at SNL/NM.

The principal hazards for the $\mathrm{AHCF}$ are associated with radioactivity. Administrative controls will be used to limit radioactive materials to less than hazard Category 2 threshold levels (DOE 1997a). Radiological protection procedures (SNL 1999) are used to control and mitigate the radiological hazards to personnel with access to this material. A discussion of how these procedures will be used to ensure worker safety is outside the scope of this PSAR.

The most severe hazard to AHCF personnel is the potential for direct radiation exposure during processing of highly radioactive materials and waste. Extensive radiation shielding has been incorporated into the design of this facility to control the direct radiation dose rate for waste processing operations within the hot cell and behind the permanent shield wall. The shielding is designed to adequately mitigate the radiation dose rate from $6 \mathrm{kCi}$ of mixed fission products, which represents the largest allowable source of ionizing radiation. Colocated workers are subject to the greatest hazard when exposed sources are lifted above the shield wall for insertion into the hot cell. Although in most cases the intact package will be transferred into the hot cell, in some cases, the source must be removed from the package shielding prior to being lifted into the hot cell. The most severe hazard for members of the public is the potential inhalation of radioactive material released as a result of an accident in the AHCF.

Hazardous chemicals are limited in the existing waste to possible trace contaminants and toxic metal components of solid metal parts. A few packages are known to contain gram quantities of uranyl nitrate and uranium hexafluoride, and a greater presence of chemicals over the life cycle of the facility cannot be discounted. The maximum credible hazard can be represented by HF gas at 25\% PSM levels. The potential hazard created by the 
presence of process chemicals, such as acids or bases used for neutralization, is minor compared with the radiological hazard and will be mitigated by remote handling in the hot cell, if appropriate. Any spills will be contained in a spill tray and cleaned up with an acid spill kit.

The potential for deflagration inside the hot cell or within the High Bay, resulting in a release of radiological material, is considered in the PHA. The likelihood and severity of a deflagration is limited by administrative control of the quantity of volatile materials and by the circulation and dilution provided by the ventilation system. The presence of sufficient volatile chemicals to initiate a deflagration is unlikely (see Section 3.4.2.1). If such gases are presented, they would be vented under well-controlled circumstances. Any venting of tritium encountered as a waste component would be done under very controlled circumstances. As long as the ventilation system is operating, an explosive level of flammable vapor is precluded. Administrative controls on inventory will be used to prevent the buildup of an explosive level of flammable vapors.

Processes to be undertaken in the hot cell or temporary room will not be chemically intensive. Most wastes will simply undergo inspection and sorting. Acid-base neutralization and solidification may be required occasionally. Some pressurized containers may require venting. If the waste does not present a significant ionizing radiation hazard, waste may be processed in the walk-in fume hood.

Fissile materials will be managed in the AHCF according to the guidelines provided in SNL's Nuclear Criticality Safety Program (Philbin 1998). Accordingly, criticality safety will be achieved by applying a principle of double contingency, such that at least two unlikely independent and concurrent changes in process conditions must occur before a criticality event is possible. Specific controls will be applied as determined by CSAs to be performed for the facility prior to initiating operations and for specific operations as appropriate. These controls could include a combination of geometry controls, criticality index controls, and administrative controls. Portable criticality monitors may be used as required by the CSA.

\subsubsection{Hazard Classification}

Hazard Category 3 is distinguished by a hazard analysis that shows the "potential for only significant localized consequences" (DOE 1994a). The hazard classification of the AHCF is based primarily on DOE guidance on hazard classification (DOE 1997a). The categorization is based on the assumption of an "unmitigated release" of available hazardous material. In accordance with this guidance, nuclear facilities or facility segments are designated as Hazard Category 2 or 3 if the sum of the ratios of the quantity of each material to the Hazard Category 2 or 3 thresholds exceeds one or if the quantity of fissile isotopes provides the potential for a criticality event (DOE 1997a, Table A.1).

The AHCF has been divided into seven segments for final hazard categorization. The High Bay and hot cell form one segment, and each of six storage silos behind the permanent shield wall forms a separate segment. The storage silos may be segmented from the main facility and from each other because the physical construction of the silos 
isolates them from involvement in accidents in the main facility. The radioactive inventory of each segment will be maintained below Category 2 thresholds. Administrative controls that regulate inventory will be used to ensure that the inventory in the High Bay and hot cell never exceed the Category 2 threshold. In particular, when packages are moved into or out of the silos behind the permanent shield wall, the total High Bay and hot cell inventory, including the package or packages being moved, will not exceed the Category 2 threshold. Other than the limitations imposed by the Category 2 threshold quantities, there are no restrictions on the number of silos that may be open simultaneously.

The south side of the High Bay is used for general storage of miscellaneous items, usually general equipment. Some of these items may be radioactive. Movement of material into this area will be administratively controlled to ensure that the overall inventory of the High Bay and the hot cell is less than Category 2 thresholds.

\subsubsection{Hazard Evaluation}

Each of the hazard and accident scenarios identified in Section 3.3.1.1 (see Table 3-1) is developed further using qualitative evaluation techniques, as appropriate. Based on the PHA, each hazard and accident scenario is qualitatively assigned a consequence and frequency category consistent with Tables 3-2 and 3-3. Consequences were based conservatively on releases or exposures mitigated only by the inherent physical form of the material and passive shielding provided by the facility. Frequencies were estimated according to the logic present in Appendix 3-B, assuming a processing rate of 70 packages per year. For most scenarios, at least an order-of-magnitude increase in the processing rate would be required to change the frequency category. Unless otherwise referenced in Appendix 3-B, all frequency estimates were based primarily on the consensus engineering judgment of the hazard analysts conducting the PHA. Consequences assume unmitigated release of $\mathrm{Pu}-239$ in Category 2 threshold quantities or exposure to a $6 \mathrm{kCi}$ source of mixed fission products, more than 120 days post-irradiation.

From these qualitative assignments, each hazard and accident scenario is also categorized by its risk ranking (Table 3-4). Table 3-5 presents the results of the hazard evaluation for the public and the environment, and Table 3-6 presents the results of the hazard evaluation for workers and colocated workers.

The major findings of the hazard evaluation are as follows:

- Risk to the public or the environment is minor due to the inventory limitations of the Hazard Category 3 classification.

- The highest risk to workers is from direct radiation exposure and is mitigated by the hot-cell construction. The probability of exposure during transfer operations is low given the planned administrative controls. 
- Fire and deflagration are potential hazards, with the major consequence as airborne release of radiological material, because of the confinement by the hot cell. However, few wastes are expected to contain material to support combustion or to initiate deflagration.

\subsection{Planned Design and Operational Safety Improvements}

Design features that enhance safety include the following:

- The hot cell is designed to meet $97 \mathrm{UBC}$, a code upgrade that influences the earthquake design provisions and load factors (Merrick 1998).

- The design of hot cell mechanical and structural components meets all worker safety requirements assuming the bounding limit of a $6.0 \mathrm{kCi}$ source of mixed fission products, more than 120 days post-irradiation, placed adjacent to the interior wall of the hot cell and a worker standing along the exterior wall.

- The ability of the hot cell to meet radiological shielding performance standards will be confirmed prior to commencement of operations.

Table 3-5a. Impact on Public and Environment - Fire in Hot Cell

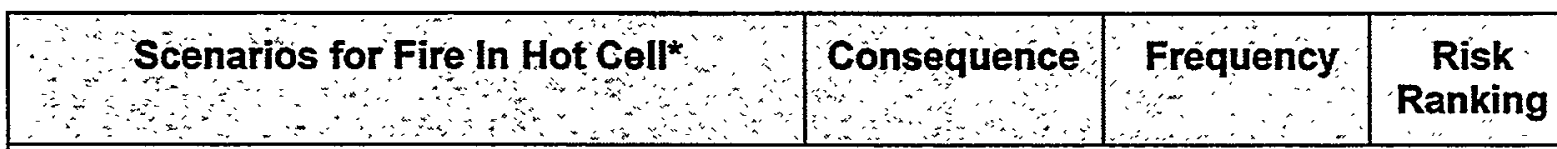

1. Electrical switches or controls spark.

1a. Ignition of flammable materials.

1b. Ignition of waste oil or other combustible materials.

1c. Ignition of window oil - leak or puncture by crane during loading.

1d. Ignition of flammable gas.

\begin{tabular}{|c|c|c|}
\hline D & IV & 4 \\
\hline D & V & 4 \\
\hline D & V & 4 \\
\hline D & III & 4 \\
\hline
\end{tabular}

2. Overheating of exothermic chemical reaction, e.g., acid-base neutralization or solidification.

\begin{tabular}{|l|l|l|l|}
\hline 2a. Ignition of flammable materials. & D & V & 4 \\
\hline 2b. Ignition of waste oil. & D & V & 4 \\
\hline 2c. Ignition of flammable gas. & D & IV & 4 \\
\hline 3. Autoignition of reactive metals. & D & III & 4 \\
\hline 4. External event - Earthquake. & D & IV & 4 \\
\hline 4a. Ignition of natural gas. & D & IV & 4 \\
\hline 4b. Ignition of flammable materials. & D & IV & 4 \\
\hline 5. Aircraft crash with fuel ignition. &
\end{tabular}

* Assumes a fire that ignites Pu and involves the total inventory. Centerline EDE would be about 0.005 rem at $3000 \mathrm{~m}$. 
Table 3-5b. Impact on Public and Environment - Fire Outside Hot Cell

\begin{tabular}{|l|l|l|l|}
\hline Scenarios for Fire Outside Hot Cell* & Consequence & Frequency & Risk \\
& Ranking \\
\hline
\end{tabular}

1. Electrical switches or controls spark.

1a. Ignition of a large spill of flammable materials. 1a1. Major package mishandling. 1a2. Package leak.

\begin{tabular}{|l|l|l|}
\hline D & IV & 4 \\
\hline$D$ & V & 4 \\
\hline
\end{tabular}

2. Forklift moves package.

2a. Ignition from equipment malfunction, such as catastrophic battery failure or the leaking of hydraulic/brake fluid onto hot brake surfaces.

3. External event - Earthquake.

3a. Ignition of natural gas.

3b. Ignition of flammable materials.

4. Aircraft crash with fuel ignition.

$\mathrm{D}$

III

4

* Assumes a fire that ignites Pu and involves the total inventory. Centerline EDE would be 0.005 rem at $3000 \mathrm{~m}$.

Table 3-5c. Impact on Public and Environment - Deflagration Inside Hot Cell

\begin{tabular}{|c|c|c|c|}
\hline $\begin{array}{l}\text { Scenarios for Deflagration Inside Hot } \\
\text { Céll* }\end{array}$ & $\begin{array}{l}\text { Cónsequence } \\
\because\end{array}$ & Frequency & $\begin{array}{l}\text { Risk } \\
\text { Ranking }\end{array}$ \\
\hline \multicolumn{4}{|l|}{ 1. Electrical switches or controls spark. } \\
\hline $\begin{array}{l}\text { 1a Deflagration of vapors from flammable } \\
\text { materials. }\end{array}$ & $\mathrm{D}$ & III & 4 \\
\hline 1b. Ignition of flammable gas. & $\mathrm{D}$ & III & 4 \\
\hline $\begin{array}{l}\text { 2. Deflagration of hydrogen generated by } \\
\text { acid-base neutralization. }\end{array}$ & $\mathrm{D}$ & IV & 4 \\
\hline \multicolumn{4}{|l|}{ 3. External event - Earthquake. } \\
\hline 3a. Crane or building collapses hot cell. & $\mathrm{D}$ & IV & 4 \\
\hline 4. Aircraft crash with fuel ignition. & $\mathrm{D}$ & IV & 4 \\
\hline
\end{tabular}

* Assumes release of Pu particulates. EDE of 0.04 rem at $3000 \mathrm{~m}$. 
Table 3-5d. Impact on Public and Environment - Deflagration Outside Hot Cell

\begin{tabular}{|c|c|c|c|}
\hline Scenarios for Deflagration Outside Hot & Consequence* & Frequency & $\begin{array}{l}\text { Risk } \\
\text { Ranking }\end{array}$ \\
\hline \multicolumn{4}{|l|}{ 1. Electrical switches or controls spark. } \\
\hline $\begin{array}{l}\text { 1a. Deflagration of vapors from flammable } \\
\text { materials. }\end{array}$ & $\mathrm{C}$ & IV & 3 \\
\hline 1b. Ignition of flammable gas. & $\mathrm{C}$ & IV & 3 \\
\hline \multicolumn{4}{|l|}{ 2. External event - Earthquake. } \\
\hline 2a. Deflagration of flammable vapors. & $\mathrm{C}$ & IV & 3 \\
\hline 2b. Deflagration of natural gas. & $\mathrm{C}$ & IV & 3 \\
\hline 3. Aircraft crash with fuel ignition. & $\mathrm{C}$ & IV & 3 \\
\hline
\end{tabular}

Assumes release of Pu particulates. EDE of $0.04 \mathrm{rem}$ at $3000 \mathrm{~m}$.

*Consequence dominated by impacts on the environment; no impacts on the public are expected.

Table 3-5e. Impact on Public and Environment - Radioactive Contamination Outside Hot Cell

\begin{tabular}{|c|c|c|c|}
\hline $\begin{array}{l}\text { Scenarios for Radioactive } \\
\text { Contamination Outside Hot Cell }\end{array}$ & Consequéncé & Frequency & $\begin{array}{l}\text { Risk } \\
\text { Rạnking }\end{array}$ \\
\hline $\begin{array}{l}\text { 1. Package dropped or spilled by crane or } \\
\text { forklift. }\end{array}$ & $\mathrm{D}$ & III & 4 \\
\hline $\begin{array}{l}\text { 2. Package surface contaminated } \\
\text { (inadequate surveillance). }\end{array}$ & $\mathrm{D}$ & "II & 3 \\
\hline $\begin{array}{l}\text { 3. Fire protection water contaminates } \\
\text { building. }\end{array}$ & $\mathrm{D}$ & III & 4 \\
\hline 4. Drum HEPA filter improperly secured. & $\mathrm{D}$ & II & 3 \\
\hline 5. Package dropped down storage holes. & $\mathrm{D}$ & III & 4 \\
\hline 6. External event - Earthquake. & $\mathrm{D}$ & III & 4 \\
\hline 7. Aircraft crash with fuel ignition. & $\mathrm{D}$ & IV & 4 \\
\hline
\end{tabular}


Table 3-6a. Impact on Colocated Worker or Facility - Fire in Hot Cell

\begin{tabular}{|c|c|c|c|}
\hline Scenarios for Fire In Hot Cell & Consequence & Frequency & $\begin{array}{l}\text { Risk } \\
\text { Ranking }\end{array}$ \\
\hline \multicolumn{4}{|l|}{ 1. Electrical switches or controls spark. } \\
\hline 1a. Ignition of flammable materials. & $\mathrm{C}$ & IV & 3 \\
\hline $\begin{array}{l}\text { 1b. Ignition of waste oil or other } \\
\text { combustible materials. }\end{array}$ & $\mathrm{C}$ & $\mathrm{V}$ & 4 \\
\hline $\begin{array}{l}\text { 1c. Ignition of window oil- leak or } \\
\text { puncture by crane during loading. }\end{array}$ & C & $\mathrm{V}$ & 4 \\
\hline 1d. Ignition of flammable gas. & $\mathrm{C}$ & IIII & 3 \\
\hline \multicolumn{4}{|c|}{$\begin{array}{l}\text { 2. Overheating of exothermic chemical reaction, e.g., acid-base neutralization or } \\
\text { solidification. }\end{array}$} \\
\hline 2a. Ignition of flammable materials. & $\mathrm{C}$ & $\mathrm{V}$ & 4 \\
\hline 2b. Ignition of waste oil. & C & $\mathrm{V}$ & 4 \\
\hline 2c. Ignition of flammable gas. & $\mathrm{C}$ & IV & 3 \\
\hline 3. Autoignition of reactive metals. & C & III & 3 \\
\hline \multicolumn{4}{|l|}{ 4. External event - Earthquake. } \\
\hline 4a. Ignition of natural gas. & $\mathrm{C}$ & IV & 3 \\
\hline 4b. Ignition of flammable materials. & $\mathrm{C}$ & IV & 3 \\
\hline 5. Aircraft crash with fuel ignition. & $\mathrm{C}$ & IV & 3 \\
\hline
\end{tabular}

${ }^{*}$ Assumes a fire that ignites Pu and involves the total inventory.

** Consequence dominated by contamination; no acute health impacts on workers are expected.

Table 3-6b. Impact on Colocated Worker or Facility - Fire Outside Hot Cell

\begin{tabular}{|l|l|l|l}
\hline Scenarios for Fire Outside Hot Cell & Consequence ${ }^{\star *}$ & Frequency & Risk \\
Ranking
\end{tabular}

1. Electrical switches or controls spark.

1a. Ignition of a large spill of flammable materials.

1a1. Major package mishandling.

1a2. Package leak.

2. Fork lift moves package.

2a. Ignition from equipment malfunction, such as catastrophic battery failure or the leaking of hydraulic/brake fluid onto hot brake surfaces.

3. External event - Earthquake.

3a. Ignition of natural gas.

3b. Ignition of flammable material.

4. Aircraft crash with fuel ignition.

* Assumes a fire that ignites Pu and involves the total inventory.

\begin{tabular}{|c|c|c|}
\hline C & IV & 3 \\
\hline C & V & 4 \\
\hline C & IV & 3 \\
\hline
\end{tabular}

**. Consequence dominated by contamination; no acute health impacts on workers are expected. 
Table 3-6c. Impact on Colocated Worker or Facility - Deflagration Inside Hot Cell

\begin{tabular}{|l|l|l|l|l}
\hline Scenariós for Deflagration Inside Hot & Consequence & Frequency & Risk \\
Rell & Ranking \\
\hline
\end{tabular}

1. Electrical switches or controls spark.

\begin{tabular}{|l|l|l|l|}
\hline $\begin{array}{l}\text { 1a. Deflagration of vapors from } \\
\text { flammable materials. }\end{array}$ & B & III & 2 \\
\hline 1b. Deflagration of flammable gas. & B & III & 2 \\
\hline $\begin{array}{l}\text { 2. Deflagration of hydrogen generated } \\
\text { by acid-base neutralization. }\end{array}$ & B & IV & 3 \\
\hline
\end{tabular}

3. External event - Earthquake.

\begin{tabular}{|l|l|l|l|}
\hline 3a. Crane or building collapses hot cell. & B & IV & 3 \\
\hline 4. Aircraft crash with fuel ignition. & B & IV & 3 \\
\hline
\end{tabular}

* Assumes release of Pu particulates.

**Consequence dominated by contamination; no acute health impacts on workers are expected.

Table 3-6d. Impact on Colocated Worker or Facility — Deflagration Outside Hot Cell

\begin{tabular}{|c|c|c|c|}
\hline $\begin{array}{l}\text { Scenarios for Deflagration Outside } \\
\text { Hot Cêl* }\end{array}$ & Consequence & Frequency & $\begin{array}{l}\text { Risk. } \\
\text { Ranking }\end{array}$ \\
\hline \multicolumn{4}{|l|}{ 1. Electrical switches or controls spark. } \\
\hline $\begin{array}{l}\text { 1a. Deflagration of vapors from } \\
\text { flammable materials. }\end{array}$ & B & IV & 3 \\
\hline 1b. Deflagration of flammable gas. & B & IV & 3 \\
\hline \multicolumn{4}{|l|}{ 2. External event - Earthquake. } \\
\hline 2a. Deflagration of natural gas. & $\mathrm{B}$ & IV & 3 \\
\hline 2b. Deflagration of flammable vapors. & $B$ & IV & 3 \\
\hline 3. Aircraft crash with fuel ignition. & B & IV & 3 \\
\hline
\end{tabular}

${ }^{*}$ Assumes release of Pu particulates.

**Consequence dominated by contamination; no acute health impacts on workers from release of radioactive material are expected. 
Table 3-6e. Impact on Worker, Colocated Worker or Facility - Radioactive Contamination Outside Hot Cell

\begin{tabular}{|c|c|c|c|}
\hline $\begin{array}{l}\text { Scenarios for Radioactive } \\
\text { Contamination Outside Hot Cell }\end{array}$ & $\begin{array}{l}\text { Consequence } \\
\end{array}$ & $\begin{array}{l}\text { Frequency } \\
\text {. }\end{array}$ & $\begin{array}{l}\text { Risk } \\
\text { Ranking }\end{array}$ \\
\hline $\begin{array}{l}\text { 1. Package dropped or spilled by crane or } \\
\text { forklift. }\end{array}$ & $\mathrm{D}$ & III & 4 \\
\hline $\begin{array}{l}\text { 2. Package surface contaminated } \\
\text { (inadequate surveillance). }\end{array}$ & $\mathrm{D}$ & II & 3 \\
\hline $\begin{array}{l}\text { 3. Fire protection water contaminates } \\
\text { building. }\end{array}$ & $\mathrm{C}$ & III & 3 \\
\hline 4. Package HEPA filter improperly secured. & $\mathrm{D}$ & II & 3 \\
\hline 5. Package dropped down storage holes. & C & III & 3 \\
\hline 6. External event - Earthquake. & $\mathrm{C}$ & III & 3 \\
\hline 7. Aircraft crash with fuel ignition. & $\mathrm{C}$ & IV & 3 \\
\hline
\end{tabular}

Table 3-6f. Impact on Worker, Colocated Worker or Facility - Worker Exposure

\begin{tabular}{|l|c|c|c|}
\hline \multicolumn{1}{|c|}{ Scenarios for Worker Exposure } & Consequence & Frequency & $\begin{array}{c}\text { Risk } \\
\text { Ranking }\end{array}$ \\
\hline 1. Failure of passive radiation shielding. & C & III & 3 \\
\hline $\begin{array}{l}\text { 2. Package surface contaminated } \\
\text { (inadequate surveillance). }\end{array}$ & D & II & 3 \\
\hline
\end{tabular}

3. Exposed source above permanent shield wall.

3a. Colocated worker breaches controlled space outside building normal operation. ${ }^{*}$

3b. Power failure.

4. Source exposed by mishandling. ${ }^{\star \star}$

* Maximum exposure of $13.3 \mathrm{rem} / \mathrm{hr}$ for $6 \mathrm{kCi}$ source.

**The largest possible exposed source is $6 \mathrm{kCi}$ mixed fission products, more than 120 days post-irradiation. 
- For normal operations, a HEPA filter system will prevent uncontrolled releases of radioactive material to the environment.

- RAMs will be placed external to the hot cell.

- The High Bay will be equipped with an automatic sprinkler system.

- The hot cell will allow insertion of clean-agent (nonaqueous) fire suppressant by a manual quick-connect between the clean-agent supply and a dispensing wand and nozzle inside the hot cell. Administrative controls will ensure that the clean agent is always available.

- A port will allow the deluge of the entire hot cell with water if deemed necessary by fire-fighting personnel.

Several planned operational features at the AHCF that influence the probability and consequence of accidents include some combination of the following:

- Administrative controls will limit amounts of flammable materials allowed in the hot cell.

- To prevent contamination, surveillance of package surfaces will be performed as appropriate to comply with the RPPM (SNL 1999), and procedures to prevent cross-contamination of containers will be developed.

- To enhance safety of transfer operations, a combination of a temporary generator providing backup power to the chain hoist and guide wires manipulated manually will allow loads suspended by the crane to be placed in a safe configuration, should power fail during transfer operations. Backup power will be required only during transfer of exposed sources that present a significant radiation hazard, as defined by the RPPM (SNL 1999).

- A chain hoist in series with the bridge crane and suspended from the bridge crane will be used to lower loads into the hot cell, preventing contamination of the crane.

- Sodium handling will require constant surveillance and accessible material for manual fire suppression.

- RAM monitors will warn of the presence of ionizing radiation. They must be routinely calibrated and must be functioning during operations.

- Radiation safety will be enhanced by self-alarming personal dosimeters, where appropriate. 


\subsection{Defense in Depth}

There are no safety class SSCs in the AHCF. The criteria used to identify mitigation features as major contributors to defense in depth or to prevent serious worker injury or death (DOE 1994b) are illustrated in Figure 3-1. Safety SSCs that provide mitigative or preventive functions are divided into two categories: (1) safety-class and (2) safetysignificant. Safety-class SSCs (SCSSCs) are those SSCs, including environmental monitors and portions of process systems, whose failure could adversely affect the environment or safety and health of the public as identified by safety analysis. The phrase "adversely affect" refers to exceeding off-site evaluation guidelines (i.e., a wholebody dose of $25 \mathrm{rem}$ to the nearest located member of the public). SCSSCs are systems, structures, or components whose preventive or mitigative function is necessary to keep hazardous material exposure to the public below the evaluation guidelines.

Safety-significant SSCs (SSSSCs) are those whose preventive or mitigative function is a major contributor to defense in depth (i.e., prevents an uncontrolled hazardous material release) and/or worker safety as determined from hazard analysis. SSSSC designations based on worker safety are limited to those systems, structures, or components whose failure is estimated to result in an acute worker fatality or serious injuries to workers. Serious injuries, as used here, are those injuries requiring medical treatment for immediately life-threatening or permanently disabling injuries (e.g., loss of eye or limb) from other than standard industrial hazards. It specifically excludes potential latent effects (e.g., potential carcinogenic effects of radiological exposure or uptake).

The philosophy of defense in depth has shaped the design of the AHCF. The primary safety feature is passive, provided by the hot cell itself. Entry is from top portals, eliminating the possibility of radiation or contaminant leaks around door joints. Ventilation will maintain a negative pressure differential with respect to that portion of the AHCF outside the hot cell and will provide an airflow through the hot cell of $700 \mathrm{acfm}$.

Radioactive material in particulate form may become suspended within either the hot cell or the fume hood. Air from both the hot cell and the fume hood will pass through HEPA filters to prevent release of airborne contaminants to the environment.

No significant releases are expected during normal operation of the facility; however, abnormal and accident events during waste manipulation could release hazardous material inside the hot cell. These events include fire, deflagration, and undetected contamination of the external surface of containers. Administrative controls on the quantities of flammable or volatile material within the hot cell will be limited to levels recommended by 'UBC Table 3-D (ICBO 1997) for unsprinkled areas. Mitigation is through a manually operated fire suppression system in the hot cell and a sprinkler system in the main facility. 


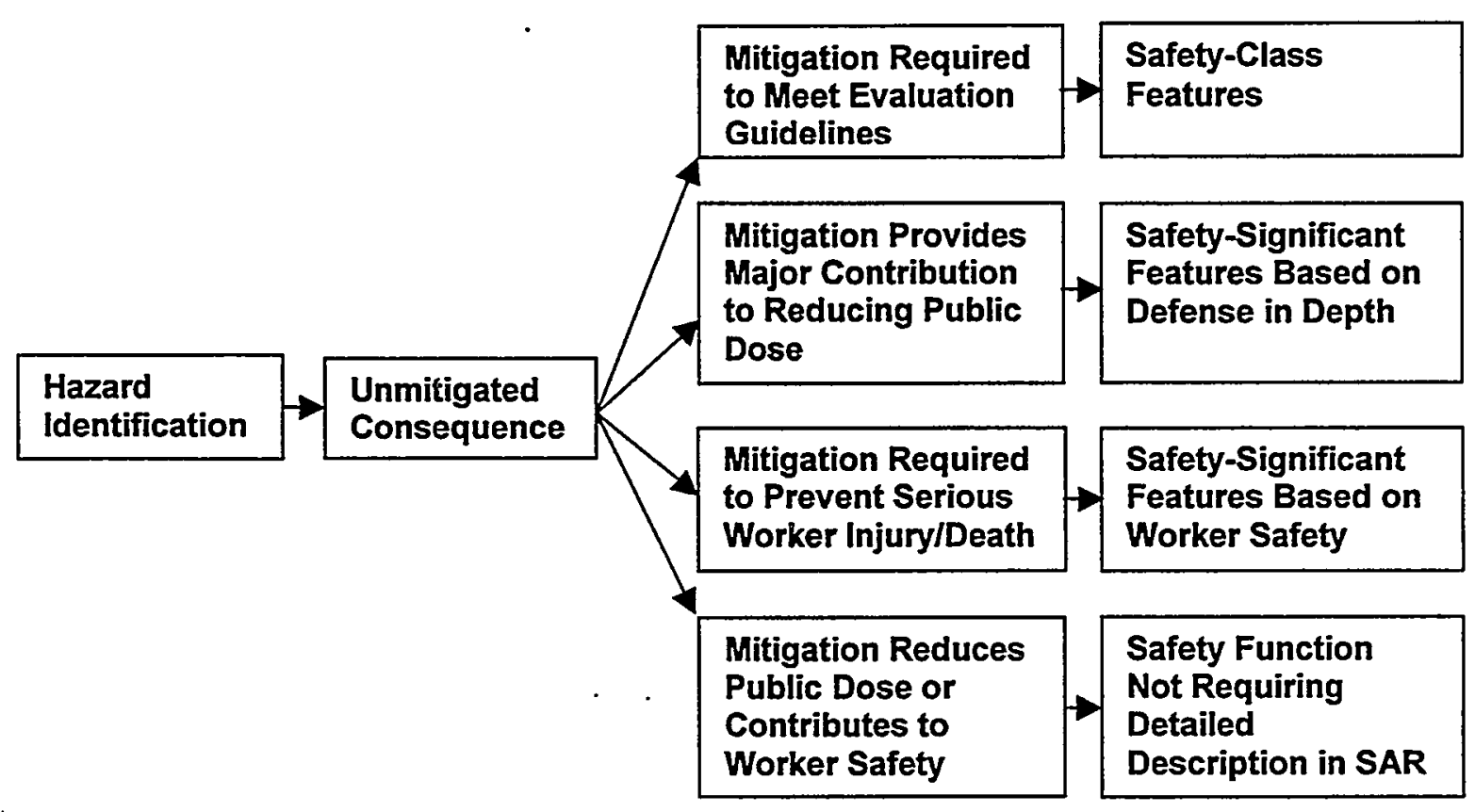

Figure 3-1. Hazard Evaluation Process: Identification of Safety Functions and Safety-Related SSCs.

In summary, the following defense-in-depth features exist in the AHCF:

- Physical features:

- Negative pressure differential maintained within the hot cell when roof plugs are in place;

- Adequate air flow in the fume hood, temporary room, and hot cell when the roof plugs are off;

- Radiation shielding provided by the hot cell, permanent shield wall, and silo shield plugs; and

- HEPA filtering of environmental effluent.

- Administrative features:

- Administrative limitations on flammable or volatile materials in the hot cell;

- Administrative limitations on radioactive inventory; and

- Administrative controls that forbid parking the crane above the hot cell when not in use. 
The role of each of these features in performing a safety function is determined in the accident evaluation. The primary safety function of the facility is the passive barrier to ionizing radiation provided by the hot cell.

\section{Safety-Significant SSCs}

The AHCF does not present a risk to the public. However, two features contribute to protection of the worker and prevent the spread of contamination to the environment:

- HEPA filters: To the extent that the HEPA filters are needed to prevent inadvertent releases of particulates to the environment, these filters must be in place and functioning. Filters will be replaced periodically.

- Ventilation system: The hot cell is not airtight, and the ventilation system must maintain a negative pressure differential with respect to the High Bay. The ventilation system will be monitored by measuring airflow from Zone 2 to Zone 1 and a pressure differential across the HEPA filters, as appropriate (see Section 2.5.5).

\section{TSRs}

Each of the safety-significant SSCs mentioned above will require technical safety requirement (TSR) coverage to ascertain their integrity prior to and during operations of the AHCF. The scope of the TSR coverage will be determined by the degree to which the barriers of the facility safety basis are seriously challenged.

\subsection{Worker Safety}

Safety-significant SSC designations based on worker safety are limited to those systems, structures, and components whose failure is estimated to result in an acute worker fatality or serious injury to workers (DOE.1994b). The following AHCF SSCs are designated safety-significant SSCs.

- Hot cell structure: The shield walls of the hot cell are designated safety significant for worker protection from direct radiation.

- Permanent shield wall: The permanent shield wall is designated safety significant for worker protection from direct radiation.

- Shield plugs: The shield plugs installed at the top of each storage silo where radioactive material is stored behind the permanent shield wall are designated safety significant for worker protection from direct radiation. (The silo itself, separate from the shield plug, does not protect from safety-significant hazards. Silos and shield plugs will be designed in accordance with SNL's RPPM and ALARA principles.) 
Programmatic elements that contribute to worker safety are listed below:

- Fire Protection Program,

- Radiation Protection Program,

- Criticality Safety Program,

- Emergency Preparedness Program,

- Conduct of Operations Program,

- Quality Assurance Program,

- Qualification and Training Program,

- Maintenance,

- Configuration Management, and

- Integrated Safety Management Program.

\subsection{Environmental Protection}

The design and operation of the AHCF minimize the potential for significant radiological releases to the environment. Minimum gaseous or volatile releases are expected. Particulate effluents will be filtered through a HEPA filter if released in either the hot cell or the fume hood. Airflow from Zone 2 to Zone 1 ensures that the hot cell air is filtered through the HEPA filters. Fire-protection water released inside the building will be retained within a trenching system. Contaminated water would not be released into the environment.

\subsection{Accident Selection}

Based on a review of the hazard tables prepared for this analysis (Tables 3.5 and 3.6), the following accidents were identified as DBAs for more detailed qualitative evaluation in this analysis:

- Fire inside hot cell-ignition of flammable materials (representative),

- Fire inside hot cell-autoignition of reactive metals (representative),

- Fire outside hot cell-vehicular equipment malfunction (representative),

- Fire outside hot cell; external event—earthquake (bounding),

- Deflagration inside hot cell-ignition of flammable gas (bounding),

- External exposure to worker - failure of passive radiation shielding (bounding),

- External exposure to worker-exposed source above the permanent shield wall (representative), and

- Chemical release from the AHCF (bounding).

The consequences of accidents involving any one of the silos east of the permanent shield wall are bounded by these accidents in the High Bay or hot cell. These DBAs include those postulated events that pose the greatest risk and therefore bound the AHCF operational risk. Representatives of various types of events identified in the hazard tables were also selected, even if the risk was evaluated to be low. 
Criticality has been excluded from the DBAs for several reasons. Criticality safety is ensured through SNL's Criticality Safety Program, as described in Chapter 6 of the FSAR. The Criticality Safety Program requires the imposition of the double contingency principle. The use of the administrative controls and physical constraints (e.g., mass limits and geometry constraints) imposed by this program has been determined to make a criticality accident incredible. In addition, a Criticality Safety Assessment will be performed for the ACHF as a whole prior to initial operations, and package-specific CSAs will be performed as appropriate.

\subsection{ACCIDENT ANALYSIS}

This section develops the potential accidents identified in Section 3.3.2.3.5, "Accident Selection."

\subsubsection{Methods}

This section summarizes the methods used to evaluate and quantify the consequences of operational accidents, natural phenomena events, and external events selected in Section 3.3.2.3.5 as DBAs. Only airborne releases of radioactive material produce consequences to the public and the environment; no liquid or solid radioactive material would be released in the selected accidents. The airborne pathway is of primary interest for releases from nonreactor nuclear facilities (DOE 1997a). External exposure to direct or scattered radiation is a hazard only for workers. Members of the public are too far away to be exposed to direct or scattered radiation from the sources in the AHCF. The consequence of a chemical release is also evaluated in terms of the effect on the public.

The methods used to estimate the consequences of the DBAs fall into two general categories: (1) methods to determine the radioactive or other hazardous material source terms; and (2) methods to estimate the dose resulting from release of the source term.

\subsubsection{Source Term Estimation}

This section describes the method used to estimate source terms for both radioactive and chemical releases.

\subsection{Radioactive Source Term Estimation}

The potential radioactive source terms are very diverse due to the nature of the waste stream from research and development activities and the variety of materials available for recycling or reuse. The radioactive isotope inventory will be administratively controlled below the threshold quantities for a Category 2 nuclear facility. Therefore, the consequence of release of radioactive material is conservatively bounded by the use of the maximum potential quantities of plutonium-239, if the concern is internally deposited radioactive material, or by $6 \mathrm{kCi}$ of mixed fission product, if the concern is worker exposure to ionizing radiation. $\mathrm{Pu}-239$ is selected for this analysis as representing a bounding case for release of nonvolatile materials present at the facility at the Category 2 threshold quantity. Volatile radionuclides are not expected. 
The results of calculations using this method for airborne releases for various types of accidents are given in Table 3-7. The doses from a maximum credible accidental release given several generic release conditions from this facility are very low at the exclusionarea boundary. By definition, this result is to be expected from a Category 3 nuclear facility because of the limited permissible inventories. Four factors make the dose estimates in Table 3-7 extremely conservative:

- Sandia's Pu inventory is primarily in oxide form and thus not pyrophoric;

- Less than $1 \%$ of the packages in inventory approach the Category 2 threshold quantities;

- The dose estimates take no credit for plate out or HEPA filtration; and

- A fire that burns long enough and hot enough to reach the autoignition temperature for $\mathrm{Pu}$ is unlikely because of the lack of combustible and flammable materials in the vicinity of the waste.

Depending on the accident, the source term inventories released by failure of the hot-cell confinement barrier may be reduced during transport or leakage from the facility to the environment. For example, particulates may be retained by the HEPA filter system. For the purposes of this analysis, however, no reduction of release is assumed.

The final airborne source term released from the AHCF to the environment is calculated as follows (DOE 1994c):

Release Source Term $=$ MAR $\times$ DR $\times$ ARF $\times$ RF $\times$ LPF

where:

MAR = Material at risk (curies or grams),

$\mathrm{DR}$ = Damage ratio (fraction of MAR affected),

$\mathrm{ARF}=$ Airborne release fraction (i.e., fraction of MAR $\times \mathrm{DR}$ that becomes airborne),

$\mathrm{RF}=$ Respirable fraction (i.e., the fraction of airborne particles that are small enough to enter the respiratory system of the body), and

LPF = Leak-path factor (fraction released after plate out, filtering, etc.).

For the purposes of this analysis, the MAR was the threshold for Pu-239 for Hazard Category 2 facilities, or $56 \mathrm{Ci}$ of plutonium-239. Few waste packages are actually expected to contain an inventory with this hazard potential, so the analysis represents the maximum possible consequences given the Category 3 classification.

DR and LPF were both set at 1.0. 
Table 3-7. Dose Estimates for Release of Pu-239 from the AHCF. Material at risk (MAR) $=56 \mathrm{Ci}$ of Pu-239 (Category 2 threshold quantities). Doses assume 24-hour exposure.

\begin{tabular}{|c|c|c|c|c|}
\hline Scenario & $\begin{array}{l}\text { Airborne } \\
\text { Release } \\
\text { Fraction* }\end{array}$ & $\begin{array}{l}\text { Respirable } \\
\text { Fraction }\end{array}$ & $\begin{array}{l}\text { Respirable } \\
\text { Curries } \\
\text { Released }\end{array}$ & $\begin{array}{l}\text { Median } \\
\text { EDE } \\
\text { (rems), } \\
2900 \text { to } \\
3000 \mathrm{~m}\end{array}$ \\
\hline $\begin{array}{l}\text { Fire - less than self- } \\
\text { sustained oxidation. }\end{array}$ & $3 \times 10^{-5}$ & .04 & .000067 & .00002 \\
\hline $\begin{array}{l}\text { Fire - exceeds self- } \\
\text { sustained oxidation. }\end{array}$ & $5 \times 10^{-4}$ & .5 & .014 & .005 \\
\hline $\begin{array}{l}\text { Deflagration with } \\
\text { mechanical } \\
\text { dispersion of } \\
\text { particulates }\end{array}$ & $5 \times 10^{-3}$ & .4 & .112 & .04 \\
\hline
\end{tabular}

*(DOE 1994c).

DOE (1994c) recommended values of the other factors for a wide range of accident release situations, based on tests and accident data. The DOE values will be used in the accident analysis presented in the SAR for the AHCF.

For example, for deflagration the release source term is:

56 curies (MAR) $\times 1.0(\mathrm{DR}) \times 5 \times 10^{-3}(\mathrm{ARF}) \times 0.4(\mathrm{RF}) \times 1.0(\mathrm{LPF})=.112$

\subsection{Chemical Source Term Estimation}

As discussed in Section 3.3.1.1, the source term for the chemical release evaluation was assumed to be $25 \%$ of the threshold quantities of HF gas in 29 CFR 1910.119. This quantity is $27 \mathrm{~kg}(60 \mathrm{lbs})$. The chemical inventories actually appearing in the AHCF are expected to be considerably lower. Hydrogen fluoride gas was selected as the indicator chemical for this analysis. For the chemical release, all factors in Eq. 3-1, except for the MAR, are 1.0.

\subsubsection{Dose Consequence Evaluation}

This section discusses doses arising from the release of both radioactive and chemical sources. 


\subsection{Radioactive Dose Consequence Evaluation}

Estimates of dose resulting from release of the radioactive source term are based on a database of airborne dose vs. distance calculations for single-isotope releases from TA-V facilities (Naegeli 1999). The database was developed using MACCS2 (Chanin and Young 1997) computer model, with a standard input for each single-isotope calculation.

MACCS2 had its origin in the CRAC code developed by SNL for the NRC to calculate the health and economic consequences of accidental releases of radioactive material to the atmosphere for the Reactor Safety Study (NRC 1975). MACCS, the immediate predecessor of MACCS2, has been distributed by government code centers since 1990 . Originally developed to evaluate the effects of severe accidents at nuclear power plants on the surrounding public, it has been widely used in studies assessing the safety of other types of DOE facilities. It has occasionally been used to assess DOD nuclear facilities. DOE commissioned the MACCS2 revision for safety analyses at its facilities. MACCS2 includes dose conversion factors for a much larger set of radionuclides developed by the U.S. Environmental Protection Agency (EPA) in Federal Guidance Report 11 and 12 (Eckerman et al. 1989, Eckerman and Ryman 1993). MACCS and MACCS2 have been used repeatedly for safety analysis reports for other SNL nuclear facilities.

MACCS2 calculates atmospheric transport, dispersion, deposition, and dose for the released inventory. A Gaussian dispersion model based on the Tador-Gur parameterization is used here for consistency with safety studies on other TA-V facilities. Several dose pathways were modeled: radioactive plume inhalation and immersion, ground shine from deposited radiation, and resuspension inhalation dose. Ground shine and resuspension inhalation pathways are minor contributors to dose.

The MACCS 2 code modeled weather for transport and dispersion by sampling a database of 8760 hourly weather data covering one full year. The Typical Meteorological Year for the Albuquerque International Airport (Sunport) was chosen as representative site weather data (Aldrich et al. 1982). This weather file has been used for CRAC and MACCS dose vs. distance calculations in TA-V SARs since 1980 . The weather data were sampled using a weather bin random-sampling scheme, which sorted the singlehour weather data by wind speed, stability class, and precipitation. The same numbers of single-hour weather samples were taken from each weather bin by random sampling. Each single-hour weather sample defined the start time for a 120-hour weather data case that was used for dose calculation. The same weather cases were used for a dose vs. distance calculation for each isotope.

The resulting weather bin sampling doses were highest close to TA-V and decreased with distance. Doses at the 3000-m range and beyond are comparable to doses for weather cases chosen randomly from the whole 8760 hourly weather cases.

The model for dose quantification was the 95th quantile of dose for straight-line dispersion modeling. ${ }^{3}$ This model of dispersion combines the calculated dose at a distance with

\footnotetext{
${ }^{3}$ A quantile is a logarithmic interpolation of the frequency listing.
} 
the yearly wind rose distribution of wind frequency for sixteen compass directions to obtain sixteen doses with attendant frequencies for each weather case sampled. The MACCS2 code then tabulates increasing dose vs. cumulative frequency. It calculates the 95th quantile dose by interpolating between increasing dose values near $95 \%$ of the total frequency. The resulting single dose at each distance for an isotope is characteristic of all wind directions and the typical range of site weather conditions. The 95th quantile dose is a conservative estimate of the worst case dose and is consistent with NRC guidance for assessing potential accident consequences of airborne releases at nuclear power plants (NRC 1982).

The database of airborne dose vs. distance was calculated with a consistent, documented set of inputs that were specifically chosen for TA-V needs. The MACCS2 inputs represent the assumptions for dose calculation in the dose vs. distance database (Naegeli 1999). Naegeli calculated the dose from $1.0 \mathrm{Ci}$ of a single isotope at ten distance ranges for three release conditions. For this analysis for the AHCF, the results of Naegeli's calculations were scaled to the estimated respirable curies release (Table 3-7). The conditions include releases from the AHCF stack, releases at ground level with buildingwake effects, and ground releases without building-wake effects.

The dose was calculated for a hypothetical uniform-density population during a 24-hour radiation exposure. The database provides whole body EDEs. The long-term inhalation committed effective dose equivalent (CEDE) over 50 years and cloud shine (immersion) dose equivalent to an individual were the exposure pathways adopted by DOE (1997a) for calculation of dose consequences for hazard category characterization. The whole body EDE calculated by MACCS2 for the dose vs. distance database also includes external ground shine dose and internal resuspension inhalation dose pathways (both very minor contributors). Thus, the dose calculated for the accident analysis with the dose vs. distance database will be slightly larger and more conservative than dose calculated with the exposure pathways of DOE (1997a) alone.

Software quality assurance for the MACCS2 code was provided through a limiteddistribution beta test with DOE users and through a formal, independent verification study of the code package by the University of New Mexico, which included detailed hand calculations. An independent analyst, familiar with the MACCS2 code and its applications, validated the standard input. ${ }^{4}$

\subsection{Chemical Dose Consequence Evaluation}

The consequences of chemical release are estimated using the CAMEO (Computer Aided Management of Emergency Operations) computer model (National Safety Council, 1997). CAMEO was designed by the National Oceanic and Atmospheric Administration and the EPA. CAMEO is recommended by EPA for demonstrating compliance with 40 CFR 68 (EPA 1999). This model is designed to help emergency planners, facility

\footnotetext{
${ }^{4}$ J. Liscum-Powell, 1997, "Review of MACCS2 Input Files," Sandia National Laboratories memorandum to R. E. Naegeli, June 18, 1997.
} 
operators, and first responders plan for and safely handle chemical accidents. CAMEO's air model is ALOHA (Areal Locations of Hazardous Atmospheres; National Safety Council, 1997). ALOHA estimates chemical concentrations downwind from the source, considering the physical characteristics of the release site, the atmospheric conditions, and the circumstances of the release.

For this analysis, atmospheric conditions are selected to reflect worst-case, rather than average, conditions. A Pasquill-Gifford Stability Class of D (neutral, i.e., heavy overcast, day or night) was used for the analysis. The use of Class $D$ rather than Class $F$ is consistent with methods used by SNL's emergency planning program and with DOE guidance (DOE 1997b), which recommends use of the 95 percentile worst-case wind conditions. Release conditions are assumed to be 6 pounds per minute for 10 minutes at ground level. Exposure is averaged over one hour.

The parameters listed above are consistent with the guidance provided by the EPA on evaluation of consequences from airborne release of chemicals (EPA 1999).

\subsubsection{Evaluation Guidelines}

This section discusses evaluation guidelines for radioactive and chemical sources.

\subsection{Radioactive Source Evaluation Guidelines}

The evaluation guideline for radiation dose to the public is typically set at $25 \mathrm{rem}$ total effective dose equivalent (TEDE) to the whole body at the site boundary. Calculated doses to the maximally exposed individual of the public at the site boundary for a DBA must be less than or equal to $25 \mathrm{rem}$ to be within the evaluation guidelines.

A TEDE of 25 rem at the site boundary has precedence as a siting criterion in 10 CFR 100, Reactor Site Criteria, for the Nuclear Regulatory Commission in Section 100.11. A whole body dose of $25 \mathrm{rem}$ is generally accepted as a dose that will not cause acute health effects (that is, health effects that manifest themselves within a few hours or days of irradiation) (see Section 3.4.2.5.4).

For a Category 3 Nuclear Facility, such as the AHCF, the dose at the site boundary by definition should be well below evaluation guidelines. And, in fact, doses from the maximum possible release from this facility, given several generic release scenarios, are minimal, as illustrated in Table 3-7. The primary purpose of further analysis is to determine the likelihood that specific releases will bound or be representative of similar worker-safety and environmental-protection scenarios.

\subsection{Chemical Source Evaluation Guidelines}

The evaluation guideline for chemical exposure to the public at the site boundary is the Emergency Response Planning Guidelines Level 2 (ERPG-2), as recommended by DOE (1994b). 


\subsubsection{Design Basis Accidents}

Each DBA in the accident analyses is developed here using the graded approach suggested by the DOE (1994a). Quantitative analyses are only required to the extent necessary to demonstrate that evaluation guidelines are not exceeded. For nonreactor nuclear facilities, there is no need for probabilistic or quantitative risk assessment, and the use of bounding assumptions and less detailed physical modeling in accident analysis is appropriate. Appendix 3-C provides a detailed analysis of each accident.

Criticality has been excluded from the DBAs on the basis of incredibility, as discussed in Section 3.3.2.3.5.

\subsubsection{Fire Inside Hot Cell—Ignition of Flammable Materials}

Fire in the hot cell is an internally initiated DBA. Flammable materials are limited in the existing and expected waste stream; however, the expected waste and material are extremely diverse and in some cases may be poorly characterized. Flammable materials could be presented for processing in the hot cell in the future. Potential ignition sources include sparks from the electric switches and controls for the jib crane, the exhaust fan, and the lights and cameras.

\subsection{Scenario Development}

The sequences of events related to processing flammable material or waste components were evaluated to identify initiating and mitigative events that could affect the potential for a fire. The accident was examined using event tree analysis. Detailed event tree descriptions and results are contained in Appendix 3-C.

The information available on the existing inventory of waste and materials does not include data on flammability of components. However, process knowledge indicates that the presence of flammable materials will be limited. In this analysis, flammable materials were assumed to make a rare appearance, once every ten years. Routine waste characterization procedures may indicate the possible presence of a flammable material. If flammable materials are identified, administrative controls will limit flammable materials to levels recommended by UBC Table 3-D (ICBO 1997) for unsprinkled areas. However, flammable materials may not be detected and thus be introduced into the hot cell.

For ignition to occur, the flammable material must be released from its container. This could happen through a leak or spill. Other than flashing of the vapors (see Section 3.4.2.5), ignition of flammable materials would require fairly close proximity to an ignition source. The available ignition sources are typically a few meters away from the waste handling area, and direct ignition is considered incredible. Vapors could collect above a pool of flammable liquids, deflagrate on contact with a spark or hot motor, and ignite the pool below. The ventilation system is equipped with fire detectors tied to alarms. Manual fire suppression will be applied by the operator if a fire is detected, but waste will occasionally remain in the hot cell overnight. If ignition occurs while the 
waste is unattended, there will be no opportunity for suppression. A fire screen and the distance between the hot cell and the HEPA filters will protect the filters from burning initially; however, the HEPA filters were not considered in the consequence analysis.

The probability of ignition of other sources, such as combustible oils, was also considered in the hazard evaluation. However, flammable material was considered to be the most likely source. The sequence of events leading to a fire from flammable material is similar to those leading to fires from other sources. Therefore, this DBA is representative for this type of accident.

\subsection{Source Term Analysis}

DOE (1997a) limits the quantities of radioactive material allowed within a Category 3 nuclear facility. The limits may be reached either by a single isotope or by the sum of fractions of various isotopes. For the purposes of this analysis, the source term was conservatively chosen at Category 2 threshold quantities of $\mathrm{Pu}-239$ as representing the greatest potential health hazard if dispersed.

The only likely dispersal mechanism is fire; if ignition occurs, the entire inventory is assumed to be involved. This analysis is conservative because no credit is taken for the following potential mitigators: plutonium in the current inventory is probably in oxide form, for the HEPA filter, for plate-out, or for building leak rate.

\subsection{Consequence Analysis}

The method used to estimate the dose arising from release of the source term is described in Section 3.4.1.2.1. These dose estimates incorporate a number of extremely conservative assumptions, for example,

- The model assumes that an accident releases $100 \%$ of the airborne particles.

- The model assumes that the worker is exposed to the radioactive plume for 24 hours without evacuating.

- The model assumes the presence of Category 2 threshold quantities of Pu-239, even though less than $1 \%$ of the packages in the SNL legacy inventory are known to contain this inventory.

- No credit was taken for the unlikelihood of the simultaneous presence of Category 2 threshold quantities of $\mathrm{Pu}-239$ and the required quantities of the initiator material.

The estimated dose to colocated workers is well below levels that have life-threatening or acute health effects. Dose to workers in the immediate vicinity is expected to be limited by procedures requiring evacuation in the event of an uncontained fire. Severe contamination of the facility would result from this scenario. 


\subsection{Comparison to Guidelines}

Off-site doses are well below the evaluation guidelines of $25 \mathrm{rem}$.

\subsection{Summary of Safety-Class SSCs and TSR Controls}

No safety-class equipment or associated TSRs are required to mitigate this scenario. Safety-significant SSCs and associated TSRs are described in Section 3.3.2.3 and its subsections. Administrative control procedures are required to ensure that the radioactive material inventory in the hot cell and the High Bay is less than the Hazard Category 2 thresholds. Administrative controls will limit flammable materials in the hot cell to levels recommended by UBC Table 3-D (ICBO 1997) for unsprinkled areas.

\subsubsection{Fire Inside Hot Cell-Autoignition of Reactive Metals}

Autoignition of reactive metals in the hot cell is an internally initiated DBA. Sodium is a known component of the existing and expected waste stream. Sodium may enter the hot cell during characterization, for repackaging prior to shipment for treatment off site, or possibly for extraction from the waste in the hot cell.

\subsection{Scenario Development}

The sequences of events related to processing reactive metals were evaluated to identify initiating and mitigative events that could affect the potential for a fire. The accident was examined using event tree analysis. Detailed event tree descriptions and results are contained in Appendix 3-C.

The information available on the existing inventory of waste and materials indicates that a small percentage of the waste packages considered for immediate processing in the hot cell contain sodium. Sodium is expected to be present as a much smaller fraction of future waste. Sodium will be processed using strict process controls. Ignition will require failure of administrative controls. Available sodium may ignite from humidity in the air. The ventilation system is equipped with alarms, and manual fire suppression will be applied by the operator if a fire is detected. Administrative controls will prohibit leaving exposed sodium unattended in the hot cell. A fire screen will protect the HEPA filters, and the filters are located at least $6 \mathrm{~m}(20 \mathrm{ft})$ from the fire screen; however, attenuation of release by HEPA filters is conservatively omitted from the analysis.

This analysis considers sodium as the most likely reactive metal to appear in the hot cell. It conservatively assumes that sodium will appear with the frequency encountered in the waste considered for immediate processing, even though future waste streams are expected to contain less reactive metals. The sequence of events leading to a fire from sodium processing is similar to those resulting in a fire from other reactive materials. Therefore, this DBA is representative for this type of accident. 


\subsection{Source Term Analysis}

DOE (1997a) limits the quantities of radioactive material allowed within a Category 3 nuclear facility. The limits may be reached either by a single isotope or by the sum of fractions of various isotopes. For the purposes of this analysis, the source term was conservatively chosen at Category 2 threshold quantities of $\mathrm{Pu}-239$ as representing the greatest potential health hazard if dispersed. No actual waste packages are represented by this analysis because there are no known packages containing both sodium and plutonium.

The only likely dispersal mechanism is fire; if ignition occurs, the entire inventory is assumed to be released.

\subsection{Consequence Analysis}

The method used to estimate the dose arising from release of the source term was described in Section 3.4.1.2. These dose estimates incorporate a number of extremely conservative assumptions (Section 3.4.1.2.3). The estimated dose to colocated workers is well below levels that have life-threatening or acute health effects. Dose to workers in the immediate vicinity is expected to be limited by procedures requiring evacuation in the event of an uncontained fire. Severe contamination of the facility would result from this scenario.

\subsection{Comparison to Guidelines}

Doses are well below the evaluation guidelines.

\subsection{Summary of Safety-Class SSCs and TSR Controls}

No safety-class equipment or associated TSRs are required to mitigate this scenario. Safety-significant SSCs and associated TSRs are described in Section 3.3.2.3. Administrative control procedures are required to ensure that the radioactive material inventory in the hot cell and the High Bay is less than the Hazard Category 2 thresholds. Administrative control procedures for handling sodium and to ensure that exposed sodium is not left unattended in the hot cell are also necessary.

\subsubsection{Fire Outside Hot Cell-Vehicular Equipment Malfunction}

Fire in the High Bay is an internally initiated DBA, initiated by malfunction associated with a forklift moving material or waste. The only likely dispersal mechanism is fire; if ignition occurs, it is assumed to release the radioactive components of material or waste. This analysis embodies several highly conservative assumptions including that the container is breached and that the entire Pu inventory is available for ignition (although the current $\mathrm{Pu}$ waste is largely oxidized). 


\subsection{Scenario Development}

The sequences of events related to processing flammable material or waste components were evaluated to identify initiating and mitigative events that could affect the potential for a fire arising from vehicle malfunction. The accident was examined using event tree analysis. Detailed event tree descriptions and results are contained in Appendix 3-C.

The initiating event is failure of equipment associated with a vehicle transporting material or waste. Examples are catastrophic battery failure, electrical short, or leakage of hydraulic/brake fluid onto a hot brake surface. The fire could be extinguished manually by the vehicle operator. Failing that, the building fire detection and automatic sprinkler system should extinguish the fire prior to ignition of the waste package.

It is the judgment of SNL's Fire Protection Engineers that a vehicle fire is the most likely source of ignition outside the hot cell. The sequence of events leading to a fire from vehicular equipment malfunction is similar to those resulting in a fire from other equipment within the High Bay. Therefore, this DBA is representative for this type of accident.

\subsection{Source Term Analysis}

DOE (1997a) limits the quantities of radioactive material allowed within a Category 3 nuclear facility. The limits may be reached either by a single isotope or by the sum of fractions of various isotopes. For the purposes of this analysis, the source term was conservatively chosen at Category 2 threshold quantities of Pu-239 as representing the greatest potential health hazard if dispersed.

The only likely dispersal mechanism is fire; if ignition occurs, the entire inventory is assumed to be involved.

\subsection{Consequence Analysis}

The method used to estimate the dose arising from release of the source term is described in Section 3.4.1.2.1. These dose estimates incorporate a number of extremely conservative assumptions (Section 3.4.1.2.3). The estimated dose to colocated workers is well below levels that have life-threatening or acute health effects. Dose to workers in the immediate vicinity is expected to be limited by procedures requiring evacuation in the event of an uncontained fire. Severe contamination of the facility would result from this scenario.

\subsection{Comparison to Guidelines}

Off-site doses are well below the evaluation guidelines of $25 \mathrm{rem}$.

\subsection{Summary of Safety-Class SSCs and TSR Controls}

No safety-class equipment or associated TSRs are required to mitigate this scenario. Safety-significant SSCs and associated TSRs are described in Section 3.3.2.3. 
Administrative controls procedures are required to ensure that the radioactive material inventory in the hot cell and the High Bay is less than the Hazard Category 2 thresholds. Operator training is required to limit the potential for a vehicular fire and to optimize effectiveness of manual fire suppression should a fire occur.

\subsubsection{Earthquake Initiates Fire Outside Hot Cell}

A fire initiated by an earthquake is an externally initiated DBA. Disruption of natural gas lines by collapse of the building could release natural gas from lines located in the Mid Bay. If lower explosion limit (LEL) levels of natural gas develop in the building, in spite of the collapse of the building and lack of an enclosed area to contain the gas, deflagration could occur and result in a fire.

\subsection{Scenario Development}

The accident was examined using event tree analysis. Detailed event tree descriptions and results are contained in Appendix 3-C.

A Design Basis Earthquake is expected to occur with an annual frequency of $7 \times 10^{-4}$. The High Bay is not rated for earthquake and is conservatively assumed to collapse. The sequence of conservative assumptions is as follows. The building collapses on the containers. The release of radioactive materials from their containers is assumed. Collapse of the building causes breakage of natural gas lines. Natural gas supply remains uninterrupted; natural gas is released. Electrical ignition sources also are uninterrupted and cause deflagration of natural gas. A fire occurs, sustained by flammable and combustible material in the building. The building fire protection system is damaged by the earthquake and fails to function. Plutonium reaches the self-sustaining temperature for combustion.

Earthquake is the most probable of the external events retained from the external event screening (Appendix 3-D). The earthquake is assumed to release the maximum potential source. Therefore, this DBA is bounding for this type of accident.

\subsection{Source Term Analysis}

DOE (1997a) limits the quantities of radioactive material allowed within a Category 3 nuclear facility. The limits may be reached either by a single isotope or by the sum of fractions of various isotopes. For the purposes of this analysis, the source term was conservatively chosen at Category 2 threshold quantities of Pu-239 as representing the greatest potential health hazard if dispersed.

The only likely dispersal mechanism is fire; if ignition occurs, the entire inventory is assumed to be involved.

\subsection{Consequence Analysis}

The method used to estimate the dose arising from release of the source term is described in Section 3.4.1.2.1. These dose estimates incorporate a number of extremely conserva- 
tive assumptions (Section 3.4.1.2.3). The estimated dose to colocated workers is well below levels that have life-threatening or acute health effects. Safety considerations for workers inside the building are dominated by the consequences of the earthquake itself, with release of hazardous material a relatively minor consideration.

\subsection{Comparison to Guidelines}

Off-site doses are well below the evaluation guidelines of $25 \mathrm{rem}$.

\subsection{Summary of Safety-Class SSCs and TSR Controls}

No safety-class equipment or associated TSRs are required to mitigate this scenario. Safety-significant SSCs and associated TSRs are described in Section 3.3.2.3. Administrative control procedures are required to ensure that the radioactive material inventory in the hot cell and the High Bay is less than the Hazard Category 2 thresholds.

\subsubsection{Deflagration Inside Hot Cell-Ignition of Flammable Gas}

A deflagration inside the hot cell, initiated by the accumulation of flammable gas vapors above the LEL, is an internally initiated DBA. Vapors could be ignited by sparks from electrical switches or controls.

\subsection{Scenario Development}

The accident was examined using event tree analysis. Detailed event tree descriptions and results are contained in Appendix 3-C.

The event is initiated by the planned or unplanned release of flammable gas within the hot cell. Flammable gases are not known constituents of existing waste; however, gases may be received in the future as either known or unknown constituents of the waste. The frequency of processing flammable gases was assumed to be once every 10 years. If flammable gases are known or identified in the waste package, administrative controls will apply. If the gases are unknown, or administrative controls fail, a release of the gas could lead to a deflagration from an electrical spark or heat. The HEPA filter is assumed to be compromised by the deflagration.

The deflagration is assumed to lead to release of threshold quantities for Category 2 nuclear facility of Pu-239 as a fine particulate. Flammable gas is the most likely source of vapors, although this scenario could also be initiated by vapors from a volatile liquid. The sequence of events leading to a flammable-gas deflagration is similar to those resulting in a deflagration of other materials within the hot cell. Therefore, this DBA is representative for this type of accident.

\subsection{Source Term Analysis}

DOE (1997a) limits the quantities of radioactive material allowed within a Category 3 nuclear facility. The limits may be reached either by a single isotope or by the sum of fractions of various isotopes. For the purposes of this analysis, the source term was 
conservatively chosen at Category 2 threshold quantities of $\mathrm{Pu}-239$ as representing the greatest potential health hazard if dispersed.

The deflagration is assumed to involve the entire inventory of Pu-239 as a fine particulate.

\subsection{Consequence Analysis}

The method used to estimate the dose arising from release of the source term is described in Section 3.4.1.2.1. These dose estimates incorporate a number of extremely conservative assumptions (Section 3.4.2.1.3). The estimated dose to colocated workers is well below levels that have life-threatening or acute health effects. Dose to workers in the immediate vicinity is expected to be limited by procedures requiring evacuation following a deflagration. Severe contamination of the facility would result from this scenario.

\subsection{Comparison to Guidelines}

Off-site doses are well below the evaluation guidelines of $25 \mathrm{rem}$. Worker exposures will not result in any acute health effects.

\subsection{Summary of Safety-Class SSCs and TSR Controls}

No safety-class equipment or associated TSRs are required to mitigate this scenario. Safety-significant SSCs and associated TSRs are described in Section 3.3.2.3. Administrative control procedures are required to ensure that the radioactive material inventory in the hot cell and the High Bay is less than the Hazard Category 2 thresholds. Administrative controls will limit flammable materials in the hot cell to levels recommended by UBC Table 3-D (ICBO 1997) for unsprinkled areas.

\subsubsection{External Exposure to Worker-Failure of Passive Radiation Shielding}

Simultaneous failure of passive radiation shielding and surveillance mechanisms is an internally initiated DBA resulting in worker radiation exposure. This scenario does not examine the effects of airborne contaminants.

\subsection{Scenario Development}

The accident was examined using event tree analysis. Detailed event tree descriptions and results are contained in Appendix 3-C.

The event is initiated by the development of a breach that allows radiation streaming in the primary confinement structure of the hot cell. The streaming could occur by settling of the sand in the wall or other similar confinement failures. Routine Health Physics surveillance should detect the streaming. If this fails, self-alarming personal dosimeters should warn workers of the presence of ionizing radiation, resulting in worker evacuation and reduction of exposure. 


\subsection{Source Term Analysis}

Material in the hot cell by definition will present an external radiation hazard. This analysis assumes continuous operation of the hot cell. Sources could be as high as $6 \mathrm{kCi}$ of mixed fission products in the hot cell. Therefore, this DBA is bounding for this type of accident.

\subsection{Consequence Analysis}

The consequence is assumed to be worker exposure above workplace guidelines (SNL 1999). No attempt was made to estimate the level of exposure because the probability of exposure is less than $10^{-9}$, which is well below the threshold of credibility.

\subsection{Comparison to Guidelines}

The level of worker exposure was not estimated.

\subsection{Summary of Safety-Class SSCs and TSR Controls}

No safety-class equipment or associated TSRs are required to mitigate this scenario. Safety-significant SSCs and associated TSRs are described in Section 3.3.2.3. Administrative control procedures are required to ensure that the Radiological Protection Program is implemented and that self-alarming personal dosimeters are worn when appropriate.

\subsubsection{External Exposure to Worker-Exposed Source Above Permanent Shield Wall}

Exposure of a colocated worker to an unshielded radioactive source is an internally initiated DBA. The most probable scenario is the encroachment of a worker into the high radiation field that will surround Building 6597 while a highly radioactive source is elevated above the permanent shield wall for insertion into the hot cell.

\subsection{Scenario Development}

The accident was examined using event tree analysis. Detailed event tree descriptions and results are contained in Appendix 3-C.

The accident is initiated when a radioactive source that presents an unacceptable hazard as defined by the RPPM is hoisted above the hot-cell wall. Power failure occurs about 3 times a year. This operation may occur 20 times in the first year of operation. If a power failure occurs during the operation, a temporary generator will be used to continue the movement of the source. The generator may also fail, prolonging the potential for exposure. Surveillance mechanisms, specifically surveillance cameras with screens at the operator stations, will not be operational if power fails. Administrative controls will be used to physically intercept any potential intruders into the radiation area. This DBA is representative for this type of accident. 


\subsection{Source Term Analysis}

The source may be as high as $6 \mathrm{kCi}$ of mixed fission products, 120 days post-irradiation.

\subsection{Consequence Analysis}

The consequence is assumed to be worker exposure above workplace guidelines (SNL 1999). The calculated dose rate at the highest point, outside the north roll-up doors $6.1 \mathrm{~m}$ (20 ft) away, is estimated to be $13.3 \mathrm{rem} / \mathrm{hr}$, assuming a $6 \mathrm{kCi}$ source of mixed fission products, 120 days post-irradiation (Duong 1999). No credit is taken for shielding provided by the walls or doors of Building 6597. No package currently in SNL's inventory has a source greater than $500 \mathrm{Ci}$.

\subsection{Comparison to Guidelines}

Although the level of worker exposure would exceed workplace guidelines (SNL 1999), consequences of this exposure are low.

\subsection{Summary of Safety-Class SSCs and TSR Controls}

No safety-class equipment or associated TSRs are required to mitigate this scenario. Safety-significant SSCs and associated TSRs are described in Section 3.3.2.3. Administrative control procedures are required to ensure that camera surveillance is performed during normal transfer operations and that spotters are positioned to physically intercept potential intruders.

\subsubsection{Chemical Release from the AHCF}

This accident assumes the release, by any mechanism, of the maximum allowable quantity of a Process Safety Management (29 CFR 1910.119) chemical from the AHCF. The consequences are bounded by the release of 60 pounds of hydrogen fluoride gas (25\% of PSM quantities). The gas could originate from breach of a container of uranium hexafluoride.

Dispersion analysis indicates that ERPG-2 levels of HF gas would extend only 271 feet from Building 6597 (Walker 1999). This is well within the exclusion area boundary, $3000 \mathrm{~m}$ away. In accordance with the guidance provided by DOE (1997a), no further analysis of chemical dispersion will be done.

\subsubsection{Beyond Design Basis Accidents}

A beyond-design-basis accident for the AHCF could include an earthquake that caused collapse of the hot cell. The consequences of this accident are bounded by the earthquake and fire in the High Bay, because the inventory of the High Bay and hot cell, as a single nuclear facility, cannot exceed Category 2 threshold quantities of radionuclides. Collapse of the hot cell, in addition to the High Bay, could not release any additional quantities of radioactive material. 


\subsection{REFERENCES}

(AIChE 1985)

(Aldrich et al. 1982)

(Chanin and Young 1997)

(DOE 1997a)

(DOE 1997b)

(DOE 1996a)

(DOE 1996b)

(DOE 1994a)

(DOE 1994b)
American Institute of Chemical Engineers, Hazard Evaluation Techniques, American Institute of Chemical Engineers, New York, NY, 1985.

Aldrich, D. C., J. L. Sprung, D. J. Alpert, K. Diegert, R. M. Ostmeyer, L. T. Ritchie, and D. R. Strip, Technical Guidance for Siting Criteria Development, NUREG/CR-2239, SAND81-1539, Sandia National Laboratories, Albuquerque, NM, 1982.

Chanin, D. I., and M. L. Young, Code Manual for MACCS2: Volume 1, User's Guide, SAND97-0594 v. 1, Sandia National Laboratories, Albuquerque, NM, March 1997.

U.S. Department of Energy, "Hazard Categorization and Accident Analysis Techniques for Compliance with DOE Order 5480.23, Nuclear Safety Analysis Reports," DOE-STD-1027-92, Change Notice No. 1, U.S. Department of Energy, Washington, DC, 1997.

U.S. Department of Energy, "Emergency Management Guide, Volume II, Hazards Surveys and Hazards Assessments," DOE G 151.1-1, U.S. Department of Energy, Washington, DC, 1997.

U.S. Department of Energy, "Hazard and Barrier Analysis Guidance Document," U.S. Department of Energy, Washington, DC, 1996.

U.S. Department of Energy, DOE Order 420.1, Chg. 2, "Facility Safety," U.S. Department of Energy, Washington, DC, October 24, 1996.

U.S. Department of Energy, DOE-STD-3009-94, "Preparation Guide for U.S. Department of Energy Nonreactor Nuclear Facility Safety Analysis Reports," U.S. Department of Energy, Washington, DC, July 1994.

U.S. Department of Energy, DOE Order 5480.23, Chg. 1, "Nuclear Safety Analysis Reports," U.S. Department of Energy, Washington DC, March 10, 1994. 
(DOE 1994c)

(Duong 1999)

(Eckerman et al. 1989)

(Eckerman and Ryman 1993)

(EPA 1999)

(ICBO 1997)

(Mahn 1995)

(Merrick 1998)

(Naegeli 1999)
U.S. Department of Energy, Release Fractions/Rates and Respirable Fractions for Nonreactor Nuclear Facilities, DOE-HDBK-3010-94, U.S. Department of Energy, Washington DC, December 1994.

Duong, H., "Dose Rate East of Building 6597," Memorandum to Debby Oscar, Sandia National Laboratories, Albuquerque, NM, July 26, 1999.

Eckerman, K. F., A. B. Wolbarst, and A. C. B. Richardson, "Limiting Values for Radionuclide Intake and Air Concentration and Dose Conversion Factors for Inhalation, Submersion, and Ingestion," Federal Guidance Report 11, EPA 520/1-88-020, second printing with corrections, U.S. Environmental Protection Agency, Washington, DC, 1989.

Eckerman, K. F., and J. C. Ryman, 1993, "External Exposure to Radionuclides in Air, Water, and Soil," Federal Guidance Report 12, EPA 402-R-93-081, U.S. Environmental Protection Agency, Washington, DC, 1993.

U.S. Environmental Protection Agency, Risk Management Program Guidance for Offsite Consequence Analysis, EPA 550-B-99-009, U.S. Environmental Protection Agency, Washington, DC, April 1999.

International Conference of Building Officials, "1997 Uniform Building Code," International Conference of Building Officials, Whittier, California, April 1997.

Mahn, J. A., G. William Hannaman, and Paul Kryska, "Qualitative Methods for Assessing Risk," SAND950320, Sandia National Laboratories, Albuquerque, NM, April, 1995.

Merrick \& Company, Advanced Structural Investigation for the Auxiliary Hot Cell Facility Modifications at Sandia National Laboratory Building 6597, Merrick \& Company, Albuquerque, NM, 1998.

Naegeli, R. E., MACCS2 Single Isotope Airborne Dose Versus Distance Database, DRAFT, Sandia National Laboratories, Albuquerque, NM, 1999. 
(National Safety Council 1997) National Safety Council, “Computer Aided Management of Emergency Operations" (CAMEO), Version 1.1, (with "Areal Locations of Hazardous Atmospheres" (ALOHA), Version 5.2.1), February 5, 1997.

(NRC 1982)

(NRC 1975)

U.S. Nuclear Regulatory Commission, Atmospheric Dispersion Models for Potential Accident Consequence Assessment at Nuclear Power Plants, Reg. Guide 1.145, Rev. 1 (Reissued February 1983), U.S. Nuclear Regulatory Commission, Washington, DC, November 1982.

U.S. Nuclear Regulatory Commission, Reactor Safety Study: Calculation of Reactor Accident Consequences, WASH-1400, NUREG 75/014, Appendix 6, U.S. Nuclear Regulatory Commission, Washington, DC, 1975.

(Philbin 1998)

Philbin, J. S., "Nuclear Criticality Safety," GN470072, Issue C, Sandia National Laboratories, Albuquerque, NM, January 28, 1998.

(SNL 1999)

Sandia National Laboratories, "Radiological Protection Procedures Manual," CPR400.1.1.32, Sandia National Laboratories, Albuquerque, NM, January 21, 1999.

(Walker 1999)

Walker, Sharon A., "Results of Dispersion Analysis for Accidental Chemical Release from Building 6597, Sandia National Laboratories," Internal Memorandum, Sandia National Laboratories, Albuquerque, NM, July 21, 1999. 


\section{CHAPTER 4}

\section{SAFETY STRUCTURES, SYSTEMS, AND COMPONENTS}

\subsection{INTRODUCTION}

The purpose of this chapter is to provide information that will satisfy the requirements of DOE 5480.23, paragraph 8.b.(3)(d) ${ }^{1}$ and paragraph 8.b.(3)(k) ${ }^{2}$. This chapter also includes applicable information that will partially satisfy the requirements of DOE 5480.23, paragraph(s) 8.b.(3)(b),(f), and (u).

The chapter identifies and describes SSCs that were assumed explicitly in the hazard and accident analysis to perform a safety function. That is, it identifies SSCs that are necessary to satisfy evaluation guidelines, provide defense in depth, or contribute to worker safety. It discusses the basis for designating each of these SSCs as safety-related. Finally, it describes the applicable functional requirements, interfaces with other SSCs, and evaluations required to demonstrate performance of each SSC's safety functions under all expected accident or environmental conditions.

\subsection{REQUIREMENTS}

This section identifies the design codes, standards, regulations, and DOE orders that are required to establish the safety basis for the AHCF. The requirements pertinent to the safety analysis and scope of this chapter are listed below:

- DOE Order 420.1, Chg. 2, "Facility Safety" - This order sets forth the basic nuclear safety, fire protection, nuclear criticality safety, and natural phenomena mitigation design requirements for new DOE facilities and major modifications of existing ones (DOE 1996a).

- DOE Order 5480.22, Chg. 2, "Technical Safety Requirements" - This order specifies the criteria, content, scope, format, approval process, revision process, and reporting requirements for DOE nuclear facility Technical Safety Requirements (DOE 1996b).

- DOE Order 5480.23, "Nuclear Safety Analysis Reports" - This order specifies requirements for developing and documenting safety analyses that establish the adequacy of the safety bases for DOE nuclear facilities (DOE 1994b).

- DOE-STD-3009-94, "Preparation Guide for U.S. Department of Energy Nonreactor Nuclear Facility Safety Analysis Reports" - This standard

\footnotetext{
'As amplified in Attachment 1, paragraph(s) 4.f.(3)(d)4b and 4.f.(3)(d)4c, of the Order (Topic 4).

${ }^{2}$ As amplified in Attachment 1, paragraph(s) 4.f.(3)(d) 11n, of the Order (Topic 11).
} 
describes a SAR preparation method that satisfies the requirements of DOE Order 5480.23 and is acceptable to the DOE (DOE 1994a).

- DOE-STD-1073, "Configuration Management Standard" - This standard presents the program criteria and implementation guidance for an operational configuration management program for $\mathrm{DOE}$ nuclear facilities in the operational phase (DOE 1993).

\subsection{SAFETY Class SYSTEMS, STRUCTURES, AND COMPONENTS}

DOE (1994a) divides safety SSCs into two categories: (1) safety-class and (2) safetysignificant. DOE defines safety-class SSCs (SCSSCs) as those SSCs, including environmental monitors and portions of process systems, whose failure could adversely affect the environment or safety and health of the public as identified by safety analysis (DOE 1994a). "Adversely affect" means to exceed off-site evaluation guidelines (see Section 3.4.1.3). SCSSCs are systems, structures, or components whose preventive or mitigative function is necessary to keep hazardous material exposure to the public below the evaluation guidelines.

Because of the nature of the AHCF and its Category 3 hazardous material inventory, no unmitigated accident scenario will result in off-site exposures greater than the off-site evaluation guidelines, as evaluated and described in Chapter 3. Therefore, no safety-class SSCs have been identified for the AHCF.

\subsection{SAFETY-SignifiCANT STRUCTURES, SYSTEMS, AND COMPONENTS}

DOE (1994a) defines safety-significant SSCs (SSSSCs) as SSCs not designated as SCSSCs but whose preventive or mitigative function is a major contributor to defense in depth (i.e., reduces likelihood of uncontrolled hazardous material release) or to worker safety as determined from hazard analysis. SSSSC designations based on worker safety are limited to those systems, structures, or components whose failure is estimated to result in an acute worker fatality or serious injuries to workers. Serious injuries, as used here, are those requiring medical treatment for immediately life-threatening conditions or permanently disabling injuries (e.g., loss of eye or limb) from other than standard industrial hazards. Potential latent effects (e.g., potential carcinogenic effects of radiological exposure or uptake) are specifically excluded.

The most important aspect of classifying SSCs is the identification of design and operational requirements associated with them (DOE 1993). Implementation of requirements should be correlated to the safety classification of SSCs, that is, their importance to safety. Implementation of design requirements also depends on whether the facility is new or already operating. 
Operational requirements also depend on other factors (e.g., environment, mission, and remaining lifetime of the facility) (DOE 1993). As with design requirements, implementation of operational requirements can be graded based on the hazard categorization of the facility and on the safety classification of the SSCs, as discussed in Chapter 3.

The AHCF safety-related SSCs provide defense in depth or worker safety. The ventilation system and HEPA filters reduce the consequence of an accidental release of radioactive material (although unmitigated consequences cannot exceed the off-site evaluation guideline of $25 \mathrm{rem}$ ). The remaining safety-related SSCs, in contrast, primarily contribute to worker safety for the AHCF. Chapter 3 evaluates these potential consequences and identifies the SSCs that mitigate them (Table 4-1). Each SSC is discussed below.

\subsubsection{Hot Cell Structure}

The hot cell houses operations associated with the handling of unshielded hazardous and radioactive material. Its primary function is to shield workers from direct radiation, but it also provides confinement and supports the function of the ventilation system and HEPA filters.

\subsubsection{Safety Function}

The structure of the hot cell serves two safety-related purposes: (1) it provides radiation shielding for workers, and (2) it confines radioactive materials. Building 6597 structures serve no functions that meet safety-related criteria.

Purpose 1 promotes worker protection by providing barriers to potentially lethal doses of ionizing radiation from radioactive material operations conducted inside the hot cell. Purpose 2 provides defense in depth by creating a barrier, in conjunction with the ventilation system, to the potential uncontrolled movement of radioactive materials within the AHCF.

\subsubsection{System Description}

The major structures that perform a safety-related function for the hot cell are walls, leaded-glass windows, and access shield plugs. The hot cell is described briefly here; a detailed description can be found in Section 2.4.2.1.

The walls and roof of the hot cell are constructed of interlocking elements of steel, sand, and concrete. Inside working-space dimensions are $3 \mathrm{~m} \mathrm{(10} \mathrm{ft)} \mathrm{square} \mathrm{with} \mathrm{a} \mathrm{clear} \mathrm{inside}$ height of $4.2 \mathrm{~m}(13 \mathrm{ft} 10 \mathrm{in}$.).

The walls are composed of $61 \mathrm{~cm}$ (24 in.) of sand between 20-cm (8-in.)-thick concrete panels. Steel tie rods hold the concrete panels in place. All wall seams are offset to prevent direct shine through. Two Type " $\mathrm{C}$ " radiation shielding windows are incorporated in the south and west walls of the hot cell. A 46-cm (18-in.)-thick concrete foundation mat supports the hot cell. The floor inside the hot cell is raised $10 \mathrm{~cm}$ (4 in.) above the floor level of Building 6597 to prevent shine under the walls. The floor and walls are covered 
Table 4-1. AHCF Safety-Significant SSCs

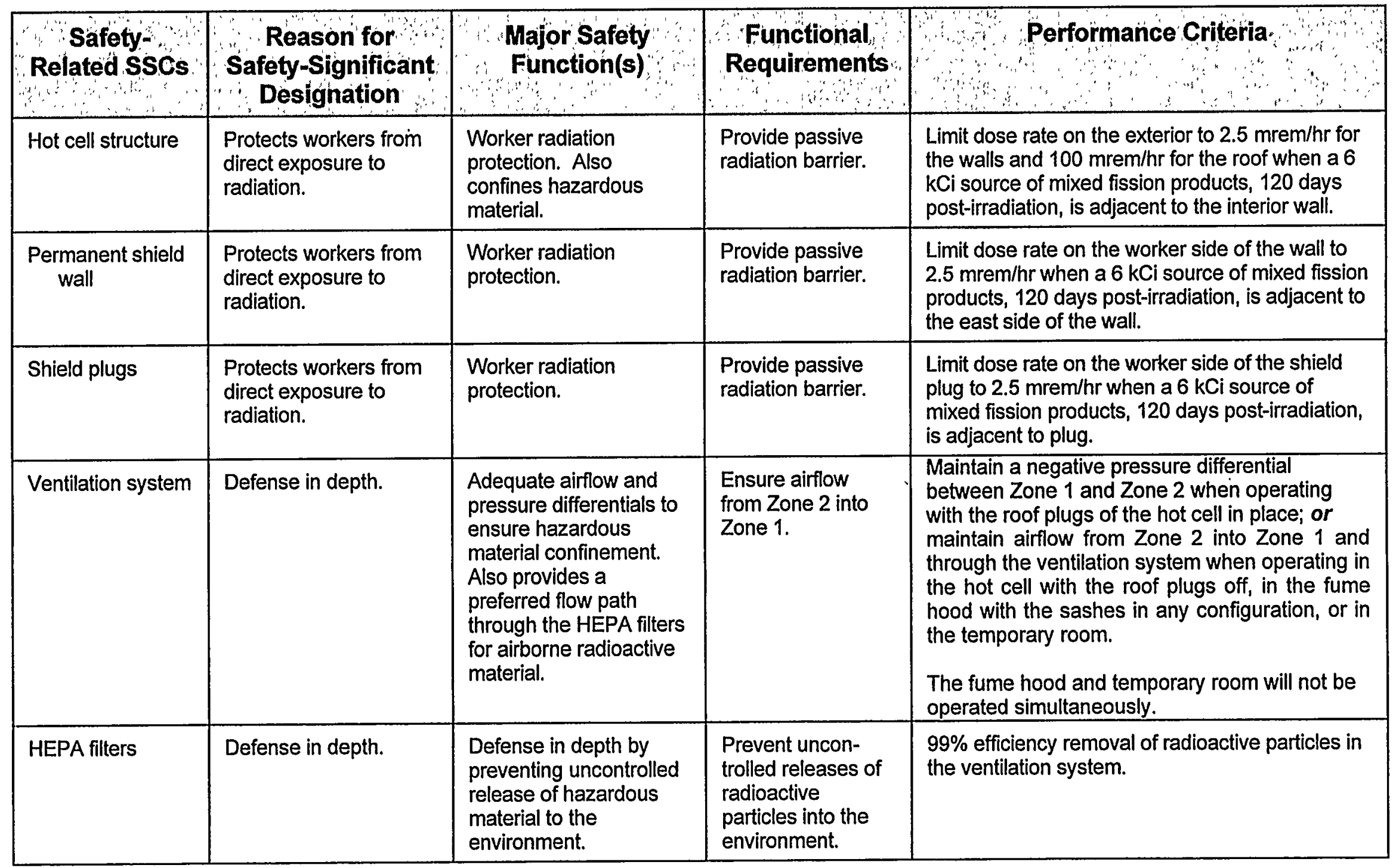


with galvanized sheet metal panels that serve as a liner to cover the surfaces and simplify decontamination.

The roof is of similar construction, with $30 \mathrm{~cm}$ (12 in.) of sand between 20-cm (8-in.) concrete panels. Two 91-cm (36-in.) plugs for the roof openings are removed to provide access to the hot cell.

These building structures are design features that perform passive safety functions.

\subsubsection{Functional Requirements}

The safety-related features of the major hot-cell structures are inherently passive: they provide passive shielding, confinement, and structural support. Thus, two functional requirements apply to the hot cell:

- To confine radioactive material (defense in depth).

- To provide radiation protection of workers from radioactive material operations during normal and abnormal conditions (worker safety).

Materials processing in the hot cell is discussed in detail in Sections 2.5.4 and 2.5.4.2.

\subsubsection{System Evaluation}

The design-basis accidents, operational accidents, and external events that could affect the AHCF major building structures are identified and analyzed in Chapter 3. Based on the results of these analyses, the confinement function of the shielding walls is provided by the physical integrity of the walls. The sufficiency of this physical integrity will be continually demonstrated and monitored by the presence of a pressure gradient across the wall when the ventilation system is operating and the roof plugs are in place.

The walls were designed to reduce the dose rate from a source of $6 \mathrm{kCi}$ mixed fission products, more than 120 day post-irradiation, located in the hot cell, to a level of 2.5 $\mathrm{mrem} / \mathrm{hr}$ at the exterior surface of the hot-cell walls. The ceiling is designed for a dose rate of $100 \mathrm{mrem} / \mathrm{hr}$ at the exterior surface. Access to the area above the hot cell will be administratively controlled. (Because the area above the hot cell is not inhabited, the dose rate criterion for the roof is less stringent than that for the walls, as discussed in Section 2.4.2.1.)

\subsubsection{Controls (TSRs)}

Hot cell structures provide inherently passive safety functions (i.e., confinement integrity, radiation shielding, and radioactive material confinement). The confinement integrity of the structures is verified by monitoring the existence of a pressure gradient between the hot cell and Building 6597 when the ventilation system is operating and shield plugs are in place. No TSRs are required; however, shielding attenuation will be measured prior to 
operation, and periodic radiation surveys will be performed to ensure that radiation shielding integrity is maintained.

\subsubsection{Permanent Shield Wall}

One permanent shield wall is planned for the AHCF. The wall will extend northward from the west wall of the hot cell. The area behind the permanent shield wall will be used for package characterization and handling in accordance with the decision process described in Section 2.5.4 and Figure 2-6.

\subsubsection{Safety Function}

The permanent shield wall provides worker radiation protection during waste package characterization and handling.

\subsubsection{System Description}

The permanent shield wall, adjacent to the hot cell, will be constructed of normal-density $\left(144 \mathrm{lb} / \mathrm{ft}^{3}\right)$ concrete. It will be $-91 \mathrm{~cm}(36 \mathrm{in}$.) thick, $3.7 \mathrm{~m}(12.0 \mathrm{ft})$ high, and $3 \mathrm{~m}(10 \mathrm{ft})$ wide. It will have a viewing window that is $76 \mathrm{~cm}(30$ in.) wide and $61 \mathrm{~cm}(24 \mathrm{in}$.) tall. CRL Model F master-slave manipulators will be positioned above and on each side of the viewing window to permit remote manipulation of containers. A detailed description of the permanent shield wall can be found in Section 2.4.2.3.

The area north of the hot cell and east of the permanent shield wall will be used for two purposes: (1) as a general staging area for work in the AHCF, and (2) as an area for handling packages that are unsuitable for the fume hood and too large to fit through the roof ports of the hot cell. The use of this area is discussed in detail in Sections 2.5.4 and 2.5.4.3.

\subsubsection{Functional Requirements}

The shield wall must provide radiation protection for workers while permitting the ability to remotely perform waste characterization tasks.

\subsubsection{System Evaluation}

The permanent shield wall was designed to reduce the dose rate from a $6 \mathrm{kCi}$ mixed fission product source to a maximum level of $2.5 \mathrm{mrem} / \mathrm{hr}$ at the wall surface on the worker side. It provides the same gamma attenuation as the hot-cell walls. The threat for worker exposure evaluated in Chapter 3 is more serious for material transfer up and into the hot cell than for characterization activities conducted behind the shield wall. Entry into the area north and east of the permanent shield wall and exposure to colocated workers will be controlled in accordance with the RPPM (SNL 1999). 


\subsubsection{Controls (TSRs)}

The permanent shield wall provides the passive safety function of radiation shielding. The properties of the shield wall are not expected to change; therefore, no TSRs are required to ensure its proper performance. However, shielding attenuation will be measured prior to operation.

\subsubsection{Shield Plugs}

Four 25.4-cm (10-in) inside diameter (ID), 4.6-m (15-ft)-deep floor silos and two 76.2$\mathrm{cm}$ (30-in.) ID, 4.6-m (15-ft)-deep floor silos will be located north of the hot cell and east of the permanent shield wall. One 76.2-cm (30-in.) and one 25.4-cm (10-in.) silo will be aligned on center with the viewing window in the permanent shield wall. Silos east of the permanent shield wall will have removable locking-type shield plugs and will be designed to deter the entry of water into the silo. The position of these silos is illustrated in Figure 2-2.

Two silos will also be placed in the hot cell. Inside silos will have covers that are flush with the floor; however, they do not need shield plugs. They only need lids strong enough to handle loads set upon them.

\subsubsection{Safety Function}

The shield plugs protect workers from radiation generated by radioactive packages stored in the floor silos.

The silos, separate from the shield plugs or hot-cell walls, do not perform any active or passive safety-significant function.

\subsubsection{System Description}

Silo and shield plug design is not final (see Section 2.4.2.5); the SAR for the AHCF will provide a final design. At this time, the AHCF project is evaluating a preliminary design as described in this section. The project is considering a consistent design criterion of 2.5 $\mathrm{mrem} / \mathrm{hr}$ with $6 \mathrm{kCi}$ of mixed fission products for the entire AHCF, including the hot cell walls and the permanent shield wall, as discussed above. The shield plugs for the silos behind the permanent shield wall will be designed to this level of protection.

\subsubsection{Functional Requirements}

The shield plugs must protect workers entering the area east of the shield wall from radiation generated by radioactive packages stored in the floor silos.

Although the shield plugs and concrete pad will be designed to deter the entry of water into the silos, this is not a functional requirement. Water in the silos is considered in the double-contingency criticality analysis. 


\subsubsection{System Evaluation}

The shield plugs will be designed to reduce the dose rate from a $6 \mathrm{kCi}$ mixed fission product source to a level of $2.5 \mathrm{mrem} / \mathrm{hr}$ at the surface of the plugs. The shield plugs will provide the same gamma attenuation as the hot-cell walls.

\subsubsection{Controls (TSRs)}

The shield plugs provide the passive safety function of radiation shielding. Source strength and location of sources in storage will be administratively controlled. The properties of the shield plugs are not expected to change; therefore, no TSRs are required to ensure their proper performance. However, shielding attenuation will be measured prior to operation.

\subsubsection{Ventilation System}

The ventilation system provides defense in depth and worker safety against the uncontrolled movement of radioactive material by establishing air leakage into the hot cell and airflow into the fume hood and temporary room, rather than out to the surrounding area. It also supports the function of the HEPA filters by providing a flow path through the filters for any airborne contaminants. A detailed description of the ventilation system is given in Section 2.6.4.

\subsubsection{Safety Function}

The overall safety-related function of the AHCF ventilation system is to provide a controlled, filtered path for all potential airborne radioactive material in the AHCF. This safety-related function ensures the confinement function of the hot cell by maintaining a negative pressure differential between the interior of the hot cell and Building 6597 when the roof plugs are in place to minimize airborne radioactive material movement between the areas. The ventilation system exhausts filtered air to the stack.

\subsubsection{System Description}

The exhaust system for Building 6597 (Zone 2) is separate from that of the hot cell, fume hood, and temporary room (Zone 1). The Zone 1 AHCF ventilation is a stand-alone system that does not tie into Building 6597 mechanical systems.

The Zone 1 ventilation system will have a design capability of exhausting at a variable rate of 1740 to $3360 \mathrm{acfm}$ for the fume hood, $700 \mathrm{acfm}$ for the hot cell, and $600 \mathrm{acfm}$ for a temporary room used for confinement as needed east of the permanent shield wall, through a two-stage HEPA filter train. The damper in the ventilation system for the fume hood and the temporary room prevent the two from being operated simultaneously. An administrative control will ensure that the fume hood and temporary room are not in use at the same time. An additional HEPA pre-filter will treat exhaust from the hot cell before it enters the main HEPA filter train. The exhaust system will be capable of 
maintaining adequate airflow from Zone 2 to Zone 1 through the fume hood and temporary room.

- A control system will be incorporated into the exhaust system design to allow selection of each of the three exhaust streams (hot cell alone; hot cell plus walk-in fume hood; or hot cell plus temporary room).

- The exhaust fan will discharge to a vertical exhaust stack. The duct work will be designed to support easy retrofit should equipment be needed later for continuousair stack monitoring for NESHAP compliance.

- The two-stage train will have fire screens, pre-filters, isolation dampers, backdraft dampers, and bag-in/out capability. The backdraft dampers will prevent reverse flow back into the hot cell, fume hood, or temporary room, which could spread contamination outside these areas. The fire screen will be located at least $6 \mathrm{~m}$ (20 ft) upstream of the HEPA filter.

- An alarm system will alert operators to unintentional shutdown.

- A make-up air system will operate during the heating season to make up air pulled out of the Building 6597 High Bay by the Zone 1 exhaust system.

\subsubsection{Functional Requirements}

The safety-related features of the AHCF ventilation system are in service during radioactive-material handling operations and consist mostly of passive components. The major active component of the system is the fan, which operates continuously when the hot cell, fume hood, or temporary room is in use to exhaust ventilation system effluents to the AHCF stack. The functional requirement applicable to the ventilation system is to maintain adequate airflow through the hot cell, fume hood, and temporary room or negative pressure differential, as appropriate.

\subsubsection{System Evaluation}

The ventilation system nominally maintains a design static pressure of 0.1 in. w.c. System exhaust capabilities are discussed in Section 2.6.4.

\subsubsection{Controls (TSRs)}

The ventilation system is not necessary to preclude exceeding the off-site evaluation guideline of $25 \mathrm{rem}$ (whole-body) during a radioactive material release accident; however, use of the system ensures that airflow is from Zone 2 into Zone 1 to minimize the spread of contamination. Worker radiological exposures during both normal and offnormal conditions are reduced by using the ventilation system. Therefore, operability of the ventilation system will be a Limiting Condition of Operation (LCO) for work in the hot cell, fume hood, and temporary room. 


\subsubsection{HEPA Filters}

By capturing particulate contamination in the filter medium, the HEPA filters provide defense in depth against the uncontrolled release of airborne radioactive material through the AHCF ventilation system. The HEPA filter train is described in more detail in Section 2.6.4 and illustrated in Figure 2-7.

\subsubsection{Safety Function}

The overall safety-related function of the HEPA filters is to filter the ventilation exhaust air to remove potential airborne radioactive material in the AHCF. This safety-related function reduces in-cell airborne radioactivity levels and minimizes the possible spread of contamination. In addition, the contamination level of potential discharges to the environment is reduced.

\subsubsection{System Description}

The HEPA filters are standard cartridge-type filters with bag in/bag out capability. The filters will be installed in a two-stage train for the AHCF. The HEPA filtration system is described in detail in Section 2.6.4 and briefly in Section 4.4.4.2.

\subsubsection{Functional Requirements}

The HEPA filters are in service during radioactive-material handling operations and are passive components. The functional requirement applicable to the HEPA filters is to provide two stages of particulate filtration (defense in depth).

\subsubsection{System Evaluation}

The HEPA filters will capture $>99 \%$ of the airborne particulate materials, as small as 0.3 micron, flowing through the ventilation system.

\subsubsection{Controls (TSRs)}

Although the HEPA filters are not required to meet the evaluation guidelines, filtering of potential airborne radioactive material under normal and abnormal conditions provides defense in depth for reducing releases to the environment. TSR surveillance monitoring of the filters will be required to ensure that adequate safety function performance is maintained under all operating conditions.

\subsection{REFERENCES}

(DOE 1996a)

U.S. Department of Energy, DOE Order 420.1, "Facility Safety," Chg. 2, U.S. Department of Energy, Washington, DC, October 24, 1996. 
(DOE 1996b)

(DOE 1994a)

(DOE 1994b)

(DOE 1993)

(SNL 1999)
U.S. Department of Energy, DOE Order 5480.22, "Technical Safety Requirements," Chg. 2, U.S. Department of Energy, Washington, DC, January 23, 1996.

U.S. Department of Energy, DOE-STD-3009-94, "Preparation Guide for U.S. Department of Energy Nonreactor Nuclear Facility Safety Analysis Reports," U.S. Department of Energy, Washington, DC, July 1994.

U.S. Department of Energy, DOE Order 5480.23, Chg. 1, "Nuclear Safety Analysis Reports," U.S. Department of Energy, Washington, DC, March 10, 1994.

U.S. Department of Energy, DOE-STD-1073, Parts 1 and 2, "Guide for Operational Configuration Management Program," U.S. Department of Energy, Washington, DC, November 1993.

Sandia National Laboratories, "Radiological Protection Procedures Manual," CPR400.1.1.32, Sandia National Laboratories, Albuquerque, New Mexico, January 21, 1999. 


\section{ChAPTER 5}

\section{DERIVATION OF TECHNICAL SAFETY REQUIREMENTS}

\section{$5.1 \quad$ INTRODUCTION}

The purpose of this chapter is to provide the bases for the TSRs for the AHCF. This information is intended to satisfy the requirements of DOE Order 5480.23, paragraph(s) 8.b.(3)(p). ${ }^{1}$ This chapter also includes information that will partially satisfy the requirements of DOE Order 5480.23, paragraph(s) 8.b.(3)(b), (f), and (u). ${ }^{2}$ The control functions determined to be essential in Chapters 3 and 4, which when implemented will ensure the safe operation of the AHCF, are the bases for the derivation of the TSRs. This chapter therefore provides the link between the assumptions made in the hazard/accident analysis, operational safety commitments, plant configuration, and the TSR document as required by the DOE (1992).

The following information is needed to derive the bases for the TSRs:

- Assumptions made in the hazard and accident analysis regarding prevention or mitigation of the consequences of postulated accident scenarios;

- Safety-significant features of the design and administrative controls documented in the PSAR; and

- Program commitments assumed to perform institutional safety functions, as documented throughout the PSAR, that will serve as input to the TSR administrative controls.

\subsection{REQUIREMENTS}

This section addresses the DOE orders required to establish the safety basis or operating envelope, that is, TSRs, for the AHCF. Only those requirements that are specific to this chapter and pertinent to the safety analysis are identified.

- DOE Order 5480.22, Technical Safety Requirements - This order and its attachment, "Guidelines for TSRs," establishes the requirement to prepare TSRs for all DOE nuclear facilities and delineates the criteria, content, format, approval process, and reporting requirements for TSRs and their revisions (DOE 1992).

\footnotetext{
As amplified in Attachment 1, paragraph(s) 4.f.(3)(d)16, of the Order (Topic 16).

2 As discussed in DOE-STD-3009-94 (DOE 1994a).
} 
- DOE Order 5480.21, Unreviewed Safety Questions - This order specifies the applicable conditions and basis for determining the existence of an unreviewed safety question (USQ) for proposed changes or modifications to the facility design or operation (DOE 1991). Implementation of this order requires consideration of whether a proposed activity may raise a conflict with the facility TSRs.

- DOE Order 5480.23, Nuclear Safety Analysis Reports - This order requires nuclear facilities to document the safety analyses that establish the adequacy of the facility safety bases (DOE 1994b). A SAR documents the results of the safety analysis for the facility. The SAR must address the derivation of TSRs (as indicated in Section 8 under Requirements, Part $b$, subsection (p)). The attachment to the order, "Interim Guidance for DOE Order 5480.23 - SARs," Section 4, Interpretation, Part $f$, Subsection d.16, provides additional guidance on content.

- DOE Order 420.1, Facility Safety - This order specifies the basic nuclear facility safety program requirements, including nuclear and explosives safety, fire protection, nuclear criticality safety, and natural phenomena hazards mitigation (DOE 1996).

- DOE-STD-3009-94, Preparation Guide for U.S. Department of Energy Nonreactor Nuclear Facility Safety Analysis Reports - This standard includes guidance for preparation of this chapter of the PSAR (DOE 1994a).

- DOE-STD-1027-92, Change Notice 1, "Hazard Categorization and Accident Analysis Techniques for Compliance with DOE Order 5480.23, Nuclear Safety Analysis Reports" - This standard provides guidance for determining hazard categorization and performing accident analysis for SARs (DOE 1997).

\subsection{TSR COVERAGE}

This section summarizes all SSCs and administrative controls that are identified in Chapters 3 and 4 as necessary for providing safety-significant defense in depth or worker safety because they either reduce the likelihood of an accident, mitigate the consequences of an accident, or protect the environment.

No unmitigated accident scenario will result in radiological exposures at the exclusion area boundary that will approaich the off-site evaluation guideline of $25 \mathrm{rem}$ (see Chapter 3). Therefore, no safety-class SSCs are required to maintain the consequences of facility operations below the evaluation guidelines. As a result, no TSR Safety Limits (SLs) or Limiting Control Settings (LCSs) are required for AHCF SSCs. Section 4.4 addresses those SSCs that perform a safety-significant defense in depth or worker safety function. These safety-significant SSCs are summarized in Table 4-1. 
DOE (1992) has set the following criteria for determining the applicability of TSR limiting conditions for operation (LCOs) to safety-related SSCs. These criteria were used to ensure that the list of safety-significant SSCs contained in Table 4-1 is complete.

Criterion 1: Installed instrumentation that is used to detect and indicate (in a control room or other control location) a significant degradation of the physical barriers that prevent an uncontrolled release of radioactive materials.

Criterion 2: SSCs that are relied upon in the safety analyses to function/actuate to prevent or mitigate accidents or transients that involve the assumed failure of, or present a challenge to, the integrity of a physical barrier that prevents the uncontrolled release of radioactive materials.

Criterion 3: Process variables that are initial conditions for those design basis accidents or transient analyses that involve the assumed failure of, or present a challenge to, the integrity of a radioactive material barrier.

Criterion 4: Experiments and experimental facilities that could provide a path for the uncontrolled release of hazardous materials.

Criterion 5: Systems and equipment that are used for handling fissile material.

Criterion 1 applies to the AHCF ventilation instrumentation that measures airflow and differential pressure because they provide a direct indication of Zone 1 confinementbarrier integrity. These physical barriers are required to prevent uncontrolled releases of radioactive materials under normal and abnormal conditions.

Criterion 2 applies to the Zone 1 confinement structures, the Zone 1 ventilation system, and the HEPA filters. These SSCs constitute the physical barriers that prevent the uncontrolled release of radioactive materials from the AHCF during normal and abnormal operating conditions. Thus, these items provide defense in depth or protect the worker.

Criterion 3 is not applicable. The ventilation system airflow and differential pressure are barriers to the movement of radioactive contamination between zones under normal and abnormal conditions, but failure to maintain them does not initiate any design basis accident with the potential for an uncontrolled release of radioactive materials.

Criterion 4 does not apply to waste and material characterization, treatment, or repackaging. Criterion 4 must be applied on a case-by-case basis by means of the USQ process as "experimental conditions" are proposed (DOE 1991).

Criterion 5 will be applied through the Criticality Safety Program as implemented in the AHCF. Fissile material inventories presented for repackaging may require a packagespecific CSA. 
Table 5-1. TSR Coverage Summary

\begin{tabular}{|l|l|l|l|}
\hline $\begin{array}{l}\text { Systems, } \\
\text { Structures, or } \\
\text { Components }\end{array}$ & $\begin{array}{l}\text { Safety Function } \\
\text { Coverage }\end{array}$ & Required? & \\
\hline Hot cell structure & Worker safety & No & $\begin{array}{l}\text { No TSR required: Design } \\
\text { feature needs acceptance } \\
\text { testing only. }\end{array}$ \\
\hline Permanent shield wall & Worker safety & No & $\begin{array}{l}\text { No TSR required: Design } \\
\text { feature needs acceptance } \\
\text { testing only. }\end{array}$ \\
\hline Shield plugs & Worker safety & No & $\begin{array}{l}\text { No TSR required: Design } \\
\text { feature needs acceptance } \\
\text { testing only. }\end{array}$ \\
\hline Ventilation system & Defense in depth & Yes & LCO, Surveillance requirement \\
\hline HEPA filters & Defense in depth & Yes & LCO, Surveillance requirement \\
\hline $\begin{array}{l}\text { Other } \\
\text { Commitments }\end{array}$ & Worker safety & No & $\begin{array}{l}\text { No TSR required: Design } \\
\text { feature needs acceptance } \\
\text { testing only. }\end{array}$ \\
\hline $\begin{array}{l}\text { Silos behind } \\
\text { permanent shield wall }\end{array}$ & Yes & Administrative control \\
\hline $\begin{array}{l}\text { Radioactive material } \\
\text { limits }\end{array}$ & $\begin{array}{l}\text { Worker safetyl } \\
\text { Defense in depth }\end{array}$ & Yes & Administrative control \\
\hline $\begin{array}{l}\text { Flammable material } \\
\text { limits }\end{array}$ & Worker safety & Yes. & Administrative control \\
\hline $\begin{array}{l}\text { Worker access } \\
\text { controls }\end{array}$ & Worker safety & & \\
\hline
\end{tabular}

Worker protection from radiation under normal and abnormal operating conditions at the AHCF is provided by means of passive engineered barriers and access controls. Protection from hazardous materials under abnormal and accident conditions is provided by hazardous material inventory limits and appropriate worker safety programs. The administrative controls identified in Chapter 3 perform significant safety functions (either worker safety or defense in depth) in mitigating potential accident consequences. Thus, specific hazardous material inventory limits and applicable worker safety program controls are specified in the TSR as administrative controls. Table 5-1 summarizes the type of TSR coverage associated with each of the items addressed above.

\subsection{DERIVATION OF FACILITY MODES}

Operational modes are used to categorize the requirements placed on the AHCF as a convenience for management control. Operational modes are also used in the TSRs to clearly define operational condition boundaries and to establish facility status. They define equipment operability requirements and allowable actions by operations personnel 
under normal, abnormal, and accident conditions. More specifically, modes are used to define the applicability of the actions or conditions specified by the TSR limits.

Four operational modes are used to encompass all operating conditions for the hot cell, fume hood, and temporary room:

- Operation,

- Standby,

- Maintenance, and

- Shutdown.

Table 5-2 lists these modes and their definitions (with respect to allowable facility conditions) in descending order of safety significance, that is, from the highest risk mode (operation) to the safest mode (shutdown). When there is no threat of contamination, many activities-including transport, packaging, sorting, etc.-may be performed safely in Zone 2 without the Zone-1 ventilation system operating or operable. Such activities may take place in Operation, Standby, or Maintenance modes.

The Operation, Standby, Maintenance, and Shutdown modes apply only to the hot cell, fume hood, and temporary room, which are the only AHCF structures attached to the Zone-1 ventilation system. These modes do not apply to the silos behind the permanent . shield wall, because these silos are operational independently of the status of the Zone-1 ventilation system. The modes do not apply to activities that present no contamination hazard, for example, moving packages into and out of the silos behind the permanent shield wall. These activities may take place regardless of the status of the ventilation system. In no case will movement of materials take place in such a way as to exceed the Category 2 threshold quantities in any segment.

\subsection{TSR DERIVATION}

This section derives the AHCF TSRs. Because of the Hazard Category 3 classification of the AHCF and the results of the accident analysis, no safety-class SSCs have been identified. Because no SSCs are needed to maintain off-site consequences within the 25 rem evaluation guideline, the TSRs consist of LCOs, Surveillance Requirements, and Administrative Controls (Table 5-1). The modes defined in Table 5-2 apply only to the hot cell, fume hood, and temporary room, which are the only AHCF structures attached to the Zone-1 ventilation system. These are the only structures to which LCOs apply.

\subsubsection{Ventilation System}

The ventilation system provides a primary confinement barrier for radioactive particles in the AHCF. During waste- and material-handling operations, the ventilation system ensures that either Zone 1 is kept at a lower pressure than Zone 2 to minimize the spread of radioactive material to Zone 2, or that adequate airflow is maintained to provide 
Table 5-2. AHCF Mode Definitions*

\begin{tabular}{|c|c|c|c|c|}
\hline \multirow{2}{*}{$\begin{array}{l}\text { Status or } \\
\text { Condition }\end{array}$} & \multicolumn{4}{|c|}{ Mode } \\
\hline & Operation & Standby & Máintenance & Shutdowin \\
\hline Operations & $\begin{array}{l}\text { Normal activities are being } \\
\text { performed, including } \\
\text { movement, treatment, and } \\
\text { repackaging of waste and } \\
\text { materials. }\end{array}$ & $\begin{array}{l}\text { Waste- and material- } \\
\text { processing activities are not } \\
\text { permitted; movement of } \\
\text { radiological materials is not } \\
\text { permitted, except for } \\
\text { changing to a safer } \\
\text { configuration. }\end{array}$ & $\begin{array}{l}\text { Waste- and material- } \\
\text { processing activities are not } \\
\text { permitted; movement of } \\
\text { radiological materials is not } \\
\text { permitted, except for } \\
\text { changing to a safer } \\
\text { configuration. }\end{array}$ & $\begin{array}{l}\text { No operations } \\
\text { activities are } \\
\text { permitted. }\end{array}$ \\
\hline Material Locations & $\begin{array}{l}\text { Radioactive and hazardous } \\
\text { materials may be located in all } \\
\text { areas of the facility as } \\
\text { described in the PSAR. }\end{array}$ & $\begin{array}{l}\text { Radioactive and hazardous } \\
\text { materials may be located in } \\
\text { all areas of the facility as } \\
\text { described in the PSAR. }\end{array}$ & $\begin{array}{l}\text { To the maximum extent } \\
\text { possible, radioactive and } \\
\text { hazardous materials have } \\
\text { been removed from any area } \\
\text { undergoing maintenance. }\end{array}$ & $\begin{array}{l}\text { Radioactive and } \\
\text { hazardous materials } \\
\text { have been placed in } \\
\text { a safe configuration. }\end{array}$ \\
\hline Equipment Status & $\begin{array}{l}\text { Essential ventilation system } \\
\text { equipment is in service and } \\
\text { operating. }\end{array}$ & $\begin{array}{l}\text { Essential ventilation system } \\
\text { equipment is operable. }\end{array}$ & No requirement. & No requirement. \\
\hline
\end{tabular}

* Modes apply only to the hot cell, fume hood, and temporary room, which are the only AHCF structures attached to the Zone-1 ventilation system. Modes do not apply to the silos. Activities that present no contamination hazard may take place in Operation, Standby, and Maintenance modes regardless of the status of the ventilation system. 
airflow from Zone 2 into Zone 1. Operation of the ventilation system is not a prerequisite for activities outside the hot cell, fume hood, or temporary room that do not present a contamination hazard. The fume hood and temporary. room will not be used simultaneously, because the Zone-1 ventilation system can serve only one at a time (see Section 2.6.4).

\subsubsection{Safety Limits, Limiting Control Settings, and Limiting Conditions for Operation}

No SLs or LCSs are associated with Zone 1 confinement structures. However, because Zone 1 provides defense in depth against uncontrolled radioactive material releases, the following LCOs are established:

- A negative pressure differential must be maintained between Zone 1 and Zone 2 when operating with the roof plugs of the hot cell in place; or

- Airflow from Zone 2 into Zone 1 and through the ventilation system must be maintained when operating in the hot cell with the roof plugs off, in the fume hood with the sashes in any configuration, or in the temporary room.

\subsubsection{Surveillance Requirements}

Differential pressure or airflow must be monitored during all operations. To ensure the appropriate differential pressure or airflow is maintained during operations in the closed hot cell, measurement instrumentation must be checked and calibrated periodically to verify operability. Differential pressure is not expected to be measurable when the hot cell roof plugs are not in place; airflow will be monitored during operations in the fume hood, the temporary room, and open hot cell.

\subsubsection{Administrative Controls}

No administrative controls are associated with maintaining Zone 1 integrity.

\subsubsection{HEPA Filtration System}

The AHCF HEPA filtration system provides a controlled, filtered path for radioactive particulate releases from the AHCF stack during normal and abnormal operating conditions. Ventilation system flow rates maintain negative Zone 1-to-Zone 2 differential pressures or adequate airflow to ensure the integrity of Zone 1 radioactive material confinement boundaries. When the ventilation system is operating, most radioactive particulate matter in the exhaust air is removed by HEPA filtration. When the ventilation system is not operating, operations are not permitted in the fume hood, temporary room, or hot cell. Operations that do not present a contamination hazard may be performed in Zone 2 regardless of the status of the ventilation system. 


\subsubsection{Safety Limits, Limiting Control Settings, and Limiting Conditions for Operation}

As indicated in Section 5.3, no SLs or LCSs are associated with the HEPA filtration systems because the filters are not safety class. However, because this system provides defense in depth against off-site radioactive material releases during normal and abnormal operating conditions, the following LCO is established for the operation mode (see Tables 5-1 and 5-2):

- A HEPA filter is in service.

\subsubsection{Surveillance Requirements}

The pressure drop across the in-service HEPA filter must be checked periodically to ensure continued performance capability. Periodic in-place testing of HEPA filters must be performed to verify filter efficiency.

\subsubsection{Administrative Controls}

No administrative controls are required.

\subsubsection{Radioactive Material Limits}

Limits on radioactive material inventories are established by administrative controls. These limits are in effect for all modes.

\subsubsection{Safety Limits, Limiting Control Settings, and Limiting Condition for Operation}

No SLs, LCSs, or LCOs are associated with maintaining inventories below Category 2 threshold radioactive material limits.

\subsubsection{Surveillance Requirements}

This section is not applicable, because there are no SLs, LCSs, or LCOs for maintaining inventories below Category 2 threshold radioactive material limits.

\subsubsection{Administrative Controls}

Administrative controls will maintain the total radioactive material inventory within each storage silo and the combined hot cell and Building 6597 High Bay below the Hazard Category 2 threshold levels (DOE 1997), or $6 \mathrm{kCi}$ of mixed fission products more than 120 days post-irradiation, whichever is more limiting.

Fissile material limits, if any, will be outlined in the AHCF or package-specific Criticality Safety Assessments. 


\subsubsection{Flammable Material Limits}

To reduce the potential for fires, the quantity of flammable or combustible material introduced into the hot cell during waste and material processing is limited to levels below the UBC 1997 thresholds for unsprinkled areas (ICBO 1997). The quantity of flammable or combustible material in the High Bay is limited to levels below the UBC 1997 thresholds for sprinkled areas (ICBO 1997).

\subsubsection{Safety Limits, Limiting Control Settings, and Limiting Conditions for Operation}

No SLs, LCSs, or LCOs are associated with flammable or combustible materials.

\subsubsection{Surveillance Requirements}

This section is not applicable, because there are no SLs, LCSs, or LCOs for flammable or combustible materials.

\subsubsection{Administrative Controls}

The quantity of flammable or combustible material allowed in the hot cell will be limited to quantities allowed by the UBC for H-7 unsprinkled areas (ICBO 1997).

\subsubsection{Worker Access Controls}

The area above the hot cell is not inhabited; therefore, the dose rate criterion for the roof is less stringent than that for the walls $(100 \mathrm{mrem} / \mathrm{hr}$ as compared to $2.5 \mathrm{mrem} / \mathrm{hr})$. To limit the potential for worker exposure, access to the hot-cell roof will be limited whenever a significant source is present in the hot cell.

Access to the exterior of Building 6597 will be controlled during in-air transfers of exposed radioactive sources.

\subsubsection{Safety Limits, Limiting Control Settings, and Limiting Conditions for Operation}

No SLs, LCSs, or LCOs are associated with worker access to the hot-cell roof.

\subsubsection{Surveillance Requirements}

This section is not applicable, because there are no SLs, LCSs, or LCOs for worker access to the hot-cell roof. 


\subsubsection{Administrative Controls}

Worker access to the hot-cell roof will be controlled when a significant radiation source is present in the hot cell. Worker access to the exterior of the building will be controlled during in-air transfers of exposed sources.

\subsubsection{Other Administrative Controls}

Other administrative controls that may not have been explicitly identified in the hazard or accident analysis include management commitments to establish, implement, and maintain appropriate controls and activities that provide additional defense-in-depth safety. Table 5-3 summarizes the controls required to be in place within the AHCF.

\subsection{DESIGN FEATURES}

This section identifies those design features from the hazard or accident analysis that are considered passive in nature but provide a safety function to either prevent or mitigate the consequences of postulated accident scenarios.

\subsubsection{Fire Prevention and Mitigation Features}

The construction materials used in the High Bay and hot cell are noncombustible (see Chapter 2). Construction features that aid in fire prevention include the following:

- CMU High-Bay walls set between cast-in-place concrete columns,

- Building 6597 metal overhead coiling (rollup) doors with hollow metal frames,

- Building 6597 sprinkler system,

- Hot cell walls constructed of inner and outer precast, reinforced concrete panels separated by a space filled with common construction-grade sand,

- Hot cell roof constructed of precast concrete roof panels, and

- Hot cell inserts for manual fire suppression equipment, if required.

These design features provide adequate fire protection for the AHCF.

\subsubsection{Radiation Shielding Features}

As described in Chapter 2, the hot cell, the permanent shield wall, and the shield plugs provide radiation shielding for facility workers. Most AHCF operations requiring remote handling of radioactive material will be performed in the hot cell. Construction features that aid in radiation shielding include the following: 
Table 5-3. AHCF Administrative Control Summary

\begin{tabular}{|c|c|}
\hline $\begin{array}{l}\text { Control } \\
\text { Fúnction }\end{array}$ & Control Description \\
\hline Fire Protection & $\begin{array}{l}\text { Flammable and combustible material control. } \\
\text { Control of ignition sources. } \\
\text { Fire fighting capabilities. } \\
\text { Emergency response (fires). } \\
\text { Fire department availability. } \\
\text { Fire protection assessment. } \\
\text { Automatic detection, alarm system operability, and manual suppression. } \\
\text { Proper availability and maintenance of fire fighting equipment. }\end{array}$ \\
\hline $\begin{array}{l}\text { Nuclear Criticality } \\
\text { Safety }\end{array}$ & $\begin{array}{l}\text { Fissile material inventories and posting. } \\
\text { Oversight by safety committees. } \\
\text { Spacing and storage of fissile material. } \\
\text { Nuclear Criticality Safety Analyses. }\end{array}$ \\
\hline Radiation Protection & $\begin{array}{l}\text { Radiological monitoring. } \\
\text { Radiation exposure control. } \\
\text { ALARA program. } \\
\text { Radiological protection training. } \\
\text { Radiological protection instrumentation. } \\
\text { Radiological protection record keeping. }\end{array}$ \\
\hline $\begin{array}{l}\text { Hazardous Material } \\
\text { Protection }\end{array}$ & $\begin{array}{l}\text { Hazardous material control. } \\
\text { ALARA program. }\end{array}$ \\
\hline $\begin{array}{l}\text { Qualification and } \\
\text { Training }\end{array}$ & $\begin{array}{l}\text { Training of AHCF staff personnel. } \\
\text { Training of radiation workers and other personnel with access to the } \\
\text { AHCF. }\end{array}$ \\
\hline $\begin{array}{l}\text { Review, Audits, and } \\
\text { Approvals }\end{array}$ & $\begin{array}{l}\text { Review of the following: } \\
\text { - PSAR, TSRs, and changes thereto; } \\
\text { - } \quad \text { tests and experiments; } \\
\text { - } \text { operating procedures and changes thereto; } \\
\text { - AHCF changes and modifications; } \\
\text { - maintenance and testing activities; } \\
\text { - conduct of operations; and } \\
\text { - operational abnormalities and occurrence reports. }\end{array}$ \\
\hline Waste Management & Monitoring and control of waste streams. \\
\hline Initial Testing & Verification of safety-significant SSC functionality. \\
\hline $\begin{array}{l}\text { In-Service } \\
\text { Surveillance }\end{array}$ & Verification of safety-significant SSC operability. \\
\hline Maintenance & $\begin{array}{l}\text { Maintenance of safety-related SSC operability. } \\
\text { Specification of schedules, procedures, and training requirements for } \\
\text { equipment maintenance. }\end{array}$ \\
\hline
\end{tabular}


Table 5-3. AHCF Administrative Control Summary (continued)

\begin{tabular}{|c|c|}
\hline $\begin{array}{l}\text { Control } \\
\text { Function }\end{array}$ & Control Description \\
\hline $\begin{array}{l}\text { Emergency } \\
\text { Preparedness }\end{array}$ & $\begin{array}{l}\text { - Emergency response organization. } \\
\text { - Emergency notification. } \\
\text { - Emergency facilities and equipment. } \\
\text { - Training and drills/exercise. } \\
\text { - Protective actions. }\end{array}$ \\
\hline Quality Assurance & $\begin{array}{l}\text { - Implemented throughout the AHCF for all safety-related SSCs and } \\
\text { programs. }\end{array}$ \\
\hline Record Keeping & - Maintenance of AHCF operating records. \\
\hline Configuration Control & $\begin{array}{l}\text { - Identification, documentation, and maintenance of technical baseline } \\
\text { for SSCs. }\end{array}$ \\
\hline $\begin{array}{l}\text { Unreviewed Safety } \\
\text { Question }\end{array}$ & $\begin{array}{l}\text { - USQ determination for proposed changes to facility, procedures, and } \\
\text { operational controls. }\end{array}$ \\
\hline Procedures & - Development and maintenance of procedures. \\
\hline
\end{tabular}

- Hot cell and permanent shield walls constructed to attenuate transmittance,

- Offset panel joints to prevent radiation streaming through the shield wall,

- Access penetrations in the walls designed with serpentine geometry to reduce streaming,

- Raised floor to prevent streaming under the wall panels,

- Steel plates at window frames to prevent streaming around the edges,

- No access ports for worker entry in the hot cell walls, and

- Shield plugs for the silos behind the permanent shield wall.

Neither the hot-cell silos nor the silos behind the permanent shield wall are safety significant. Rather, the hot cell and the shield plugs ensure worker safety by providing radiation shielding. Silos will be designed in accordance with SNL's RPPM and ALARA principles.

\subsection{INTERFACE WITH TSRS FROM OTHER FACILITIES}

The only TSRs from other facilities that affect the AHCF are those related to emergency preparedness, since the emergency evacuation and response program affects all the facilities located within Technical Area V. An emergency evacuation of any of the facilities within the TA-V will result in evacuation of all AHCF personnel. 


\subsection{REFERENCES}

(DOE 1997)

(DOE 1996)

(DOE 1994a)

(DOE 1994b)

(DOE 1992)

(DOE 1991)

(ICBO 1997)
U.S. Department of Energy, DOE-STD-1027-92, "Hazard Categorization and Accident Analysis Techniques for Compliance with DOE Order 5480.23, Nuclear Safety Analysis Reports," Change Notice No. 1, U.S. Department of Energy, Washington, DC, 1997.

U.S. Department of Energy, DOE Order 420.1, Facility Safety, Chg. 2, U.S. Department of Energy, Washington, DC, October 24, 1996.

U.S. Department of Energy, DOE-STD-3009-94, Preparation Guide for U.S. Department of Energy Nonreactor Nuclear Facility Safety Analysis Reports, U.S. Department of Energy, Washington, DC, July 1994.

U.S. Department of Energy, DOE Order 5480.23, Chg. 1, Nuclear Safety Analysis Reports, U.S. Department of Energy, Washington, DC, March 10, 1994.

U.S. Department of Energy, DOE Order 5480.22, Technical Safety Requirements, U.S. Department of Energy, Washington, DC, February 25, 1992.

U.S. Department of Energy, DOE Order 5480.21, Unreviewed Safety Questions, U.S. Department of Energy, Washington, DC, December 24, 1991.

International Conference of Building Officials, "1997 Uniform Building Code," International Conference of Building Officials, Whittier, CA, April 1997. 


\section{APPENDIX 3-A}

\section{Preliminary Hazard AsSessment}

The PHA for the AHCF is used to outline the accidents that might lead to release of hazardous materials and resulting exposure of workers or the public. The contributing events that could lead to these accidents are delineated. The design and operational features necessary to prevent contributing events from occurring are listed independently and then summarized under "Needs." Many of the mitigation and prevention features apply to all of the contributing events; the table indicates which features these are. If the number of an initiating event is specified in the "Prevention" or "Mitigation" column, it indicates that the measure is applicable to that event only. Although the tables explicitly consider only accidents in the High Bay or hot cell, the consequences of accidents involving any one of the silos east of the permanent shield wall are bounded by these accidents in the High Bay or hot cell.

The probability that each contributing event will occur is given in Appendix 3-B. The bases for the probability estimates is also presented there.

\section{REFERENCE}

(CFR 1998)

Code of Federal Regulations, "Occupational Safety and Health Standards," Title 29, Part 1910.119, Office of the Federal Register, National Archives and Records Administration, Washington, DC, July 1, 1998. 


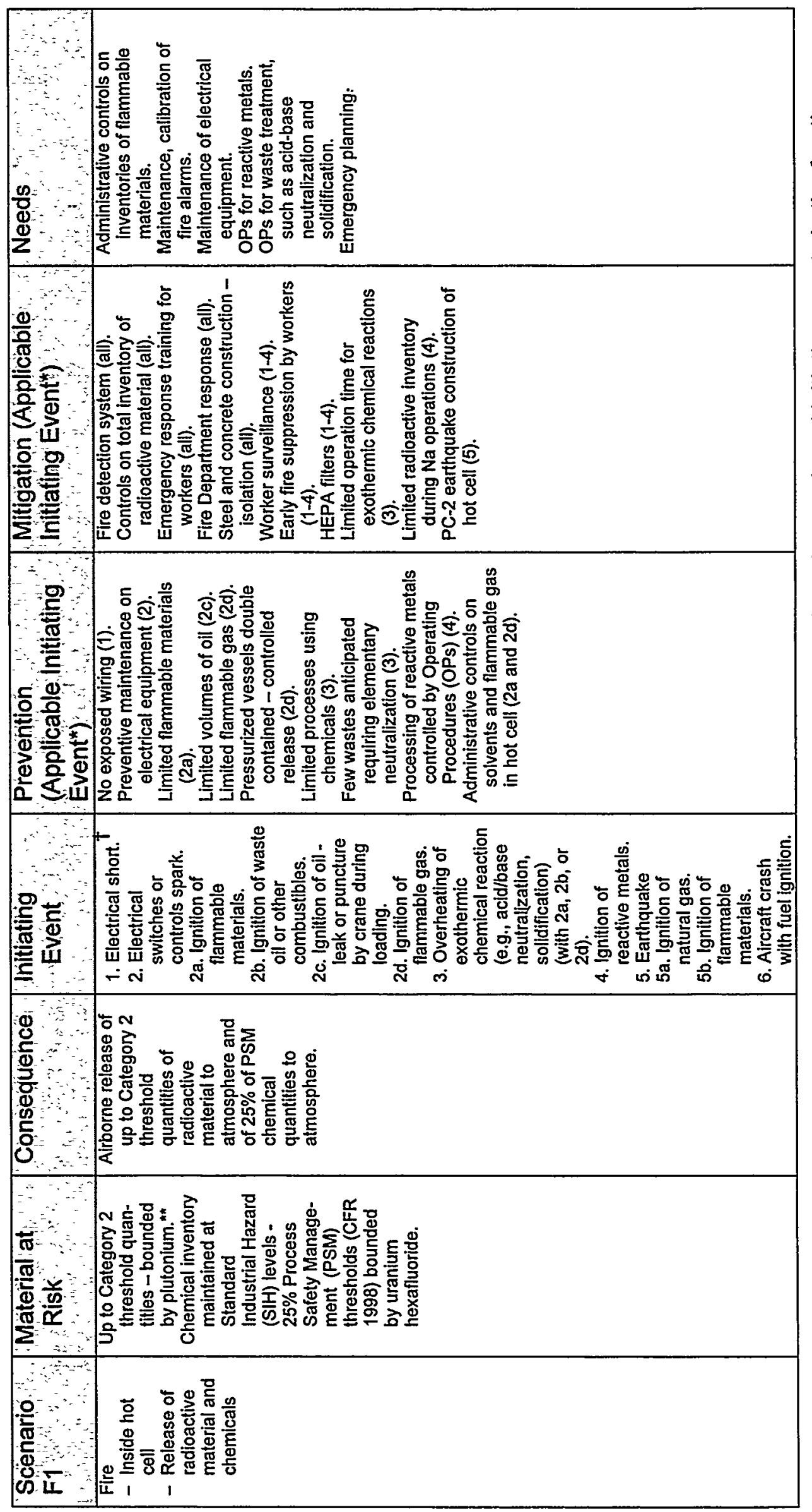

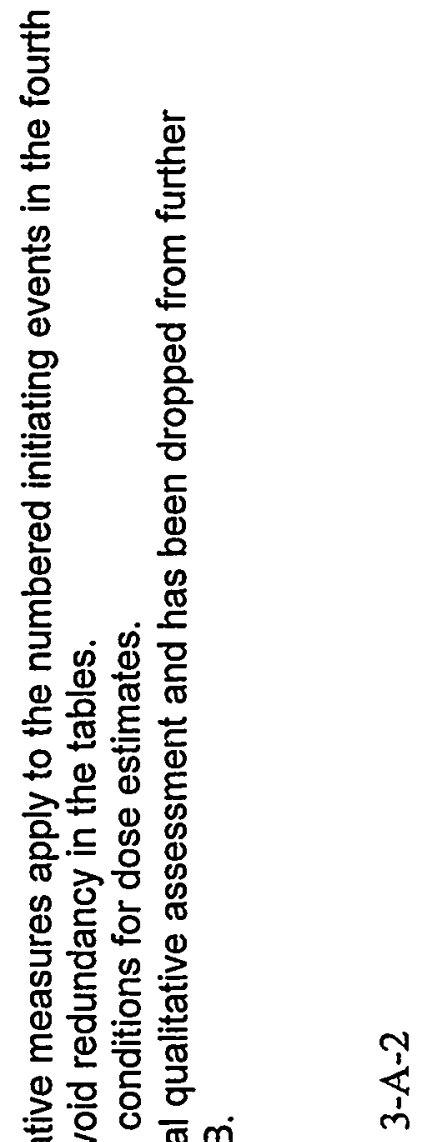




\begin{tabular}{|c|c|c|c|c|c|c|}
\hline $\begin{array}{l}\text { Scenario } \\
\text { F2 }\end{array}$ & $\begin{array}{l}\text { Material at } \\
\text { Risk }\end{array}$ & $\begin{array}{l}\text { Consequence } \\
\therefore \\
\therefore\end{array}$ & $\begin{array}{l}\text { Initiating } \\
\text { Event }\end{array}$ & $\begin{array}{l}\text { Prevention } \\
\text { (Applicable Initiating } \\
\text { Event) }\end{array}$ & $\begin{array}{l}\text { Mitigation (Applicable } \\
\text { Initiating Event) }\end{array}$ & $\begin{array}{c}\text { Needs } \\
\therefore \\
\therefore\end{array}$ \\
\hline $\begin{array}{l}\text { Fire } \\
\text { - Outside hot } \\
\text { cell } \\
\text { - Release of } \\
\text { radioactive } \\
\text { material and } \\
\text { chemicals }\end{array}$ & $\begin{array}{l}\text { Up to Category } 2 \\
\text { threshold } \\
\text { inventory - } \\
\text { bounded by } \\
\text { plutonium (multi- } \\
\text { drum event). } \\
\text { Chemical inventory } \\
\text { maintained at } \\
\text { SIH levels - } 25 \% \\
\text { of PSM } \\
\text { thresholds - } \\
\text { bounded by } \\
\text { uranium } \\
\text { hexafluoride. }\end{array}$ & $\begin{array}{l}\text { Airborne release of } \\
\text { up to Category } 2 \\
\text { threshold } \\
\text { quantities of } \\
\text { radioactive } \\
\text { material to } \\
\text { atmosphere and } \\
\text { of } 25 \% \text { of PSM } \\
\text { (CFR 1998) } \\
\text { chemical } \\
\text { quantities to } \\
\text { atmosphere. }\end{array}$ & $\begin{array}{l}\text { 1. Electrical short. } \\
\text { 2. Electrical } \\
\text { switches or } \\
\text { controls spark. } \\
\text { 2a. Ignition of a } \\
\text { large spill of } \\
\text { flammable } \\
\text { materials due to } \\
\text { major package } \\
\text { mishandling or } \\
\text { package leak. } \\
\text { 3. Ignition from } \\
\text { equipment mal- } \\
\text { function, e.g., } \\
\text { catastrophic } \\
\text { battery failure or } \\
\text { leaking of } \\
\text { hydraulic brake } \\
\text { fluid onto hot } \\
\text { brake surface- } \\
\text { when forklift } \\
\text { moves package. } \\
\text { 4. Earthquake. } \\
\text { 4a. Ignilion of } \\
\text { natural gas. } \\
\text { 4b. Ignition of flam- } \\
\text { mable material. } \\
\text { 5. Aircraft crash } \\
\text { with fuel ignition. }\end{array}$ & $\begin{array}{l}\text { Strong, tight packaging (all). } \\
\text { Limited chemical inventory in } \\
\text { building (2a). } \\
\text { All flammable material } \\
\text { appropriately stored (2a). } \\
\text { Visual surveillance of } \\
\text { packages by workers (2a). } \\
\text { Forklift training (2a). }\end{array}$ & $\begin{array}{l}\text { Emergency response training for } \\
\text { workers (all). } \\
\text { Controls on total inventory of } \\
\text { radioactive material (all). } \\
\text { Fire Department response (all). } \\
\text { Fire detection systems }(1,2) \text {. } \\
\text { Worker surveillance }(1,2) \text {. } \\
\text { Early fire suppression by workers } \\
(1,2) \text {. } \\
\text { Bullding fire suppression system } \\
(1,2) \text {. }\end{array}$ & $\begin{array}{l}\text { Electrical equipment } \\
\text { maintenance. } \\
\text { Forklift training. } \\
\text { Administrative controls on } \\
\text { total inventory of } \\
\text { radioactive material. } \\
\text { Administrative controls on } \\
\text { inventories of flammable } \\
\text { materials. } \\
\text { OP on material movement } \\
\text { and storage. } \\
\text { Emergency planning. } \\
\text { Rigging and hoisting training } \\
\text { for crane operators. }\end{array}$ \\
\hline
\end{tabular}

tThis event is considered to be implausible on the basis of initial qualitative assessment and has been dropped from further consideration. It is not carried into the analysis in Appendix 3-B. 


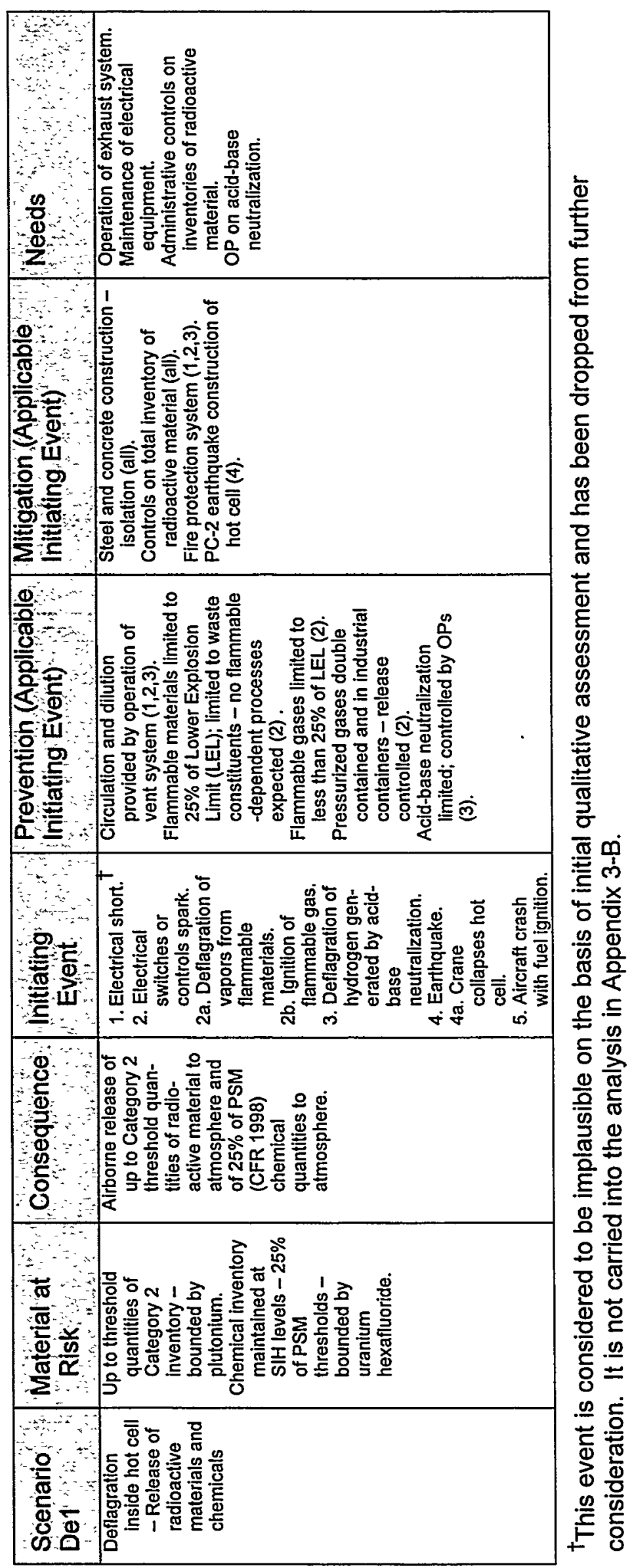

$\underset{\substack{+⿱ 亠 䒑}}{n}$ 


\begin{tabular}{|c|c|c|c|c|c|c|}
\hline $\begin{array}{l}\text { Scenario } \\
\text { De2 }\end{array}$ & $\begin{array}{l}\text { Material at } \\
\text { Risk }\end{array}$ & $\begin{array}{c}\text { Consequence } \\
\vdots\end{array}$ & $\begin{array}{l}\text { Initiating } \\
\text { Event }\end{array}$ & $\begin{array}{l}\text { Prevention (Applicable } \\
\text { Initiating Event) }\end{array}$ & $\begin{array}{l}\text { Mitigation (Applicable } \\
\text { Initiating Evènt) }\end{array}$ & Needs \\
\hline $\begin{array}{l}\text { Deflagration } \\
\text { outside hot } \\
\text { cell } \\
\text { - Release of } \\
\text { radioactive } \\
\text { materials and } \\
\text { chemicals }\end{array}$ & $\begin{array}{l}\text { Up to threshold } \\
\text { quantities of } \\
\text { Category } 2 \\
\text { inventory - } \\
\text { bounded by } \\
\text { plutonium. } \\
\text { Chemical inventory } \\
\text { maintained at } \\
\text { SIH levels - } 25 \% \\
\text { PSM thresholds } \\
\text { - bounded by } \\
\text { uranium } \\
\text { hexafluoride. }\end{array}$ & $\begin{array}{l}\text { Airborne release of } \\
\text { up to Category } 2 \\
\text { threshold } \\
\text { quantities of } \\
\text { radioactive } \\
\text { material to } \\
\text { atmosphere and } \\
\text { of } 25 \% \text { of PSM } \\
\text { (CFR 1998) } \\
\text { chemical } \\
\text { quantities to } \\
\text { atmosphere. }\end{array}$ & $\begin{array}{l}\text { 1. Electrical short. } \\
\text { 2. Electrical } \\
\text { switches or } \\
\text { controls spark. } \\
\text { 2a. Deflagration of } \\
\text { vapors from } \\
\text { flammable } \\
\text { materials. } \\
\text { 2b. Deflagration of } \\
\text { flammable gas, } \\
\text { e.g., tritium gas. } \\
\text { 3. Earthquake. } \\
\text { 3a. Deflagration of } \\
\text { vapors from } \\
\text { flammable } \\
\text { materials. } \\
\text { 3b. Deflagration of } \\
\text { natural gas. } \\
\text { 4. Aircraft crash } \\
\text { with fuel ignition. }\end{array}$ & $\begin{array}{l}\text { Spacious facilities }(1,2) \text {. } \\
\text { Electrical equipment } \\
\text { maintenance }(2) \text {. } \\
\text { Forklift training (2). } \\
\text { Pressurized gases in industrial } \\
\text { containers }(2 a, 2 b) \text {. } \\
\text { Flammable materials stored } \\
\text { appropriately }(2 a, 2 b) \text {. } \\
\text { Administrative controls on } \\
\text { flammable material inventory } \\
(2 a, 2 b) \text {. }\end{array}$ & $\begin{array}{l}\text { Fire protection response (all). } \\
\text { Emergency response training for } \\
\text { workers (all). } \\
\text { Controls on total inventory of } \\
\text { radioactive material (all). }\end{array}$ & $\begin{array}{l}\text { Forklift maintenance. } \\
\text { Electrical equipment } \\
\text { maintenance. } \\
\text { Administrative controls on } \\
\text { total inventory of } \\
\text { radioactive material. } \\
\text { Administrative controls on } \\
\text { flammable materials. } \\
\text { Emergency preparedness. } \\
\text { Forklift training. } \\
\text { OP on material storage, } \\
\text { surveillance for leaks. }\end{array}$ \\
\hline
\end{tabular}

tThis event is considered to be implausible on the basis of initial qualitative assessment and has been dropped from further consideration. It is not carried into the analysis in Appendix 3-B. 


\begin{tabular}{|c|c|c|c|c|c|c|}
\hline $\begin{array}{l}\text { Scenario } \\
\text { C1 }\end{array}$ & $\begin{array}{l}\text { Material at } \\
\text { Risk }\end{array}$ & Consequence & $\begin{array}{l}\text { Initiàting } \\
\text { Event }\end{array}$ & $\begin{array}{l}\text { Rrevention (Applicable } \\
\text { Initiating Event) }\end{array}$ & $\begin{array}{l}\text { Mitigation (Applicable } \\
\text { Initiating Event) }\end{array}$ & $\begin{array}{l}\text { Needs } \\
2\end{array}$ \\
\hline $\begin{array}{l}\text { Contamination } \\
\text { - Outside } \\
\text { hot cell }\end{array}$ & $\begin{array}{l}\text { Up to threshold } \\
\text { quantities of } \\
\text { Category } 2 \\
\text { inventory of } \\
\text { fission products. }\end{array}$ & $\begin{array}{l}\text { Contamination of } \\
\text { building interior } \\
\text { and local worker } \\
\text { exposure. }\end{array}$ & $\begin{array}{l}\text { 1. Forklift or crane } \\
\text { drops or spills } \\
\text { package. } \\
\text { 2. Package } \\
\text { surface } \\
\text { contaminated } \\
\text { (inadequate } \\
\text { surveillance). } \\
\text { 3. Fire protection } \\
\text { water } \\
\text { contaminates } \\
\text { building. } \\
\text { 4. Drum HEPA filter } \\
\text { improperly } \\
\text { secured. } \\
\text { 5. Package } \\
\text { dropped down } \\
\text { storage holes. } \\
\text { 6. Earthquake. } \\
\text { 7. Aircraft crash } \\
\text { with fuel ignition. }\end{array}$ & $\begin{array}{l}\text { Crane and hoist training (1). } \\
\text { Crane and hoist maintenance } \\
\text { (1). } \\
\text { Radiation surveillance (1-5). }\end{array}$ & $\begin{array}{l}\text { Emergency response training for } \\
\text { workers (all). } \\
\text { Radiation monitors detect } \\
\text { suspended particles }(1,2,4,5) \text {. } \\
\text { Fire protection chemicals fully } \\
\text { contained (3). }\end{array}$ & $\begin{array}{l}\text { Radiation monitors } \\
\text { maintained and calibrated. } \\
\text { Crane and hoist } \\
\text { maintenance. } \\
\text { OP including response to } \\
\text { contamination event. }\end{array}$ \\
\hline
\end{tabular}

\begin{tabular}{|c|c|c|c|c|c|c|}
\hline $\begin{array}{l}\text { Scenario } \\
\text { Cr1* }\end{array}$ & $\begin{array}{l}\text { Material at } \\
\text { Risk }\end{array}$ & Consequénce & $\begin{array}{l}\text { Initiating } \\
\text { Event }\end{array}$ & $\begin{array}{l}\text { Prevention (Applicable } \\
\text { Initiating Event) }\end{array}$ & $\begin{array}{l}\text { Mitigation (Applicable } \\
\text { Initiating Event) }\end{array}$ & Needs \\
\hline Crilicality & Not applicable. & $\begin{array}{l}\text { Worker exposure to } \\
\text { external radiation. }\end{array}$ & $\begin{array}{l}\text { 1. Violation of } \\
\text { administration } \\
\text { procedures. } \\
\text { 2. Flooding (natural } \\
\text { or fire protection } \\
\text { water). } \\
\text { 3. Inadequate } \\
\text { inventory control. }\end{array}$ & $\begin{array}{l}\text { Administrative controls on } \\
\text { configuration and inventory } \\
\text { (all). } \\
\text { Use of storage holes (all). } \\
\text { CSAs (all). } \\
\text { Process controls (all). } \\
\text { Work controls (all). } \\
\text { Drainage for fire protection } \\
\text { water (2). }\end{array}$ & $\begin{array}{l}\text { Shielded walls of the hol cell (all). } \\
\text { Criticality monitors as required by } \\
\text { the CSA (all). }\end{array}$ & $\begin{array}{l}\text { Administrative controls on } \\
\text { inventory of fissile material. } \\
\text { Monitoring of integrity of } \\
\text { shield. } \\
\text { Criticality monitors as } \\
\text { required by the CSA. } \\
\text { Criticality safety training for } \\
\text { workers. } \\
\text { CSAs. }\end{array}$ \\
\hline
\end{tabular}

*Criticality is addressed through SNL's Criticality Safety Program and will be described in Chapter 6 of the SAR. No further analysis is presented in Chapter 3. 


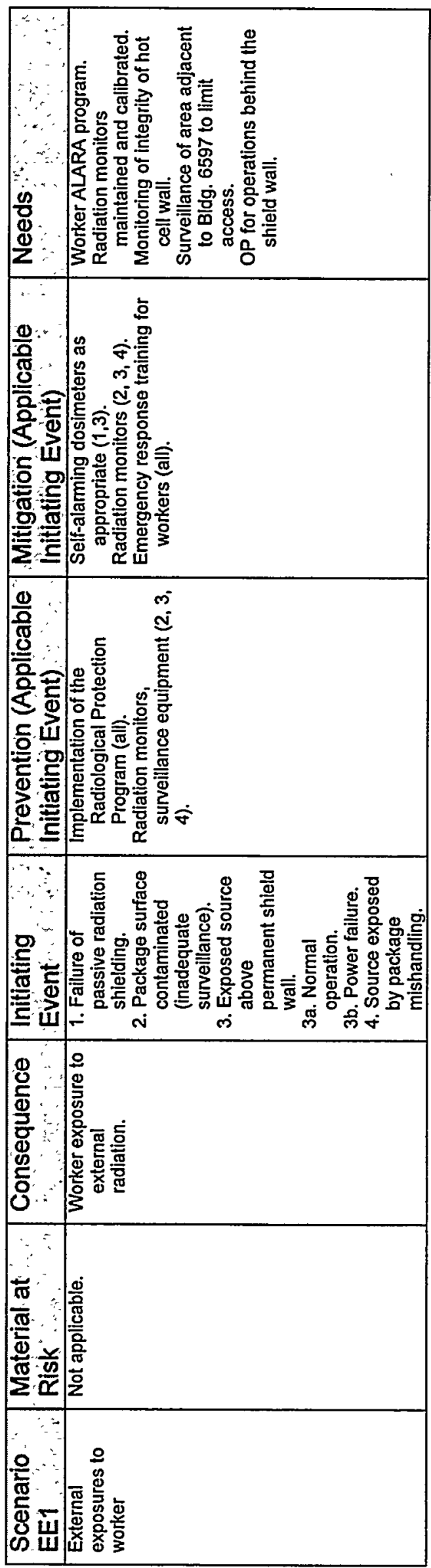

$\sum_{n}^{1}$ 


\section{APPENDIX 3-B \\ Probability TABLE for Hazard EVAluation}

The following tables present estimates of the annual frequency of occurrence of various accidents identified in the PHA (Appendix 3-A). No prevention or mitigation measures are considered. The frequency of operations is estimated based on processing of 70 packages per year, with an estimated process time of three days per package. Although the number of packages processed per year could vary somewhat, an order of magnitude increase would be necessary to affect the resulting risk values.

The probabilities of events in the accident scenarios were estimated in two ways:

- using the expert judgment of the analysts working on the AHCF project, or

- using the collective operating experience within the DOE complex. In the latter case, a specific reference is given in the last column.

In most cases, a series of independent events is required for an accident to occur. In some cases, a single initiating event can lead to an accident by several pathways. In this case, each event is presented as a subset of a common initiating event.

The estimated annual frequency of occurrence of a given accident is the product of the annual frequency of the operation in question and the independent probabilities of each of the contributing events. For example, in the first scenario, F1-Fire Inside Hot Cell, accident $1 \mathrm{a}$ is postulated to occur when flammable constituents of waste are ignited by sparking or arcing of switches associated with electronic equipment in the hot cell. The expected annual frequency of this accident is determined as described below:

- The annual frequency of processing wastes containing flammable materials is estimated at .1 (once every 10 years).

- The probability of release of these materials from the package is estimated at 01 .

- The estimated probability of sparking of electrical equipment or controls is .1 .

- The conditional probability of deflagration occurring, given that flammables are released and sparking, etc., occurs, is an estimated.1.

The estimated annual frequency of this event is therefore

.1 events/yr x .01 (release from package) $\times .1$ (sparking of electrical equipment or controls) $\mathrm{x} .1$ (ignition) $=1 \times 10^{-5}$ per year. 
F1 - Fire Inside Hot Cell with Release of Radioactive Materials and Chemicals

\begin{tabular}{|c|c|c|c|c|c|}
\hline Initiating Event & Assumptions & $\begin{array}{l}\text { Estlimated } \\
\text { Probabillty of } \\
\text { Occurrence } \\
\text { per Operation }\end{array}$ & $\begin{array}{l}\text { Estimated } \\
\text { Annual } \\
\text { Frequency } \\
\text { of Operation }\end{array}$ & $\begin{array}{l}\text { Aninual Frequency of } \\
\text { Scenario } \\
\text { (Contributing } \\
\text { Events } \\
\text { Calculation] }\end{array}$ & 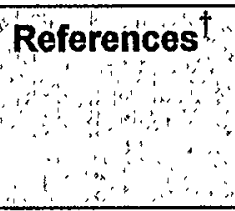 \\
\hline $\begin{array}{l}1 \text { Electrical switches or } \\
\text { controls spark. }\end{array}$ & $\begin{array}{l}\text { Off-normal event (extremely } \\
\text { conservative estimate based on } \\
\text { operating experience). }\end{array}$ & .1 & & & \\
\hline $\begin{array}{l}\text { 1a. Ignition of flammable } \\
\text { materiais, such as } \\
\text { solvents. }\end{array}$ & $\begin{array}{l}\text { Flammable materials are not a known } \\
\text { constituent of existing wastes beyond } \\
\text { trace amounts. Arbitrarily assumed to } \\
\text { occur in amounts to sustain ignition } \\
\text { (about } 3 \text { liters) once every } 700 \\
\text { packages of waste - encountered } \\
\text { once every ten years (.1). Probability } \\
\text { of release from package due to leak or } \\
\text { spill set at } .01 \text {. Ignition probability set } \\
\text { at } 1\end{array}$ & $\begin{array}{l}.01 \text { (release } \\
\text { from package) } \\
\text { and } \\
.1 \text { (ignition) }\end{array}$ & .1 & $\begin{array}{l}1 \times 10^{-5} \\
(1 \times 1 a) \\
{[.1 \times .01 \times .1 \times .1]}\end{array}$ & \\
\hline $\begin{array}{l}\text { 1b. Ignition of waste oil } \\
\text { or other } \\
\text { combustibles. }\end{array}$ & $\begin{array}{l}\text { Combustibles are not a known consti- } \\
\text { tuent of existing wastes beyond trace } \\
\text { amounts. Arbitrarily assumed to occur } \\
\text { in combustible amounts once every } 35 \\
\text { packages of waste - encountered } \\
\text { twice a year (2). Probability of release } \\
\text { from package due to leak or spill set at } \\
.01 \text {. Combustion probability set at } \\
1 \times 10^{-4} \text {. }\end{array}$ & $\begin{array}{l}.01 \text { (release } \\
\text { from package) } \\
\text { and } .0001\end{array}$ & 2 & $\begin{array}{l}2 \times 10^{-7} \\
(1 \times 1 \mathrm{~b}) \\
{[.1 \times .01 \times .0001 \times 2]}\end{array}$ & \\
\hline
\end{tabular}

* This column explains the values used in columns 3 and 4 .

** Numbers in parentheses refer back to the events in column 1.

${ }^{\dagger}$ Entries without references represent the engineering judgment of AHCF project participants. 
F1 - Fire Inside Hot Cell with Release of Radioactive Materials and Chemicals (continued)

\begin{tabular}{|c|c|c|c|c|c|}
\hline Initiating Event & Assumptions & $\begin{array}{l}\text { Estimated } \\
\text { Probability of } \\
\text { Occúrrence } \\
\text { peroperation }\end{array}$ & $\begin{array}{l}\text { Estimated } \\
\text { Annual } \\
\text { Frequency } \\
\text { of Operation }\end{array}$ & $\begin{array}{l}\text { Annual Frequency of } \\
\text { Scenario } \\
\text { (Contributing } \\
\text { Events") } \\
\text { [Calculation] }\end{array}$ & $\begin{array}{l}\text { References } \\
\because \vdots \\
\because \\
\because\end{array}$ \\
\hline $\begin{array}{l}\text { 1c. Ignition of window oil } \\
\text { - leak or puncture by } \\
\text { crane during loading. }\end{array}$ & $\begin{array}{l}\text { Puncture by crane or hoist assuming } \\
\text { typical visibility and no spotter }\left(3 \times 10^{-5}\right) \text {. } \\
\text { Probability given by DOE ( } 1996 a) \text { was } \\
\text { decreased by a factor of } 01 \text { because } \\
\text { the centralized positioning of this crane } \\
\text { decreases ability to shatter glass. } \\
\text { Ignition probability given release of } \\
\text { combustibles and generation of a } \\
\text { spark set at } 1 \times 10^{-4} \text {. }\end{array}$ & $\begin{array}{l}3 \times 10^{-5} \text { (cranel } \\
\text { hoist strikes } \\
\text { stationary } \\
\text { object); } .01 \\
\text { (crane strikes } \\
\text { stationary } \\
\text { object); and } \\
1 \times 10^{-4} \text { ignition }\end{array}$ & 70 & $\begin{array}{l}2 \times 10^{-10} \\
(1 \times 10) \\
{\left[.1 \times 3 \times 10^{-5} \times .01 \times\right.} \\
\left.1 \times 10^{-4} \times 70\right]\end{array}$ & $\begin{array}{l}\text { DOE } \\
(1996 a \hat{a} \\
\text { Table B.4) }\end{array}$ \\
\hline $\begin{array}{l}\text { 1d. Ignition of flammable } \\
\text { gas. }\end{array}$ & $\begin{array}{l}\text { Flammable gas is not a known or } \\
\text { expected constituent of existing wastes } \\
\text { beyond trace amounts. Arbitrarily } \\
\text { assumed to occur once every } 700 \\
\text { packages of waste - encountered } \\
\text { once every } 10 \text { years }(.1) \text {. Probability } \\
\text { of release from the container set at .1. } \\
\text { Ignition probability set at. } 1 .\end{array}$ & $\begin{array}{l}.1 \text { (release from } \\
\text { package) } \\
\text { and } \\
.1 \text { (ignition) }\end{array}$ & .1 & $\begin{array}{l}1 \times 10^{-4} \\
(1 \times 1 d) \\
{[.1 \times .1 \times .1 \times .1]}\end{array}$ & $\because$ \\
\hline $\begin{array}{l}\text { 2. Overheating of } \\
\text { exothermic chemical } \\
\text { reaction (e.g., acid- } \\
\text { base neutralization or } \\
\text { solidification). }\end{array}$ & $\begin{array}{l}\text { Procedure not currently required or } \\
\text { planned. Assumed to be utilized in } \\
\text { significant amounts once every } 700 \\
\text { packages of waste or once every ten } \\
\text { years }(1) \text {. Operator error assumed } \\
\left(1 \times 10^{-2}\right) \text {. }\end{array}$ & $\begin{array}{l}.01 \text { (operator } \\
\text { error) }\end{array}$ & $\begin{array}{l}.1 \text { (acid-base } \\
\text { neutraliza- } \\
\text { tion) }\end{array}$ & & $\begin{array}{l}\text { DOE } \\
\text { (1996a; } \\
\text { Table B-4). }\end{array}$ \\
\hline $\begin{array}{l}\text { 2a. Ignition of flammable } \\
\text { materials, such as } \\
\text { solvents. }\end{array}$ & See $1 \mathrm{a}$. & $\begin{array}{l}.01 \text { ( release } \\
\text { from package) } \\
\text { and } .1 \text { (ignition) }\end{array}$ & $\begin{array}{l}1 \text { (flammable } \\
\text { materials in } \\
\text { waste) }\end{array}$ & $\begin{array}{l}1 \times 10^{-7} \\
(2 \times 2 \mathrm{a}) \\
{[.01 \times .1 \times .01 \times .1 \times .1]}\end{array}$ & \\
\hline
\end{tabular}




\section{F1 - Fire Inside Hot Cell with Release of Radioactive Materials and Chemicals (continued)}

\begin{tabular}{|c|c|c|c|c|c|}
\hline Initiating Event & $\begin{array}{l}\text { Assumptions } \\
\text { Asumats }\end{array}$ & $\begin{array}{l}\text { Estimated } \\
\text { Probabillty of } \\
\text { Occuirrence } \\
\text { per Operation }\end{array}$ & $\begin{array}{l}\text { Estimated } \\
\text { Annual } \\
\text { Frequency } \\
\text { of Operation }\end{array}$ & $\begin{array}{l}\text { Annual Frequency of } \\
\text { Scenario } \\
\text { (Contributing } \\
\text { Event's) } \\
\text { [Calculatlon] }\end{array}$ & References \\
\hline $\begin{array}{l}2 \mathrm{~b} \text {. Ignition of waste oil } \\
\text { or other combustibles. }\end{array}$ & See $1 b$. & $\begin{array}{l}.01 \text { ( release } \\
\text { from package) } \\
\text { and.0001 } \\
\text { (combustion) }\end{array}$ & 2 & $\begin{array}{l}2 \times 10^{-9} \\
(2 \times 2 b) \\
{[.01 \times .1 \times .01 \times .0001} \\
\times 2] \\
\end{array}$ & \\
\hline $\begin{array}{l}\text { 2c. Ignition of flammable } \\
\text { gas. }\end{array}$ & See 1d. & $\begin{array}{l}.1 \text { (release from } \\
\text { package) and } \\
.1 \text { (ignition) }\end{array}$ & .1 & $\begin{array}{l}1 \times 10^{-6} \\
(2 \times 2 \mathrm{c}) \\
{[.01 \times .1 \times .1 \times .1 \times .1]} \\
\end{array}$ & \\
\hline $\begin{array}{l}\text { 3. Autoignition of } \\
\text { reactive metals. }\end{array}$ & $\begin{array}{l}\text { Sodium is a known component of a } \\
\text { small percentage of existing waste } \\
\text { packages; } 4 \text { packages per year are } \\
\text { assumed to be presented at the AHCF. } \\
\text { Operator error estimated as } .01 \text {. } \\
\text { lgnition during processing is consider- } \\
\text { ed an off-normal occurrence (probabili- } \\
\text { ty about .01); all Na-bearing packages } \\
\text { are conservatively assumed to require } \\
\text { processing. }\end{array}$ & $\begin{array}{l}.01 \text { (operator } \\
\text { error) and } .01 \\
\text { (ignition) }\end{array}$ & 4 & $\begin{array}{l}4 \times 10^{-4} \\
{[.01 \times .01 \times 4]}\end{array}$ & \\
\hline 4. Earthquake. & $\begin{array}{l}\text { Design basis earthquake }(0.22 \mathrm{~g}) \\
\text { collapse of crane or Building } 6597 \\
\text { structure destroys hot cell. }\end{array}$ & & $7 \times 10^{-4}$ & & DOE (1999) \\
\hline $\begin{array}{l}\text { 4a. Ignition of natural } \\
\text { gas. }\end{array}$ & $\begin{array}{l}\text { Building heated by boiler system. Gas } \\
\text { lines located behind a fire wall in the } \\
\text { Mid Bay. Probability of ignition .1. }\end{array}$ & $\begin{array}{l}1 \text { (collapse of } \\
\text { fire wall and } \\
\text { ignition of } \\
\text { natural gas) }\end{array}$ & & $\begin{array}{l}7 \times 10^{-5} \\
(4 \times 4 a) \\
{\left[.1 \times 7 \times 10^{-4}\right]}\end{array}$ & \\
\hline
\end{tabular}


F1 - Fire Inside Hot Cell with Release of Radioactive Materials and Chemicals (concluded)

\begin{tabular}{|c|c|c|c|c|c|}
\hline Initiating Event & Assumptions & $\begin{array}{l}\text { Estimated } \\
\text { Probability of } \\
\text { Occurrence } \\
\text { per Operation }\end{array}$ & $\begin{array}{l}\text { Estimated } \\
\text { Annual } \\
\text { Frequency } \\
\text { of Operation }\end{array}$ & $\begin{array}{l}\text { Annual Frequency of } \\
\text { Scenario } \\
\text { (Contributing } \\
\text { Events*) } \\
\text { [Calculatlon] }\end{array}$ & $\begin{array}{l}\text { References } \\
\ddots \\
\ddots \\
\ddots \\
\ddots\end{array}$ \\
\hline $\begin{array}{l}4 \mathrm{~b} . \text { Ignition of flammable } \\
\text { material. }\end{array}$ & $\begin{array}{l}\text { Flammable materials in these } \\
\text { quantities unknown in current waste. } \\
\text { Considered to occur once every } 10 \\
\text { years }(.1) \text {. }\end{array}$ & & $\begin{array}{l}.1 \text { times a } \\
\text { year waste } \\
\text { type }\end{array}$ & $\begin{array}{l}7 \times 10^{-5} \\
(4 \times 4 b) \\
{\left[7 \times 10^{-4} \times 1\right]}\end{array}$ & \\
\hline 5. Aircraft crash. & Fuel ignites. & & $5 \times 10^{-5}$ & $5 \times 10^{-5}$ & DOE (1999) \\
\hline
\end{tabular}


F2 - Fire Outside Hot Cell with Release of Radioactive Materials and Chemicals

\begin{tabular}{|c|c|c|c|c|c|}
\hline Initlating Event & Assumptions & $\begin{array}{l}\text { Estimated } \\
\text { Probability of } \\
\text { Occurrence } \\
\text { per Operation }\end{array}$ & $\begin{array}{l}\text { Estimated } \\
\text { Annual } \\
\text { Frequency } \\
\text { of Operation }\end{array}$ & $\begin{array}{l}\text { Aninual Frequency of } \\
\text { Scénario } \\
\text { (Contributling } \\
\text { Events') } \\
\text { (Calculatión }\end{array}$ & 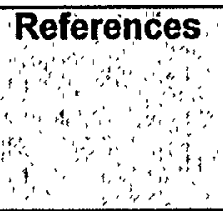 \\
\hline $\begin{array}{l}\text { 1. Electrical switches or } \\
\text { controls spark. }\end{array}$ & $\begin{array}{l}\text { Off-normal event (extremely } \\
\text { conservative estimate based on } \\
\text { operating experience). }\end{array}$ & .1 & & & \\
\hline $\begin{array}{l}\text { 1a. Ignition of a large } \\
\text { spill of flammable } \\
\text { materials, such as } \\
\text { solvents. }\end{array}$ & $\begin{array}{l}\text { Would require a spill of greater than } 10 \\
\text { gallons of volatile flammables. (Ignition } \\
\text { of vapor leaking from packages or of } \\
\text { flammable gas is considered incredible } \\
\text { because of the large amount required } \\
\text { to reach the lower flammability limit in } \\
\text { this space.) Probability of ignition set at } \\
1 \text {. }\end{array}$ & $\begin{array}{l}.1 \text { (probability } \\
\text { of ignition) }\end{array}$ & & & \\
\hline $\begin{array}{l}\text { 1a.1. Major package } \\
\text { mishandling. }\end{array}$ & $\begin{array}{l}\text { Flammables in these quantities } \\
\text { unknown in current waste. Considered } \\
\text { to occur once every } 700 \text { packages or } \\
\text { once every } 10 \text { years (.1). } 400 \text { package } \\
\text { movements per year assumed. }\end{array}$ & $\begin{array}{l}1 \times 10^{-5} \\
\text { (package } \\
\text { mishandling) }\end{array}$ & $\begin{array}{l}400 \text { move- } \\
\text { ments per } \\
\text { year, and } \\
\text { waste type } \\
\text { handled.1 } \\
\text { times per } \\
\text { year }\end{array}$ & $\begin{array}{l}4 \times 10^{-6} \\
(1 \times 1 \mathrm{a} \times 1 \mathrm{a} .1) \\
{\left[.1 \times .1 \times 1 \times 10^{-5} \times 400\right.} \\
\times .1]\end{array}$ & $\begin{array}{l}\text { EG\&G } \\
(1983)\end{array}$ \\
\hline
\end{tabular}


F2 - Fire Outside Hot Cell with Release of Radioactive Materials and Chemicals (continued)

\begin{tabular}{|c|c|c|c|c|c|}
\hline Initiating Event & Assumptions & $\begin{array}{l}\text { Estimated } \\
\text { Probability of } \\
\text { Occurrence } \\
\text { per Operation }\end{array}$ & $\begin{array}{l}\text { Estimated } \\
\text { Annual } \\
\text { Frequency } \\
\text { of Operation }\end{array}$ & $\begin{array}{l}\text { Annual Frequency of } \\
\text { Scenario } \\
\text { (Contributling } \\
\text { Events') } \\
\text { [Calcuilation] }\end{array}$ & $\begin{array}{l}\text { References } \\
\ddots\end{array}$ \\
\hline 1a.2. Package leak. & $\begin{array}{l}\text { Most packages (estimated } 99 \% \text { ) } \\
\text { double contained or Type A shipping; } \\
\text { considered not vulnerable to leak. } \\
\text { Single-containment vessels assumed } \\
\text { to occur once every } 10 \text { years. Proba- } \\
\text { bility of leakage of single containment } \\
\text { vessel estimated as } .01 \text {. Flammables } \\
\text { in these quantities unknown in current } \\
\text { waste. Assumed to occur once every } \\
700 \text { packages or once every } 10 \text { years } \\
\text { (.1). } 400 \text { package movements per year } \\
\text { assumed. }\end{array}$ & $\begin{array}{l}.01 \text { (Probability } \\
\text { of leakage of } \\
\text { single } \\
\text { containment } \\
\text { vessel) }\end{array}$ & $\begin{array}{l}.1 \text { times a } \\
\text { year waste } \\
\text { type, and } \\
\text { waste type } \\
\text { handled.1 } \\
\text { times per } \\
\text { year }\end{array}$ & $\begin{array}{l}1 \times 10^{-6} \\
(1 \times 1 \mathrm{a} \times 1 \mathrm{a} .2) \\
{[.1 \times .1 \times .01 \times .1 \times .1]}\end{array}$ & $*$ \\
\hline $\begin{array}{l}\text { 2. Forklift moves } \\
\text { package. }\end{array}$ & & & $\begin{array}{l}400 \\
\text { movements } \\
\text { per year }\end{array}$ & & \\
\hline $\begin{array}{l}\text { 2a. Ignition from } \\
\text { equipment malfunction, } \\
\text { such as catastrophic } \\
\text { battery failure or the } \\
\text { leaking of hydraulic/ } \\
\text { brake fluid onto hot } \\
\text { brake surfaces. }\end{array}$ & & $1 \times 10^{-5}$ & & $\begin{array}{l}4 \times 10^{-3} \\
(2 \times 2 a) \\
{\left[400 \times 1 \times 10^{-5}\right]}\end{array}$ & $\begin{array}{l}\text { DOE } \\
\text { (1996a, } \\
\text { Table 2.6) }\end{array}$ \\
\hline 3. Earthquake. & Design basis earthquake. & & $7 \times 10^{-4}$ & & DOE (1999) \\
\hline $\begin{array}{l}\text { 3a. Ignition of natural } \\
\text { gas. }\end{array}$ & $\begin{array}{l}\text { Building heated by boiler system. Gas } \\
\text { lines located behind a fire wall in the } \\
\text { Mid Bay. Probability of ignition .1. }\end{array}$ & $\begin{array}{l}1 \text { (collapse of } \\
\text { fire wall and } \\
\text { ignition of } \\
\text { natural gas) }\end{array}$ & & $\begin{array}{l}7 \times 10^{-5} \\
(3 \times 3 a) \\
{\left[.1 \times 7 \times 10^{-4}\right]}\end{array}$ & 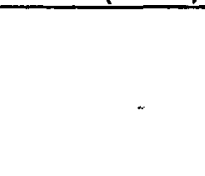 \\
\hline
\end{tabular}


F2 - Fire Outside Hot Cell with Release of Radioactive Materials and Chemicals (concluded)

\begin{tabular}{|c|c|c|c|c|c|}
\hline Initlating Event & $\begin{array}{l}\text { Assumptions } \\
\text { As }\end{array}$ & $\begin{array}{l}\text { Estlmated } \\
\text { Probability of } \\
\text { Occurrence } \\
\text { per operation }\end{array}$ & $\begin{array}{l}\text { Estinated } \\
\text { Anniual } \\
\text { Frequency } \\
\text { of Operation }\end{array}$ & $\begin{array}{l}\text { Annial Frequency of } \\
\text { Scenario } \\
\text { (Contributing } \\
\text { Events } \\
\text { [Calculation] }\end{array}$ & References \\
\hline $\begin{array}{l}\text { 3b. Ignition of flammable } \\
\text { material. }\end{array}$ & $\begin{array}{l}\text { Flammables in these quantities } \\
\text { unknown in current waste. Considered } \\
\text { to be stored in the High Bay for three } \\
\text { days once every } 10 \text { years }\left(8 \times 10^{-4}\right) \text {. } \\
\text { (Note that this event does not depend } \\
\text { on the number of operations per year, } \\
\text { but rather on the time the waste is in } \\
\text { storage.) }\end{array}$ & & $8 \times 10^{-4}$ & $\begin{array}{l}5.6 \times 10^{-7} \\
(3 \times 3 b) \\
{\left[7 \times 10^{-4} \times 8 \times 10^{-4}\right]}\end{array}$ & \\
\hline 4. Aircraft crash. & Fuel ignites. & & $5 \times 10^{-5}$ & $5 \times 10^{-5}$ & DOE (1999) \\
\hline
\end{tabular}


De1 - Deflagration Inside Hot Cell with Release of Radioactive Materials and Chemicals

\begin{tabular}{|c|c|c|c|c|c|}
\hline Initiating Event & Assumptions & $\begin{array}{l}\text { Estimated } \\
\text { Probability of } \\
\text { Occurrence } \\
\text { per Operation }\end{array}$ & $\begin{array}{l}\text { Estimated } \\
\text { Annual } \\
\text { Frequency } \\
\text { of Operation }\end{array}$ & $\begin{array}{l}\text { Annual Frequency of } \\
\text { Scenario } \\
\text { (Contributing } \\
\text { Events') } \\
\text { [Calculation] }\end{array}$ & $\begin{array}{l}\text { References } \\
\cdots \\
0\end{array}$ \\
\hline $\begin{array}{l}\text { 1. Electrical switches or } \\
\text { controls spark. }\end{array}$ & $\begin{array}{l}\text { Off-normal event (extremely } \\
\text { conservative estimate). }\end{array}$ & 1 & & & \\
\hline $\begin{array}{l}\text { 1a. Deflagration of } \\
\text { vapors from flammable } \\
\text { materials. }\end{array}$ & $\begin{array}{l}\text { Flammable materials are not a known } \\
\text { constituent of existing wastes beyond } \\
\text { trace amounts. Arbitrarily assumed to } \\
\text { occur in LEL amounts, or estimated } 3 \\
\text { liters - once every ten years (.1). } \\
\text { Probability of release from container } \\
\text { due to spill or leak set at .01. } \\
\text { Probability of deflagration given vapor } \\
\text { release and spark set at } 1.0 \text {. }\end{array}$ & $\begin{array}{l}.01 \text { (release } \\
\text { from container) }\end{array}$ & .1 & $\begin{array}{l}1 \times 10^{-4} \\
(1 \times 1 a) \\
{[.1 \times .01 \times .1]}\end{array}$ & \\
\hline $\begin{array}{l}\text { 1b. Deflagration of } \\
\text { flammable gas. }\end{array}$ & $\begin{array}{l}\text { Flammable gas is not a known or } \\
\text { expected constituent of existing wastes } \\
\text { beyond trace amounts. Arbitrarily } \\
\text { assumed to occur in deflagration } \\
\text { amounts once every } 700 \text { packages of } \\
\text { waste - encountered once every } 10 \\
\text { years (.1). Probability of release from } \\
\text { container due to spill or leak set at. } 1 \text {. } \\
\text { Probability of deflagration given } \\
\text { flammable gas release and spark set } \\
\text { at } 1.0 \text {. }\end{array}$ & $\begin{array}{l}.1 \text { (release from } \\
\text { container) }\end{array}$ & .1 & $\begin{array}{l}1 \times 10^{-3} \\
(1 \times 1 b) \\
{[.1 \times .1 \times .1]}\end{array}$ & . \\
\hline $\begin{array}{l}\text { 2. Deflagration of } \\
\text { hydrogen generated by } \\
\text { acid-base neutralization. }\end{array}$ & $\begin{array}{l}\text { Procedure not currently required or } \\
\text { planned. Process volumes sufficient to } \\
\text { release } 8 \mathrm{~g} \text { of hydrogen assumed to be } \\
\text { present once every } 10 \text { years }(.1) \text {. } \\
\text { Assumes major error in simple } \\
\text { chemical process }\left(5 \times 10^{-4}\right) \text {. }\end{array}$ & $5 \times 10^{-4}$ & .1 & $\begin{array}{l}5 \times 10^{-5} \\
{\left[5 \times 10^{-4} \times .1\right]}\end{array}$ & $\begin{array}{l}\text { DOE } \\
\text { (1996a, } \\
\text { Table B-4) }\end{array}$ \\
\hline
\end{tabular}


De1 - Deflagration Inside Hot Cell with Release of Radioactive Materials and Chemicals (concluded)

\begin{tabular}{|c|c|c|c|c|c|}
\hline Initiating Event & Assumptions & $\begin{array}{l}\text { Estlimated } \\
\text { Probability of } \\
\text { Occurrence } \\
\text { per Operation }\end{array}$ & $\begin{array}{l}\text { Estlmated } \\
\text { Annual } \\
\text { Frequéncy } \\
\text { of Operation }\end{array}$ & $\begin{array}{l}\text { Annual Frequency of } \\
\text { Scenario } \\
\text { (Contrlbutting } \\
\text { Events } \\
\text { [Calculation] }\end{array}$ & $\begin{array}{r}\text { References } \\
1 \\
4 \\
y\end{array}$ \\
\hline 3. Earthquake. & Design basis earthquake $(0.22 \mathrm{~g})$ & & $7 \times 10^{-4}$ & & \\
\hline 3a. Crane collapses cell. & $\begin{array}{l}\text { Loading assumed to take } 5 \text { minutes; } \\
\text { event occurs } 1000 \text { times per year. } \\
\text { Total fraction of time crane over hot } \\
\text { cell is } .01 \text {. }\end{array}$ & & .01 & $\begin{array}{l}7 \times 10^{-6} \\
(3 \times 3 a) \\
{\left[7 \times 10^{-4} \times .01\right]}\end{array}$ & $\begin{array}{l}\text { DOE } \\
\text { (1996b) }\end{array}$ \\
\hline 4. Aircraft crash. & Fuel ignites. & & $5 \times 10^{-5}$ & $5 \times 10^{-5}$ & DOE (1999) \\
\hline
\end{tabular}


De2 - Deflagration Outside Hot Cell with Release of Radioactive Materials and Chemicals

\begin{tabular}{|c|c|c|c|c|c|}
\hline Initiating Event & Assumptions & $\begin{array}{l}\text { Estimated } \\
\text { Probability of } \\
\text { Occurrence } \\
\text { per Operation }\end{array}$ & $\begin{array}{l}\text { Estimated } \\
\text { Annual } \\
\text { Frequency } \\
\text { of Operation }\end{array}$ & $\begin{array}{l}\text { Annual Frequency of } \\
\text { Scenario } \\
\text { (Contributing } \\
\text { Events*) } \\
\text { [Calculation] }\end{array}$ & $\begin{array}{c}\text { References } \\
\cdots \\
0\end{array}$ \\
\hline $\begin{array}{l}\text { 1. Electrical switches or } \\
\text { controls spark. }\end{array}$ & Off-normal event. & .1 & & & \\
\hline $\begin{array}{l}\text { 1a. Deflagration of } \\
\text { vapors from flammable } \\
\text { materials. }\end{array}$ & $\begin{array}{l}\text { Flammable materials are not a known } \\
\text { constituent of existing wastes beyond } \\
\text { trace amounts. Arbitrarily assumed to } \\
\text { occur in amounts sufficient to reach } \\
\text { LEL in the Building } 6597 \text { High Bay } \\
\text { once every } 100 \text { years (.01). Probability } \\
\text { of release of liquid from package due } \\
\text { to spill or leak set at .01. }\end{array}$ & .01 & .01 & $\begin{array}{l}1 \times 10^{-5} \\
(1 \times 1 \mathrm{a}) \\
{[.1 \times .01 \times .01]}\end{array}$ & \\
\hline $\begin{array}{l}\text { 1b. Deflagration of } \\
\text { flammable gas, such as } \\
\text { tritium gas. }\end{array}$ & $\begin{array}{l}\text { Flammable gases are not a known } \\
\text { constituent of existing wastes beyond } \\
\text { trace amounts. Arbitrarily assumed to } \\
\text { occur in amounts sufficient to reach } \\
\text { LEL in the Building } 6597 \text { High Bay } \\
\text { once every } 1000 \text { years. Probability of } \\
\text { package leak of gas set at. } 1 \text {. }\end{array}$ & .1 & .001 & $\begin{array}{l}1 \times 10^{-5} \\
(1 \times 1 \mathrm{~b}) \\
{[.1 \times .1 \times .001]}\end{array}$ & \\
\hline 2. Earthquake. & Design basis earthquake $(0.22 \mathrm{~g})$ & & $7 \times 10^{-4}$ & & DOE (1999) \\
\hline $\begin{array}{l}\text { 2a. Deflagration of } \\
\text { flarnmable vapors. }\end{array}$ & $\begin{array}{l}\text { Flammable materials are not a known } \\
\text { constituent of existing wastes beyond } \\
\text { trace amounts. Arbitrarily assumed to } \\
\text { occur in amounts sufficient to reach } \\
\text { LEL in the Building } 6597 \text { High Bay } \\
\text { once every } 100 \text { years. }\end{array}$ & & .01 & $\begin{array}{l}7 \times 10^{-6} \\
(2 \times 2 a) \\
{\left[7 \times 10^{-4} \times .01\right]}\end{array}$ & $-1,-1,0$ \\
\hline
\end{tabular}


De2 - Deflagration Outside Hot Cell with Release of Radioactive Materials and Chemicals (concluded)

\begin{tabular}{|c|c|c|c|c|c|}
\hline Initlating Event & Assumptions & $\begin{array}{l}\text { Estimated } \\
\text { Probability of } \\
\text { Occurrence } \\
\text { per Operation }\end{array}$ & $\begin{array}{l}\text { Estimated } \\
\text { Annual } \\
\text { Frequency } \\
\text { of Operation }\end{array}$ & $\begin{array}{l}\text { Annual Frequency of } \\
\text { Scenario } \\
\text { (Contributing } \\
\text { Events } \\
\text { [Calculation] }\end{array}$ & $\begin{array}{r}\text { References } \\
4 \\
4\end{array}$ \\
\hline $\begin{array}{l}2 b . \text { Deflagration of } \\
\text { natural gas. }\end{array}$ & $\begin{array}{l}\text { Building heated by boiler system. Gas } \\
\text { lines located behind a fire wall in the } \\
\text { Mid Bay. Probability of deflagration } \\
.01 \text {. }\end{array}$ & $\begin{array}{l}.01 \text { (collapse of } \\
\text { fire wall and } \\
\text { deflagration of } \\
\text { natural gas) }\end{array}$ & & $\begin{array}{l}7 \times 10^{-6} \\
(2 \times 2 b) \\
{\left[7 \times 10^{-4} \times .01\right]}\end{array}$ & \\
\hline 3. Aircraft crash. & Fuel ignites. & & $5 \times 10^{-5}$ & $\begin{array}{l}5 \times 10^{-5} \\
{\left[5 \times 10^{-5}\right]}\end{array}$ & DOE (1999) \\
\hline
\end{tabular}




\section{C1 - Radioactive Contamination Outside Hot Cell**}

\begin{tabular}{|c|c|c|c|c|c|}
\hline Initiating Event & $\begin{array}{c}\text { Assumptions } \\
\text { As }\end{array}$ & $\begin{array}{l}\text { Estimated } \\
\text { Probability of } \\
\text { Occurrence } \\
\text { per Operation }\end{array}$ & $\begin{array}{l}\text { Estimated } \\
\text { Annual } \\
\text { Frequency } \\
\text { of Operation }\end{array}$ & $\begin{array}{l}\text { Annual Frequency of } \\
\text { Scenario } \\
\text { (Contributing } \\
\text { Events } \\
\text { [Calculation] }\end{array}$ & \begin{tabular}{c} 
References \\
\hdashline \\
\hdashline
\end{tabular} \\
\hline $\begin{array}{l}\text { 1. Forklift or crane drops } \\
\text { or spills package. }\end{array}$ & $\begin{array}{l}\text { Package mishandling severe enough } \\
\text { to compromise containment. }\end{array}$ & $1 \times 10^{-5}$ & 400 & $\begin{array}{l}4 \times 10^{-3} \\
{\left[1 \times 10^{-5} \times 400\right]}\end{array}$ & $\begin{array}{l}\text { EG\&G } \\
(1983)\end{array}$ \\
\hline $\begin{array}{l}\text { 2. Package surface } \\
\text { contaminated } \\
\text { (inadequate } \\
\text { surveillance). }\end{array}$ & $\begin{array}{l}\text { Probability of contamination on surface } \\
\text { set at } .01 \text { because waste transported } \\
\text { from other facilities where surveillance } \\
\text { is done. Probability that contamination } \\
\text { significant set at .1. }\end{array}$ & $\begin{array}{l}.01 \text { (surface } \\
\text { contaminated) } \\
\text { and } 1 \\
\text { (probability that } \\
\text { contamination } \\
\text { significant) }\end{array}$ & 70 & .07 & \\
\hline $\begin{array}{l}\text { 3. Fire protection water } \\
\text { contaminates building. }\end{array}$ & Identical to probability of fire. & & & $4 \times 10^{-3}$ & $\begin{array}{l}\text { Scenario } \\
\text { F-2 }\end{array}$ \\
\hline $\begin{array}{l}\text { 4. Drum HEPA filter } \\
\text { improperly secured. }\end{array}$ & $\begin{array}{l}\text { Improper installation; insertion of } \\
\text { HEPA filter required on less than } 10 \% \\
\text { of waste (i.e., } 7 \text { packages per year). }\end{array}$ & .01 & 7 & $\begin{array}{l}7 \times 10^{-2} \\
{[.01 \times 7]}\end{array}$ & $\begin{array}{l}\text { DOE } \\
\left(1996 a_{1}\right. \\
\text { Table B-3) }\end{array}$ \\
\hline $\begin{array}{l}\text { 5. Package dropped } \\
\text { down storage holes. }\end{array}$ & $\begin{array}{l}\text { Package mishandling. Storage } \\
\text { movements } 50 \text { times per year. }\end{array}$ & $1 \times 10^{-5}$ & 50 & $\begin{array}{l}5 \times 10^{-4} \\
{\left[1 \times 10^{-5} \times 50\right]}\end{array}$ & $\begin{array}{l}\text { EG\&G } \\
(1983)\end{array}$ \\
\hline 6. Earthquake. & $\begin{array}{l}\text { Design basis earthquake }(0.22 \mathrm{~g}) \\
\text { ruptures containers. Administrative } \\
\text { controls will prevent the crane from } \\
\text { being parked over the hot cell when } \\
\text { not in use. }\end{array}$ & & $7 \times 10^{-4}$ & $7 \times 10^{-4}$ & DOE (1999) \\
\hline 7. Aircraft crash. & Containers ruptured. & & $5 \times 10^{-5}$ & $5 \times 10^{-5}$ & DOE (1999) \\
\hline
\end{tabular}

${ }^{* *}$ Contamination assumed to be less than $100 x$ the values in Appendix D to 10CFR835. 


\section{EE1 - External Exposures to Worker}

\begin{tabular}{|c|c|c|c|c|c|}
\hline initiating Event & Assumptions & $\begin{array}{l}\text { Estimated } \\
\text { Probability of } \\
\text { Occurrence } \\
\text { per.Operation }\end{array}$ & $\begin{array}{l}\text { Estimated } \\
\text { Aninual } \\
\text { Frequency } \\
\text { of Operation }\end{array}$ & $\begin{array}{l}\text { Annual Frequency of } \\
\text { Scenaario } \\
\text { (Contributing } \\
\text { Events } \\
\text { [Calculation] }\end{array}$ & $\begin{array}{l}\text { References } \\
1 \\
1\end{array}$ \\
\hline $\begin{array}{l}\text { 1. Failure of passive } \\
\text { radiation shielding. }\end{array}$ & $\begin{array}{l}\text { Breaches in glove boxes estimated by } \\
\text { (DOE 1996a) every .05 glove-box- } \\
\text { years, decreased by a factor of } .01 \\
\text { because of the tight construction of the } \\
\text { hot cell. }\end{array}$ & $5 \times 10^{-4}$ & $\begin{array}{l}\text { Not } \\
\text { applicable }\end{array}$ & $5 \times 10^{-4}$ & $\begin{array}{l}\text { DOE } \\
\text { (1996a, } \\
\text { Table A.6) }\end{array}$ \\
\hline $\begin{array}{l}\text { 2. Package surface } \\
\text { contaminated } \\
\text { (inadequate } \\
\text { surveillance). }\end{array}$ & $\begin{array}{l}\text { Probability of contamination on surface } \\
\text { set at } .01 \text { because waste transported } \\
\text { from other facilities. Probability that } \\
\text { contamination significant set at } 1 .\end{array}$ & $\begin{array}{l}.01 \\
\text { (contaminated) } \\
.1 \text { (significant) }\end{array}$ & 70 & $\begin{array}{l}7 \times 10^{-2} \\
{[.01 \times .1 \times 70]}\end{array}$ & $\begin{array}{l}\text { DOE } \\
\text { (1996a, } \\
\text { Table 2.6) }\end{array}$ \\
\hline $\begin{array}{l}\text { 3. Exposed source } \\
\text { above permanent shield } \\
\text { wall. }\end{array}$ & $\begin{array}{l}\text { Frequency of moving high-dose-rate } \\
\text { wastes into the hot cell assumed to } \\
\text { take } 5 \text { minutes; loading occurs } 20 \\
\text { times per year. }\end{array}$ & & 20 & & $\begin{array}{l}\text { DOE } \\
\text { (1996a, } \\
\text { Table 2.6) }\end{array}$ \\
\hline 3a. Normal operation. & $\begin{array}{l}\text { Worker approaching within } 50 \text { feet of } \\
\text { building during a given } 5 \text {-minute } \\
\text { interval set at } 01 \text {. }\end{array}$ & .01 & & $\begin{array}{l}.2 \\
(3 \times 3 a) \\
{[.01 \times 20]} \\
\end{array}$ & \\
\hline 3b. Power failure. & $\begin{array}{l}\text { Frequency of power outage three } \\
\text { times per year. Probability of power } \\
\text { outage during } 5 \text {-minute loading is } \\
1 \times 10^{-5} \text { (.08 hr/ } 8760 \mathrm{hr} \text { per year). } \\
\text { Worker approaching within } 80 \text { feet of } \\
\text { building during a given } 5 \text {-minute } \\
\text { interval set at } .01\end{array}$ & $\begin{array}{l}3 \times 10^{-5} \text { (power } \\
\text { outage) and } .01 \\
\text { (worker } \\
\text { approaches) }\end{array}$ & & $\begin{array}{l}6 \times 10^{-6} \\
(3 \times 3 b) \\
{\left[20 \times 3 \times 10^{-5} \times .01\right]}\end{array}$ & \\
\hline $\begin{array}{l}\text { 4. Source exposed by } \\
\text { package mishandling. }\end{array}$ & $\begin{array}{l}\text { Probability of package mishandling } \\
1 \times 10^{-5} \text { and } 400 \text { movements per year. } \\
\text { Probability of dropping package } \\
\text { exposing source, such as by popping } \\
\text { off the lid, set at } .01 \text {. }\end{array}$ & $\begin{array}{l}1 \times 10^{-5} \text { (drum } \\
\text { mishandling) } \\
\text { and } .01 \\
\text { (exposing } \\
\text { source) }\end{array}$ & 400 & $\begin{array}{l}4 \times 10^{-5} \\
{\left[1 \times 10^{-5} \times .01 \times 400\right]}\end{array}$ & $\begin{array}{l}\text { EG\&G } \\
(1983)\end{array}$ \\
\hline
\end{tabular}




\section{References}

(DOE 1999)

- U.S. Department of Energy, Draft Site-Wide Environmental Impact Statement for Sandia National Laboratories/New Mexico, DOE/EIS-0281, U.S. Department of Energy, Albuquerque, NM, April 1999.

(DOE 1996a)

(DOE 1996b)

U.S. Department of Energy, "Hazard and Barrier Analysis Guidance Document," U.S. Department of Energy, Washington, DC, 1996.

U.S. Department of Energy, DOE STD-1021-93, Chg. 1, "Natural Phenomena Hazards Performance Categorization Guidelines for Structures, Systems, and Components," U.S. Department of Energy, Washington, DC, January 1996.

(EG\&G 1983)

EG\&G Idaho, "Safety Analysis Report for the Radioactive Waste Management Complex at the Idaho National Engineering Laboratory," EG\&G Idaho, Idaho Falls, ID, 1983. 


\section{APPENDIX 3-C \\ DBA EVENT TREE ANALYSES}

Event tree (ET) analysis has been used to analyze the accident sequence and to evaluate the accident frequency as suggested by DOE (1996) and Mahn et al. (1995). ET analysis is a simple approach to delineating sequences of events that could lead to an undesired event. In the ET analysis, various systems or barriers are identified for each initiating event. These systems or barriers are designed to prevent the occurrence of the undesired event or to mitigate the progress of the accident. At each node, the success or failure of these systems or barriers, known as event tree headings, is shown graphically. The result is a pictorial representation of various combinations of systems or barriers that succeed or fail in preventing the occurrence of the undesired event. Accident frequency is analyzed by assigning a frequency to each success or failure for the specific accident sequence leading to the undesired event. Unless a specific reference is given in the event lists that follow below, frequencies or probabilities represent the judgment of the AHCF analysis team.

\section{3-C.1 Fire Inside Hot Cell-Ignition Of Flammable MATERIALS}

\section{3-C.1.1 Accident Sequence Development}

This DBA is defined as a fire inside the hot cell, fueled by flammable components of the material or waste until the self-sustaining temperature for $\mathrm{Pu}$ combustion is reached, resulting in release of radioactive material or waste components. This is Scenario F1, Event 1A, in Appendix 3-B.

Initiating Event:

Ignition of flammable material in the hot cell.

Preventive Controls:

1. Regular maintenance on electrical equipment.

2. Administrative controls on the waste types allowed in the hot cell, limiting flammable materials to levels recommended by UBC Table 3-D (ICBO 1997) for unsprinkled areas.

3. Procedures providing that no flammable materials will be left unattended in open containers.

4. Procedures for package inspection and spill response. 


\section{Mitigative Controls:}

1. Manual system for fire suppression.

2. Fire detection with alarms in ventilation ducts.

3. Emergency response training for workers.

No credit is taken for retention of particulates by the HEPA filters.

The DBA accident progression is defined as follows:

1. Waste or materials containing flammable components arrive.

2. Flammable materials are allowed in the hot cell in excess of administrative control limits.

3. The flammable component is released from the package by a spill or leak.

4. Spark from electrical equipment ignites the material.

\section{3-C.1.2 Accident Sequence and Frequency Analysis}

For this DBA, the undesired event is release of radioactive component of materials or wastes. Failure frequencies for the various nodes were developed from Mahn et al. (1995) and DOE (1996) or by expert judgment of the analysts. The ET analysis diagram is shown in Figure 3-C-1. The outcomes of the ET analysis in Figure 3-C-1 are shown as eleven branches. The outcomes represent the following detailed accident occurrence scenarios.

- Branch A: Flammable materials are a known constituent of the wastes; however, administrative controls fail to limit the volume of material entering the hot cell. The flammable materials become available to an ignition source due to spills, leaks, or normal processing. Ignition occurs, manual fire suppression fails, and the radioactive component of the waste is released.

- Branch B: Flammable materials are a known constituent of the wastes; however, administrative controls fail to limit the volume of material entering the hot cell. The flammable materials become available to an ignition source due to spills, leaks, or normal processing. Ignition occurs, but manual fire suppression is successful. No release occurs.

- Branch C: Flammable materials are a known constituent of the wastes; however, administrative controls fail to limit the volume of material entering the hot cell. The flammable materials become available to an ignition source due to spills, leaks, or normal processing. However, the material fails to ignite. No release occurs.

- Branch D: Flammable materials are a known constituent of the wastes; however, administrative controls fail to limit the volume of material entering the hot cell. The flammable materials become available to an ignition source due to spills, 
leaks, or normal processing. However, none of the electrical components spark, and there is no ignition source. No release occurs.

- Branch E: Flammable materials are a known constituent of the wastes; however, - administrative controls fail to limit the volume of material entering the hot cell. The flammable material remains containerized and unavailable to ignition sources. No release occurs.

- Branch F: Flammable materials are a known constituent of the wastes. However, administrative controls prevent the material from entering the hot cell. No release occurs.

- Branch G: Flammable materials are an unknown constituent of the wastes. The flammable materials become available to an ignition source due to spills, leaks, or normal processing. Ignition occurs, manual fire suppression fails, and the radioactive component of the waste is released.

- Branch H: Flammable materials are an unknown constituent of the wastes. The flammable materials become available to an ignition source due to spills, leaks, or normal processing. Ignition occurs. However, manual fire suppression is successful and no release occurs.

- Branch I: Flammable materials are an unknown constituent of the wastes. The flammable materials become available to an ignition source due to spills, leaks, or normal processing. An ignition source is available to ignite the waste, but flammable materials fail to ignite. No release occurs.

- Branch J: Flammable materials are an unknown constituent of the wastes. The flammable materials become available to an ignition source due to spills, leaks, or normal processing. No ignition source is available to ignite the waste. No release occurs.

- Branch K: Flammable materials are an unknown constituent of the waste. The flammable materials remain containerized and are unavailable to an ignition source. No release occurs.

- Failure probabilities for the various initiating events in the ET analysis are as follows:

- Event 1: Waste contains flammable materials. Flammable materials are not a constituent of existing SNL waste, but it is possible that flammable materials will be received in the future at the AHCF as either known or unknown constituents. This event is conservatively assumed to occur once every 700 packages or every 10 years ( 0.1 times a year). 


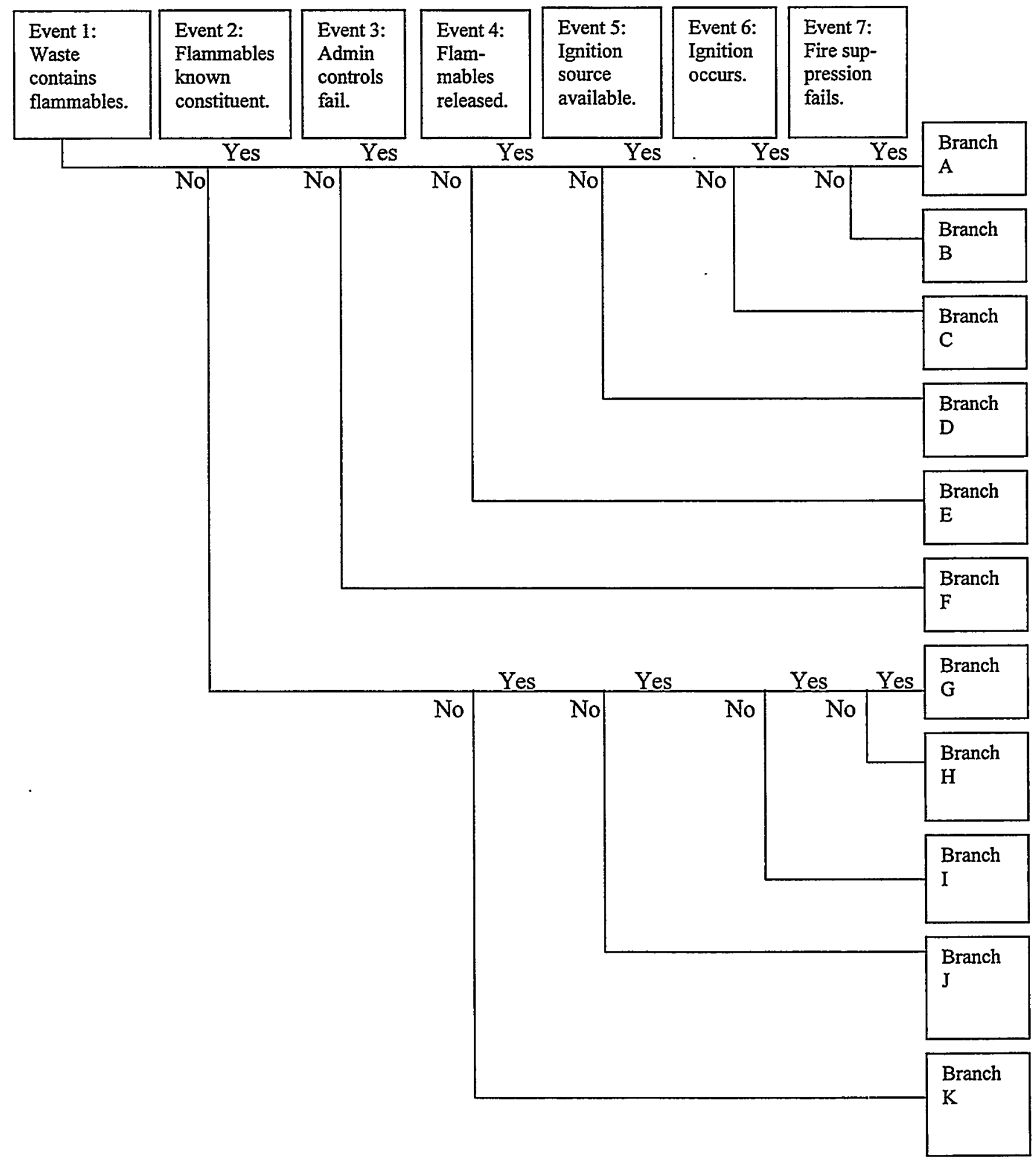

Figure 3-C-1. ET Analysis Diagram - DBA for Fire Inside Hot Cell-lgnition of Flammable Materials. 
- Event 2: Flammable materials are identified as a constituent of waste. Process knowledge on $95 \%$ of the packages allows identification of waste constituents. The probability of knowing the waste contents is estimated to be 0.95 .

- Event 3: Administrative controls prevent admission of excessive amounts of flammables into the hot cell. DOE (1996) estimated the failure rate of administrative controls to be $5 \times 10^{-3}$.

- Event 4: Material is released from the package due to spills, leaks, or a part of normal processing. This probability was estimated as 0.01 . The remote handling makes handling accidents more probable. Also, occasional processes may require unpackaging of liquid waste.

- Event 5: Ignition source is available. The most likely source would be sparks from electrical equipment. This is considered an off-normal event and conservatively set at 0.1 (DOE 1996).

- Event 6: Ignition occurs. If ignition source is weak or intermittent, the material may not ignite. Ignition probability is set at 0.1 .

- Event 7: Manual fire suppression is unsuccessful. DOE (1996) estimated the probability of failure of manual fire suppression as $10^{-2}$. However, the estimated process time for a package is three days and material will be left unattended overnight. Requirements to containerize unattended waste will reduce probability of ignition. This analysis takes no credit for fire suppression during the time the waste is unattended. Success rate for fire suppression is set at 0.3 .

The frequency of each operational outcome or branch for the event tree of Figure 3-C-1 is shown in Table 3-C-1. The probabilities in Table 3-C-1 must be interpreted in conjunction with the yes/no branches in Figure 3-C-1.

\section{3-C.1.3 Comparison of Accident Frequency from ET Analysis for Fire to the Hazard Evaluation Results}

The accident analysis shows that the expected accident probability (Table 3-C-1) is much less than the hazard evaluation (Tables 3-5 and 3-6) originally suggested. The accident is determined to be incredible, primarily because of the relatively rare occurrence of flammable material in the waste stream and because of administrative controls limiting quantities admitted into the hot cell. 
Table 3-C-1. Frequency of Occurrence Outcomes for Each Branch of the ET Analysis Diagram - DBA for Fire Inside Hot Cell-Ignition of Flammable Materials*

\begin{tabular}{|c|c|c|c|c|c|c|c|c|c|}
\hline$\frac{=}{\mathbf{g}}$ & 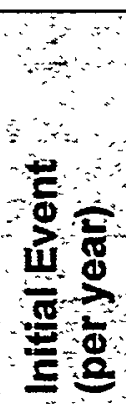 & 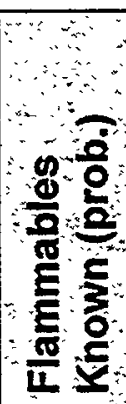 & 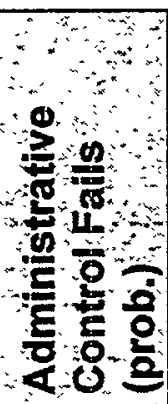 & 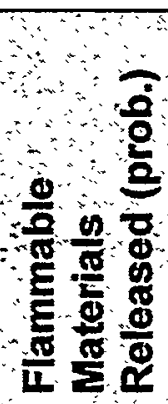 & 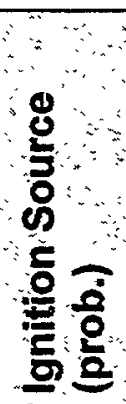 & $\frac{2}{0}$ & 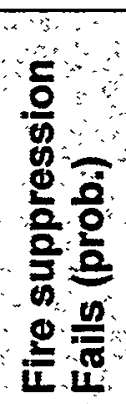 & 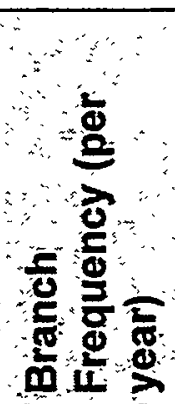 & 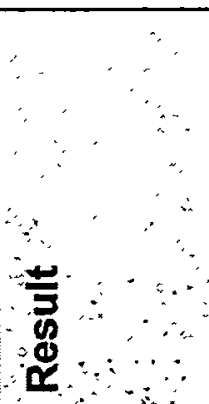 \\
\hline A & .1 & .95 & $5 \times 10^{-3}$ & .01 & .1 & .1 & .7 & $3.5 \times 10^{-8}$ & $\begin{array}{l}\text { Release } \\
\text { occurs }\end{array}$ \\
\hline B & .1 & .95 & $5 \times 10^{-3}$ & .01 & .1 & .1 & .3 & $1.5 \times 10^{-8}$ & No release \\
\hline C & .1 & .95 & $5 \times 10^{-3}$ & .01 & .1 & .9 & - & $4.5 \times 10^{-7}$ & No release \\
\hline$D$ & .1 & .95 & $5 \times 10^{-3}$ & .01 & .9 & - & - & $4.5 \times 10^{-6}$ & No release \\
\hline$E$ & .1 & .95 & $5 \times 10^{-3}$ & .99 & - & - & - & $4.5 \times 10^{-4}$ & No release \\
\hline$F$ & .1 & .95 & .995 & - & - & - & - & .1 & No release \\
\hline G & .1 & .05 & - & .01 & .1 & $: 1$ & .7 & $3.5 \times 10^{-7}$ & $\begin{array}{l}\text { Release } \\
\text { occurs }\end{array}$ \\
\hline$H$ & .1 & .05 & - & .01 & .1 & .1 & .3 & $1.5 \times 10^{-7}$ & No release \\
\hline 1 & .1 & .05 & - & .01 & .1 & .9 & - & $4.5 \times 10^{-6}$ & No release \\
\hline$J$ & .1 & .05 & - & .01 & .9 & - & - & $4.5 \times 10^{-5}$ & No release \\
\hline$k$ & .1 & .05 & - & .99 & - & - & - & $.5 \times 10^{-2}$ & No release \\
\hline
\end{tabular}

* The probabilities in Table 3-C-1 must be interpreted in conjunction with the yes/no branches in Figure 3C-1. Numbers in normal font represent the probability that the statement is true, while bold italics represent the probability that the statement in the column heading is not true. 


\section{3-C.2 Fire InSide Hot Cell-Autoignition Of ReActive METALS}

\section{3-C.2.1 Accident Sequence Development}

This DBA is defined as a fire inside the hot cell, fueled by autoignition of reactive metals until the self-sustaining temperature for $\mathrm{Pu}$ combustion is reached, resulting in release of material or waste radioactive components. This is Scenario F1, Event 3, in Appendix 3-B.

\section{Initiating Event:}

1. Autoignition of reactive metals.

No credit is taken for limited inventories of radioactive material associated with sodium in the known materials and wastes.

Preventive Controls:

1. Administrative controls on processing of sodium.

Mitigative Controls:

1. Administrative controls that prohibit leaving sodium unattended in open containers.

2. Manual system for fire suppression.

3. Alarms (fire detectors) in ventilation ducts.

4. Emergency response training for workers.

No credit is taken for retention of particulates by the HEPA filters.

The DBA accident progression is defined as follows:

1. Waste or materials arrives containing sodium.

2. Administrative controls fail, and sodium is exposed directly to ambient air.

3. Humidity in the air ignites the sodium.

\section{3-C.2.2 Accident Sequence and Frequency Analysis}

For this DBA, the undesired event is release of radioactive component of materials or wastes. Failure frequencies for the various nodes were developed from Mahn et al. (1995) and DOE (1996) or by expert judgment of the analysts. The ET analysis diagram is shown in Figure 3-C-2. The outcomes of the ET analysis in Figure 3-C-2 are shown as four branches. The outcomes represent the following accident scenarios. 
- Branch A: An administrative control fails. Sodium ignition occurs from humidity in the air, manual fire suppression fails, and the radioactive component of the waste is released.

- Branch B: An administrative control fails. Sodium ignition occurs from humidity in the air, but the fire is successfully extinguished. No release occurs.

- Branch C: An administrative control fails, but the humidity is low. No ignition occurs.

- Branch D: Administrative controls are successful. No release occurs.

Failure probabilities for the various initiating events in the ET analysis are as follows:

- Event 1: Waste contains sodium. A small percentage of the existing waste packages contain sodium. For the sake of conservatism, sodium is considered to occur 4 times a year for the lifetime of the facility. All packages are conservatively assumed to require processing.

- Event 2: Administrative controls fail. DOE (1996) considered failure of administrative controls to occur with a frequency of $5 \times 10^{-3}$ per event based on best engineering judgment.

- Event 3: Ignition occurs from humidity in the ambient air. This is considered an off-normal event and given a probability of 0.01 based on best engineering judgement.

- Event 4: Manual fire suppression is unsuccessful. DOE (1996) estimated the probability of failure of manual fire suppression as .01 . Sodium will not be left unattended in open containers.

The frequency of each operational outcome or branch for the event tree of Figure 3-C-2 is shown in Table 3-C-2. The probabilities in Table 3-C-2 must be interpreted in conjunction with the yes/no branches in Figure 3-C-2.

\section{3-C.2.3 Comparison of Accident Frequency from ET Analysis to the Hazard Evaluation Results}

The accident analysis shows that the expected accident probability (Table 3-C-2) is much less than the hazard evaluation (Tables 3-5 and 3-6) originally suggested. The accident is determined to be very unlikely, primarily because of process controls on $\mathrm{Na}$ handling and because of required fire surveillance and manual fire suppression available in the hot cell. 


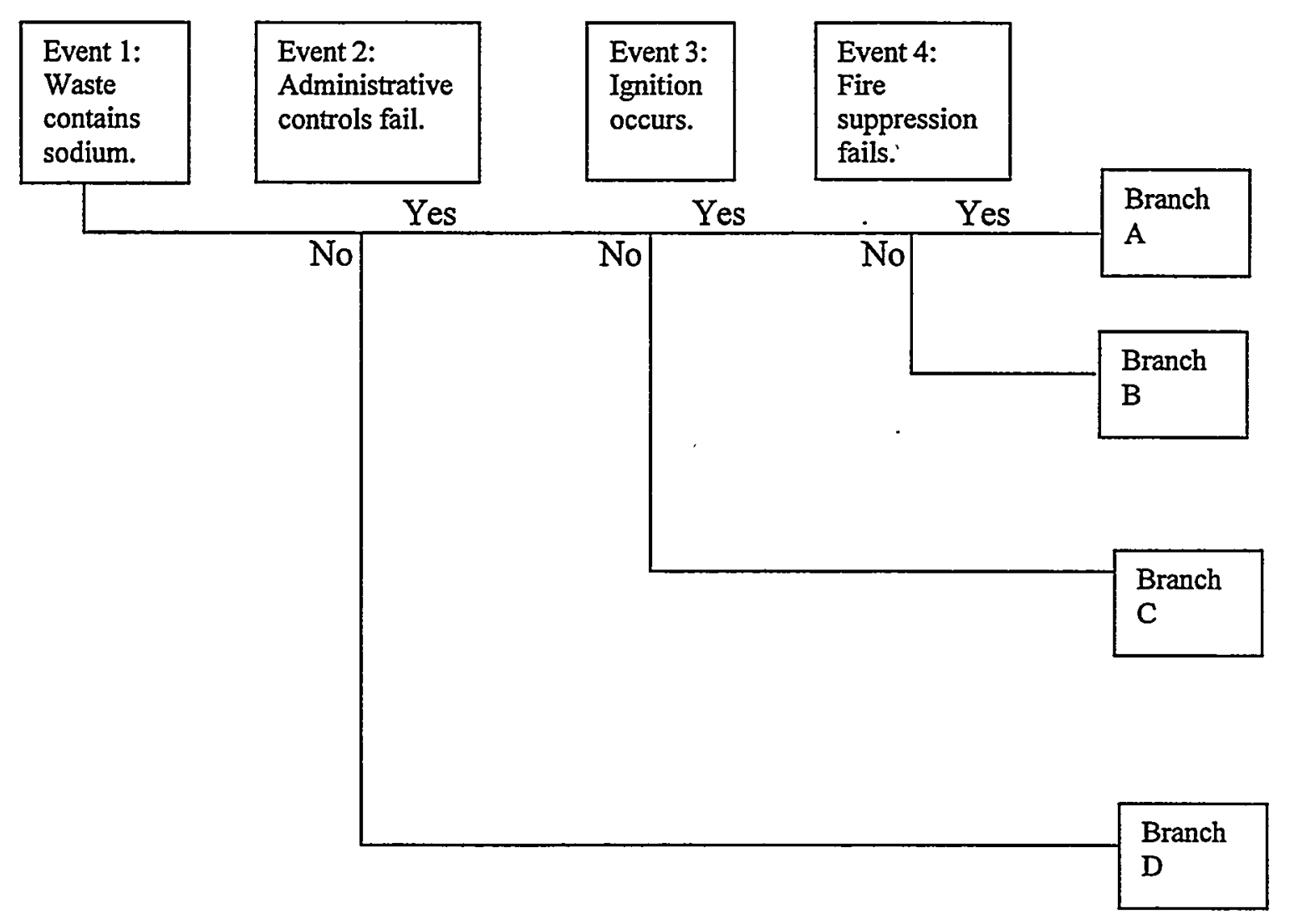

Figure 3-C-2. ET Analysis Diagram - DBA for Fire Inside Hot CellAutoignition of Reactive Metals.

Table 3-C-2. Frequency of Occurrence Outcomes for Each Branch of the ET Analysis Diagram - DBA for Fire Inside Hot Cell-Autoignition of Reactive Metals

\begin{tabular}{|c|c|c|c|c|c|c|}
\hline$\frac{\frac{2}{0}}{\frac{0}{0}}$ & 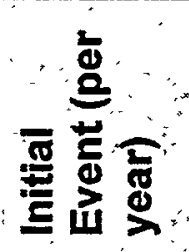 & $\begin{array}{l}0 \\
0 \\
0\end{array}$ & $\frac{1}{0}$ & 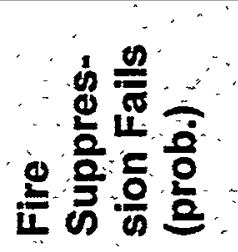 & $\frac{\frac{5}{0}}{0}$ & 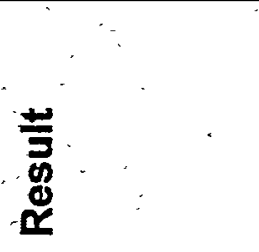 \\
\hline A & 4 & $5 \times 10^{-3}$ & .01 & .01 & $2 \times 10^{-6}$ & Release occurs \\
\hline B & 4 & $5 \times 10^{-3}$ & .01 & .99 & $2 \times 10^{-4}$ & No release \\
\hline C & 4 & $5 \times 10^{-3}$ & .99 & - & $2 \times 10^{-2}$ & No release \\
\hline D & 4 & .995 & - & - & 4 & No Release \\
\hline
\end{tabular}

* The probabilities in Table 3-C-2 must be interpreted in conjunction with the yes/no branches in Figure 3$\mathrm{C}-2$. Numbers in normal font represent the probability that the statement is true, while bold italics represent the probability that the statement in the column heading is not true. 


\section{3-C.3 Fire OUTSIDE Hot Cell-Vehicular EquipMent MALFUNCTION}

\section{3-C.3.1 Accident Sequence Development}

This DBA is defined as a fire in the High Bay, initiated by malfunction associated with a vehicle, such as a forklift, moving material or waste. The fire burns until the selfsustaining temperature for $\mathrm{Pu}$ combustion is reached, resulting in release of material or waste radioactive components. This is Scenario F2, Event 2A, in Appendix 3-B.

Initiating Event:

Fire from vehicular equipment malfunction.

Preventive Controls:

1. Regular maintenance on vehicles.

2. Vehicle operator training.

Mitigative Controls:

1. Building fire suppression system.

2. Fire suppression training.

3. Strong, fire-resistant packaging.

4. Emergency response training.

The DBA accident progression is defined as follows:

1. Equipment associated with a vehicle transporting material or waste malfunctions. This could include catastrophic battery failure or leaking of hydraulic/brake fluid onto hot brake surface.

2. Building fire suppression system fails.

3. Fire reaches the waste package and burns until the self-sustaining temperature for plutonium combustion is reached.

\section{3-C.3.2 Accident Sequence and Frequency Analysis}

For this DBA, the undesired event is release of radioactive component of materials or wastes. Failure frequencies for the various nodes were developed from Mahn et al. (1995) and DOE (1996) or by expert judgment of the analysts. The ET analysis diagram is shown in Figure 3-C-3. The outcomes of the ET analysis in Figure 3-C-3 are shown as four branches. The outcomes represent the following accident scenarios:

- Branch A: A vehicular fire occurs. Both manual fire suppression and the building fire suppression system fail. The radioactive component of the waste is released. 
- Branch B: A vehicular fire occurs. Manual fire extinction is unsuccessful, but the building fire suppression extinguishes the fire. No release occurs.

- Branch C: A vehicular fire occurs, but the fire is successfully manually extinguished. No release occurs.

- Branch D: No vehicular fire occurs.

Failure probabilities for the various initiating events in the ET analysis are as follows:

- Event 1: Vehicles move waste. Vehicles are assumed to move waste 400 times per year.

- Event 2: Vehicular fire occurs. This assumes a vehicular fire rate of $1 \times 10^{-5}$ based on best engineering judgement.

- Event 3: Manual fire suppression by operator is unsuccessful. Assumes manual fire suppression failure of $1 \times 10^{-2}$ (DOE 1996).

- Event 4: Building fire suppression fails. Best engineering judgment estimates probability of failure of automatic fire suppression to be $1 \times 10^{-6}$. This was increased by a factor of 10 for the purposes of this analysis because of the high ceilings in the High Bay.

The frequency of each operational outcome or branch for the event tree of Figure 3-C-3 is shown in Table 3-C-3. The probabilities in Table 3-C-3 must be interpreted in conjunction with the yes/no branches in Figure 3-C-3.

\section{3-C.3.3 Comparison of Accident Frequency from ET Analysis to the Hazard Evaluation Results}

The accident analysis shows that the expected accident probability (Table 3-C-3) is much less than the hazard evaluation (Tables 3-5 and 3-6) originally suggested. The accident is determined to be incredible because of operator training on application of manual fire suppression and the reliability of building fire suppression. 


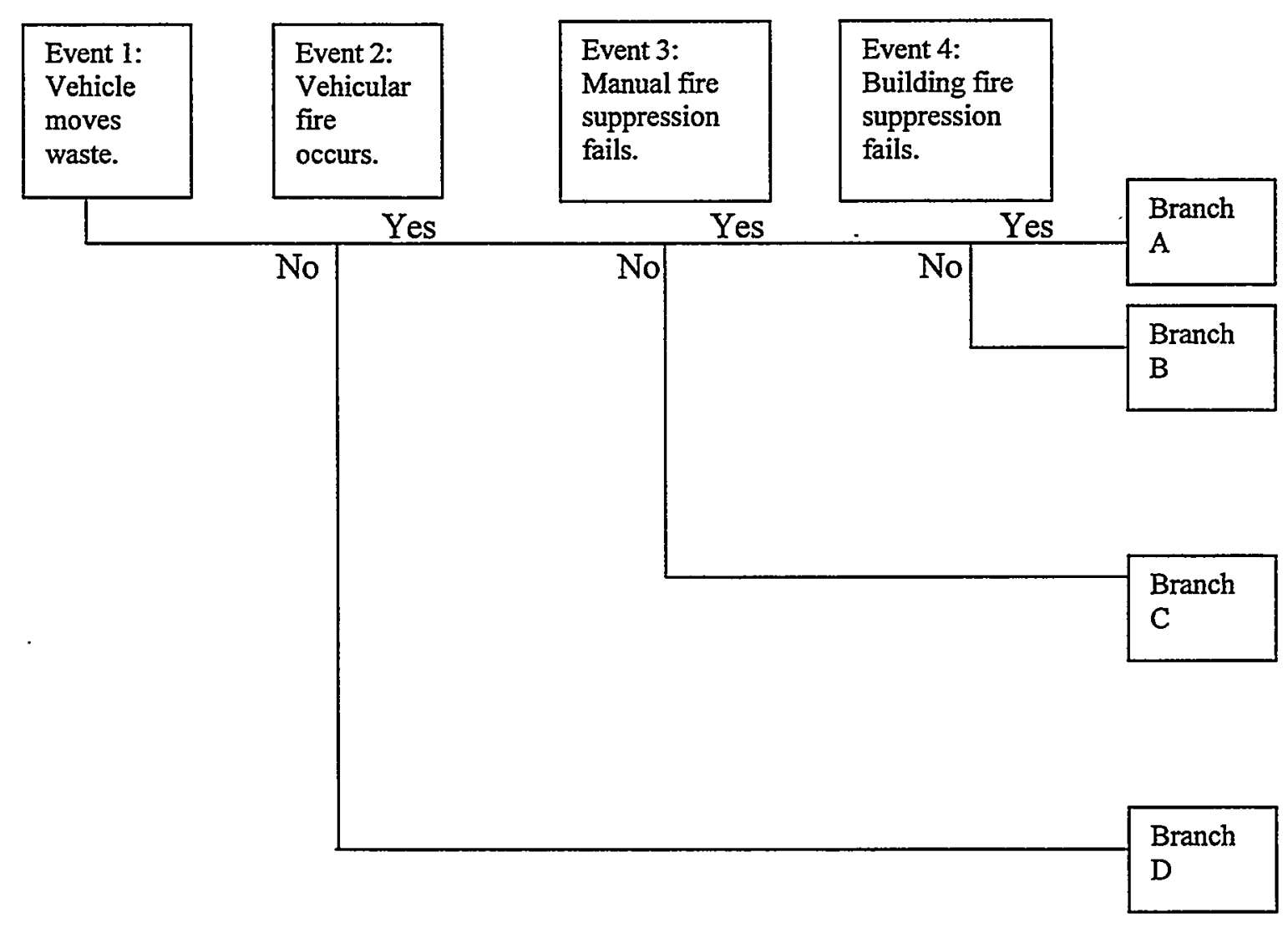

Figure 3-C-3. ET Analysis Diagram - DBA for Fire Outside Hot CellVehicular Equipment Malfunction.

Table 3-C-3. Frequency of Occurrence Outcomes for Each Branch of the ET Analysis Diagram - DBA for Fire Outside Hot Cell-Vehicular Equipment Malfunction

\begin{tabular}{|c|c|c|c|c|c|c|}
\hline$\frac{5}{0}$ & 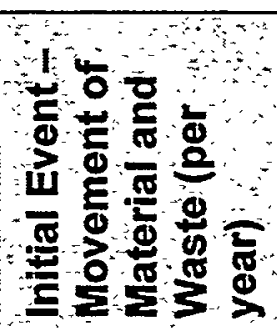 & 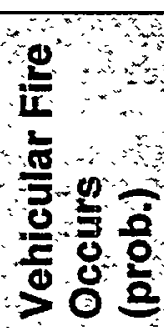 & 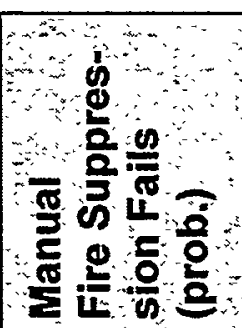 & 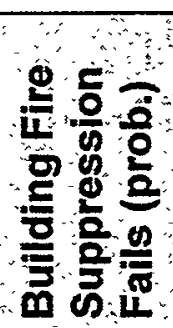 & $\begin{array}{l}\frac{0}{0} \\
\frac{0}{0} \\
0 \\
0\end{array}$ & $\begin{array}{l} \\
\vdots \\
0\end{array}$ \\
\hline A & 400 & $1 \times 10^{-5}$ & $1 \times 10^{-2}$ & $1 \times 10^{-5}$ & $4 \times 10^{-10}$ & Release occurs \\
\hline B & 400 & $1 \times 10^{-5}$ & $1 \times 10^{-2}$ & .99999 & $4 \times 10^{-5}$ & No release \\
\hline $\mathrm{C}$ & 400 & $1 \times 10^{-5}$ & .99 & - & $4 \times 10^{-3}$ & No Release \\
\hline D & 400 & .99999 & - & - & 400 & No Release \\
\hline
\end{tabular}

* The probabilities in Table 3-C-3 must be interpreted in conjunction with the yes/no branches in Figure 3$\mathrm{C}-3$. Numbers in normal font represent the probability that the statement is true, while bold italics represent the probability that the statement in the column heading is not true. 


\section{3-C.4 EARTHQUAKe INITIATES Fire OUtSide Hot Cell}

\section{3-C.4.1 Accident Sequence Development}

This DBA is defined as a fire in the High Bay initiated as a result of an earthquake. This is Scenario F2, Event 3a, in Appendix 3-B.

Initiating Event:

1. Earthquake leads to deflagration of natural gas in the High Bay.

Preventive Controls:

1. Strong, tight containers.

2. Administrative controls limiting flammable materials in the High Bay.

Mitigative Controls:

1. Emergency response, including evacuation procedures.

The DBA accident progression is defined as follows:

1. Design basis earthquake occurs.

2. The building collapses on the containers and releases the contents.

3. Collapse of the building causes breakage of natural gas lines.

4. Natural gas supply remains uninterrupted; natural gas is released.

5. Electrical power is uninterrupted, and electrical ignition sources cause deflagration of natural gas.

6. A fire occurs, sustained by flammable and combustible material in the building.

7. The building fire protection system is damaged by the earthquake and fails to function.

8. Plutonium reaches the self-sustaining temperature for combustion.

\section{3-C.4.2 Accident Sequence and Frequency Analysis}

For this DBA, the undesired event is release of the radioactive component of materials or wastes. Failure frequencies for the various nodes were developed from Mahn et al. (1995) and DOE (1996) or by expert judgment of the analysts. The ET analysis diagram is shown in Figure 3-C-4. The outcomes of the ET analysis in Figure 3-C-4 are shown as four branches. The outcomes represent the following detailed accident occurrence scenarios.

- Branch A: Design basis earthquake occurs. The building collapses on the containers and releases the contents. Collapse of the building causes breakage of natural gas lines. Natural gas supply remains uninterrupted; natural gas is released. Electrical power supply remains uninterrupted, and electrical ignition sources ignite a deflagration of natural gas. A fire occurs, sustained by flammable 
and combustible material in the building. The building fire protection system is damaged by the earthquake and fails to function. Plutonium reaches the selfsustaining temperature for combustion.

- Branch B: The building collapses on the containers and releases the contents. Collapse of the building causes breakage of natural gas lines. Natural gas supply remains uninterrupted; natural gas is released. Electrical power supply remains uninterrupted, and electrical ignition sources cause deflagration of natural gas. However, combustible/flammable loading in the building is insufficient to sustain a fire. No release occurs.

- Branch C: The building collapses on the containers and releases the contents. Collapse of the building causes breakage of natural gas lines. Natural gas supply remains uninterrupted; natural gas is released. No deflagration of natural gas occurs, either because the electrical supply is disrupted by the earthquake or because there is no longer a structure to contain the gas at LEL concentrations.

- Branch D: The building collapses on the containers and releases the contents. Collapse of the building causes breakage of natural gas lines. Natural gas supply has been interrupted by the earthquake. No natural gas is released. No release occurs.

Failure probabilities for the various initiating events in the ET analysis are as follows:

- Event 1: A design basis earthquake occurs. A design basis earthquake is expected to occur with an annual frequency of $7 \times 10^{-4}$. Collapse of building and release of radioactive inventory from the containers is assumed.

- Event 2: Natural gas is released. Natural gas lines extend to the Mid Bay. Collapse of the wall separating Mid Bay and High Bay is assumed. A design basis earthquake could be sufficiently devastating to interrupt natural gas lines. Probability that the gas supply remains intact is set at .5.

- Event 3: Natural gas deflagrates. A spark could occur from dislodged electric wires from the crane, the cameras, etc. However, the electrical supply could be interrupted by the earthquake. Also, if the building collapses, buildup of LEL concentrations of gas is unlikely. Probability of this event is set at .5.

- Event 4: A fire occurs. All these scenarios assume that the building has collapsed, and therefore there is no structure to retain the natural gas, making the initiation of fire by deflagration less likely. However, if a fire starts, it could be sustained by flammable and combustible material in the building. The building fire protection system is damaged by the earthquake and fails to function. Administrative controls will limit flammable inventory in the building. However, combustible loading in the storage portion of the High Bay is not controlled. Probability of this event is set at.1. 


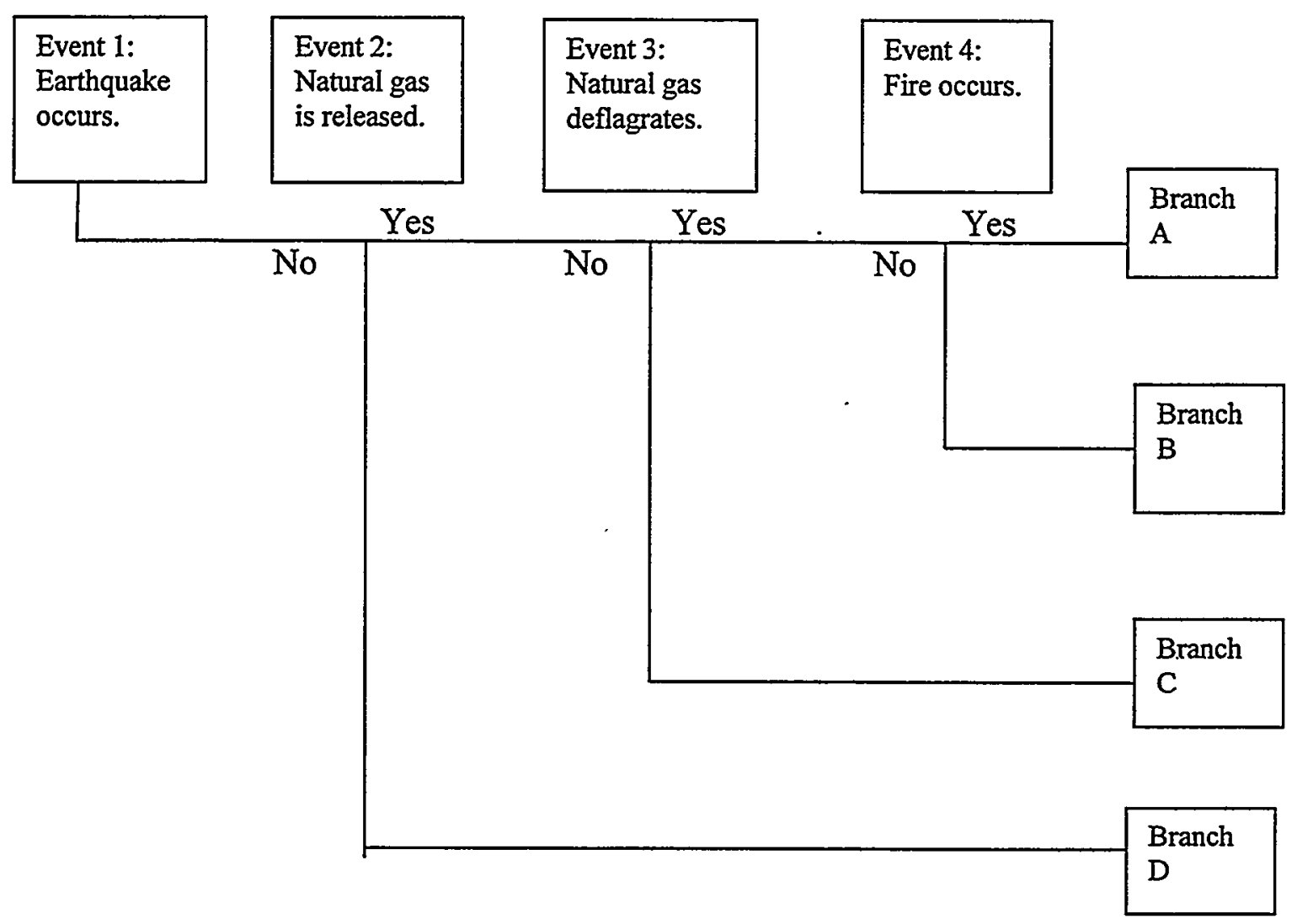

Figure 3-C-4. ET Analysis Diagram - DBA for Earthquake Initiating Fire Outside Hot Cell. 
Table 3-C-4. Frequency of Occurrence Outcomes for Each Branch of the ET Analysis Diagram - DBA for Earthquake Initiating Fire Outside Hot Cell

\begin{tabular}{|c|c|c|c|c|c|c|c|}
\hline 需 & 嵌 & 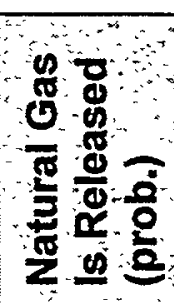 & 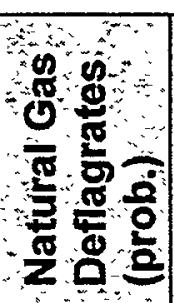 & $\begin{array}{l}0 \\
0 \\
0 \\
0 \\
0\end{array}$ & 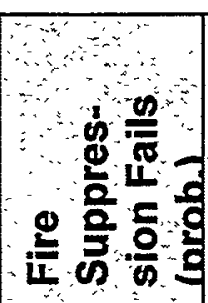 & 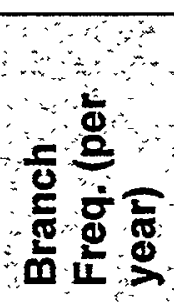 & 㟧 \\
\hline A & $7 \times 10^{-4}$ & .5 & .5 & .1 & 1 & $1.8 \times 10^{-5}$ & Release occurs \\
\hline B & $7 \times 10^{-4}$ & .5 & .5 & .9 & - & $1.8 \times 10^{-4}$ & No release \\
\hline $\bar{c}$ & $7 \times 10^{-4}$ & .5 & .5 & - & - & $3.5 \times 10^{-4}$ & No release \\
\hline $\bar{D}$ & $7 \times 10^{-4}$ & .5 & & & & $7 \times 10^{-4}$ & No release \\
\hline
\end{tabular}

* The probabilities in Table 3-C-4 must be interpreted in conjunction with the yes/no branches in Figure 3C-4. Numbers in normal font represent the probability that the statement is true, while bold italics represent the probability that the statement in the column heading is not true.

The frequency of each operational outcome or branch for the event tree in Figure 3-C-4 is shown in Table 3-C-4. The probabilities in Table 3-C-4 must be interpreted in conjunction with the yes/no branches in Figure 3-C-4.

\section{3-C.4.3 Comparison of Accident Frequency from ET Analysis to the Hazard Evaluation Results}

The accident analysis shows that the expected accident probability (Table 3-C-4) is much less than the hazard evaluation (Tables 3-5 and 3-6) originally suggested. The accident is considered very unlikely, primarily because of the potential for the earthquake to disrupt the natural gas and electrical supplies. 


\section{3-C.5 DEFLAGRATION INSIDE HOT CELL-IGNITION OF FLAMMABLE GAS}

\section{3-C.5.1 Accident Sequence Development}

This DBA is defined as a deflagration inside the hot cell from a flammable gas, resulting in release of Pu-239 as a respirable powder. This is Scenario De1, Event 1B, in Appendix 3-B.

Initiating Event:

1. Deflagration of flammable gas inside hot cell.

Sparks from electrical switches or controls could provide an ignition source. The ventilation system would dilute the flammable gas, but the exhaust fan is a likely ignition source. Because the event is assumed to occur rapidly, no credit is taken for manual fire suppression.

Preventive Controls:

1. Regular maintenance on electrical equipment.

2. Administrative controls on the waste types allowed in the hot cell, limiting flammable gases below the amounts needed to initiate deflagration, set at $25 \%$ of lower explosion limits.

3. Procedures for package inspection.

\section{Mitigative Controls:}

1. Alarms (fire detectors) in ventilation ducts.

2. Emergency response training for workers.

No credit is taken for retention of particulates by the HEPA filters.

The DBA accident progression is defined as follows:

1. Waste or materials is presented with flammable gas components.

2. Greater than LEL quantities of flammable gas are allowed in the hot cell due to failure of administration controls or lack of information regarding the waste package (lack of process knowledge and/or unrecognizable waste form on $\mathrm{x}$-ray).

3. The flammable component is released from the package through leak or operator error.

4. Sparks from electrical equipment ignite the material. 


\section{3-C.5.2 Accident Sequence and Frequency Analysis}

For this DBA, the undesired event is release of radioactive component of materials or wastes. Failure frequencies for the various nodes were developed from Mahn et al. (1995) and DOE (1996) or by expert judgment of the analysts. The ET analysis diagram is shown in Figure 3-C-5. The outcomes of the ET analysis in Figure 3-C-5 are shown as nine branches. The outcomes represent the following detailed accident occurrence scenarios.

- Branch A: Flammable gas is a known constituent of the wastes. However, administrative controls fail to prevent material in excess of set limits from entering the hot cell. The flammable gas becomes available to an ignition source due to leaks or normal processing. Deflagration occurs and the radioactive component of the waste is released.

- Branch B: Flammable gas is a known constituent of the wastes. However, administrative controls fail to prevent the material from entering the hot cell. The flammables become available to an ignition source due to leaks or normal processing. However, the material fails to ignite and no release occurs.

- Branch C: Flammable gas is a known constituent of the wastes. However, administrative controls fail to prevent the material from entering the hot cell. The flammable gas becomes available to an ignition source due to leaks or normal processing. However, none of the electrical components spark, and there is no ignition source. No release occurs.

- Branch D. Flammable gas is a known constituent of the wastes. However, administrative controls fail to prevent the material from entering the hot cell. The flammable gas remains containerized and unavailable to ignition sources. No release occurs.

- Branch E: Flammable gas is a known constituent of the materials or wastes. Administrative controls successfully prevent the materials or waste from entering the hot cell. No release occurs.

- Branch F: Flammable gas is an unknown constituent of the wastes. The flammables become available to an ignition source due to leaks or normal processing. Deflagration occurs and the radioactive component of the waste is released.

- Branch G: Flammable gas is an unknown constituent of the wastes. The gas becomes available to an ignition source due to leaks or normal processing. An ignition source is available but the gas fails to ignite. No release occurs. 
- Branch H: Flammable gas is an unknown constituent of the wastes. The gas becomes available to an ignition source due to leaks or normal processing. No ignition source is available for ignition. No release occurs.

- Branch I: Flammable gas is an unknown constituent of the waste. The gas remains containerized and is unavailable to an ignition source. No release occurs.

Failure probabilities for the various initiating events in the ET analysis are as follows:

- Event 1: Waste contains flammable gas. Flammable gases are not a constituent of existing SNL waste, but it is possible that gases will be received either as known or unknown constituent of waste. Conservatively assumed to occur once every 700 packages or every 10 years (.1 times a year).

- Event 2: Flammable gas is a known constituent of waste or its presence is indicted by the $x$-ray. Process knowledge on $95 \%$ of the packages allows identification of material or waste constituents. X-ray would indicate the presence of containers with unknown content. Probability of knowing waste contents estimated as .95 .

- Event 3: Administrative controls prevent admission of excessive amounts of flammable gas into the hot cell. DOE (1996) estimated the failure rate of administrative controls to be $5 \times 10^{-3}$.

- Event 4: Material is released from the package due to a leak or as part of processing. This probability was estimated as .1, although DOE (1996) estimated a lower probability for spills/leaks. The remote handling makes handling accidents more probable. Also, occasional processes may require venting of gas.

- Event 5: Ignition source is available. The most likely source would be sparks from electrical equipment. This is considered an off-normal event and conservatively set at 0.1 (DOE 1996).

- Event 6: Ignition occurs. If ignition source is weak or intermittent, the material may not ignite. Ignition probability set at 0.1 .

The frequency of each operational outcome or branch for the event tree of Figure 3-C-5 is shown in Table 3-C-5. The probabilities in Table 3-C-5 must be interpreted in conjunction with the yes/no branches in Figure 3-C-5. 


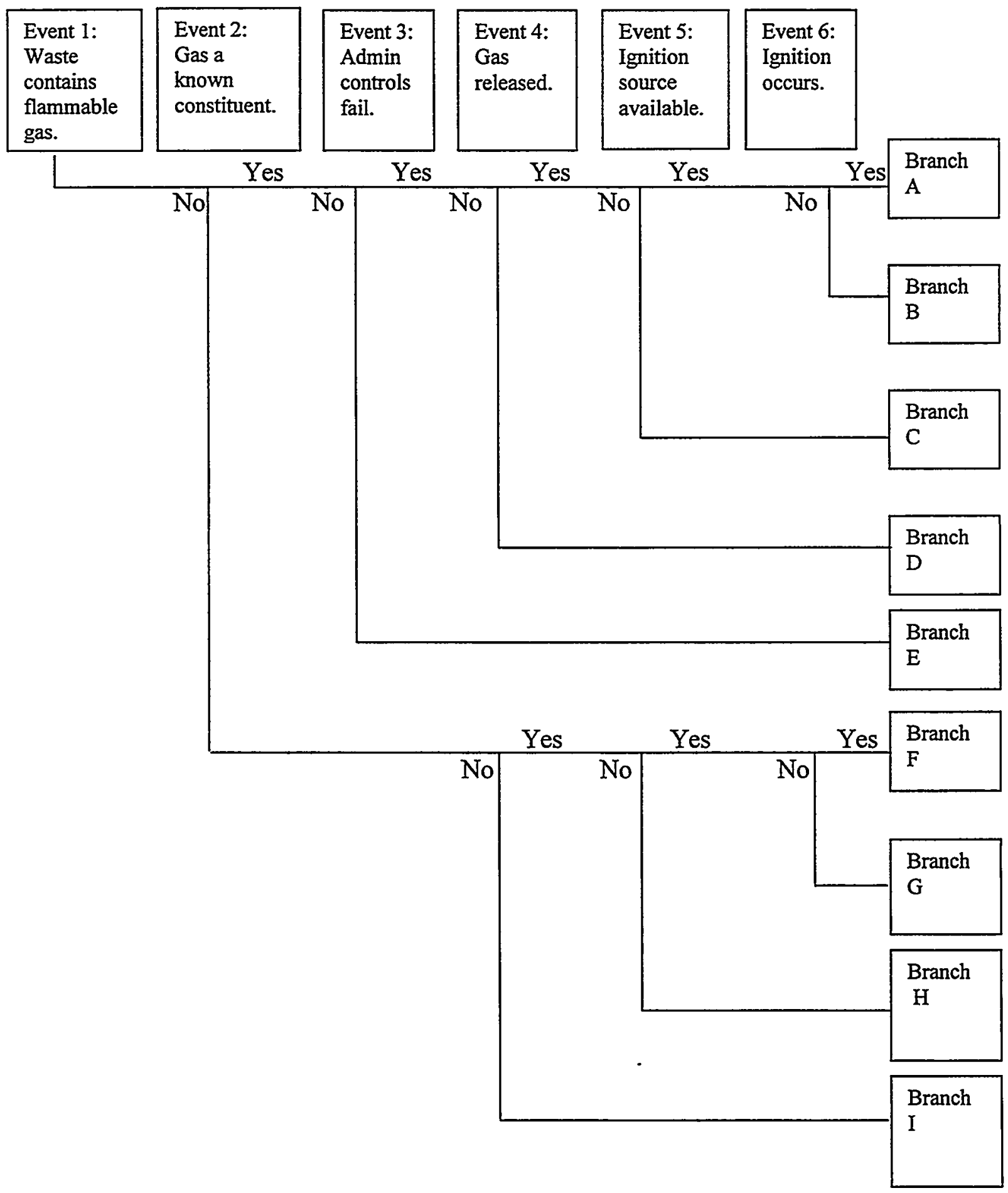

Figure 3-C-5. ET Analysis Diagram - DBA for Deflagration Inside Hot Cell-Ignition of Flammable Gas. 
Table 3-C-5. Frequency of Occurrence Outcomes for Each Branch of the ET Analysis Diagram - DBA for Deflagration Inside Hot Cell-Ignition of Flammable Gas

\begin{tabular}{|l|l|l|l|l|l|l|l|l|}
\hline & & & & & \\
\end{tabular}

\section{3-C.5.3 Comparison of Accident Frequency from ET Analysis to the Hazard Evaluation Results}

The accident analysis shows that the expected accident probability (Table 3-C-5) is much less than the hazard evaluation (Tables 3-5 and 3-6) originally suggested. The accident is determined to be incredible, primarily because of the infrequent appearance of flammable gas in the hot cell and administrative controls on the volume of gas to be admitted. 


\section{3-C.6 EXTERNAL EXPOSURE TO WORKER-FAILURE OF PASSIVE RADIATION SHIELDING}

\section{3-C.6.1 Accident Sequence Development}

This DBA is defined as a failure of passive radiation shielding resulting in radiation streaming and worker radiation exposure. This is Scenario EE1, Event 1, in Appendix 3-B.

Initiating Event:

1. Failure of passive radiation shielding.

Preventive Controls:

1. HP routine surveillance of the integrity of the hot cell.

2. Physical examination of the hot cell for window cracks, sand settling, etc.

\section{Mitigation:}

1. Radiation worker training.

2. Use of self-alarming personal dosimeters when appropriate.

3. Procedures delineating appropriate worker response to alarms.

The DBA accident progression is defined as follows:

1. Waste or materials are presented containing highly radioactive sources.

2. Hot cell develops physical breaches, resulting in worker exposure.

\section{3-C.6.2 Accident Sequence and Frequency Analysis}

For this DBA, the undesired event is worker exposure to radiation. Failure frequencies for the various nodes were developed from Mahn et al. (1995) and DOE (1996) or by expert judgment of the analysts. The ET analysis diagram is shown in Figure 3-C-6. The outcomes of the ET analysis in Figure 3-C-6 are shown as four branches. The outcomes represent the following accident scenarios:

- Branch A: Highly radioactive waste or material is presented. The hot cell develops a breach that allows radiation streaming, such as by settling of the sand. HP surveillance fails to detect the streaming. The self-alarming personal dosimeters fail and exposure occurs.

- Branch B: Highly radioactive waste or material is presented. The hot cell develops a breach. HP surveillance fails to detect the streaming; however, the self-alarming personal dosimeters activate, and workers evacuate. No significant exposure occurs. 
- Branch C: Highly radioactive waste or material is presented. The hot cell develops a breach, but HP surveillance detects the streaming. No exposure occurs.

- Branch D: Highly radioactive waste or material is presented, but the hot cell remains intact. No exposure occurs.

Failure probabilities for the various initiating events in the ET analysis are as follows:

- Event 1: Shielding fails. The failure of hot cell is considered analogous to glove box failures analyzed by DOE (1996) and estimated at .05/glove-box-year. In reality, the hot cell is expected to be much more robust than a glove box; thus this value is adjusted by a factor of .01 .

- Event 2: Failure of radiological surveillance. Probable cause either incorrect reading or recording data or miscalibration. Estimates in DOE (1996) of .01.

- Event 3: Worker response to self-alarming personal dosimeters inappropriate. This may be due to failure of personnel to use equipment as required or failure to respond to alarm. The most frequent estimate for human error is .01 (DOE 1996, Table B.4). The probability of inappropriate worker response is $1 \mathrm{x}$ $10^{-2}$. The equipment failure of the dosimeter is also possible, but much less probable than the inappropriate worker response (estimated $5 \times 10^{-6}$ per hour based on ion chamber sensor (DOE 1996).

The frequency of each operational outcome or branch for the event tree of 3-C-6 is shown in Table 3-C-6. The probabilities in Table 3-C-6 must be interpreted in conjunction with the yes/no branches in Figure 3-C-6. The accident is incredible because of Health Physics surveillance procedures and because of the use of self-alarming personal dosimeters.

\section{3-C.6.3 Comparison of Accident Frequency from ET Analysis to the Hazard Evaluation Results}

The accident analysis shows that the expected accident probability (Table 3-C-6) is much less than the hazard evaluation (Tables 3-5 and 3-6) originally suggested. 


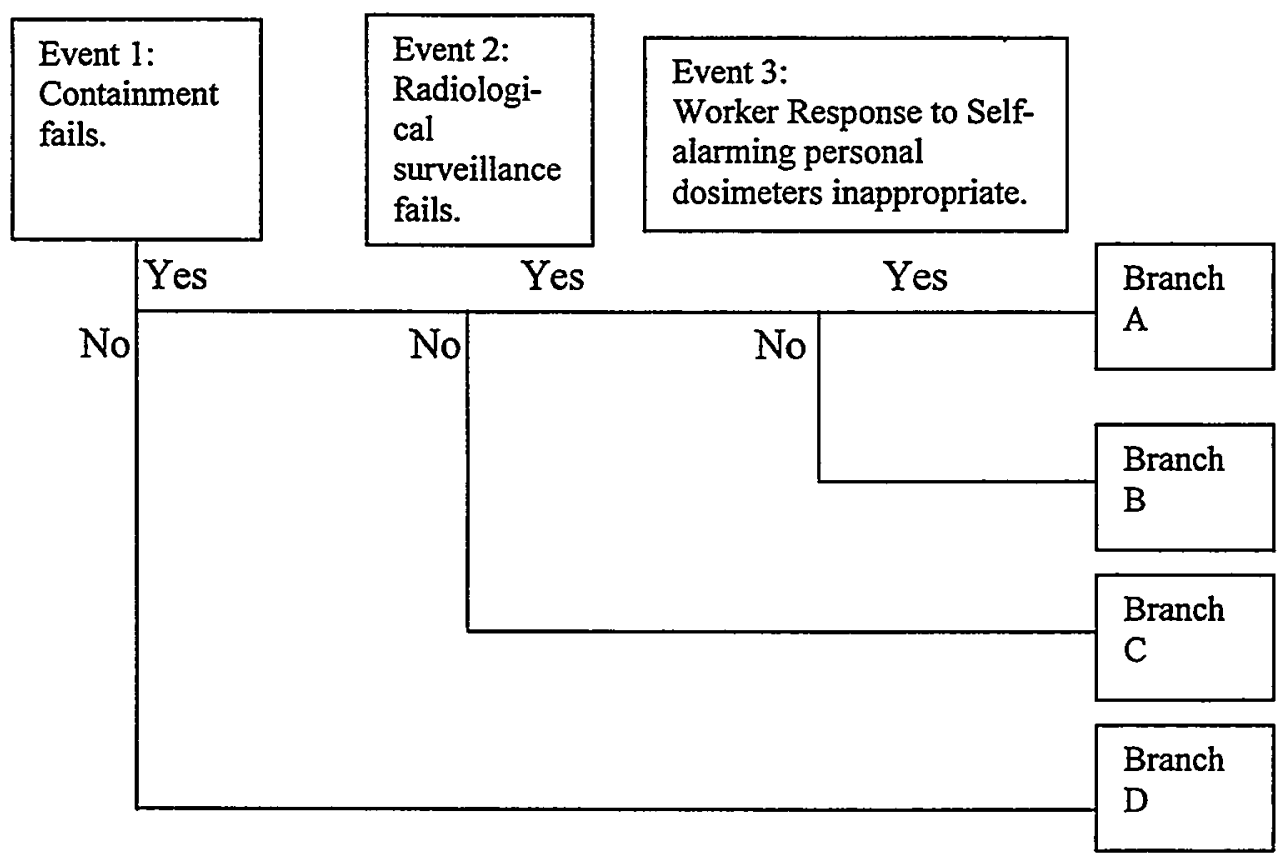

Figure 3-C-6. ET Analysis Diagram - DBA for External Exposure to Worker-Failure of Passive Radiation Shielding.

Table 3-C-6. Frequency of Occurrence Outcomes for Each Branch of the ET Analysis Diagram - DBA for External Exposure to Worker-Failure of Passive Radiation Shielding

\begin{tabular}{|c|c|c|c|c|c|}
\hline$\frac{5}{\frac{5}{0}}$ & 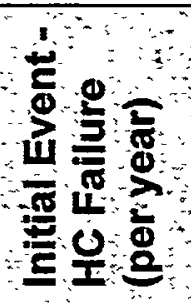 & 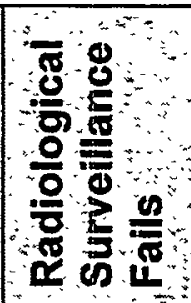 & 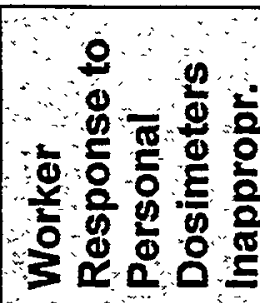 & 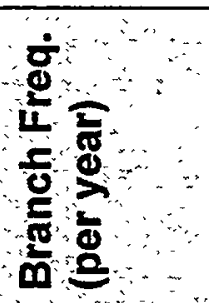 & 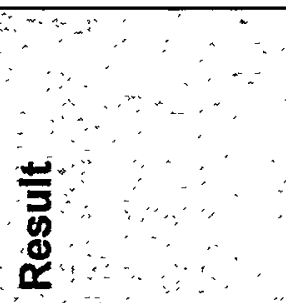 \\
\hline $\mathrm{A}$ & $5 \times 10^{-4}$ & .01 & $1 \times 10^{-2}$ & $5 \times 10^{-8}$ & Exposure Occurs \\
\hline$B$ & $5 \times 10^{-4}$ & .01 & .99 & $5 \times 10^{-6}$ & No Exposure \\
\hline C & $5 \times 10^{-4}$ & .99 & - & $5 \times 10^{-4}$ & No Exposure \\
\hline D & .9995 & - & - & .9995 & No Exposure \\
\hline
\end{tabular}

* The probabilities in Table 3-C-6 must be interpreted in conjunction with the yes/no branches in Figure 3C-6. Numbers in normal font represent the probability that the statement is true, while bold italics represent the probability that the statement in the column heading is not true. 


\section{3-C.7 EXTERNAL EXPOSURE TO WORKER - EXPOSED SOURCE AbOVE THE PERMANent SHIELD WALL}

\section{3-C.7.1 Accident Sequence Development}

This DBA is defined as an exposure of a colocated worker to an unshielded radioactive source. This is Scenario EE1, Event 3, in Appendix 3-B.

Initiating Events:

1. Source is suspended above the permanent shield wall as part of the placement into the hot cell.

2. A colocated worker approaches within 50 feet of the facility.

Preventive Controls:

1. Building 6597 is evacuated prior to source movement.

2. Backup provisions are made for a power failure.

3. Camera surveillance of area.

4. Physical spotters with line-of-sight contact monitor areas.

The DBA accident progression is defined as follows:

1. A source is exposed above the permanent shield wall.

2. Worker disregards access controls for building.

3. Camera surveillance fails.

4. Spotters fail to detect approach.

\section{3-C.7.2 Accident Sequence and Frequency Analysis:}

For this DBA, the undesired event is exposure of colocated worker to a radioactive source. Failure frequencies for the various nodes were developed from Mahn et al. (1995) and DOE (1996) or by expert judgment of the analysts. The outcomes of the ET analysis in Figure 3-C-7 are shown as nine branches. The outcomes represent the following detailed accident occurrence scenarios.

- Branch A: The source is hoisted above the permanent shield wall. The power fails and the backup generator fails. A colocated worker approaches the facility. The spotter fails to detect approach and exposure occurs.

- Branch B: The source is hoisted above the permanent shield wall. The power fails and the backup generator fails. A colocated worker approaches the facility. The spotter detects approach and exposure is prevented.

- Branch C: The source is hoisted above the permanent shield wall. The power fails and the backup generator fails. No colocated workers approach the facility. 
- Branch D: The source is hoisted above the permanent shield wall. The power remains on. A colocated worker approaches the facility. The cameras fail. The spotters fail to detect approach and exposure occurs.

- Branch E: The source is hoisted above the permanent shield wall. The power remains on. A colocated worker approaches the facility. The cameras remain operational but the operator fails to detect approach. The spotters detect approach. No exposure occurs.

- Branch F: The source is hoisted above the permanent shield wall. The power remains on. A colocated worker approaches the facility. The cameras remain operational but the operator fails to detect approach. Spotters fail to detect approach. Exposure occurs.

- Branch G: The source is hoisted above the permanent shield wall. The power remains on. A colocated worker approaches the facility. The cameras remain operational but the operator fails to detect approach. The spotters detect approach. No exposure occurs.

- Branch H: The source is hoisted above the permanent shield wall. The power remains on. A colocated worker approaches the facility. The cameras remain operational and the operator detects approach. No exposure occurs.

- Branch I: The source is hoisted above the permanent shield wall. The power remains on. No colocated worker approaches the facility. No exposure occurs.

Failure probabilities for the various initiating events in the ET analysis are as follows:

- Event 1: Source above shield wall. Conservatively assumed to occur 20 times a year. Movement time conservatively set at 5 minutes or 1.67 hours per year.

- Event 2: Power fails. Electrical power fails 3 times per year. Total operational time is 100 minutes per year ( 5 minutes $\times 20$ operations). Probability of a power failure each year during a transfer operation is equivalent to (100 minutes of operation)/ (525,600 minutes per year) of $2 \times 10^{-4}$. Probability of any one of three power failures during transfer is $6 \times 10^{-4}$. Probability of failure of the temporary generator is $1 \times 10^{-3} / \mathrm{hr} \times 1.67$ hours (100 minutes) $=2 \times 10^{-3}$. Probability of simultaneous power failure and failure of temporary generator is $6 \times 10^{-4} \times 2 \times 10^{-3}=$ $1.2 \times 10^{-6}$.

- Event 3: Worker fails to observe access controls. Human error set at $1 \times 10^{-2}$.

- Event 4: Cameras fail. General instrument failure rate is $3.3 \times 10^{-5}$ (DOE 1996). 


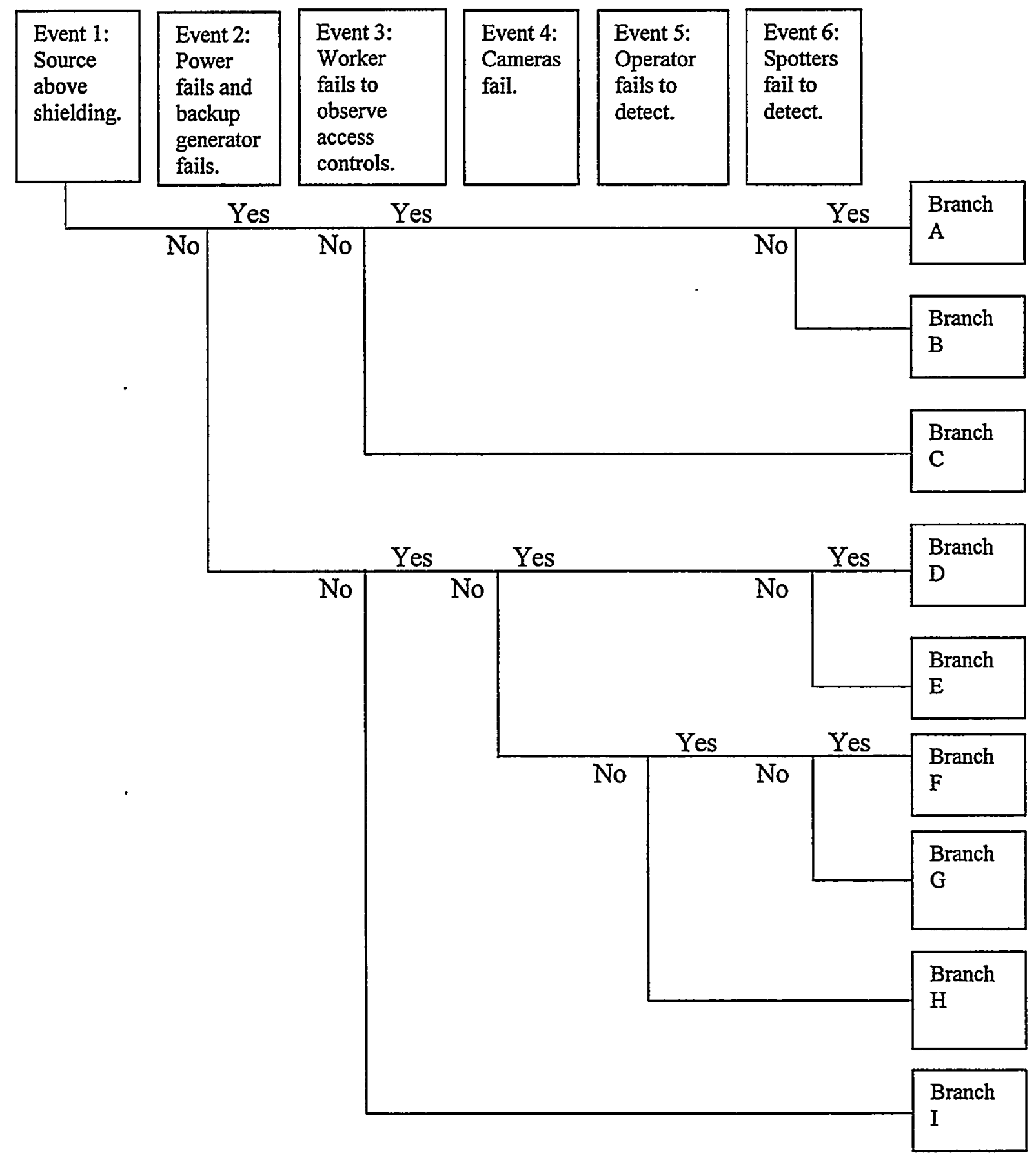

Figure 3-C-7. ET Analysis Diagram - DBA for External Exposure to Worker-Exposed Source Above Permanent Shield Wall. 
Table 3-C-7. Frequency of Occurrence Outcomes for Each Branch of the ET Analysis Diagram - DBA for External Exposure to Worker-Exposed Source Above Permanent Shield Wall

\begin{tabular}{|c|c|c|c|c|c|c|c|c|}
\hline $\begin{array}{l} \\
\frac{\mathbf{c}}{0} \\
\frac{\mathbf{c}}{\mathbf{m}}\end{array}$ & 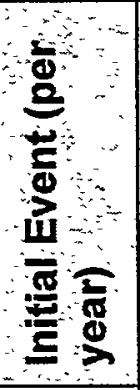 & 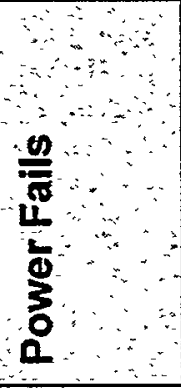 & 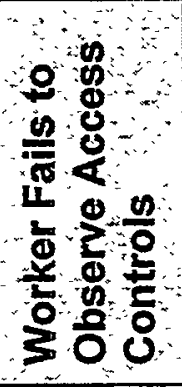 & 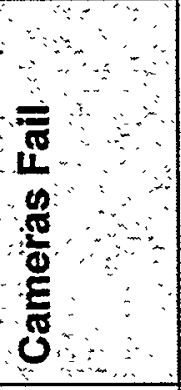 & 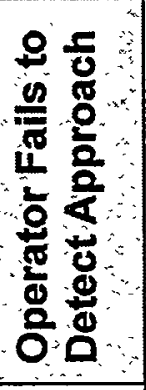 & 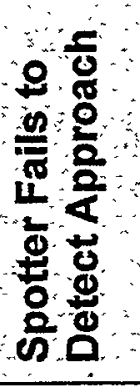 & 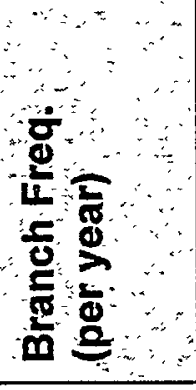 & 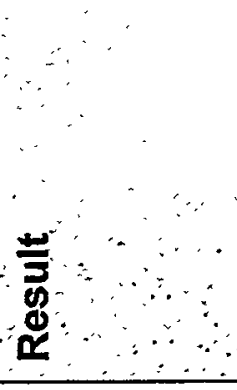 \\
\hline A & 20 & $1.2 \times 10^{-6}$ & $1 \times 10^{-2}$ & & & .01 & $2.4 \times 10^{-9}$ & $\begin{array}{l}\text { Exposure } \\
\text { occurs }\end{array}$ \\
\hline B & 20 & $1.2 \times 10^{-6}$ & $1 \times 10^{-2}$ & & & .99 & $2.4 \times 10^{-7}$ & No exposure \\
\hline C & 20 & $1.2 \times 10^{-6}$ & .99 & & & & $2.4 \times 10^{-5}$ & No exposure \\
\hline D & 20 & .999 & $1 \times 10^{-2}$ & $3.3 \times 10^{-5}$ & & .01 & $7 \times 10^{-8}$ & $\begin{array}{l}\text { Exposure } \\
\text { occurs }\end{array}$ \\
\hline$E$ & 20 & .999 & $1 \times 10^{-2}$ & $3.3 \times 10^{-5}$ & & .99 & $7 \times 10^{-6}$ & No exposure \\
\hline$F$ & 20 & .999 & $1 \times 10^{-2}$ & .99 & .01 & .01 & $2 \times 10^{-5}$ & $\begin{array}{l}\text { Exposure } \\
\text { occurs }\end{array}$ \\
\hline G & 20 & .999 & $1 \times 10^{-2}$ & .99 & .01 & .99 & $2 \times 10^{-3}$ & No exposure \\
\hline $\mathrm{H}$ & 20 & .999 & $1 \times 10^{-2}$ & .99 & .99 & & $2 \times 10^{-1}$ & No exposure \\
\hline 1 & 20 & .999 & .99 & & & & 20 & No exposure \\
\hline
\end{tabular}

* The probabilities in Table 3-C-7 must be interpreted in conjunction with the yes/no branches in Figure 3C-7. Numbers in normal font represent the probability that the statement is true, while bold italics represent the probability that the statement in the column heading is not true.

- Event 5: Operator fails to detect approach. Error of omission estimated at $1 \mathrm{x}$ $10^{-2}$ (DOE 1996).

- Event 6: Spotters fail to detect approach. Error of omission estimated at $1 \times 10^{-2}$ (DOE 1996).

The frequency of each operational outcome or branch for the event tree of Figure 3-C-7 is shown in Table 3-C-7. The probabilities in Table 3-C-7 must be interpreted in conjunction with the yes/no branches in Figure 3-C-7. 


\section{3-C.7.3 Comparison of Accident Frequency from ET Analysis to the Hazard Evaluation Results.}

The accident analysis shows that the expected accident probability (Table 3-C-7) is much less than the hazard evaluation (Tables 3-5 and 3-6) originally suggested. The accident is very unlikely because of the multiple mechanisms to detect approach of a worker into the radiation area.

\section{3-C.8 Chemical Release}

The release, by any mechanism, of the maximum allowable quantity of a Process Safety Management (29 CFR 1910.119) chemical from the AHCF is assumed. The consequences are bounded by the release of 60 pounds of hydrogen fluoride gas (25\% of PSM quantities).

Dispersion analysis indicates that ERPG-2 levels of HF gas would extend only 271 feet from Building 6597 (Walker 1999). This is well within the exclusion area boundary, $3000 \mathrm{~m}$ away. In accordance with the guidance provided by DOE (1997), no further analysis of chemical dispersion will be done.

\section{3-C.9 REFERENCES}

(DOE 1997) U.S. Department of Energy, "Hazard Categorization and Accident Analysis Techniques for Compliance with DOE Order 5480.23, Nuclear Safety Analysis Reports," DOE-STD-1027-92, Change Notice No. 1, U.S. Department of Energy, Washington, DC, 1997.

(DOE 1996) U.S. Department of Energy, "Hazard and Barrier Analysis Guidance Document," Rev. 0, DOE/EH-33, Office of Operating Experience Analysis and Feedback, U.S. Department of Energy, Washington, DC, November 1996.

(ICBO 1997) International Conference of Building Officials, "1997 Uniform Building Code," International Conference of Building Officials, Whittier, California, April 1997.

(Mahn et al. 1995) Mahn, Jeffrey A., G. William Hannaman, and Paul Kryska, "Qualitative Methods for Assessing Risk," SAND95-0320, Sandia National Laboratories, Albuquerque, NM, April 1995.

(Walker 1999) Walker, Sharon, "Results of Dispersion Analysis for Accidental Chemical Release from Building 6597, Sandia National Laboratories," Internal Memorandum, Sandia National Laboratories, Albuquerque, NM, July 21, 1999. 


\section{APPENDIX 3-D}

\section{EXTERNAL EVENTS SCREENING ASSESSMENT}

This appendix presents the potential external events that are considered in the hazard analysis of the AHCF. From this list of events, a screening assessment was performed to eliminate from further consideration any events that posed little or no hazard. The events that were not eliminated were analyzed more closely as part of the qualitative analyses contained in Appendix 3-C.

Potential external events were identified by reviewing previous Safety Analysis Reports of similar DOE facilities (Restrepo 1995) and the recommended list of external events used to evaluate commercial nuclear power plant risks (NRC 1983). In addition, an attempt was made to identify any other potential external initiating event unique to the site that had not been considered in previous studies. Operational accidents (e.g., criticality, internal fires) occurring inside the AHCF are not considered in this screening process. These types of "internal" initiating events are identified separately using preliminary hazard checklists (Appendix 3-A).

Table 3-D-1 presents the events that were considered for the AHCF. The "Screening Results" column summarizes how each event was categorized in the screening process. Four criteria are used in the screening process.

- Category 1. The event is impossible or highly improbable due to the size or location of the AHCF; the characteristics of the regional geography, topography, or hydrology; or the nature of the materials handled or the operations performed.

- Category 2. The event produces stresses that are similar to or less severe than other events under consideration.

- Category 3. The event would not result in any potential for adverse consequences to people at the site boundary.

- Category 4. The event could not be eliminated from consideration by screening; some level of qualitative or quantitative analysis is required.

Most events listed in Table 3-D-1 were eliminated from further consideration in this PSAR. (Some events were eliminated based on multiple criteria.) This does not mean they are all eliminated from all further consideration in the AHCF SAR. Earthquakes are considered in Appendix 3-C, "DBA Event Tree Analyses."

The events considered in this assessment, along with brief descriptions of their screening rationale, are listed below. 
Table 3-D-1. Potential External Events

\begin{tabular}{|c|c|c|}
\hline${ }^{\prime} \quad \therefore$ External Event $:-\cdots$ & Category & Screening Results \\
\hline Aircraft Impacts & 4 & Retained for further consideration. \\
\hline Avalanches/Landslides & 1 & Not possible or plausible at this site. \\
\hline Chemical/Toxic Gas Releases & 3 & No potential for adverse consequences. \\
\hline Coastal Erosion & 1 & Not possible or plausible at this site. \\
\hline Criticality Events & 1 & Not possible or plausible at this site. \\
\hline Drought & 3 & No potential for adverse consequences. \\
\hline Earthquake & 2,4 & $\begin{array}{l}\text { Less severe than other potential events. } \\
\text { Retained for further consideration. }\end{array}$ \\
\hline External Explosion & 2 & No potential for adverse consequences. \\
\hline External Fires & 2 & No potential for adverse consequences. \\
\hline External Floods & 3 & No potential for adverse consequences. \\
\hline Fog & 3 & No potential for adverse consequences. \\
\hline Forest/Grass Fire & 2 & Less severe than other potential events. \\
\hline Frost & 3 & No potential for adverse consequences. \\
\hline Hail & 2 & Less severe than other potential events. \\
\hline lce & 2 & Less severe than other potential events. \\
\hline $\begin{array}{l}\text { Industrial or Military Facility } \\
\text { Accident }\end{array}$ & 2 & Less severe than other potential events. \\
\hline Lightning Strikes & 3 & No potential for adverse consequences. \\
\hline Loss of Off-Site Power & 2 & Less severe than other potential events. \\
\hline Low Lake or River Water Level & 1,3 & $\begin{array}{l}\text { Not possible or plausible at this site. } \\
\text { No potential for adverse consequences. }\end{array}$ \\
\hline Meteor Strike & 1 & Not possible or plausible at this site. \\
\hline Missiles & 3 & No potential for adverse consequences. \\
\hline Operations in Nearby Facilities & 3 & No potential for adverse consequences. \\
\hline Pipeline Accidents & 2,3 & $\begin{array}{l}\text { Less severe than other potential events. } \\
\text { No potential for adverse consequences. }\end{array}$ \\
\hline River Diversions & 1,3 & $\begin{array}{l}\text { Not possible or plausible at this site. } \\
\text { No potential for adverse consequences. }\end{array}$ \\
\hline Sandstorms/Dust Storms & 3 & No potential for adverse consequences. \\
\hline Seiche & 1 & Not possible or plausible at this site. \\
\hline Snow & 2 & Less severe than other potential events. \\
\hline Straight Winds & 2 & Less severe than other potential events. \\
\hline Structural Interactions & 2 & Less severe than other potential events. \\
\hline Temperature Extremes & 3 & No potential for adverse consequences. \\
\hline Tornadoes & 2 & Less severe than other potential events. \\
\hline Transportation Accidents & 1 & Not possible or plausible at this site. \\
\hline Tsunami & 1 & Not possible or plausible at this site. \\
\hline Volcanic Activity & 1 & Not possible or plausible at this site. \\
\hline
\end{tabular}




\section{Aircraft Impacts}

The AHCF presents a very small target area for aircraft impact, and only a direct or a near-direct crash into a facility would damage the structures. Nevertheless, aircraft impact was retained for consideration in the PHA.

\section{Avalanches/Landslides}

Avalanches/landslides are not a concern due to the location of the facilities on gently sloping, flat terrain.

\section{Chemical/Toxic Gas Releases}

Release of chemical or toxic gas external to the structures (e.g., chlorine truck accident) would not result in any hazard to the contents of the facilities. Evacuation may be required in such an event, but temporarily abandoning operations results in no hazard to the facility's contents.

\section{Coastal Erosion}

The site is not subject to coastal erosion.

\section{Criticality Events}

All facilities in TA-V operate in accordance with SNL's Nuclear Criticality Safety Program (Philbin 1998). The ACRR and SPR are reactors, in which criticality occurs as a normal part of operations; however, both incorporate appropriate safety systems that control criticality. The Criticality Safety Assessment for the HCF has found that criticality is an incredible event (Mitchell and Romero 1999). Fissile materials brought into the GIF will not be in a configuration that will allow criticality, as will be determined by CSAs. Furthermore, TA-V personnel-evacuation procedures would protect AHCF personnel in the event of an external criticality event, as will be discussed in the FSAR. Therefore, external criticality events with the potential to affect the AHCF are incredible and are not considered further.

\section{$\underline{\text { Drought }}$}

Droughts are probable at the site, but there is no potential for adverse effects to the AHCF or its contents.

\section{Earthquake}

Seismic events would produce stresses and potential releases that are similar to or less severe than other events under consideration. The major AHCF building structures were designed and constructed according to the prevailing industry codes of the period. SNL has evaluated its building inventory for potential seismic risks and estimated the costs of 
mitigating the unacceptable seismic risks in those buildings in its response to Executive Order 12941 (SNL 1998). SNL ranked risk by failure consequence and building vulnerability. In addition, a seismic evaluation was performed on the AHCF and all other non-exempt buildings. They found the AHCF was not in the extremely high-risk group (SNL 1998). The hot cell was designed to withstand earthquake forces expected in Seismic Zone 2B without structural failure (Merrick 1999). Other portions of the AHCF confinement systems, such as the ventilation systems, are not specifically designed for earthquake loads. The highest consequence of an earthquake would be the release of radioactive material stored in the High Bay or hot cell; this accident is analyzed qualitatively in Appendix 3-C.

\section{External Explosion}

Blast pressures caused by the closest potential explosion to the facilities are not expected to damage the AHCF. The blast may disrupt the HEPA filters or cause loss of power to the ventilation system, but the radioactive material inventory on the filters is expected to be small and to have no potential to significantly impact the public or the environment.

\section{External Fires}

The only credible external fire threat is from range fires and from fires involving vehicles that may be close to the facilities. Range fires are considered separately under Forest/Grass Fires. Vehicle fires near the AHCF and fires in adjacent buildings would not result in any potential for adverse consequences due to the fire-resistant, concreteand-steel building construction.

\section{External Floods}

Localized water on the ground due to rainwater is possible near the AHCF, but general inundation of the facility is considered incredible for three reasons. TA-V is on a slight ridge that provides general drainage away from the facilities. The site is approximately $157 \mathrm{~m}$ above the Rio Grande riverbed and $14 \mathrm{~km}$ east of the main channel. A trench floor drain within the High Bay will divert any rainwater that does enter the AHCF, and the area of the floor surrounding silos (inside the hot cell and behind the permanent shield wall) will be raised above the general floor level of the AHCF. External flood is not plausible.

\section{$\underline{\text { Fog }}$}

Fog presents no hazard to the facilities or their contents.

\section{Forest/Grass Fire}

Because the site is located in an area of light desert vegetation, forest fires are not a concern. Although grass or range fires are possible at the site, a substantial distance of crushed rock or pavement exists as a firebreak between a grass or range fire and the 
facilities. This event is considered less severe than the other fire scenarios considered under External Fires.

Frost

Frost presents no hazard to the AHCF or its contents.

Hail

Hail is not a concern because of the structural characteristics of the facility. Furthermore, any potential effects of hail (i.e., roof collapse) are subsumed in the consideration of earthquakes.

$\underline{\text { Ice }}$

Ice loading is not a concern because of the structural characteristics of the facility. Furthermore, any potential effects of ice loading on the facilities (e.g., roof collapse) are subsumed in the consideration of earthquakes.

Industrial or Military Facility Accident

Because of the large restricted area around the AHCF and the remote location of the site, no external industrial accidents are credible causes of effects at the AHCF. The hazards associated with military accidents (i.e., explosions, aircraft crash) are considered separately in the discussions of Aircraft Impacts, Chemical/Toxic Releases, External Explosions, and Missiles. Accidents in adjacent facilities in TA-V, such as the reactor, could affect the AHCF slightly. The TA-V nuclear facilities have been designed to prevent accidents from releasing hazardous materials; thus, the effect of the adjacent facilities on the AHCF would likely be the same or less than external fires.

\section{Lightning Strikes}

Because of the lightning protection system, this event is not considered a credible threat to the AHCF or its contents.

\section{Loss of Off-Site Power}

Loss of off-site power would temporarily shut down the AHCF ventilation system. Thus, no releases to the environment would occur. Slow local contamination within limited areas of the AHCF might occur if power were not restored to the ventilation system for an extended period. 


\section{Low Lake or River Water Level}

This hazard is considered only if off-site water sources are required for safety-related cooling purposes. No such cooling requirements exist for the operations conducted at the AHCF. In any case, no lakes or rivers are present in TA-V, so this event is impossible.

\section{Meteor Strike}

The U.S. Nuclear Regulatory Commission has excluded meteor strikes as a credible threat to nuclear power plants (NRC 1987), so they are not considered further.

\section{$\underline{\text { Missiles }}$}

Missiles generated by straight winds or tornadoes do not require consideration in the evaluation - of the AHCF, which has safety-significant structures, systems, and components but no safety-class structures, systems, and components (DOE 1996a, 1996b). No rotating machinery located within the AHCF ventilation zones has the potential to generate missiles that could adversely affect the facilities or their contents. TA-III centrifuges are below grade and will not affect TA-V facilities such as the AHCF (Restrepo 1995).

\section{Operations in Nearby Facilities}

A number of facilities in TA-V conduct operations using hazardous materials. These facilities have analyzed the potential for and consequences of accidents on adjacent facilities in accordance with Chapter 13 of SNL's ES\&H Manual (SNL 1999). Except for issues associated with emergency evacuation, there is no potential for adverse consequences to the AHCF.

\section{Pipeline Accidents}

No pipelines present a hazard to the AHCF or its contents.

\section{$\underline{\text { River Diversions }}$}

This potential hazard is only relevant for facilities that depend on near-site rivers for safety-related cooling purposes. It is not possible at the AHCF, because no rivers are present.

\section{$\underline{\text { Sandstorms/Dust Storms }}$}

Sandstorms and dust storms do not represent a hazard to the AHCF or its contents. 


\section{$\underline{\text { Seiche }}$}

Seiches are not a concern for the AHCF, because no large shallow bodies of water are located near the site.

\section{Snow}

Snow loading is not a concern because of the structural characteristics of the AHCF. Furthermore, any potential effects of snow loading on the facilities (e.g., roof collapse) are subsumed in the consideration of earthquakes.

\section{$\underline{\text { Straight Winds }}$}

The structural characteristics of the AHCF make it impervious to all credible straight winds occurring at the site. In general, straight winds present less of a challenge to the facilities than earthquakes. Any effects of straight winds are therefore subsumed in the consideration of earthquakes.

\section{$\underline{\text { Structural Interactions }}$}

The exhaust stack for the AHCF is the only structure in the immediate vicinity that could cause an interaction by falling onto the AHCF in Building 6597. The stack itself is of lightweight construction. Due to the structural characteristics of the facilities and the construction of the hot cell, the potential for adjacent structural interaction causing damage that would release radioactive material to the environment is not credible. Fires in adjacent buildings are considered under external fires. Therefore, any effects of structural interaction are subsumed in the consideration of earthquakes.

Temperature Extremes

All facility construction and contents can withstand all expected temperature extremes without adverse safety implications.

\section{Tornadoes}

Tornadoes present less of a hazard to the AHCF than earthquakes or straight winds (LLNL 1984). Therefore, effects of tornadoes are subsumed in the consideration of earthquakes.

\section{Transportation Accidents}

Transportation accidents could occur only outside the TA-V complex, which encloses the AHCF. This external transportation will be conducted in accordance with the SNL ES\&H manual (SNL 1999). 
$\underline{\text { Tsunami }}$

Due to the inland location of the site, tsunamis are not relevant to the site.

Volcanic Activity

No potential for volcanic activity exists at or near the site.

References

(DOE 1996a)

U.S. Department of Energy, 1996, Natural Phenomena Hazards Performance Categorization for Structures, Systems, and Components, DOE-STD-1021-93, Change 1, U.S. Department of Energy, Washington, DC, January 1996.

(DOE 1996b)

(LLNL 1984)

U.S. Department of Energy, 1996, Natural Phenomena Hazards Design and Evaluation Criteria for Department of Energy Facilities, DOE-STD-1020-94, Change 1, U.S. Department of Energy, Washington, DC, January 1996.

Lawrence Livermore National Laboratory, 1984, Natural Phenomena Hazards Modeling Project: Extreme Wind/Tornado Hazard Models for Department of Energy Sites, UCRL-53526, Lawrence Livermore National Laboratory, Livermore, California, February 1984.

(Merrick 1999)

Merrick \& Company, 1999, “Advanced Design Criteria for the Auxiliary Hot Cell Facility Modifications, Building 6597," Final Review, Merrick \& Company, Albuquerque, NM, February 1, 1999.

(NRC 1987)

U.S. Nuclear Regulatory Commission, 1987, Evaluation of External Hazards to Nuclear Power Plants in the United States, NUREG/CR-5042, U.S. Nuclear Regulatory Commission, Washington, DC, December 1987.

(NRC 1983)

U.S. Nuclear Regulatory Commission, 1983, PRA Procedures Guide, NUREG/CR-2300, U.S. Nuclear Regulatory Commission, Washington, DC, January 1983.

(Philbin 1998)

Philbin, J. S., "Nuclear Criticality Safety," GN470072, Issue C, Sandia National Laboratories, Albuquerque, NM, January 28, 1998. 
(Restrepo 1995)

(SNL 1999)

(SNL 1998)
Restrepo, L. F., 1995, "Hot Cell Facility Safety Analysis Report," SAND94-2650, Sandia National Laboratories, Albuquerque, NM.

Sandia National Laboratories, "Environmental Safety and Health Manual," MN471001, Issue CE, Sandia National Laboratories, Albuquerque, NM, March 1, 1999.

Sandia National Laboratories, 1998, Supporting Documentation for Implementation of Executive Order 12941, Sandia National Laboratories, Albuquerque, NM, May 13, 1998.

(Mitchell and Romero 1999) G. W. Mitchell and D. J. Romero, 1999, Hot Cell Facility Criticality Safety Assessment for Storage of Medical Isotope Targets and Process Waste, Internal Memorandum Report, Sandia National Laboratories, Albuquerque, NM, March 1999. 
Internal Distribution

\begin{tabular}{|c|c|c|}
\hline & MS 0736 & Tom Blejwas, 6400 \\
\hline 1 & MS 0727 & Henry Duong, 6406 \\
\hline 1 & MS 1139 & Ken Reil, 6423 \\
\hline 1 & MS 1139 & John Garcia, 6423 \\
\hline 1 & MS 1145 & Ted Schmidt, 6430 \\
\hline 1 & MS 1145 & Bob Seale, 6430 \\
\hline 1 & MS 1145 & Bob Jefferson, 6430 \\
\hline 1 & MS 1142 & Jim Bryson, 6431 \\
\hline 1 & MS 1142 & Ken Boldt, 6431 \\
\hline 1 & MS 1141 & Norm Schwers, 6432 \\
\hline 3 & MS 1141 & AHCF Records Center, Dept. 6432 \\
\hline 2 & MS 1136 & Debby Oscar, 6432 \\
\hline 2 & MS 0651 & Sharon Walker, 6432 \\
\hline 1 & MS 1141 & Dennis A. Nelson, Jr., 6432 \\
\hline 1 & MS 1143 & Jeff Mahn, 6433 \\
\hline 1 & MS 1143 & Jeff Philbin, 6433 \\
\hline 1 & MS 1143 & Don Berry, 6433 \\
\hline 1 & MS 1141 & Susan Longley, 6441 \\
\hline 1 & MS 1141 & Marion McDonald, 6441 \\
\hline 1 & MS 1146 & Ron Lipinski, 6442 \\
\hline 1 & MS 1146 & Ted Luera, 6442 \\
\hline 1 & MS 1146 & Gary Harms, 6442 \\
\hline 1 & MS 1140 & Jim Rice, 6500 \\
\hline 1 & MS 0720 & Wu-Ching Cheng, 6804 \\
\hline 3 & MS 0716 & Regina Hunter, 6805 \\
\hline 1 & MS 1173 & Floyd Galegar, 7123 \\
\hline 1 & MS 1094 & Dann Ward, 7124 \\
\hline 1 & MS 1142 & Todd Culp, 7127 \\
\hline 1 & MS 1151 & Earl Conway, 7135 \\
\hline 1 & MS 1050 & Mike Street, 7135 \\
\hline 1 & MS 0932 & Paul Schlavin, 7931 \\
\hline 1 & MS 0321 & Bill Camp, 9200 \\
\hline 1 & MS 0873 & Al Bendure, 14302 \\
\hline 5 & MS 1396 & Liz Roybal, DOE/AL \\
\hline 1 & MS 9018 & Central Technical Files, 8940-2 \\
\hline 2 & MS 0899 & Technical Library, 4916 \\
\hline 1 & MS0612 & $\begin{array}{l}\text { Review \& Approval Desk, } 4912 \\
\text { For DOE/OSTI }\end{array}$ \\
\hline
\end{tabular}

